\title{
Camp Maxey III Archaeological Testing of 23 Prehistoric Sites, Lamar County, Texas
}

Richard B. Mahoney

Follow this and additional works at: https://scholarworks.sfasu.edu/ita

Part of the American Material Culture Commons, Archaeological Anthropology Commons, Environmental Studies Commons, Other American Studies Commons, Other Arts and Humanities Commons, Other History of Art, Architecture, and Archaeology Commons, and the United States History Commons

Tell us how this article helped you.

This Article is brought to you for free and open access by the Center for Regional Heritage Research at SFA ScholarWorks. It has been accepted for inclusion in Index of Texas Archaeology: Open Access Gray Literature from the Lone Star State by an authorized editor of SFA ScholarWorks. For more information, please contact cdsscholarworks@sfasu.edu. 


\section{Camp Maxey III Archaeological Testing of 23 Prehistoric Sites, Lamar County,}

Texas

\section{Creative Commons License}

\section{(c) (1) (8)}

This work is licensed under a Creative Commons Attribution-NonCommercial 4.0 International License 


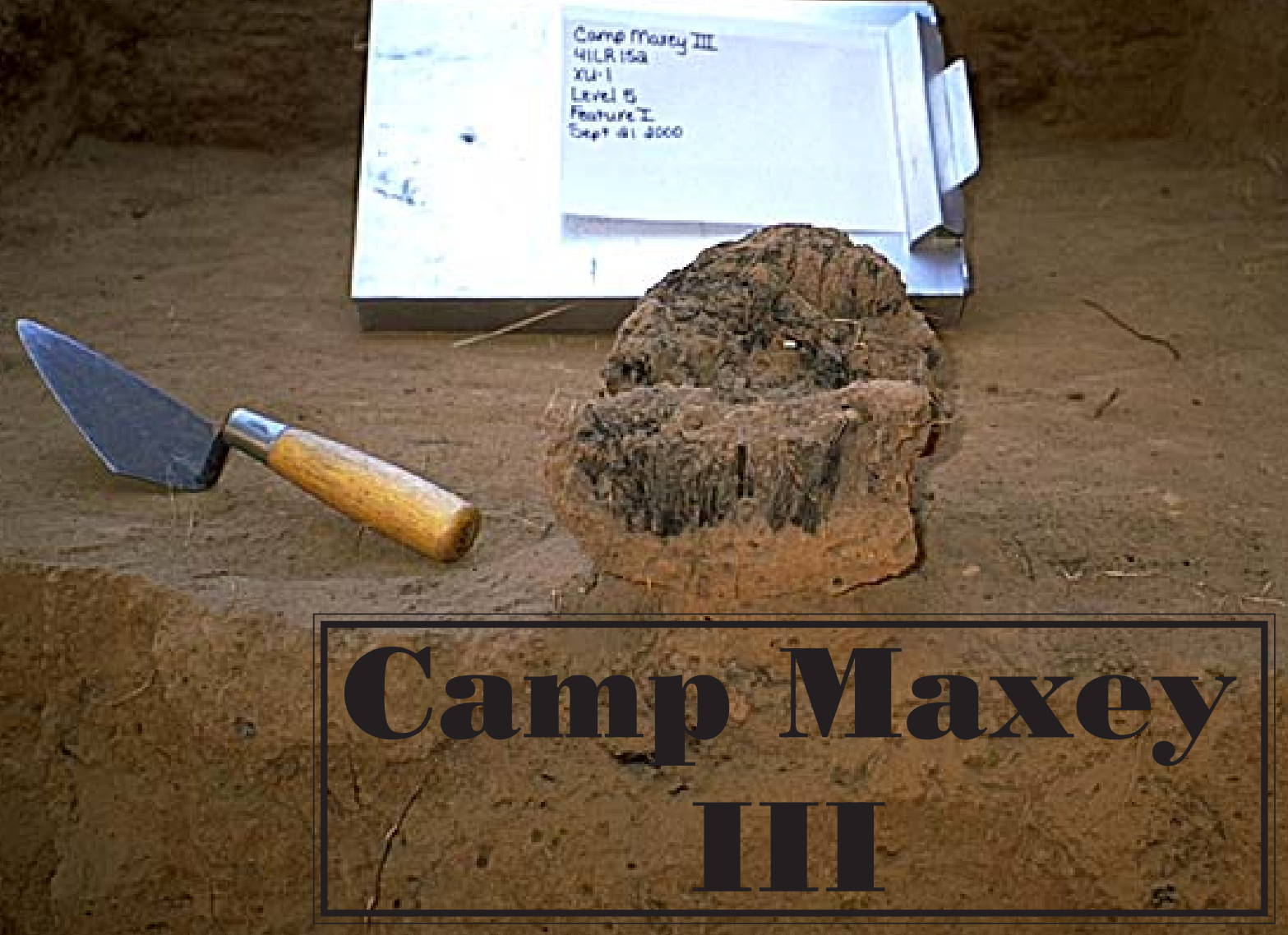

\section{Archaeological Testing of 23 Prehistoric Sites, Lamar County, Texas}

by

Richard B. Mahoney

with contributions by

Corey A. Crawford, Raymond P. Mauldin, Lee C. Nordt, Timothy K. Perttula, and Sylvia Reyna

Center for Archaeological Research The University of Texas at San Antonio Archaeological Survey Report, No. 314 2001

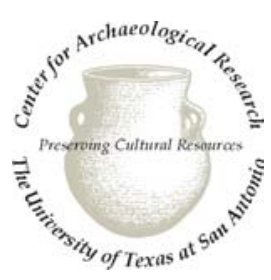




\title{
Camp Maxey III \\ Archaeological Testing of 23 Prehistoric Sites, Lamar County, Texas
}

\author{
by \\ Richard B. Mahoney \\ with contributions by \\ Corey A. Crawford, Raymond P. Mauldin, \\ Lee C. Nordt, Timothy K. Perttula, and Sylvia Reyna
}

Texas Antiquities Committee Permit No. 2180

\section{Steve A. Tomka \\ Principal Investigator}

Prepared for:

Adjutant General's Department of Texas Directorate of Facilities and Engineering Environmental Branch Austin, Texas
Prepared by:

Center for Archaeological Research The University of Texas at San Antonio Archaeological Survey Report, No. 314 San Antonio, Texas

Ccopyright 2001 
The following information is provided in accordance with the General Rules of Practice and Procedure, Chapter 41.11 (Investigative Reports), Texas Antiquities Committee:

1. Type of investigation: Testing

2. Project name: Camp Maxey III, Selected Sites (23) Testing

3. County: Lamar

4. Principal investigator: Steve A. Tomka

5. Name and location of sponsoring agency: Texas Army National Guard, Cultural Resources, P.O. Box 5218, Austin, TX 78763-5218

6. Texas Antiquities Permit No.: 2180

7. Published by the Center for Archaeological Research, The University of Texas at San Antonio, 6900 N. Loop 1604 W., San Antonio, Texas 78249-0658, 2001

A list of publications offered by the Center for Archaeological Research is available. Call (210) 458-4378; write to the Center for Archaeological Research, The University of Texas at San Antonio, 6900 N. Loop 1604 W., San Antonio, Texas 78249-0658; e-mail to car@lonestar.utsa.edu; or visit CAR's web site at http://car.utsa.edu. 


\begin{abstract}
From August 2000 through January 2001, The Center for Archaeological Research, The University of Texas at San Antonio conducted National Register of Historic Places eligibility testing for 23 prehistoric archaeological sites (41LR152, 41LR153, 41LR155, 41LR156, 41LR157, 41LR158, 41LR160, 41LR163, 41LR164, 41LR168, 41LR170, 41LR186, 41LR187, 41LR202, 41LR204, 41LR207, 41LR208, 41LR212, 41LR260, 41LR266, 41LR268, 41LR285, and 41LR286) located within the Camp Maxey training facility in north Lamar County, Texas, under contract with Texas Army National Guard. The investigations were conducted under Texas Antiquities Permit Number 2180. The Phase II testing fieldwork consisted of excavation of backhoe trenches, shovel tests, and excavation/test units across the sites to investigate significant cultural deposits encountered during the previous survey phases. In concert with the archaeological field investigations, the following special analyses and studies were performed to aid the determination of site integrity and eligibility: geoarchaeology, radiocarbon, lithic, native ceramic, and magnetic sediment susceptibility. The synthesis of these analyses has provided adequate data to determine temporal integrity and recommendation of National Register eligibility for 41LR152, 41LR164, 41LR186, and 41LR187. Further cultural resources investigations in the form of Phase III data recovery excavations are thus recommended for these sites prior to proposed development.
\end{abstract}

Conversely, due to lack of significance criteria: sites 41LR153, 41LR155, 41LR156, 41LR157, 41LR158, 41LR160, 41LR163, 41LR168, 41LR170, 41LR202, 41LR204, 41LR207, 41LR208, 41LR212, 41LR260, 41LR266, 41LR268, 41LR285, and 41LR286 are recommended as ineligible for inclusion in the National Register of Historic Places and require no further cultural resource investigations. 


\section{Camp Maxey III: \\ Archaeological Testing of 23 Prehistoric Sites, Lamar County, Texas}

\section{Contents}

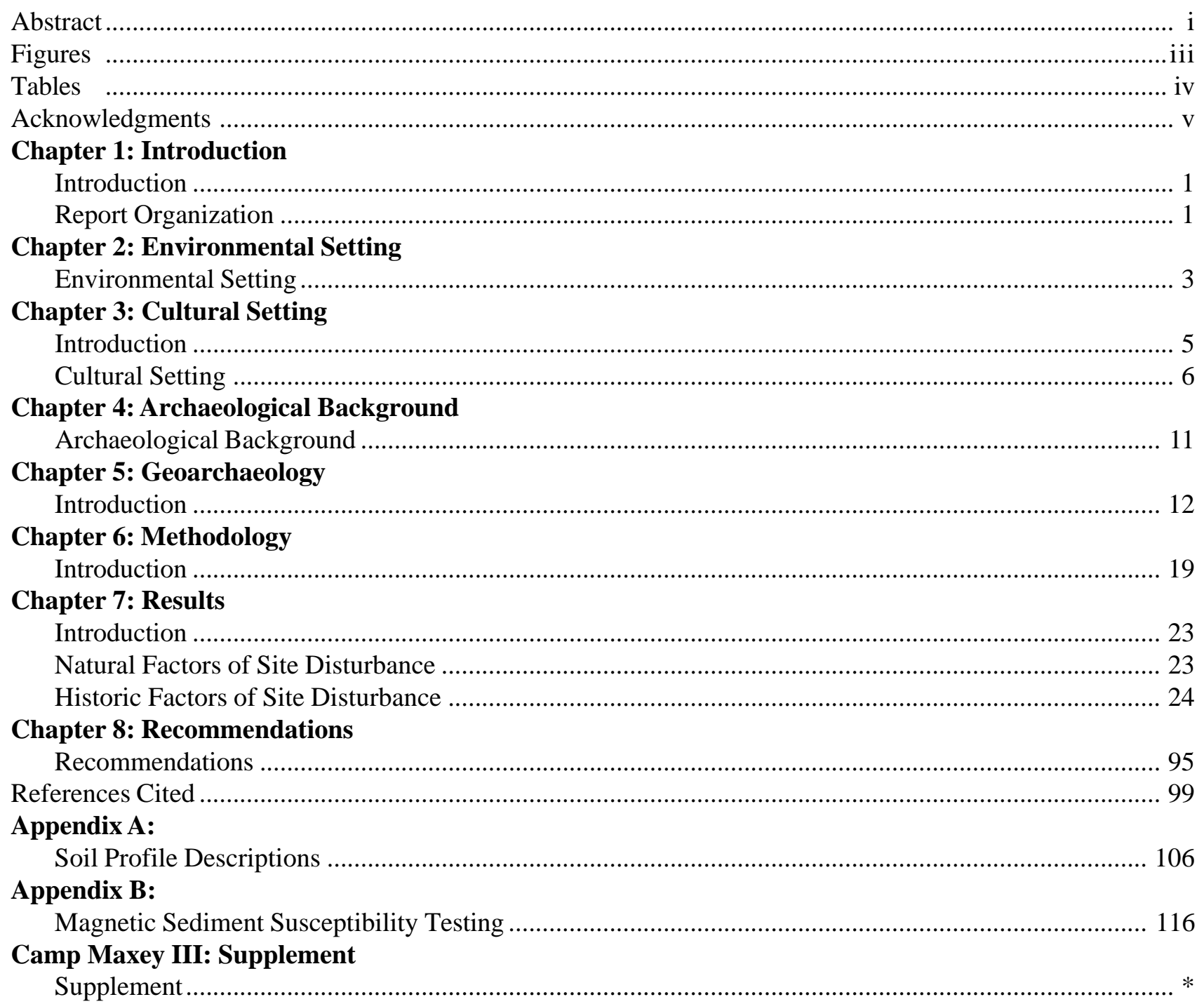




\section{Figures}

Figure 1. General location of Camp Maxey in Lamar County, northeast Texas............................................ 2

Figure 2. Project area in relationship to Natural regions of Texas. ............................................................. 3

Figure 3. The Trans-Mississippi South (adapted from Schambach 1998) ................................................... 6

Figure 4. Comparative cultural chronologies and paleoenvironmental conditions. ..................................... 7

Figure 5. Geomorphic surfaces exhibited within the Camp Maxey project area. ..........................................* *

Figure 6. Schematic cross section of geomorphic surfaces within the Camp Maxey project area.................. 13

Figure 7. Diagrammatic cross sections of nine backhoe trenches, southwest portion. ................................. 14

Figure 8. Diagrammatic cross sections of eight backhoe trenches, western portion. ................................... 15

Figure 9. Diagrammatic cross sections of five backhoe trenches, north-central portion............................... 16

Figure 10. Location of archaeological sites within the Camp Maxey training facility................................ *

Figure 11. Location of historic roads and structures within the pre-military project area. ............................ *

Figure 12. World War II-era military training areas within the project area............................................... *

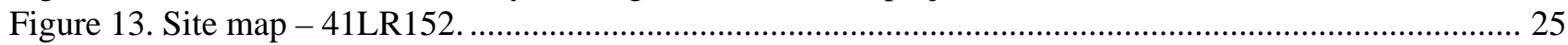

Figure 14. Intact native ceramic vessel recovered from Level 7 of XU-2, 41LR152 _............................ 26

Figure 15. Remnant of structural post photographed in Level 5 of XU-1, 41LR152 ................................ 27

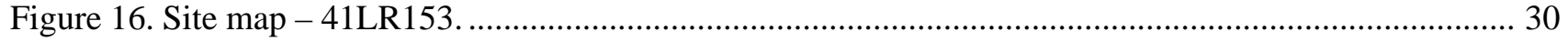

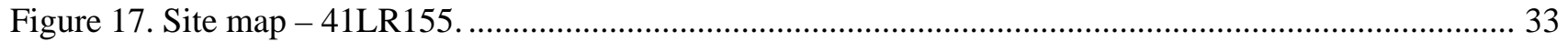

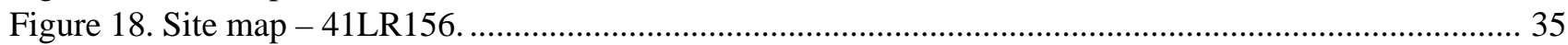

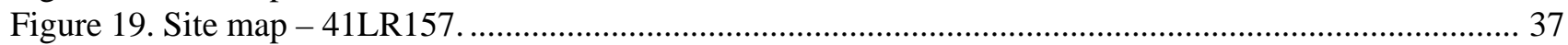

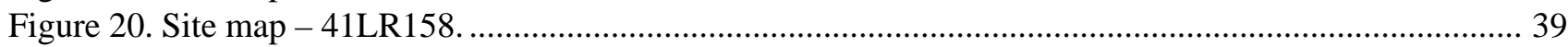

Figure 21. Dalton dart point recovered at ground surface $~ 150$ m east of 41LR158. ................................ 40

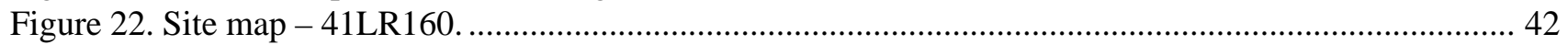

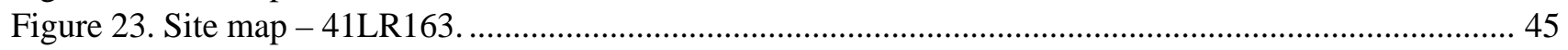

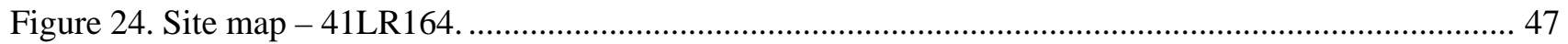

Figure 25. Representative bifaces recovered during the testing phase from various sites. .......................... 48

Figure 26. Plan view of 41LR164, Excavation Unit 1, Level 4, Feature 1............................................... 49

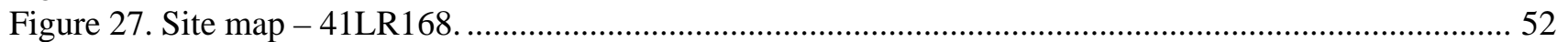

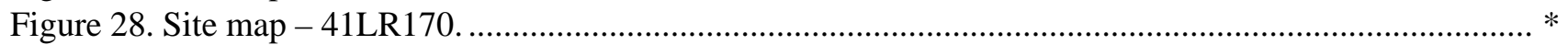

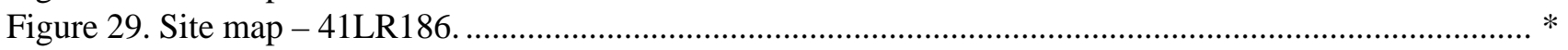

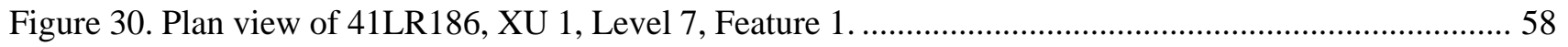

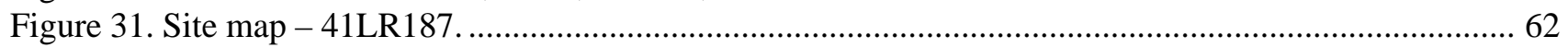

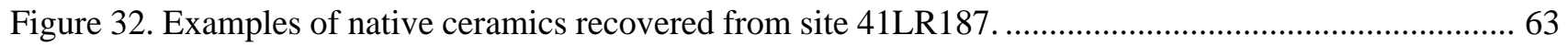

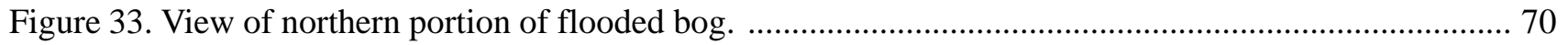

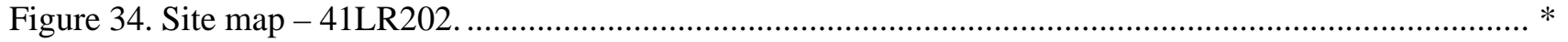

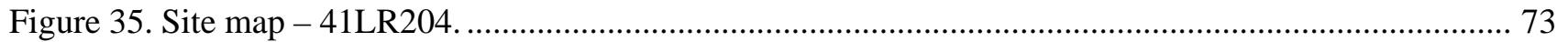

Figure 36. Wall Profile of 41LR204, XU 2, North Wall ............................................................................... 74

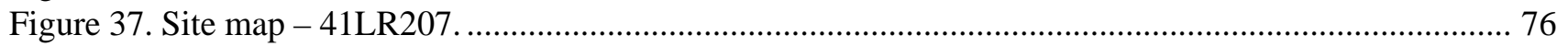

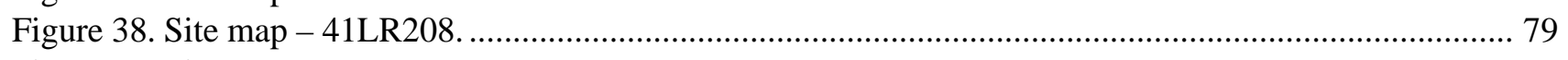

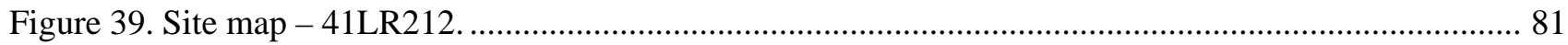

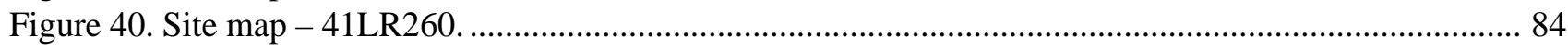

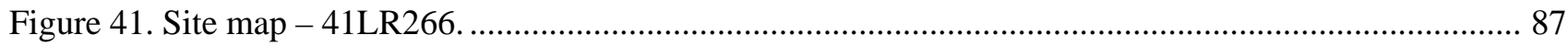

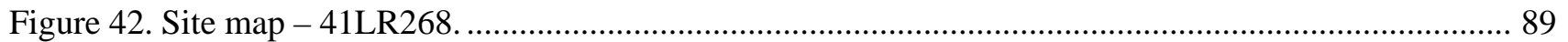

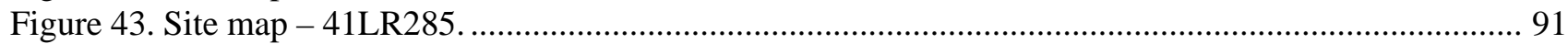

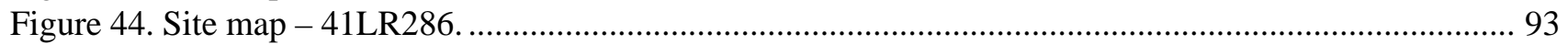

* Figures located in supplement. 


\section{Tables}

Table 1. Radiometric results from Camp Maxey III samples ...................................................................... 27

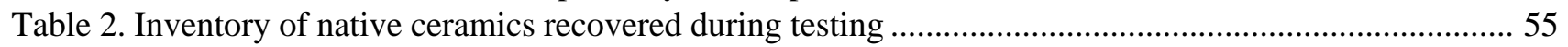

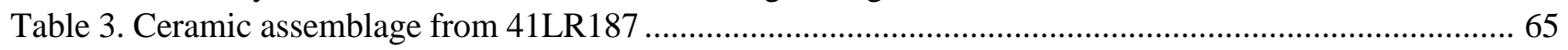

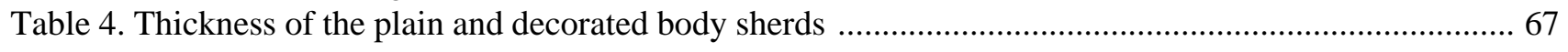

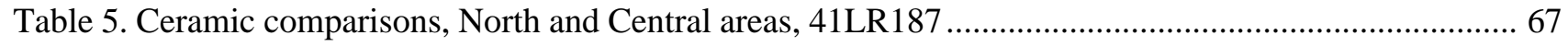

Table 6. Depositional integrity and eligibility status of the 23 previously recorded prehistoric sites ............. 95

Table B-1. Magnetic sediment susceptibility data for a variety of substances ........................................ 117

Table B-2: Presence/absence of cultural material and mass specific sediment susceptibility ..................... 117

Table B-3. Sediment susceptibility data for Camp Maxey testing ............................................................. 118

\section{Camp Maxey III: Supplement}

Figure 5. Geomorphic surfaces exhibited within the Camp Maxey project area. ........................................ *

Figure 10. Location of archaeological sites within the Camp Maxey training facility................................. *

Figure 11. Location of historic roads and structures within the pre-military project area. ............................ *

Figure 12. World War II-era military training areas within the project area.............................................. *

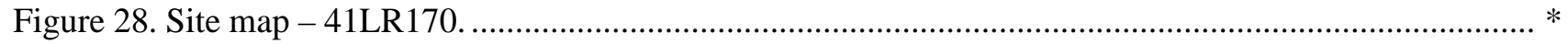

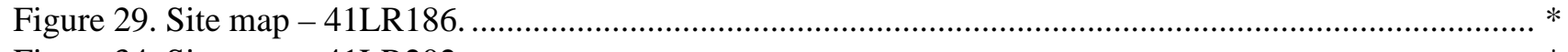

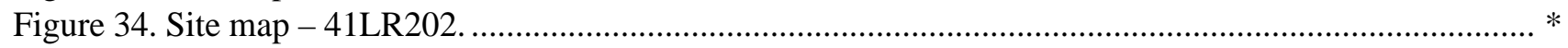

* Figures located in supplement. 


\section{Acknowledgments}

The staff at the Center for Archaeological Research (CAR) wish to thank the Camp Maxey Facility Manager, Sgt. Linda Surber, and Sgt. Norman Nicholson for their support during the fieldwork. They allowed us access to the facility and shared their considerable knowledge of the camp's history. Shellie Prewitt, Cultural Resources Manager at Camp Mabry, and the staff at the Adjutant General's office in Austin, provided logistical support and facilitated the timely completion of the fieldwork. Also, we greatly appreciate Ms. Prewitt's dedication to scientific research, her interest in Caddo archaeology, and the preservation of cultural resources on the facility.

We would like to thank the owner and staff at the Victorian Inn for their hospitality. Their willingness to work with us when room reservations were constantly changing, is greatly appreciated. Similarly, Bob and Brian, backhoe operators from J.D. Mickel Construction, deserve a great deal of thanks for their hard work in the loose sands of Camp Maxey.

The crew of the Maxey III project, led by Richard Mahoney, consisted of: Don Broussard, Cory Broehm, Jennifer C. Henley, Richard Jones, Ruth Mathews, Rick Robinson, Lisa Shaddox, and C. Scott Speal. Dave Nickels and Anthony Lyle, project archaeologists during two previous field seasons of work at Camp Maxey, were instrumental in introducing the new project archaeologists and crew to the subtleties of archaeology on the facility. All of these individuals deserve many thanks for their hard work and dedication to proper archaeological methods and techniques. Many thanks also are due to the CAR staff, including Raymond Mauldin, Bruce Moses, Richard Young, Marybeth Tomka, Maryanne King, Johanna Hunziker and Jennifer Logan for their hard work in bringing the project to fruition in the form of this report. The numerous site and project maps, the accuracy of the tables and data, and the overall outstanding quality of the report are due to their hard work. Finally, none of it could have been possible without the help of the large number of laboratory staff that washed, cataloged, and prepared for curation the collection of artifacts from the project. The consultants that have contributed time, energy, and effort in the form of special analyses and studies to this report also

deserve many thanks. Timothy Perttula analyzed the ceramics and Dr. Lee Nordt and Corey Crawford contributed research to understanding the geomorphology of the project area. 



\section{Chapter 1: Introduction}

\section{Introduction}

From August 2000 through January 2001, the Center for Archaeological Research (CAR), The University of Texas at San Antonio (UTSA) under contract with Texas Army National Guard (TXARNG) conducted National Register of Historic Places (NRHP) testing at selected sites within the Camp Maxey training facility in north Lamar County, Texas (Figure 1). The purpose of the current investigations is to assess, through excavation of backhoe trenches, shovel tests, and excavation units, the NRHP eligibility of 23 prehistoric archaeological sites determined potentially eligible during previous survey efforts (Lyle et al. 2001; Nickels et al. 1998). The Texas Antiquities Permit Number (2180) originally assigned to the most recent CAR survey project (Lyle et al. 2001) is retained for the current testing phase by an extension of contractual obligations through TXARNG, with Dr. Steve A. Tomka continuing to serve as Principal Investigator. Concurrent with the archaeological investigations, Corey A. Crawford of Baylor University conducted geomorphological studies.

\section{Report Organization}

The Camp Maxey project has been expanded to include both survey and testing efforts under the original contract. Edition 1, Camp Maxey II, A 5,000 Acre Cultural Resource Survey of Camp Maxey, Lamar County, Texas (Lyle et al. 2001) reports on the survey portion of the project. The current document, Edition II, reports on the testing of the 23 prehistoric sites. While each edition serves as a stand-alone document, background chapters such as the Cultural Setting, the Environmental Setting, and the Archaeological Background in this edition will not be replicated in as great detail. The interested researcher is referred to Lyle et al. (2001) for a more in-depth discussion of these aspects of the Camp Maxey training facility.
This report is composed of eight chapters with two appendices. Following this introductory chapter, the Environmental Setting chapter will discuss the general physical environment encountered within the project area. The third chapter, Cultural Setting, provides a brief overview of the cultural prehistory and history of the region. Chapter 4, Archaeological Background, presents previous archaeological investigations within the region and an overview of previously recorded sites. Chapter 5 discusses the geomorphology and geoarchaeological interpretations of the project area. The sixth chapter, Methodology, describes, in detail, the field and laboratory methodologies employed during the investigations, special analyses, and curatorial requirements. Chapter 7 , Results, will discuss the results from the field and laboratory investigations on a site-by-site basis. The final chapter, Recommendations, presents recommendations for NRHP eligibility and for further work (where warranted).

The two appendices provide supporting data for the analyses and site assessments. Appendix A provides detailed soil and stratigraphic descriptions and Appendix B presents the results of soil susceptibility analyses. Sensitive site maps and Camp Maxey facility maps not included in the text are located in a separate supplement which has been published with this report. 


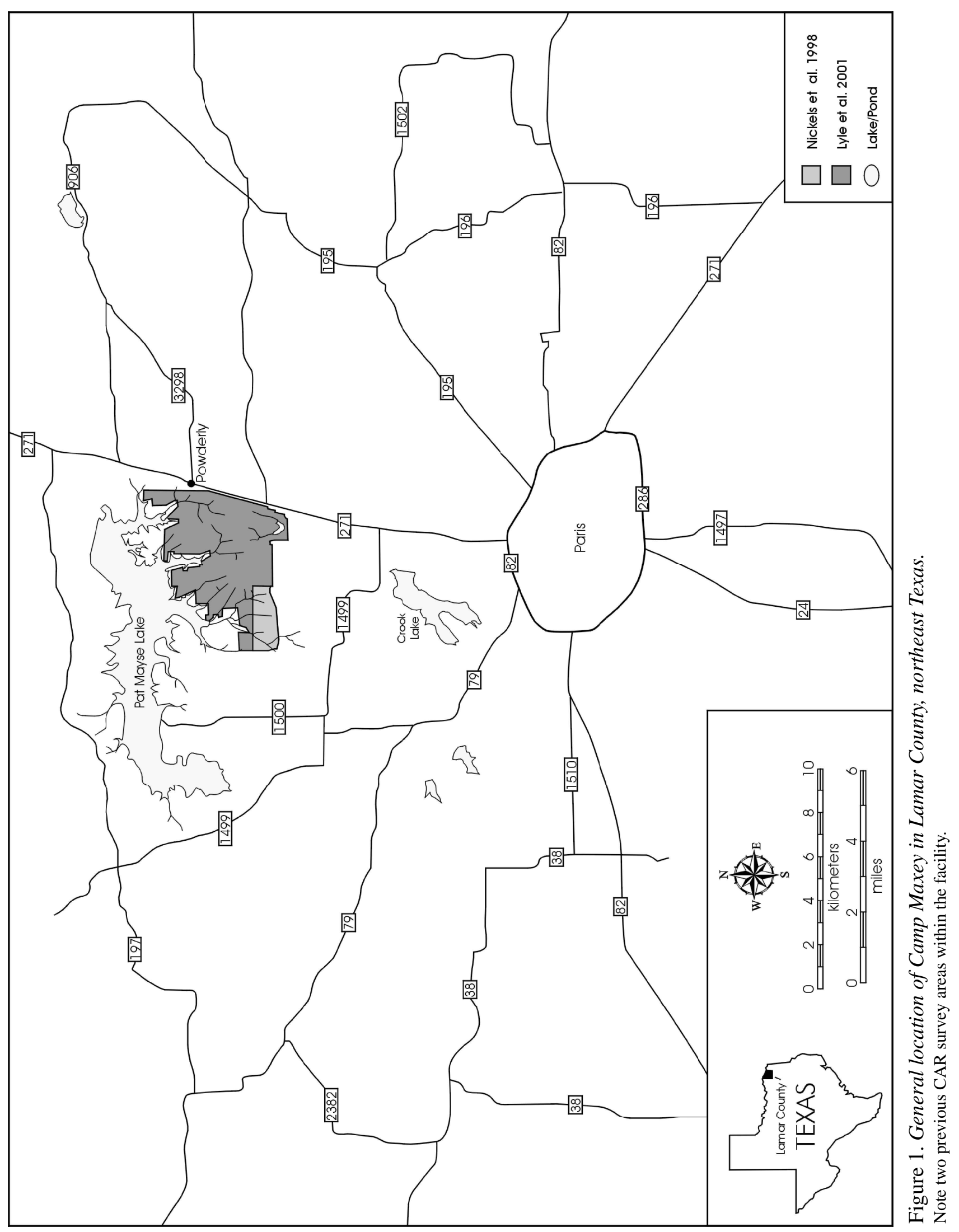




\section{Chapter 2: Environmental Setting}

Camp Maxey is located in the north-central portion of Lamar County, approximately $9.7 \mathrm{~km}(6 \mathrm{mi})$ north of the city of Paris, Texas. The project area is bound to the north by Pat Mayse Reservoir; to the east by US HWY 271; to the south by Gate Two County Road; and to the west by unimproved pasturage. In its current state, the training facility occupies approximately 6,400 ac $(2,590$ ha), far less than the original 70,000 ac $(28,329$ ha) allocated by the federal government in 1942.
The extant, remnant portion of Camp Maxey is wholly contained within the Post Oak Savannah vegetation region (Figure 2), with a relative diversity of flora. Oak woodlands atop upland sandy and loamy soils predominate throughout the project area, with intermittent prairies of little bluestem comprising a majority of the remainder of the project area. Persimmon and winged sumac seem to occur in greatest densities along the border of the prairies and intersecting riparian zones of intermittent tributaries and

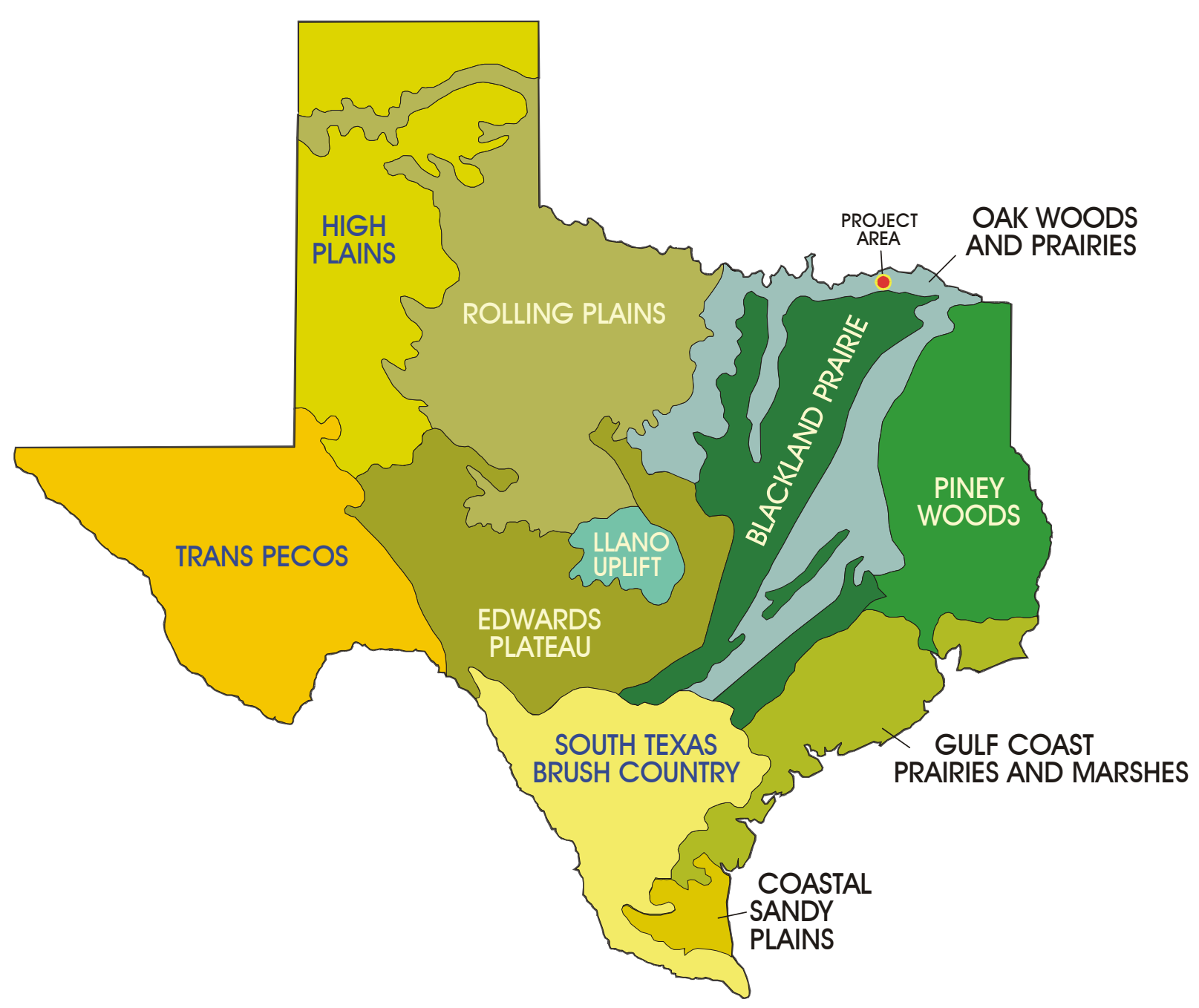

Figure 2. Project area in relationship to Natural regions of Texas. 
perennial streams. A seasonal wetland forms the centrum of site 41LR202 (see Chapter 7: Results), and would be classified as a Red Ash/American Elm wetland community. Riparian zones of water oak/elm border the numerous second and third order tributaries that dissect the training facility draining into Pat Mayse Reservoir.

The reservoir was constructed from Sanders Creek, a tributary of the Red River, in 1967 following authorization from the Flood Control Act of 1962; Project Document HD 71, 88th Congress, 1st Session. According to the U.S. Army Corps of Engineers (COE) station data, the reservoir occupies 7,680 ac $(3,108$ ha) at the top of the flood control pool (460.5 ft above mean sea level [AMSL]) with an approximate 182,940 ac-ft ( 225-billion liter) capacity. Construction of the reservoir subsumed roughly ten percent of the original acreage of the training facility including some of the more intensive, live-round munitions activity areas.

According to recent, Soil Conservation Service (SCS) soil survey maps of the project area, Camp Maxey is located within the Whakana-Porum series of moderate to well-drained upland loamy soils (Ressel 1979). Within this series occur several soil map units as defined by the 1974 soil survey. Approximately 61 percent of the tested sites at Camp Maxey occur on Whakana-Porum complex or Whakana fine sandy loams. These soils generally exhibit slow to moderate permeability with moderate to rapid runoff, providing severe water erosion potential (Ressel 1979:31). The remainder of the sites occur on Woodtell loams (17 percent), Annona loams (13 percent), and Lassiter silt loams ( 9 percent).

Numerous natural springs and seeps were encountered within the bounds of the training facility. While historic wells in the vicinity have probably reduced the resources of the springs and seeps, prehistoric occupation proximity to these natural features would have been preferred. Magnitude ranges from slow, barely noticeable seeps to active, swift-flowing springs of cold, clear water.
Landform elevations range from $460 \mathrm{ft}(140 \mathrm{~m})$ to $560 \mathrm{ft}(171 \mathrm{~m})$ AMsL throughout the project area. Roughly 87 percent of the tested sites occur within the $480 \mathrm{ft}(146 \mathrm{~m})$ to $510 \mathrm{ft}(156 \mathrm{~m})$ AMSL elevation range, and only one site occurs above $520 \mathrm{ft}$ $(159 \mathrm{~m})$ AMSL. The majority of these sites occupy finger ridges adjacent moderate to very steep ravines. This distributional pattern is most likely associated with proximity to potable water in the form of seeps, springs, or intermittent streams. 


\section{Chapter 3: Cultural Setting}

\section{Introduction}

Geographically, Camp Maxey is situated in the extreme northeast corner of Texas (see Figure 1), immediately north of the juncture of the Post Oak Savannah and Blackland Prairie vegetation subregions (see Figure 2). The general region of the project area is bordered to the west by the Southern Plains, to the north by the Ouchita province, to the southwest by the Edwards Plateau, and to the south by the West Gulf Coastal Plain. The proximity to these various ecotones and physiographic provinces provides for the influence of various adaptation patterns, patterns of mobility, and/or external cultural influences.

Accordingly, a regional chronology for such an area would need to address this multifarious geographic aspect. To address this issue, Schambach (1998:7) proposes the establishment of a new natural area that would be situated east of the Great Plains and west of the Lower Mississippi Valley, entitled the Trans-Mississippi South (Figure 3). Schambach proposes the northern boundary as the Missouri River and the southern boundary as the Gulf Coastal Marshes, the South Texas Brush Country, and the Edwards Plateau. In justification of the proposed extreme northern boundary, Schambach cites the continuity of pre-Caddoan artifact assemblages across this vast region, specifically lithic technology and early ceramic types and varieties ascribed to Woodland cultures (Schambach 1998:8).

While it is generally accepted that Archaic cultures were less sedentary than Late Prehistoric (or here Caddoan) cultures, it seems unlikely that a single Archaic culture or series of cultures would consistently span this immense area. Rather, natural geographic boundaries such as the Ouchita or Ozark mountain ranges would seem a more likely northern extent to Schambach's natural region. Specifically, dart point typologies differ greatly across these regions, and the general similarities in pre-Caddoan ceramic types and varieties are not solely conclusive evidence for the combination of vastly different environmental settings during the Woodland or preceding Archaic and Paleoindian periods.

One possibility for the extreme northern extent of the Missouri River espoused by Schambach, however, would be expansive trade networks evident at Spiro Mounds in Oklahoma and suggested at the Sanders Site (41LR2) in Lamar County, Texas (Jackson et al. 2000). Here, Schambach (2000) suggests that the inhabitants of the Sanders Site were a satellite trade group affiliated with the Spiroans, trafficking the abundant Osage Orange of Lamar County with Plains and Mississippian goods through the trade route of Spiro. While not unequivocally representative of the Caddo or Caddoan culture, the presence of these traders in northeast Texas suggests high mobility of peoples and, more so, their goods across vast areas. Similarities in pottery styles across Schambach's Trans-Mississippi South account for the trade network during Woodland and Caddoan periods, however, the evidence for this network during the Archaic period is lacking.

As such, a closer approximation to the generally accepted Western Gulf Coastal Plain through the Ouchita Mountains (Perttula 1992:7-9) Caddoan area would probably serve as an adequate, and probably more accurate, delineation of the various regions for discussion here and may be proposed as a Southern Caddoan subregion within the Trans-Mississippi South. The southern boundary, as suggested by Schambach, is appropriately provided by the Blackland Prairie, Post Oak Savannah, and Piney Woods vegetation subregions of Texas. The eastern boundary is afforded by the Southeastern Evergreen Forest of the Lower Mississippi Valley, while the Southern Plains form the western boundary. The northern boundary, however, would more reasonably be placed at the Arkansas River or, more conservatively, along the boundary of the Ouchita province.

A temporal chronology has been specifically developed for the northeastern Texas region (Perttula 1999). While that chronology will be used here as a basis for 


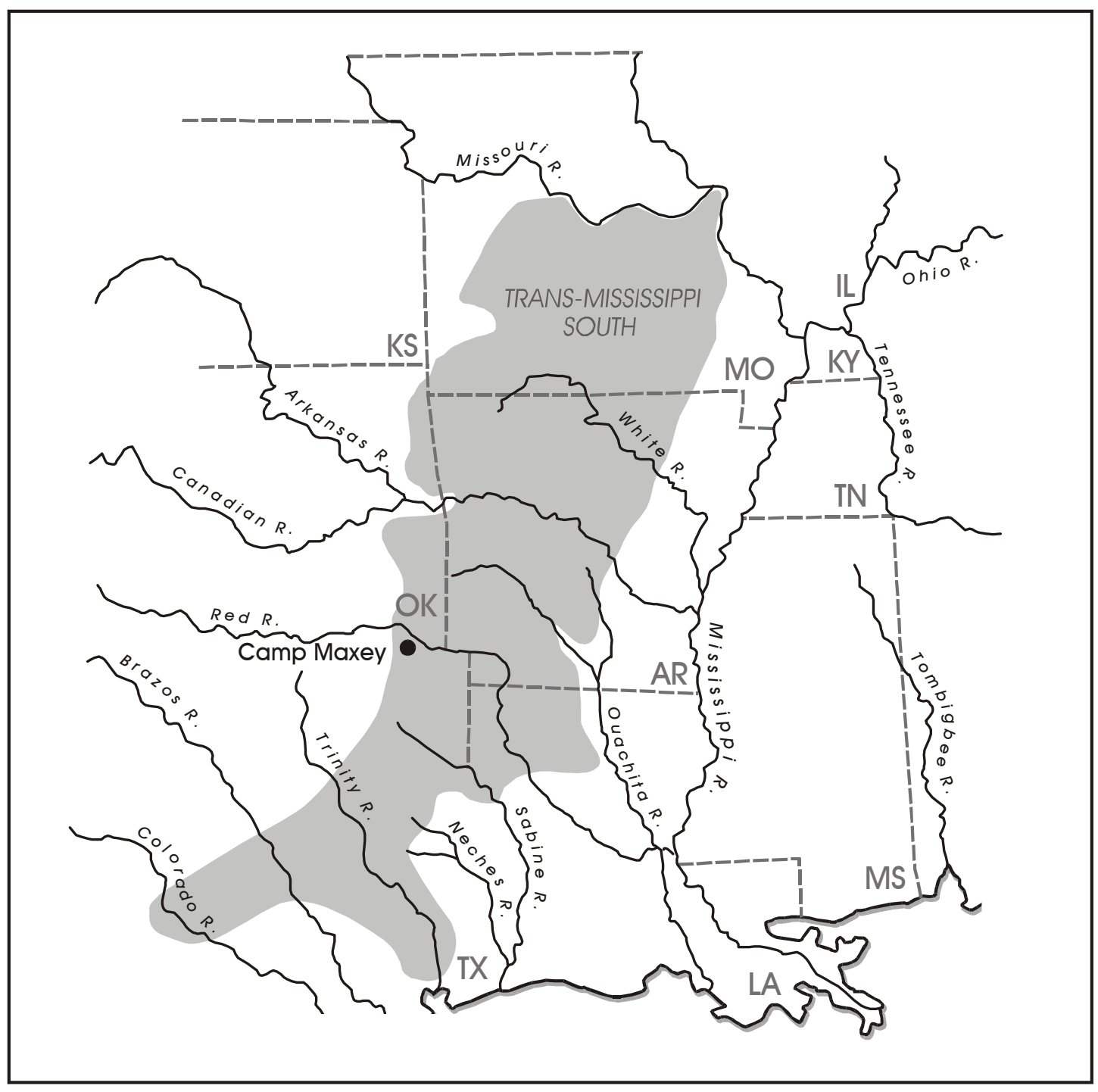

Figure 3. The Trans-Mississippi South (adapted from Schambach 1998).

our temporal chronology, Figure 4 presents various "regional" chronologies and paleoenvironmental conditions from southeast Oklahoma, southwest Arkansas, northwest Louisiana, and northeast Texas that demonstrate considerable variation in their division of the Prehistoric era. All four chronologies are deemed germane to the current project area as all fall within the proposed subregion of the Trans-Mississippi South natural area. Thus, an attempt will be made to incorporate each regional chronology in an attempt to form a clearer picture of the prehistory of the Camp Maxey training facility.

\section{Cultural Setting}

\section{Paleoindian}

The Paleoindian period is conceptually that era in prehistory wherein humans first entered the New World, an event that happened sometime during the latter part of the Pleistocene geologic epoch. Due to the frequent location of isolated finds of Paleo era projectile points (such as the Dalton dart point recovered east of 


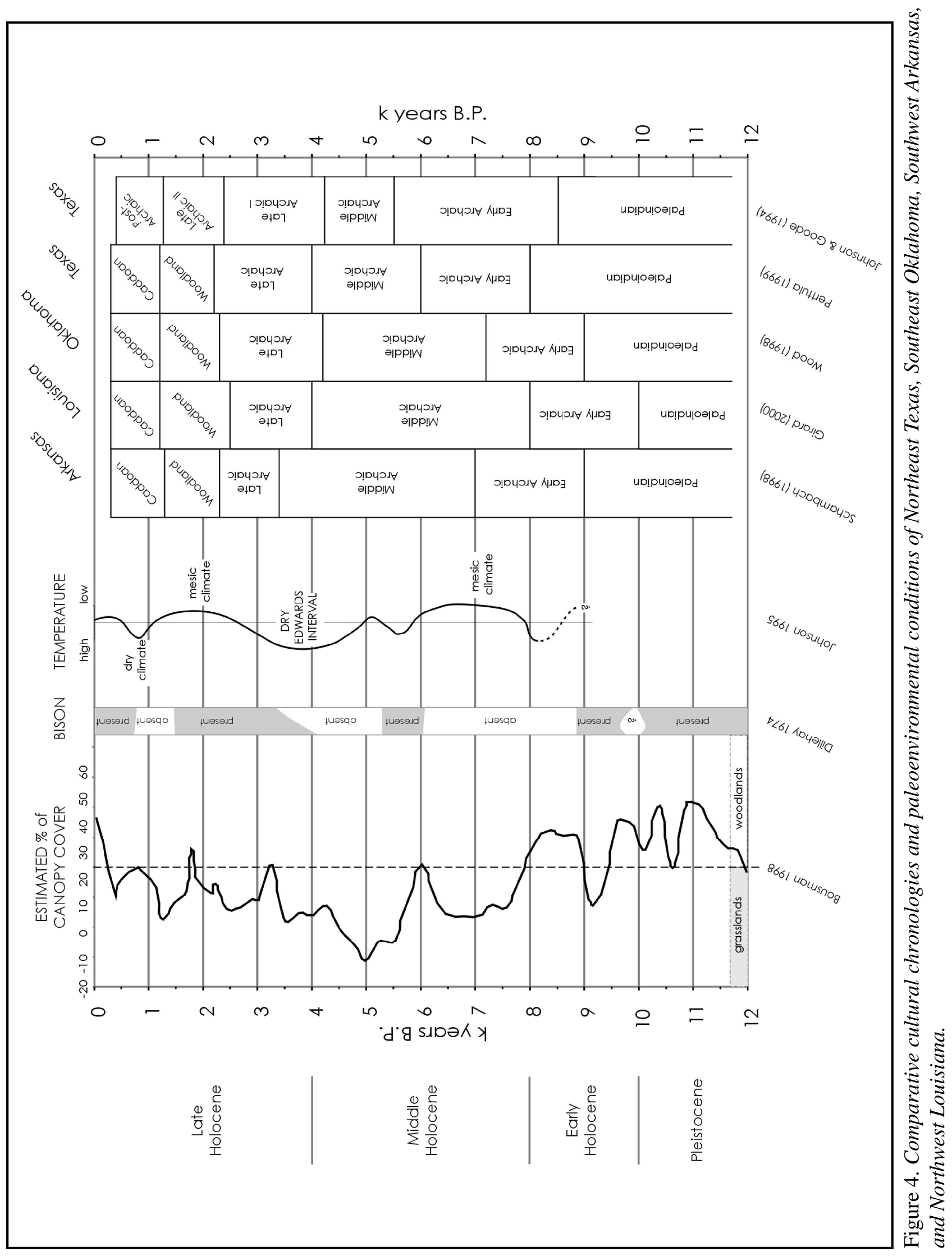


41LR158 [see Chapter 7: Results]) and the infrequent encounter of dense occupational features, researchers infer that these peoples were highly mobile, nomadic hunters and opportunistic gatherers. It is probable that the cultures of this era were specialized exploiters of the dwindling population of the now extinct megafauna that once roamed the North American continent.

With some variation, the Paleoindian period for this region is generally agreed to have begun approximately 12,000 years ago and terminated roughly 9,000 to 8,000 years ago sometime during the Early Holocene climatic interval (Johnson and Goode 1994; Perttula 1999; Schambach 1998; Wood 1998). However, Girard (2000:7) argues that the Paleoindian period for Northwest Louisiana occurs from 12,000 BP until 10,000 BP. The termination for this period, relative to conventional Texas chronologies (however slightly varied they may be) is quite premature, and Girard qualifies this discrepancy due to the fact that "archaeologists in Texas do not routinely calibrate radiocarbon dates" (2000:8). Granted, the primary reference Girard cites (Collins 1995) does not use calibrated dates; however, the periods of Collin's chronology do not differ markedly from those espoused by Johnson and Goode (1994), which are based upon calibrated dates utilizing the methodology of Stuvier and Reimer (1993).

Johnson and Goode (1994:19) do provide a convenient, nevertheless provocative qualification for this discrepancy in the temporal chronologies. The proximity of the Conly site (16BI19), as well as others of the Great Bend region of the Red River (e.g., Cliff et al. 1990; Kelley et al. 1988) with cultures of the Mississippian cultures may have been subjected to an Eastern cultural influence. Specifically, as Johnson and Goode (1994:19) clarify, southeastern cultures were more directly impacted by the end of the Pleistocene and, possibly by the extinction of the megafauna. Thus these cultural adaptations changed more rapidly to a culture more recognizable as that of the Archaic era.

Regardless the chronology of choice, the Paleoindian period is divided technologically into early and late phases. The early phase is characterized by the presence of primarily fluted projectile points (i.e., Clovis and Folsom) produced, primarily, from non-local materials. The exotic stone tools recovered from these early sites further suggest a high-mobility culture. The late phase of the Paleoindian period is regionally characterized by dart points, such as San Patrice and Dalton, consisting primarily of local materials (Schambach 1998). The presence of woodworking tools, such as the Dalton adze, in association with these new variant dart points suggests a slightly more sedentary culture than its predecessor.

\section{Early Archaic}

The Archaic era represents the following ca. 6,000 to 6,500 years of prehistory for this region and is subdivided into three separate periods: Early, Middle, and Late. Environmentally, this era commences just before the onset of the Middle Holocene geologic epoch, a time of "oscillating" conditions beginning at a moderate climate, trending toward a dry extreme, and returning to moderate conditions throughout the entirety of the era (Collins 1995:383; Johnson 1995). Culturally, the development of the Archaic within this region and, more specifically within the Plains margin proper, may have been attributable to Late Paleoindian plainsmen exploiting the woodland-prairie margin and interacting with woodland cultures during times of drought (Johnson 1989).

Early Archaic manifestations within the region include the apparent onset of sedentary subsistence indicated by the diversity of recovered artifact assemblages at numerous sites (e.g., Girard 2000; Wyckoff 1984;). Specifically, woodworking tools, such as adzes and wedges, become more common, as well as abraders and scrapers. The Conly site in northwestern Louisiana exhibited excellent preservation of faunal remains including mussel shell, bone, snail, and crawfish exoskeletons (Girard 2000:63). Additionally, Girard cites the presence of burned rock, grinding stones, pounding tools, an axe, various bifaces, and bone tools as further indicators of a more diversified pattern of subsistence (2000:63).

\section{Middle Archaic}

The relatively brief Middle Archaic period represents the final years of the Middle Holocene and can be viewed as a transitional time for the prehistoric peoples 
of the region. During the early part of this period, bison are present along the bordering plains and prairie regions after a nearly three millennia hiatus (Dillehay 1974). Their appearance is short-lived, however, and by approximately 5200 вр bison once again disappear from the faunal assemblage of the Southern Plains and adjoining prairie margin. The continuance and massive proliferation of relative sedentism and/or specific exploitation of localized natural resources is evidenced by the continued occupation and re-occupation of preferred landforms (e.g. Girard 2000:8). Johnson and Goode also point to the specialization of targeting specific natural resources, possibly xerophytic plants (1994:28). These characteristics in response to an increasingly drier environment (c.f. Bousman 1998; Johnson 1995) would form the basis for the transformation in the overall stylistic tradition to that of the Late Archaic.

\section{Late Archaic}

The Late Archaic period represents the final three millennia of the Archaic Era, from approximately 4200 BP to 1200 BP (Johnson and Goode 1994:29), and roughly coincides with the commencement of the Late Holocene. Within northeast Texas, the Woodland, preCaddoan culture introduces a new aspect to this generally accepted time of pre-ceramic, dart and atlatl using inhabitants of the state. Crude ceramics alongside smaller dart points typical of the Late Archaic period are diagnostic of this Woodland period.

Adaptation to a relatively dry climate with low precipitation and high temperatures appears to mark the beginning of the period, with bison reappearing in the faunal assemblage following an over one thousand year hiatus (Dillehay 1974). Despite these xeric conditions, human population seems to have increased within the region (Prewitt 1985). Adaptation to this changing environment is best shown in Prewitt's (1981) discussion of the Uvalde and Twin Sisters Phases for central Texas. During this time, burned rock middens and similar burned rock scatters are abandoned. Diagnostics of this period are usually encountered stratigraphically above the underlying middens and scatters.
Floodplain-focused adaptation during this time is evident in various sites adjacent to the region (Girard 2000:9; Mahoney and Tomka 2001). Environmental changes can be cited as determinate factors in settlement patterns during this time. Specifically, temporary stabilization of stream bank terraces can be attributable to settlement patterns. During and prior to this period, streams exhibited various stages of aggradation and stabilization. These dynamic changes are evidenced in the extant location of occupation sites in relation to streams and their current location topographically. The further analysis of this proximate location can be instrumental in determining the spatial relationship between site locations relative to the former meanders of the associated stream.

The commencement of the Late Archaic I phase relative to the project area is characterized by a generally xeric environment probably correlative with the Dry Edwards Interval to the west and southwest. Palynological evidence from the Boriak bog (Lee County, Texas) and the Weakly bog (Leon County, Texas) reveals relatively low arboreal canopy cover; indicating a predominant grassland environment for these adjoining regions (Bousman 1998:Figure 7). Johnson and Goode (1994:34-35) propose that, due to the xeric conditions experienced by the peoples of the Late Archaic I period, burned rock middens proliferate for the processing of semi-succulents. Additionally, the period is further defined by the projectile-point styles of the Bulverde, Pedernales, Marshall, Montell, and Castroville (Johnson and Goode 1994:Figure 2).

Johnson and Goode suggest eastern (United States) religious influences, manifest in the form of various burial practices, as one of the primary indicators of the Late Archaic II phase (1994:37). The continuum of the trend toward a mesic environment can also be attributable to this period change. While a definitive date cannot be placed upon the abandonment of burned rock middens, Johnson and Goode note that these feature types are generally associated with the Late Archaic I phase, and the absence thereof denotes the beginning of the Late Archaic II phase (1994). Typical projectile-point styles of this phase include, in progressive order, Marcos, Ensor, Frio, Darl, and Figueroa (Johnson and Goode 1994:Figure 2). 


\section{Woodland}

Unique to characteristic Caddoan areas in northeast Texas, the Woodland period encompasses the latter 1,300 years of the traditionally accepted Late Archaic period in other Texas temporal chronologies (25001200 BP). Within the Caddoan area, this period basically subsumes the Late Archaic II phase, described above. This pre-Caddoan, ceramic culture is distinctive of northeast Texas archaeology. Artifact assemblages consist primarily of later, smaller Gary dart points to early expanding stem arrow points and early, sandy paste ware ceramics. As stated above, most ceramic cultures within Texas are associated with the Late Prehistoric. Here, Archaic era dart points are encountered alongside ceramic vessels and associated sherds. This coincidence provides evidence for a continuum of native technology. While the advent of ceramics in concert with the occurrence of the bow and arrow in the remainder of the state signifies the onset of the Late Prehistoric period, the advent of ceramics alone indicates the Woodland period.

\section{Caddoan}

Transition from the Late Archaic, and more specifically from the Woodland, to the Caddoan is arguably accepted to occur with the advancement in technology from hunting techniques utilizing the atlatl and dart to utilization of the bow and arrow alongside the beginning of horticultural and, later, agricultural groups. Additionally, the occurrence of Caddoan-specific ceramic vessels generally denotes this change of periods. The Caddoan period is here defined as the timeframe of approximately 1200 BP until European contact, roughly $300 \mathrm{BP}$ within this region.

Explicit subdivisions of the Caddoan era have been established in recent years to better define the technological advancement of these peoples (e.g., Story 1990). The following timeline, adapted from Kenmotsu and Perttula (1993), provides a general synopsis of horticultural and agricultural advancements:

\section{Formative Caddoan (A.D. 800-1000)}

Onset of horticulture, but hunting and gathering still play an important role in subsistence.
Early Caddoan (A.D. 1000-1200)

Formal horticulture to the beginnings of agriculture. Hunting continues, but gathering becomes less important.

Middle Caddoan (A.D. 1200-1400)

Intensive agriculture and hunting predominate subsistence. Foraging does not appear to be a pivotal activity in the subsistence base.

\section{Late Caddoan (A.D. 1400-1680)}

Intensive agriculture, specifically maize, predominates the diet as evidenced in skeletal pathologies. Less effort seems to be placed on hunting.

In the central Texas region, bordering to the west and southwest of the Caddoan area, Prewitt identifies the initial succeeding Late Prehistoric phase as the Austin Phase, occurring from the termination of the Late Archaic II until approximately 650 BP (Prewitt 1981:Figure 3). This phase would generally be coeval with the Formative and Early Caddoan cultures. Aside from the aforementioned changes in technology, Prewitt ascribes only a slight increase in the dependence upon hunting as a means of subsistence and a marked increase in the occurrence of "true cemeteries" as an indicator of period change (1981:74).

The succeeding central Texas Late Prehistoric phase, the relatively short-lived Toyah phase, as defined by Prewitt (1981), is characterized by the "dramatic" shift in subsistence from hunter-gatherer to that of an economy based primarily on hunting. This phase would generally be coeval with the Middle and Late Caddoan cultures. Based upon data from Dillehay (1974), bison once again appear in the faunal assemblage of archaeological sites within central Texas. An intermediate shift to a generally dry, mesic environment is attributed to this influx of ungulate dependence (Johnson 1995). The material culture of this time-period appears to reflect subsistence based upon the procurement of bison in the form of various stone tools utilized for bison procurement and processing, such as Edwards, Perdiz, and Scallorn arrow points, along with various scrapers and other stone tools. 


\section{Chapter 4: Archaeological Background}

Professional archaeological investigations began in the Lamar County region with the 1931 University of Texas excavations at the Sanders Farm Site (41LR2) in the far northwestern portion of Lamar County (Jackson et al. 2000). Later that year, the University also conducted limited test excavations at 41LR1, the Womack Site (Harris et al. 1965). The remainder of the earlier sites, primarily mound and/or burial sites, recorded by R. K. Harris throughout the mid-twentieth century were subsequently assigned current trinomials (41LR3-41LR9).

The impending construction of Pat Mayse Reservoir on Sanders Creek necessitated archaeological surveys that resulted in the recordation of an additional 23 trinomials in Lamar County. Sites 41LR10 through 41LR21 were recorded during the Texas Archeological Salvage Project (TASP) immediately prior to commencement of construction on March 9, 1965 (Shafer 1965). In 1967, the Archeological Salvage Project of Southern Methodist University conducted limited test excavations of sites recommended by Shafer for more intensive cultural resource investigation (1965:38) and also conducted further survey, locating an additional eleven sites (Lorrain and Hoffrichter 1968).

Various other universities and state agencies conducted survey and testing in Lamar County over the following three decades. Southern Methodist University conducted two phases of cultural resource surveys in Lamar County in the early 1970s. Both phases focused on the proposed Big Pine Lake project in the eastern portion of Lamar County and western portion of Red River County. A total of 53 archaeological sites were recorded in Lamar County during the two phases of survey (Hyatt and Mosca 1972). In the late 1970s and early 1980s, the Texas Department of Water Resources (now, Texas Water Development Board) recorded six sites during reconnaissance work for utility easements in the city of Reno, west of Paris (Fox 1979, 1981). North Texas State University (now, University of North Texas), Institute of Applied Sciences conducted various surveys in Lamar County throughout the late 1970s and 1980s. These surveys were primarily for the development of utility easements (e.g., Perttula and Nathan 1988) and yielded the discovery of 37 additional sites. The State Department of Highways and Public Transportation (now, Texas Department of Transportation) conducted Phase II testing on two prehistoric sites east and south of the project area (41LR58 and 41LR92), respectively, concluding neither eligible for inclusion in the National Register of Historic Places (Luke 1978; Young 1984). Additionally, the Texas Archeological Society (TAS) conducted a part of their 1991 field school at the Ray Site (41LR135), located along Nolan Creek, east of the current project area.

Prior to CAR's various survey and testing efforts, only limited cultural resource investigations have been conducted within the confines of the training facility. Survey for a utility easement resulted in the recordation of two historic (41LR138 and 41LR139), and one disturbed prehistoric lithic quarry site (41LR137) within Camp Maxey (Corbin 1992). During the 1990s, the Adjutant General's Department of Texas (AGD) conducted three limited pedestrian surveys within the facility, locating four historic sites (41LR14541LR148) that predate the military era (AGD 1993, 1997; Sullo and Stringer 1998). 


\section{Chapter 5: Geoarchaeology}

\section{Corey A. Crawford and Lee C. Nordt}

\section{Introduction}

There were two geoarchaeological objectives within the Camp Maxey project area in northern Lamar County:

1. To establish a general geomorphic and stratigraphic framework within the previously recorded archaeological sites; and

2. To assess the surface and buried preservation potentials within these archaeological sites.

\section{Methods}

Twenty-two backhoe trenches (BHT) were excavated to depths of 1 to $2 \mathrm{~m}$ to describe the soils and stratigraphy (Figure 5 in supplement). Soil-stratigraphic descriptions were written following the procedures of the Soil Survey Division Staff (1993). Soil-stratigraphic columns of all twenty-two backhoe trenches were constructed to illustrate the morphological and stratigraphic variation of geological units throughout the study area.

\section{Study Area}

The Camp Maxey project area is situated on approximately 6,000 acres in north-central Lamar County. The project area is dissected by a tributary network consisting of low-order creeks that flow northward towards Sanders Creek and, eventually, into the Red River. Sanders Creek was dammed by the U.S. Army Corps of Engineers (COE) to form Pat Mayse Reservoir to the north of the current project area (see Figure 5 in supplement).

Two Cretaceous geological formations are mapped within the project area (Barnes 1979). The Eagle Ford Shale (Kef) underlies the majority of the study area.
This formation is comprised of gray clays and shales that grade into channel sands to the east near the Lamar-Red River County line. The southern portion of the project area is underlain by the Bonham Formation (Kbo), a marl and clay unit with increasing sand content towards the east.

Approximately $1 \mathrm{~km}$ north of the project area, an area of Qt4 is mapped (Barnes 1979). This formation is a terrace of the Red River situated 110 to 120 feet (34-37 m) above the floodplain, at an elevation of 510 to 520 feet (156-159 m). Several areas east and west of the project area are mapped as Qt5 at elevations of about 560 feet $(171 \mathrm{~m})$. A majority of the project area lies within the elevations of these Red River terraces, and thus may contain erosional and depositional remnants of Pleistocene alluvial deposits of the ancestral Red River.

\section{Geomorphology and Soils}

Nordt and Bousman (1998) defined three geomorphic surfaces containing erosional and depositional elements within the project area (Figure 6). Within the current project area, two of these geomorphic surfaces, $\mathrm{G} 2$ and $\mathrm{G} 3$ are identified and discussed.

The oldest geomorphic surface (G2) is mapped between surface elevations of 500 to $540 \mathrm{ft}$ (Figure 5 [supplement] and Figure 6). The Freestone Series coincides with this G2 surface. The Bonham Formation underlies the Freestone Series (Ressel 1979). The Freestone Series is classified as a fine-loamy, siliceous, thermic Glossaquic Paleudalf. The Whakana Series coincides with this geomorphic surface. Eagle Ford Shale underlies this series. The Whakana Series is classified as a fine-loamy, mixed, thermic Glossaquic Paleudalf. Both the Freestone and Whakana are characterized by thick A-E-Bt horizons with fine sandy loam to loam $\mathrm{A}$ and $\mathrm{E}$ horizons and clay loam to clay Bt horizons. 


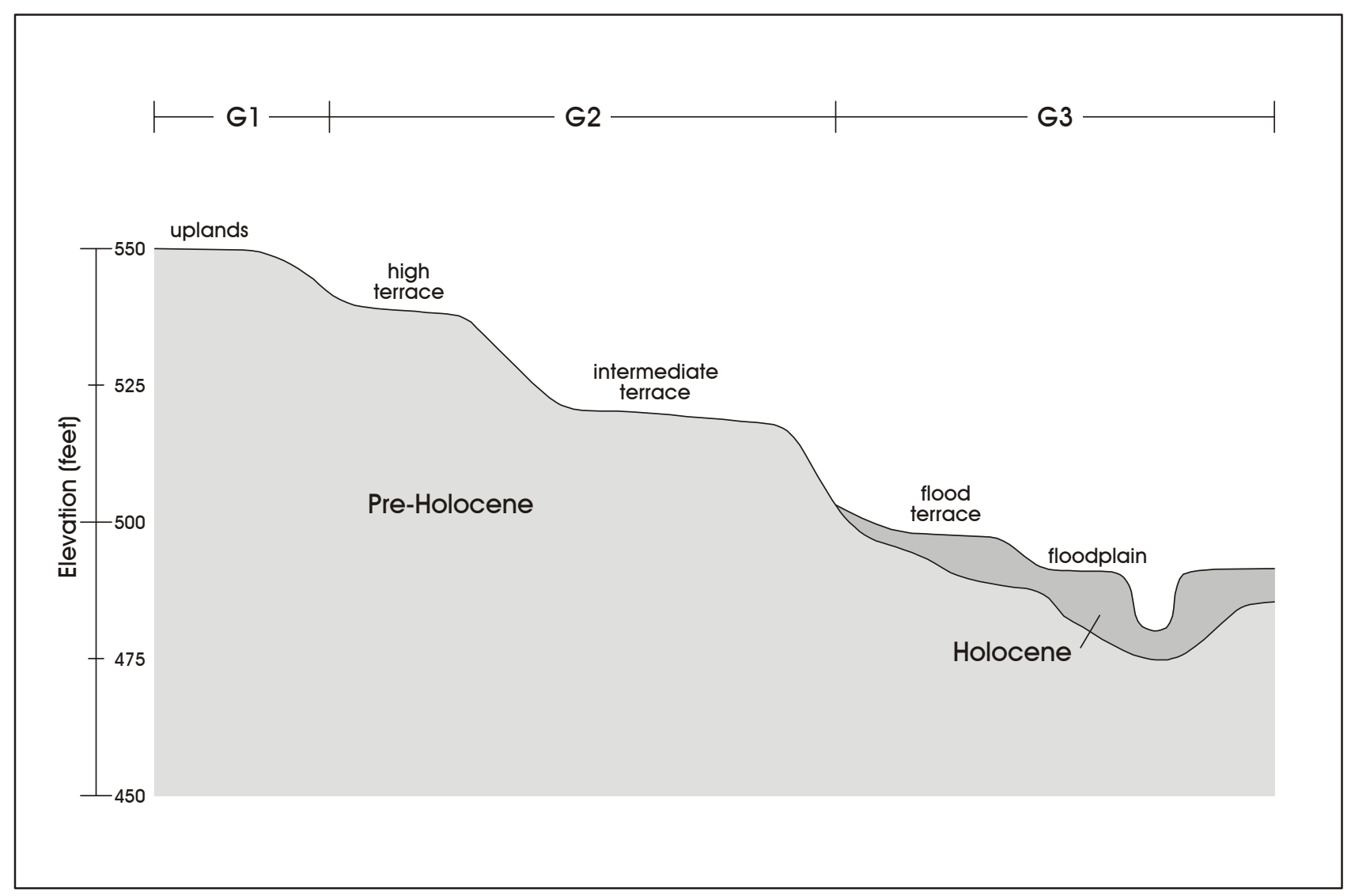

Figure 6. Schematic cross section of geomorphic surfaces within the Camp Maxey project area.

The G2 geomorphic surface is also within the range of the Qt4 terrace of the Red River, 10 to 40 feet above the modern entrenched stream valleys. Depositional elements of this surface are associated with several bogs, and include the terrace throughout the study area. This surface also contains erosional elements on steeper slopes. Based on stratigraphic position and degree of soil development, this geomorphic surface is most likely Pleistocene in age.

The youngest geomorphic surface (G3) typically occurs below elevations of $500 \mathrm{ft}$ (Figure 5 [supplement] and Figure 6). This surface includes depositional elements such as the modern floodplains (frequently flooded surfaces) and flood terraces (intermittently flooded surfaces), and erosional elements on steep hillslopes grading into flood terraces and floodplains. The Whakana Series is associated with the flood terraces and toeslopes that grade into flood terraces in the northern portion of the study area. These surfaces are most likely the remnants of Qt4 terraces of the Red River. Soils in the southern portion of the project area on the G3 surface are mapped as the Lassiter Series (fine-silty, mixed, non-acid, thermic Aquic Udifluvents) and Annona Series (fine, montmorillonitic, thermic Vertic Paleudalfs) in the modern floodplains. The Lassiter Series is frequently flooded and is characterized by a shallow A-C profile sequence commonly underlain by a buried soil between depths of 50 and 100 $\mathrm{cm}$ (Ressel 1979). Texture ranges from silt loam to silty clay loam. The Annona Series is characterized by an AE-Bt-Btss profile sequence with textures ranging from loam in the A and $\mathrm{E}$ horizons to clay in the Bt and Btss horizons. The Annona Series is described as a clayey upland or terrace soil, suggesting the modern tributary valley associated with this soil is comprised of strath terraces, upon which Holocene lateral accretion sediments have accumulated (Waters 1992). 


\section{Stratigraphy}

\section{Pre-Holocene}

A Pre-Holocene unit was identified in the following backhoe trenches: BHTs 1, 2, 3, 5 through 19, 21, and 22 (Figures 7-9) (Appendix A). This unit is characterized as a gray clay (Bt, Btg, Btv) with reddish iron masses and plinthite overlain by a sandy mantle (A, $\mathrm{E}, \mathrm{Bw}$ ) associated with the high terraces and intermediate terraces of the Red River (BHTs 7, 10, 13, 16, and 21) (Figures 7-9). No evidence of eolian sedimentation was observed within the G2 geomorphic surface. Due to elevated position and age of these high and intermediate terraces, the Pre-Holocene soil profiles are most likely pedogenically formed from the weathering of the Eagle Ford Shale and the Bonham Formation.
In some intermediate terrace positions within the G2 and G3 geomorphic surfaces the Pre-Holocene unit is comprised of remnant younger Pleistocene terraces of the ancestral Red River (BHTs 2, 11, 14, 15, 17, 18, and 22) (Figures 7-9, and Appendix A). This unit is typically characterized as a brown sandy loam, sandy clay loam, or clay with black iron-manganese nodules and red iron masses and clay films (Bt, Btc, C) overlain by a sandy mantle (A, E). In BHT 18 a Pre-Holocene sand unit underlies the sandy mantle. This sand unit is most likely a sand bar deposited by the ancestral Red River (Figure 9). Again, due to elevated position and age of these higher river terrace landforms, the Pre-Holocene soil profiles are most likely pedogenically formed from the weathering of Pleistocene ancestral Red River terraces.

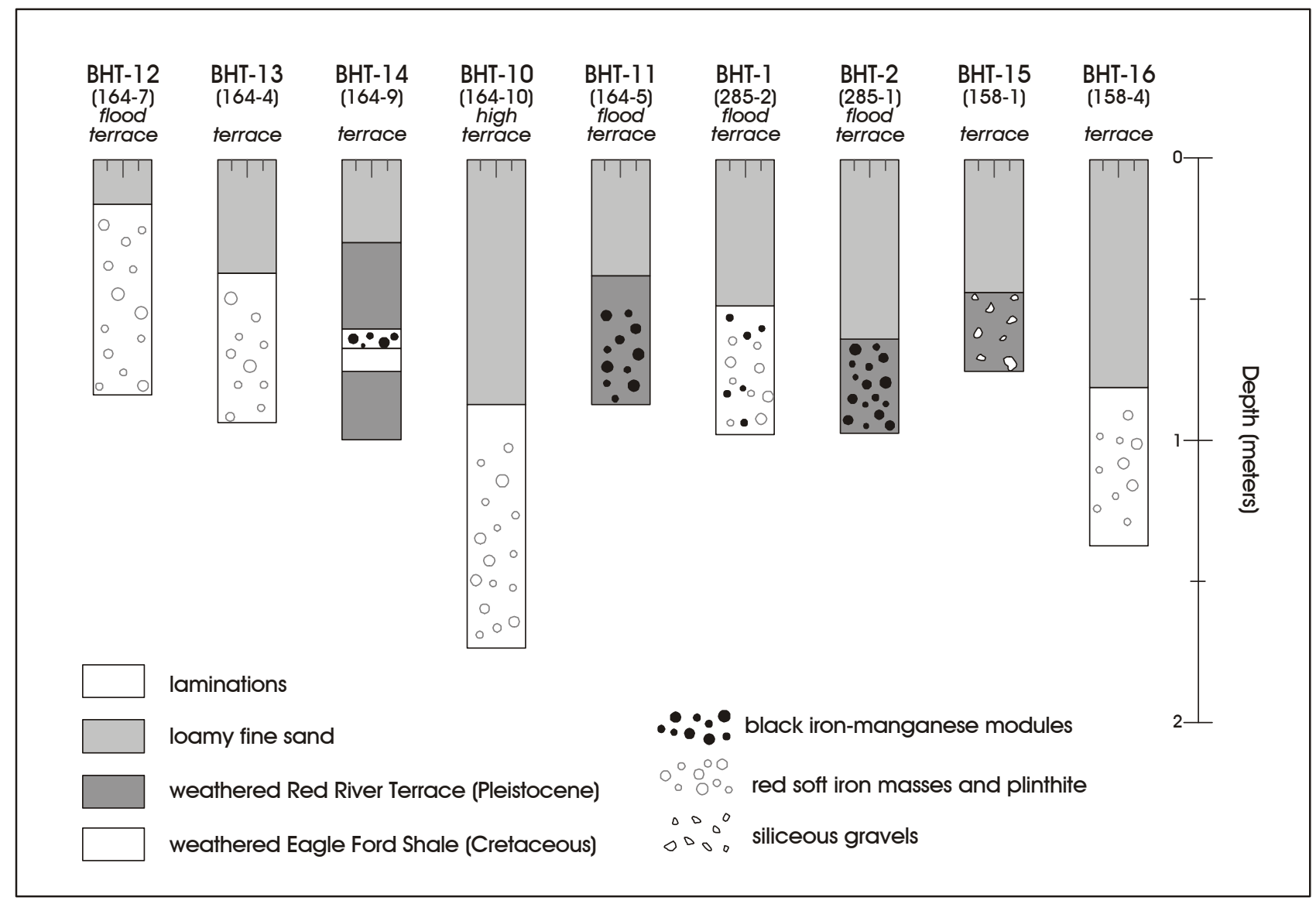

Figure 7. Diagrammatic cross sections of nine backhoe trenches from the southwest corner of the project area within sites 41LR158, 41LR164, and 41LR285. 


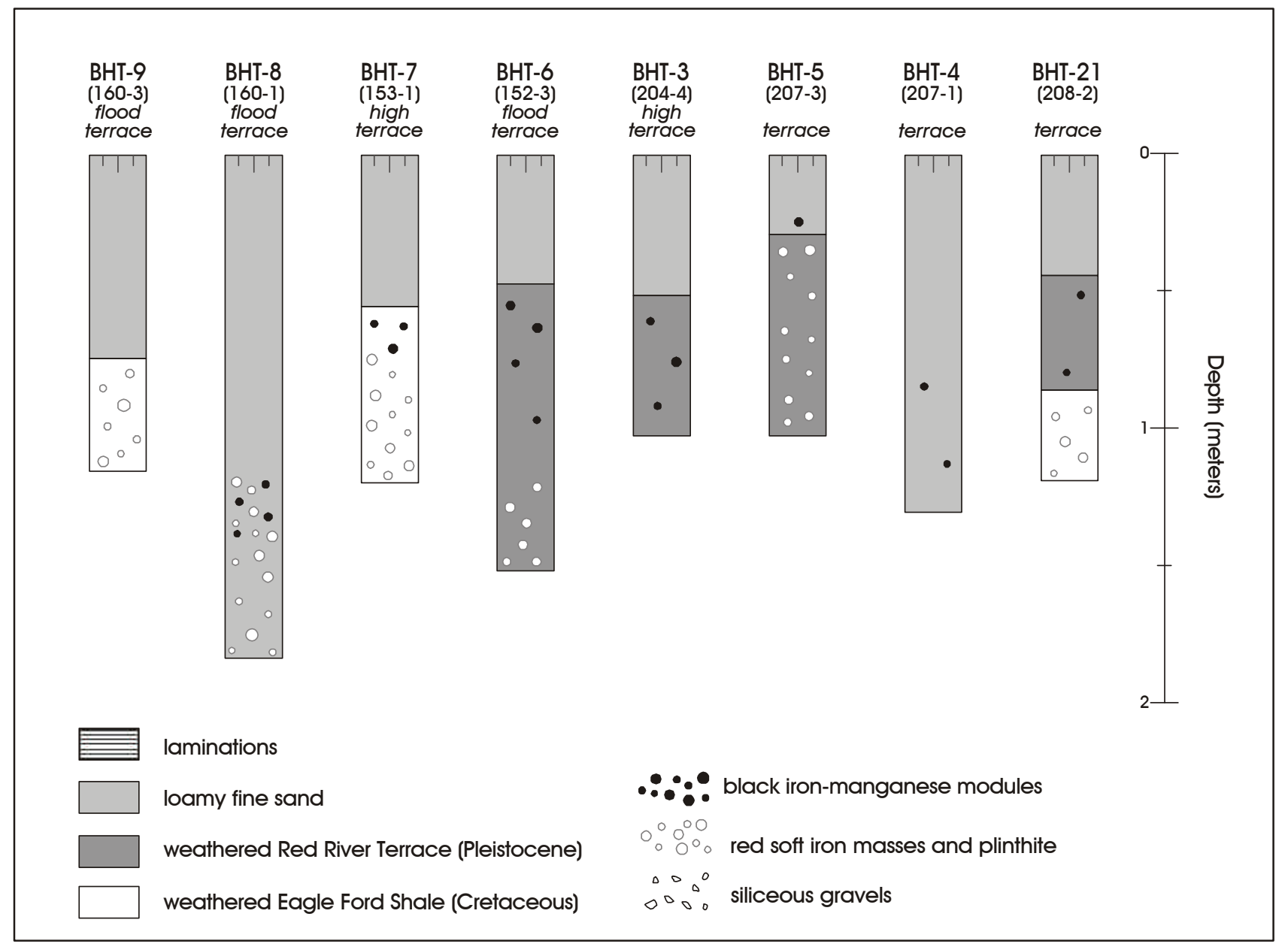

Figure 8. Diagrammatic cross sections of eight backhoe trenches excavated in the western portion of the project area within sites 41LR152, 41LR153, 41LR160, 41LR204, 41LR207, and 41LR208.

Within the younger and lower G3 geomorphic surface, the Pre-Holocene unit is expressed as a truncated gray clay (Bt, Btg, Btv) with reddish iron masses and plinthite or brown sandy loam, sandy clay loam, or clay with black iron-manganese nodules and red iron masses and clay films $(\mathrm{Bt}, \mathrm{Btc}, \mathrm{C})$. The Pre-Holocene unit in flood terrace positions (BHTs 1 and 12) is overlain by presumably Holocene sands that were most likely stream-transported (Figures 7-8).

\section{Holocene}

The Holocene unit was observed as a brownish loamy fine sand to fine sandy loam in flood terrace positions
(BHTs 1, 2, 6, 8, 9, 11, 12, and 20) (Figures 7-9). The Holocene unit truncates Cretaceous-aged Eagle Ford Shale or Bonham Formation in BHTs 1, 9, and 12 and truncates Pleistocene ancestral Red River terraces in BHTs 6, 11, and 12. In BHT 8 and BHT 20, the Holocene unit was observed to be greater than $1 \mathrm{~m}$ thick, but is most likely underlain by a Pre-Holocene unit at greater depth.

The Holocene unit in flood terrace positions within the G3 geomorphic surface was probably formed from stream-transported sands during high magnitude flood events. However, the Holocene unit may also be colluvial, in part, derived from gravity-driven sediments originating upslope. 


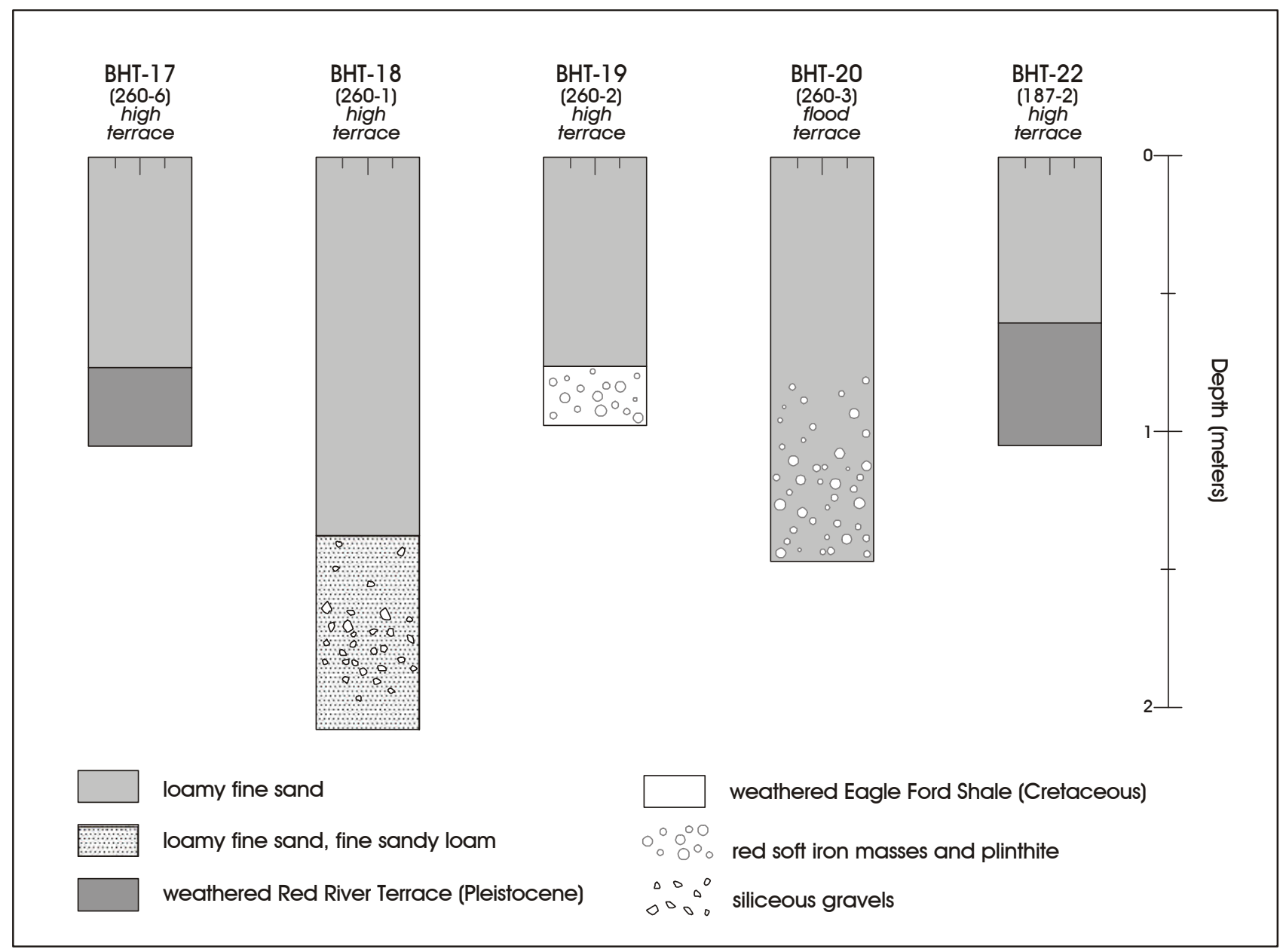

Figure 9. Diagrammatic cross sections of five backhoe trenches within the north-central portion of the project area within sites $41 L R 187$ and $41 L R 260$.

\section{Landscape Evolution}

The earliest evidence of landscape construction within the project area occurred in response to fluvial deposition and construction of the Qt4 terrace of the Red River (BHTs 2, 11, 14, 15, 17, 18, and 22) (see Figures 7-9). The majority of the G2 surface is associated with the Qt4 terrace, which based on stratigraphic position and degree of soil formation, appears to be Pleistocene in age. The soils typically consist of loamy fine sand A and E horizons over well-developed, clayey Bt horizons. Both layers appear to be pedogenically related, having formed coevally. During construction of the Qt4 floodplain, the Red River crosscut the higher G1 geomorphic surface to the south of the project area, creating gentle slopes that now grade into the Qt4 terrace.
Some time during the latter part of the Pleistocene, a major episode of channel entrenchment occurred in the project area creating the modern tributary valleys and the G3 geomorphic surface (BHTs 1, 2, 6, 8, 9, 11, 12, and 20) (see Figures 7-9). The first period of landscape stability occurred with the construction of flood terraces within the modern valleys, three to five feet above the modern channel thalwegs. Soils on the flood terraces have loamy fine sand and fine sandy loam $\mathrm{A}$ and $\mathrm{E}$ horizons over well-developed clay Bt horizons with reddish iron masses and plinthite or sandy loam to sandy clay loam Bt. Some soils on the flood terraces have Bt horizons with black iron-manganese nodules and red iron masses and clay films similar to the Qt4 terrace. However, because this flood terrace is probably intermittently flooded and because steep hillslopes grade into the terrace, it is possible that $\mathrm{A}$ and $\mathrm{E}$ horizons (sandy mantle) are Holocene 
alluvium or colluvium, and not pedogenically related to the underlying $\mathrm{Bt}$ horizons. The $\mathrm{Bt}$ horizons are still assumed to be truncated Pleistocene deposits. Previous work in the project area also suggests that steeper hillslopes and toeslopes grading into the flood terraces contain a sandy mantle that-in places-is probably Holocene (Crawford and Nordt 2001). The underlying $\mathrm{Bt}$ horizons are again assumed to be Pre-Holocene.

The last period of landscape development occurred with the formation of the modern floodplains following another period of channel downcutting. The floodplains typically occur less than three feet above the modern channel thalwegs. Previous work in the project area shows that the narrow floodplain deposits consist predominantly of loamy fine sands and fine sandy loams and the broader floodplain deposits consist of sandy clay loam and sandy clay deposits (Crawford and Nordt 2001). These depositional components of the floodplains are most likely Holocene in age and are underlain by scoured, presumably Pleistocene, Bt horizons.

\section{Geoarchaeological Research Issues}

One of the most controversial archaeological issues in east Texas is whether prehistoric sites can occur in a primary context buried within the so-called sandy mantle (Perttula et al. 1986; Thoms 1993a; Waters and Nordt 1996). The dominant characteristics of the sandy mantle outlined in Nordt and Bousman (1998) include:

\section{A-E soil horizons;}

2. An abrupt to clear, and irregular to smooth, textural boundary between the upper sandy mantle and the underlying Bt (clay-enriched) horizon;

3. Varying thickness and sometimes irregular ground surface of the sandy mantle;

4. Water worn siliceous gravels in the sandy mantle (A-E) but not in the underlying clay layer; and

5. Cultural materials in the sandy mantle but not in the underlying clay horizons.
Three models on the origin of the sandy mantle are currently accepted. The first, the pedogenic model, maintains the sandy mantle and underlying clay-enriched horizons were created by pedogenic processes (eluviation and illuviation) forming the characteristic A-E-Bt horizons (Waters and Nordt 1996). The A-E (eluvial) horizons were formed by the translocation of clay, sometimes in the form of lamella, down the profile. The clay lamella increase in size and frequency with depth, and eventually coalesce to form the $\mathrm{Bt}$ (illuvial) horizons. The pedogenic model argues the sandy mantle and underlying clay-enriched horizons formed as a result of pedogenesis and are therefore the same age. In this model all buried cultural materials are assumed to be in a secondary context, worked down through the profile from the surface by pedogenic processes (pedoturbation). Apparent stratigraphic cultural sequences within the sandy mantle may, in fact, be "reconstituted" due to pedoturbation of surface occupations over extended periods of time (Thoms 1993b).

The second model, the depositional model, maintains that the sandy mantle is a depositional unit unconformably overlying the older Bt horizons (Waters and Nordt 1996). Following this model, prehistoric occupation sites were buried within the sandy mantle by colluvial and eolian depositional processes during the Holocene. This model has been validated, in part, by the presence of in situ cultural features (Rodgers 1994) and buried A horizons in some areas. At some sites erosional features such as gullies and small-scale escarpments have also been buried by the sandy mantle (Thoms 1993a). The depositional model asserts buried sites can occur in a primary context within the sandy mantle.

Thoms (1993b) has suggested a third alternative, the graviturbation model. This model is a synthesis of the pedogenic and depositional models. The graviturbation model maintains that over time the sandy mantle slowly moves across the landscape due to gravity and turbation processes, while the underlying Bt horizons form as clays and are simultaneously translocated down the profile. Thoms (1993b:78) characterizes the graviturbation model as follows: the sandy mantle on landform crests (uplands) are typically thin; most welldeveloped Bt horizons are on hill crests; there are lithological and mineralogical similarities in the sand 
fraction between the $\mathrm{A}, \mathrm{E}$, and $\mathrm{Bt}$ horizons; clay lamella may form the Bt horizons; and there is evidence of "reconstituted" cultural stratigraphy.

Within the Camp Maxey project area, the pedogenic models seem to apply to the high terraces and intermediate terraces of the Red River (BHTs 3, 4, 5, 7, 10, 13-19, and 21-22) (see Figures 7-9). Due to the higher elevation, these landforms have been relatively unaffected by colluvial processes. Furthermore, no evidence of eolian processes were observed within these landforms. Thus, the intermediate terraces and high terraces are presumably pedogenically formed and Pre-Holocene in age.

The depositional model seems to apply to the sandy mantle that truncates Pre-Holocene units in flood terraces (BHTs 1, 2, 6, 8, 9, 11, 12, and 20) (see Figures 7-9) and floodplains. Depositional units within the flood terraces and floodplains are presumably stream-derived and Holocene in age.

\section{Geoarchaeology}

As previously stated, the position of the high terraces and intermediate terraces of the Red River suggest that the associated sediments are stable, pedogenically altered A-E-Bt profiles, and most likely Pre-Holocene in age (BHTs 3, 4, 5, 7, 10, 13-19, and 21-22) (see Figures 7-9). Consequently, a palimpsest of cultural materials spanning all of Texas prehistory may be present on these geomorphic surfaces. Cultural materials may have been pedoturbated into the sandy mantle (A-E) associated with these landforms. The prospect of finding deeply stratified materials below the sandy mantle-clay contact (E-Bt) is highly unlikely because the clay is resistant to pedoturbation, and presumably Pre-Holocene in age. The highest probability for finding buried cultural materials is most likely within the high terraces and intermediate terraces of the Red River within the deposits of the G2 geomorphic surface. The high density of cultural materials within the associated deposits recovered in previous excavations at Camp Maxey supports this notion (Lyle et al. 2001). However, any buried cultural materials within the Red River high terraces and intermediate terraces most likely occur in a secondary context as a result of pedoturbation from surface contexts.
Surface and buried cultural materials associated with flood terraces (BHTs 1, 2, 6, 8, 9, 11, 12, and 20) (see Figures 7-9) within the G3 geomorphic surface also most likely occur in a secondary context. Any buried cultural materials within the Holocene sandy mantle (A-E horizons) were probably stream or colluvially transported, or buried by these processes. There is also a high probability that cultural materials within the flood terraces have been pedoturbated. Again, the prospect of finding deeply stratified cultural materials below the sandy mantle contact is highly unlikely.

\section{Conclusions}

Future research within the project area incorporating pedological analytical techniques (mass-balance reconstruction, thin-section analysis), and geophysical techniques (ground penetrating radar) may lend further insight into the origins of landforms and deposits within the Camp Maxey project area, as well as create a proxy applicable to the sandy mantle throughout east Texas. The chronological information that is provided in this report should be considered tentative. 


\section{Chapter 6: Methodology}

\section{Introduction}

The field methodology employed is based, in part, upon the results from the previous survey efforts (Lyle et al. 2001; Nickels et al. 1998). These survey efforts generally defined areas of artifact densities within each recorded site that would condition subsequent placement of backhoe trenches and associated excavation units. Backhoe trenching, shovel testing, and/or excavation of testing units were conducted at each of the 23 sites. Although, at various sites additional shovel tests were excavated under the current efforts, their primary function was to further delimit ephemeral site bounds, not necessarily to determine factors of site eligibility.

The project archaeologist, the crew chief, and a crew of five field technicians carried out the field investigations over the course of seven 10-day sessions. During the duration of the project, efforts were made to maintain the field technicians in close proximity for safety reasons. However, due to the varied level of investigations required on individual sites, two or more sites were frequently under excavation simultaneously. The crew chief was assigned supervisory duties over a single site at a time, while the project archaeologist supervised the remainder of the ongoing sites. In all cases, however, the project archaeologist was responsible for the direction of all fieldwork performed. Communication was facilitated among the separated field crews via hand-held radios.

Upon completion of investigations at each site, a detailed, hand-drawn site map was produced. These maps were recorded on archival quality graph paper and bearings were generated using hand-held compasses and $50 \mathrm{~m}$ and $100 \mathrm{~m}$ reel tapes. Subsequent to the field investigations, each map was digitized by the drafting department at CAR, and reproductions are included in this report.

\section{Mechanical Excavations}

Eight-four backhoe trenches (BHTs) were excavated among 18 of the 23 sites investigated. This method of testing has become relatively commonplace in archaeological investigations and serves not only to prospect for cultural deposits and features, but also to provide a comparative view of the stratigraphy to be encountered during subsequent manual excavations. The machine employed for the current investigations was a Case 580 Super K tractor equipped with a Construction King Extend-A-Hoe arm attachment and 24" bucket. Typically, a clean-out plate is welded to the teeth of the bucket for archaeological trenching to produce a cleaner view of trench floors, however, due to the abundant root systems encountered, occasional gravel deposits and ferruginous sandstone formations, this method proved counterproductive to trenching efforts, and a standard, toothed bucket was utilized.

The strategy employed for placement and excavation of backhoe trenches was to explore, based upon the survey phase shovel test data, the apparently densest portion of each site. Specifically, the trenches were excavated adjacent the most productive shovel tests to further investigate temporally diagnostic cultural material and/or investigate possible features. Shovel tests were considered "productive" based upon the presence of diagnostic artifacts or density of artifacts, suggestive of nearby features or cultural middens.

Some limitations, however were encountered during placement of backhoe trenches. Access proved to be the greatest impediment. Sites located within the western-central and northwestern portion of the project area were the last to be tested and, as such, were subjected to a greater amount of rain experienced throughout the latter part of the field investigations. In-filling, via wall slumpage, was common and often required re-excavation of the trench with the backhoe or abandonment of the trench. 
The excavation of each trench was closely monitored for impact to potential intact features or significant deposits. The excavated material was observed and all cultural material was collected and maintained with the backhoe trench provenience. Each backhoe trench profile was described on a unique form.

\section{Manual Excavations}

\section{Shovel Tests}

A total of 757 shovel tests (STs) have been excavated at the 23 sites discussed in this report. Of these, two hundred and sixty-three were excavated during the testing phase to further delimit site bounds as established during the previous survey phase(s). While not all sites warranted further shovel tests, some of the larger sites containing isolated or sparsely located positive tests required more accurate boundary definition to aid the placement of backhoe trenches and excavation units. All shovel tests were excavated into the undisturbed basal clayey stratum, where possible. Where shovel tests could not be excavated into the basal clayey stratum, the shovel tests exhibited a depth that precluded manual exploratory efforts. These shovel tests generally exhibited depths in excess of one meter. The shovel tests were approximately 30$\mathrm{cm}^{2}$ and were excavated in 10-cm levels. Each shovel test was screened through $1 / 4$ " mesh hardware cloth and recorded on a unique shovel test form.

\section{Excavation/Test Units}

During the current testing efforts, 77 excavation/test units (XUs and TUs) were excavated. Excavation units per site varied from one to seven based upon site size, distribution of cultural material, and density of cultural material. An average of approximately three units per site was deemed adequate to assess NRHP site eligibility and determine whether further mitigative efforts would be warranted.

When feasible, excavation units were placed immediately adjacent backhoe trenches, with a unit wall sharing an associated backhoe trench wall. This method allowed for a more efficient means of exca- vation by permitting the excavator to view the various strata to be encountered during manual excavation. In addition, the physical demands of manual excavation are lessened as the excavator may dig while standing inside the relatively shallow $(\sim 1 \mathrm{~m})$ trench. This positioning permits greater leverage using hand tools, as opposed to excavation of a stand-alone unit not adjoining a backhoe trench.

All horizontal provenience were maintained in $1 \mathrm{~m}^{2}$ levels, with large (ca. $>5 \mathrm{~cm}$ ) in situ burned rock, large (ca. $>3 \mathrm{~cm}$ ) artifacts, and temporally diagnostic artifacts point provenienced whenever possible. Vertical excavation levels did not exceed $10 \mathrm{~cm}$ in thickness. Due to the discrete textural and color changes in the stratigraphy of the upper stratum (i.e., sandy mantle), arbitrary $10 \mathrm{~cm}$ levels were excavated. These arbitrary levels were maintained until the basal clayey substrate was encountered; at which time a final $10 \mathrm{~cm}$ level was excavated into the clay to ensure that cultural material possibly translocated into the upper aspect of the basal material was not overlooked. All excavated sediments and soils were dry-screened through $1 / 4$ " mesh hardware cloth. The results of excavation of each level were recorded on a unique form, including provenience data, soil data, artifactual material recovered, inclusions, disturbances, and a sketch of features (if any) encountered. Upon completion of each excavation unit, wall profiles were photographed and accurately depicted on archival quality graph paper.

All cultural material encountered during excavation was collected and recorded on field forms relative to their encountered provenience. Various samples were collected in the field to provide relevant data. These include the collection of all snail shell, faunal, and other ecofactual material observed. Soil samples were collected from throughout the vertical column at select sites and from each feature encountered. These samples, where warranted, will be used for soil susceptibility, macrobotanical (flotation), and microbotanical (e.g., pollen, and phytoliths) analyses.

\section{Laboratory}

Upon completion of each ten-day session, all recovered artifacts and special samples along with the associated paperwork were submitted to the 
laboratory at CAR for processing and temporary curation. Processing consisted of artifact washing, a general category sort, cataloging, and entry into a standardized database. Subsequent to this initial laboratory processing, the various artifact categories were submitted to specialists for analyses. Following the formal analyses, the results were then incorporated into the database for final curation.

After completion of the reporting for the current project, and in preparation for future work, the artifacts and records from the sites tested during this project and the previous survey were pulled. The survey artifacts and records will be curated at the Texas Archeological Research Laboratory (TARL) with the associated records and recovered artifacts from the testing effort. Any recataloging or reanalysis of material that results in different data than that presented herein will be documented both on the artifact tags and in the accompanying records.

Final curatorial processing was conducted in accordance with 36 CFR 79 (Curation of Federally Owned and Administered Archaeological Collections), and other proprietary standards espoused by TARL, the permanent curatorial facility for the Camp Maxey project.

\section{Special Analyses}

\section{Native Ceramics}

Analysis of the Camp Maxey III ceramics is consistent with the methods described in Nickels et al. (1998) and Lyle et al. (2001). Sherd and vessel analysis is based on differences in paste and temper, type of sherd (i.e., rim, body, or base), rim and lip form (cf. Brown 1996:Figure 2-12), decoration (if present), decorative element (if identifiable), surface treatment (smoothing, burnishing, or polishing; [see Rice 1987]), and oxidation patterns (cf. Teltser 1993). Sherd cross sections have been inspected macroscopically and with a $10 \mathrm{x}$ hand lens to determine the character of the paste and its inclusions. Determining the firing atmosphere - the conditions of temperature, duration of firing, clays with different organic contents, or the amount of oxygen available at the time of firing - is based on the identification of the firing core in the sherd cross sections and the identification of oxidation patterns as defined in Teltser (1993:535-536, Figure 2). In all cases, however, each sherd was simply too small to ascribe a type or variety. As such, the sherds were tabulated by temper and surface treatment or decorative element (see Chapter 7: Results). The ceramic analysis was conducted by Dr. Timothy K. Perttula.

\section{Lithics}

In order to provide continuity in the analysis phase during the process of NRHP eligibility determination, all lithics recovered during the previous CAR surveys from the sites that form the focus of this subsequent testing (Lyle et al. 2001; Nickels et al. 1998), underwent re-analysis. Lithic analysis was divided into two categories, tools and debitage. Tools are classified as intentionally modified and/or utilized lithics that range from formal, typed dart and arrow points to expedient, edge modified flakes used to scrape or cut. Debitage is classified as the by-product of tool preparation, tool manufacture, or tool rejuvenation. Metric traits, as well as macroscopic and low-power microscopic morphological characteristics were recorded for each of the 2,182 debitage, and the 160 tools recovered during the three CAR investigations. Project archaeologist Richard Mahoney conducted the analysis of the tools while Sylvia Rena conducted the debitage analysis. Both analyses were conducted under the supervision of Dr. Steve A. Tomka.

\section{Radiometric Dating}

An attempt was made to recover all charcoal or carbon-rich samples encountered during the project. However, few samples were judged to possess depositional integrity, therefore only eight samples were submitted for radiometric dating. All samples were point provenienced, where possible. Specifically, the position of each sample both vertically and horizontally - relative to the specific unit datum - was calculated and recorded on a unique, special sample log. Each sample recovered was placed in an aluminum foil packet, and stored in the controlled laboratory setting at CAR until submittal to Beta Analytic, Inc., of Miami, Florida. 


\section{Soil Susceptibility}

Numerous soil samples were recovered from various sites during the current investigations to test for magnetic sediment susceptibility. The process of measuring the change in magnetic susceptibility of the sediments involves collecting small soil samples at regular intervals throughout the vertical column of an excavation unit, backhoe trench, or shovel test. The potential change in value of the samples can indicate an increase or decrease in the amount of organic material through the various horizontal levels. Ideally, these peaks in magnetic susceptibility will correspond to an increase in artifact densities.

Samples recovered from the selected units were placed in plastic bags and stored in the controlled laboratory at CAR until analysis was performed. Prior to analysis, all sediment samples were air dried on a nonmetallic surface. After drying, the samples were then ground to a uniform grain size using a ceramic mortar and pestle. This was done to standardize particle size and make the material easier to handle and pack into sample containers. The ground samples were placed into a MS2B Dual Frequency Sensor that, in conjunction with a MS2 Magnetic Susceptibility Meter, provided the magnetic susceptibility of each sample. The results of these analyses are presented in Appendix B. 


\section{Chapter 7: Results}

\section{Richard B. Mahoney, Timothy K. Perttula, and Sylvia Reyna}

\section{Introduction}

This chapter provides a detailed discussion of each site investigated during the current testing phase (Figure 10 [Figure included in separate supplement]). Results of applicable special analyses will be presented on a site-by-site basis, including an interpretation of the temporal chronology exhibited and intra- and/or inter-site comparisons, when applicable. Cultural material recovered from each site will be discussed by the analysts and incorporated into the descriptive text to provide a better understanding of the assemblages. For each site, Dr. Timothy Perttula provides the discussion of the native ceramics. Richard Mahoney and Sylvia Reyna provide discussions of the tools and debitage, respectively. The ceramic discussions are broken down by excavation phase, while the debitage and tool analysis simply provide a single synthesis of all material recovered from the site. Finally, note that the senior author is responsible for the remainder of the descriptive and interpretive results herein. Discussions of the sites will be grouped into two sections, those recorded during the 1998 survey (Nickels et al. 1998), and those recorded during the 1999-2000 survey (Lyle et al. 2001).

Some evidence of disturbance, either natural or historic, was encountered at each site under this phase of work. Natural factors include bioturbation (root, rodent, or insect disturbance), erosion, and the pedogenic processes specific to the sandy mantle in northeast Texas (see Chapter 5). Historic factors include roads, homesteads, farmland, and military activities. Even when encountered individually, all of these aspects have the potential to affect the temporal integrity of an archaeological site to such a degree that National Register of Historic Places (NRHP) eligibility for specific questions could be compromised.

\section{Natural Factors of Site Disturbance}

Cutbanks and erosional features within the project area have left the root systems of various vegetation exposed. Most of the root systems observed, including those of moderate-sized elm and oak, reveal expansive horizontally oriented root systems; very few taproots were noted. As many of the sites in the project area are located within—or adjacent to-rich riparian zones, it is conceivable that successive generations of vegetation have completely obliterated cultural deposits or features.

Rodent and insect activity within the sandy loams of the project area is abundant. Without exception, all 77 excavation or test units (XUs and/or TUs) excavated encountered at least one, and usually two or more, active or in-filled rodent burrows or insect krotovinae. The density of these forms of natural disturbance, however, was not such that it would have completely destroyed significant deposits or features. Smaller artifacts and ecofacts, such as lithic flakes, bone, charcoal, and vegetal material were frequently encountered in burrows.

Erosion is a common occurrence throughout the project area. Regardless the origin of the upland sands, drainage of these uplands has probably substantially altered these landforms since their original deposition or formation. Evidenced on several sites, upland drainages have either subsequently dissected archaeological sites or were present during prehistoric occupation and have since in-filled. It is likely that these forces have provided for the fluvial and/or gravitational transport of artifacts untold distances away from their point of origin. Indeed, lithic flakes and small fragments of burned rock can be found in the numerous intermittent streambeds throughout the facility, the product of erosional force. 
An explanation of the "sandy mantle" issue is best left to the geomorphologist (see Chapter 5), but a few archaeological observations are certainly relevant to this issue. Note that roughly 40 percent of the material recovered from the current project occurred below $40 \mathrm{~cm}$ in depth. In addition, the presence of intact features (see below), some to depths of $75 \mathrm{~cm}$ bs, suggests that in several cases these cultural deposits are in situ within the homogenous unit of fine sandy loam. Based upon the context in which deposits and features occur within the project area, it is the opinion of the senior author that the "sandy mantle" is probably pre-Holocene in age. As such, it formed the primary surface for native occupation. These deposits have subsequently been reworked by a combination of alluvial and colluvial processes which significantly altered the terrain through erosion and subsequent redeposition of the deposits within upland settings.

\section{Historic Factors of Site Disturbance}

Figure 11 (Figure included in separate supplement) depicts recorded historic roads that dissect the project area. These roads, connecting some of the original European inhabitants' farmsteads, probably loosely followed native trails across the terrain. Later historic roads were dictated by property boundaries, with the further subdivision of parcels of land and post-Reconstruction sharecropping. Twentieth-century militaryera roads followed divisions of assigned activity and bivouac areas. With the exception of the extant paved roads, the effect of road usage is still visible across the landscape, with road cuts through the soft sandy loams as deep as one meter below original ground surface. The evidence of site disturbance is documented in various site discussions that follow. Of note, the only Paleoindian dart point recovered during the testing phase was encountered adjacent a road cut, east of 41LR158.
The original European settlers would have constructed houses in preferred locations that were atop upland landforms, on well-drained soils with ready access to potable water. Later, sharecroppers renting parcels of farms, would have mirrored this settlement pattern, although they would have had to consider the proximity to existing roads as a factor in house location. Similarly, earlier native cultures shared these preferred locations for open campsites, and later for horticultural or agricultural use. The establishment of an historic homestead atop a prehistoric site probably had varying impact on the underlying deposits. Unfortunately, once the project area was acquired by the United States Army all historic standing structures were demolished and then buried where they once stood. This process usually involves the excavation of a deep trench alongside a structure and subsequent in-fill with the bulldozed debris. It is unlikely that significant, prehistoric intact deposits surrounding historic homesteads would have survived these extensive subsurface activities.

The very nature of the facility was, and still is, to serve as a training camp for soldiers. These training activities have included the use of heavy machinery such as tanks and troop transporters, excavation of trenches, foxholes, and tank pits, and deployment of munitions, from small arms to anti-tank and anti-aircraft missiles. Figure 12 (Figure included in separate supplement) depicts the intense activity areas that were in use during the WW II training exercises at the camp. As illustrated, virtually every site in the northern half of the facility was susceptible to impact from weapon fire. The southwestern quadrant of the facility was used primarily for training maneuvers for ground forces. Spent casings and bullets were encountered on a majority of the tested sites, and a large spent bullet, possibly anti-tank, was located at 41LR207, well outside of the specified impact area. The entire facility, then, was susceptible to disturbance via military activity. 


\section{LR152}

\section{Description}

Site 41LR152 is located in the southwestern portion of the facility along the right descending bankline of an unnamed tributary of Visor Creek (see Figure 10 in supplement). The site is situated atop an upland landform of Lassiter series silt loams at $480-490 \mathrm{ft}$ AMSL. The vegetation community consists of the Quercus nigra-Ulmus americana Woodland class, providing roughly ten percent ground surface visibility.

A total of four backhoe trenches (BHTs), five excavation units (XUs/TUs), and 25 shovel tests (STs) have been excavated to define this site boundary (Figure 13). Based on these data, the site measures

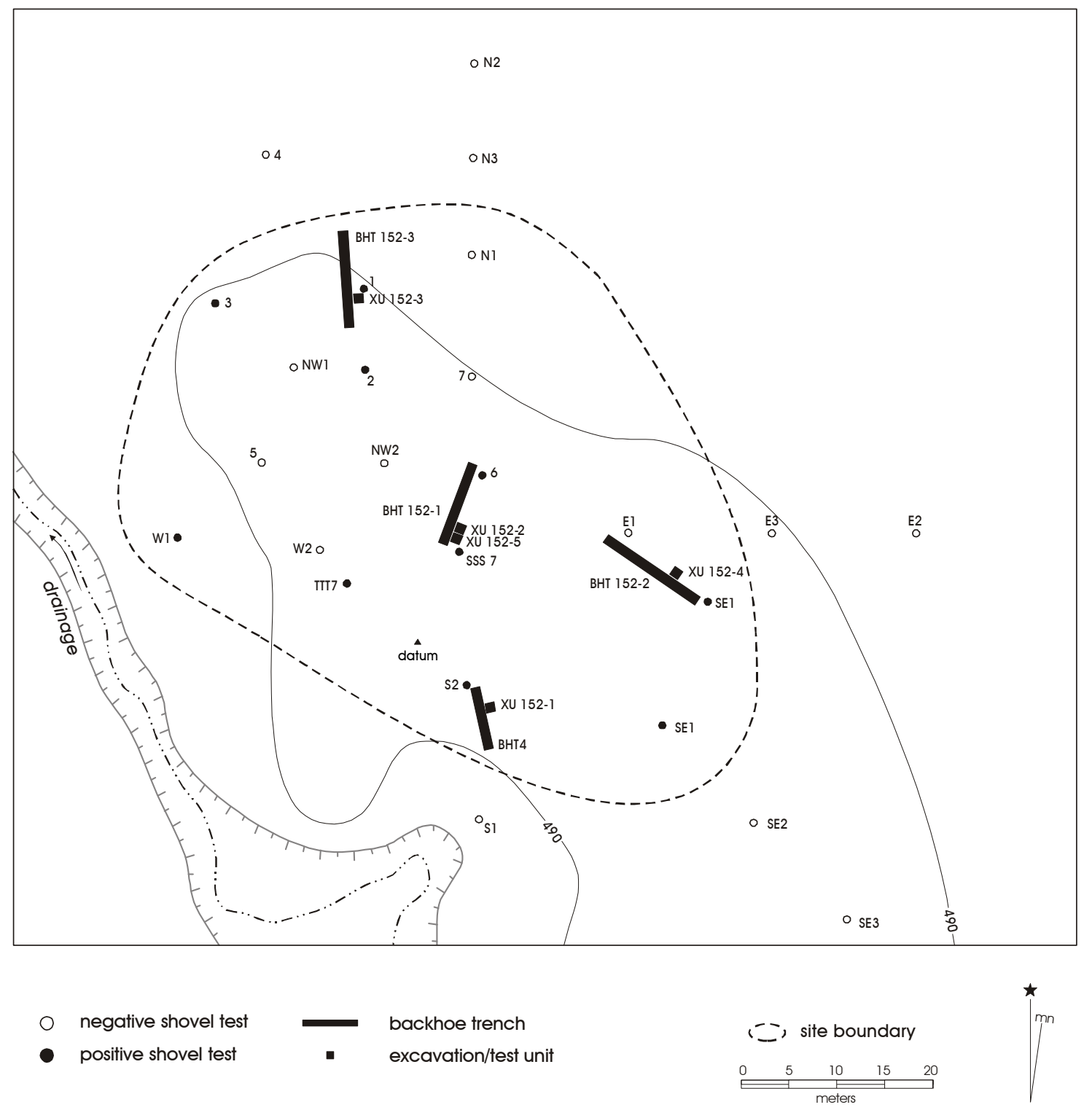

Figure 13. Site map - 41LR152. 
approximately $60 \times 55-\mathrm{m}$, and covers an area of $2,900 \mathrm{~m}^{2}$. Seventeen shovel tests were excavated within the present site boundary, ten (59\%) of which were positive. Cultural material extends from 0-80 $\mathrm{cm}$ bs, with the greatest density (40\%) of provenienced artifacts encountered within levels three and four, or 20-40 cm bs.

\section{Discussion}

Within three of the excavation/test units, a weakly formed paleosol was discernible approximately 15$35 \mathrm{~cm}$ bs. A total of 30 native ceramic sherds, one ceramic vessel, 20 debitage and one edge-modified flake were recovered, with mean depths of recovery $36 \mathrm{~cm}$ bs and $27 \mathrm{~cm} \mathrm{bs}$, respectively. Additionally, a single biface fragment (untypeable) was recovered within Level-3 (20-30 cm bs) of an excavation/test unit. The recovery of these materials is consistent with the paleosol, or living surface, identified by the geomorphologists.

However, the recovery of an intact native ceramic vessel, with a terminal depth of $70 \mathrm{~cm}$ bs, is a definite anomaly (Figure 14). Consultation with Dr. Perttula suggests the possibility of an associated burial. Excavations did not, however, reveal subsurface disturbance suggestive of a pit feature such as a burial. The intact vessel was recovered oriented in an upright position with no associated artifacts. The sediments contained within the jar were removed in a controlled laboratory setting and should undergo residual analyses.

A single feature was recorded in arbitrary Level-4 of XU 1 adjacent to BHT 4. The feature is a vertically oriented wooden post apparently burned in situ (Figure 15). The post is approximately $20 \mathrm{~cm}$ in diameter and appears natural, not hewn, with the basal end chopped, not sawn. Only a $25 \mathrm{~cm}$ vertical portion of the post remains, with the uppermost aspect terminating at $34 \mathrm{~cm}$ bs within the identified paleosol. No evidence of continuation of the post above this level was noted during excavation. However, the associated posthole or mold was discernible, and the surrounding matrix consisted of burned clay and charcoal flecking.

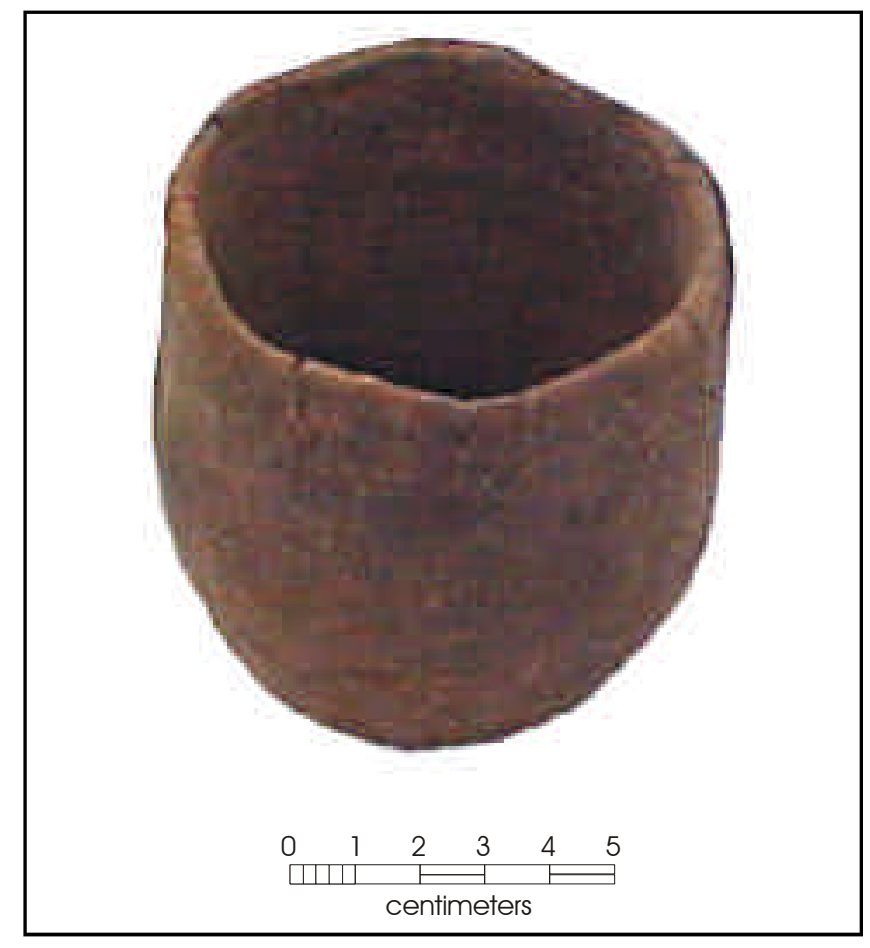

Figure 14. Intact native ceramic vessel recovered from Level 7 of XU-2, 41LR152.

\section{Radiocarbon}

Two carbon samples recovered in close proximity to the ceramic vessel were collected and submitted to Beta Analytic, Inc., for radiometric dating (Table 1). The first sample, assigned a CAR catalog number, was assigned a Beta Analytic number (Beta No. 153589; Cat. No. 129-1). It returned a calibrated radiocarbon age at 2 sigma of 2741-2358 вр (ВC 792-409). If accepted, this range would place the ceramic vessel at the very onset of the Woodland period in northeast Texas. Conversely, the second sample (Beta No. 153590; Cat. No. 129-2) returned a calibrated radiocarbon age at 2 sigma of 428-4 вр (A.D. 1522-1946). If accepted, this second range would place the vessel anywhere from immediately prior to the De SotoMoscoso entrada into Caddoan territory, to immediately after the United States military abandoned Camp Maxey. 


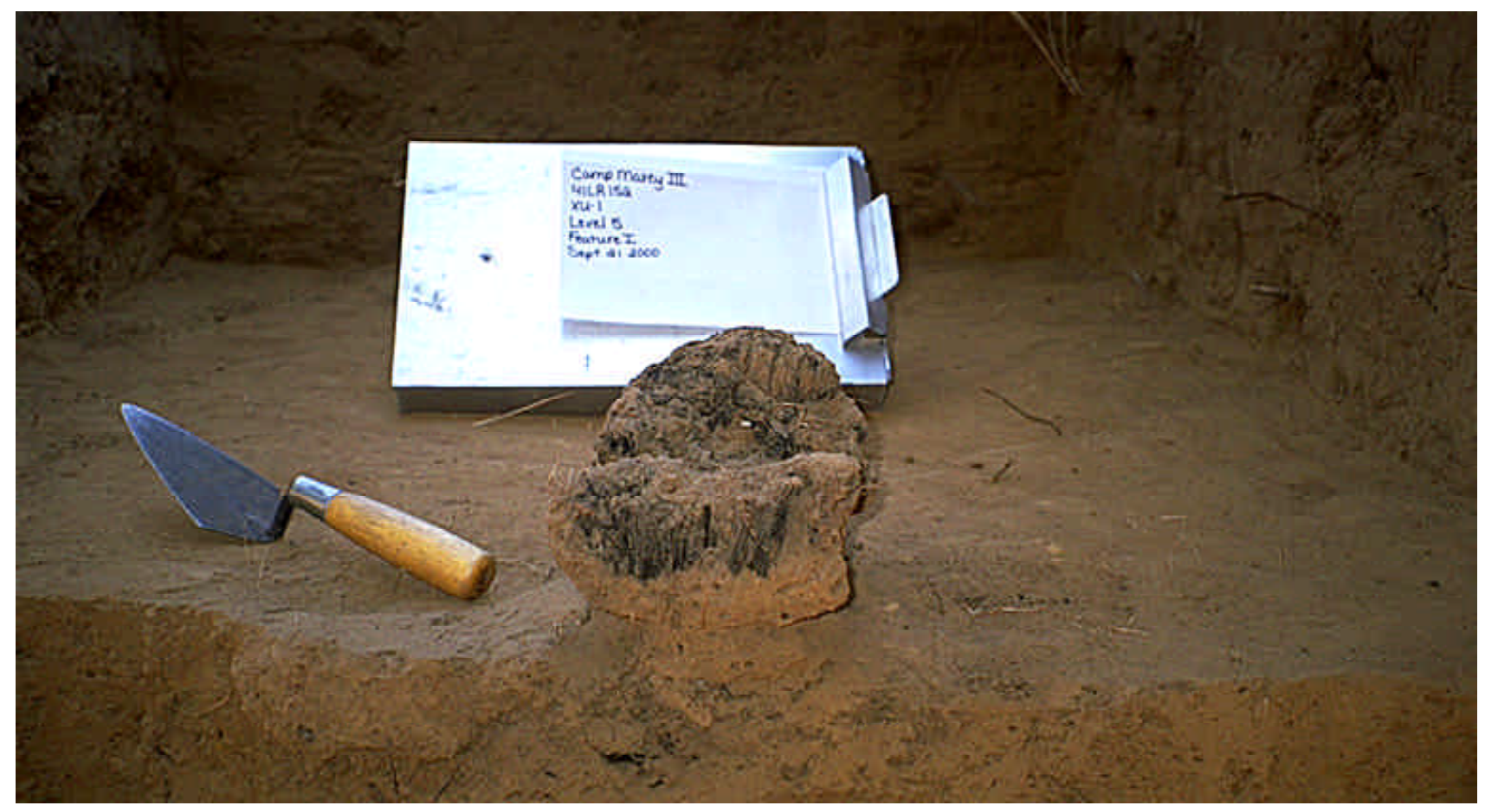

Figure 15. Remnant of structural post photographed in Level 5 of XU-1, 41LR152.

A third sample collected directly from the wooden post in XU 1 was submitted for radiometric dating. The sample (Beta No. 153588; Cat. No. 116-2A) returned a calibrated radiocarbon age at 2 sigma of 1304-1073 вр (A.D. 646-877). This date would place the wooden post at the beginning of the Formative Caddoan period, a time when horticulture began and a trend towards sedentism was in place (Perttula et al. 1993).

The paleosol identified at 41LR152 probably formed over an interval of several thousand years before subsequent burial by alluvial deposition (Nordt and Bousman 1998:14). The wooden post, which has an accepted radiometric date of 1304-1073 вр, is intrusive into this paleosol, as evidenced by the associated posthole or mold. If the activity that buried the intact vessel were younger than the post (after 1304 вр), then the intrusive activity should be discernible within the strata similar to that of the post. However, if the activity were significantly older than the post (prior to $2358 \mathrm{BP}$ ), then it is feasible to assume that the intrusive activity may no longer be discernible in the stratigraphy. Therefore, the later date of 428-4 вр (A.D. 1522-1946) is rejected as being too young. Thus, the earlier date of 2741-2358 вр (BC 792-409) is accepted, suggesting the vessel is affiliated with the Woodland period.

Table 1. Radiometric results from Camp Maxey III samples

\begin{tabular}{|c|c|c|c|c|c|c|c|c|}
\hline Beta \# & Catalog \# & SITE & C14 & BR & $\begin{array}{c}\text { 13C/12C } \\
\text { Ratio }\end{array}$ & $\begin{array}{c}\text { Conventional } \\
\text { Radiocarbon } \\
\text { Age }\end{array}$ & $\begin{array}{c}\text { Calibrated Radiocarbon Age } \\
\text { at 1 Sigma }\end{array}$ & $\begin{array}{c}\text { Calibrated Radiocarbon Age } \\
\text { at 2 Sigma }\end{array}$ \\
\hline 153588 & $116-2 \mathrm{~A}$ & $41 \mathrm{LR} 152$ & $\mathrm{X}$ & & -28.7 & $1240+/-60 \mathrm{BP}$ & $\mathrm{AD} 666-773(1284-1177 \mathrm{BP})$ & $\mathrm{AD} 646-877(1304-1073 \mathrm{BP})$ \\
\hline 153589 & $129-1$ & $41 \mathrm{LR} 152$ & $\mathrm{X}$ & & -24.8 & $2490+/-40 \mathrm{BP}$ & $\mathrm{BC} 765-519(2714-2468 \mathrm{BP})$ & $\mathrm{BC} 792-409(2741-2358 \mathrm{BP})$ \\
\hline 153590 & $129-2$ & $41 \mathrm{LR} 152$ & $\mathrm{X}$ & & -26.7 & $220+/-40 \mathrm{BP}$ & $\mathrm{AD} 1640-1790(310-160 \mathrm{BP})$ & $\mathrm{AD} 1522-1946(428-4 \mathrm{BP})$ \\
\hline 153591 & $89-1-1$ & $41 \mathrm{LR} 164$ & & $\mathrm{X}$ & -21.0 & $2040+/-40 \mathrm{BP}$ & $\mathrm{BC} 36-$ AD $76(1985-1874 \mathrm{BP})$ & $\mathrm{BC} 47-\mathrm{AD} 126(1996-1824 \mathrm{BP})$ \\
\hline 153592 & $89-1-2$ & $41 \mathrm{LR} 164$ & & $\mathrm{X}$ & -20.6 & $2320+/-40 \mathrm{BP}$ & $\mathrm{BC} 388-209(2337-2158 \mathrm{BP})$ & $\mathrm{BC} 397-200(2346-2149 \mathrm{BP})$ \\
\hline 153593 & $89-1-3$ & $41 \mathrm{LR} 164$ & & $\mathrm{X}$ & -21.2 & $2180+/-40 \mathrm{BP}$ & $\mathrm{BC} 199-60(2148-2009 \mathrm{BP})$ & $\mathrm{BC} 350-4(2299-1953 \mathrm{BP})$ \\
\hline 153594 & $332-1$ & $41 \mathrm{LR} 187$ & $\mathrm{X}$ & & -25.4 & $170+/-40 \mathrm{BP}$ & $\mathrm{AD} 1662-1948(288-2 \mathrm{BP})$ & $\mathrm{AD} 1648-1950(302-0 \mathrm{BP})$ \\
\hline 153595 & $333-1$ & $41 \mathrm{LR} 187$ & $\mathrm{X}$ & & -25.6 & $3650+/-40 \mathrm{BP}$ & $\mathrm{BC} 2131-1959(4080-3908 \mathrm{BP})$ & $\mathrm{BC} 2141-1917(4090-3866 \mathrm{BP})$ \\
\hline
\end{tabular}




\section{Cultural Material}

\section{Native Ceramics}

\section{Investigations}

The eight sherds from the site include six that are plain, one with an exterior red slip (made from a hematiterich clay), and one with a rectilinear-curvilinear engraved decoration (probably from a carinated bowl). The sherds are from well-made coiled vessels, with thin walls (5.4 $\pm 0.5 \mathrm{~mm}$ thick), and are grog-tempered. Twenty-five percent also have finely crushed bone (including the red-slipped sherd from ST E-1) and another 25 percent have grit or crushed pebbles added as temper. Core cross-sections indicate that the sherds are from vessels that were fired in a reducing environment, but cooled in a high-oxygen environment (that is, they have a dark core with a very thin oxidized layer on the exterior; see Teltser 1993:536, Figure $2 \mathrm{~F}-\mathrm{G}$ ).

The plain grog-tempered red slipped body sherd is probably from a Sanders Plain vessel, which according to Brown (1996:401) is a "grog tempered slipped and undecorated ceramic." Without a plain slipped rim sherd, however, the typological identification must be considered tentative. Red-slipped ceramics, particularly plain red-slipped wares, are abundant along the middle reaches of the Red River valley during the Middle Caddoan period, ca. A.D. 1100-1300 (see Krieger 1946; Bruseth 1998). The rectilinearcurvilinear engraved sherd is also consistent with a Middle Caddoan age for the 41LR152 ceramics.

\section{Investigations}

The ceramic sample from 41LR152 includes 22 sherds, six of which were less than $1 \mathrm{~cm}$ in length, and one whole vessel. These are from Units 1, 2, 4, and 5 , between $20-70 \mathrm{~cm}$ bs.

Only one sherd is decorated, and this is a red-slipped grog-tempered bottle body sherd from Unit 1 . One redslipped sherd is not much to hang one's prehistoric cultural and/or temporal hat on, but in conjunction with the red-slipped and engraved sherds recovered during the archaeological survey (Nickels et al. 1998:49), it seems probable that site 41LR152 was probably occupied during the Middle Caddoan period.

A grog-bone-tempered plain rim sherd (direct, with a rounded lip) is from Unit 1, 60-70 cm bs. The other sherds are plain body sherds tempered with grog, grog-hematite, grog-hematite-bone, bone-grit (crushed rock), and bone-hematite-grit. None have any form of surface treatment. About 63 percent of all the sherds have only grog temper, followed by grog-hematite (12.5 percent), grog-bone (6 percent), grog-hematitebone (6 percent), bone-grit ( 6 percent), and bonehematite-grit (6 percent). The one plain grog-bonetempered sherd has thick body walls $(8.2 \mathrm{~mm})$, compared to all the other temper groups, as thickness for the other temper groups ranges from 5.4-6.5 $\mathrm{mm}$. The mean wall thickness for the grog-tempered sherds is $6.25 \pm 1.38 \mathrm{~mm}$.

More than 64 percent of the sherds are from vessels fired in a reducing environment. This is comparable to the few other reasonably large Early to Middle Caddoan ceramic samples from Camp Maxey (Lyle et al. 2001; Nickels et al. 1998).

The whole vessel is from Unit $2,60-70 \mathrm{~cm}$ bs. It is a fine grog-tempered plain jar, of undetermined type, with a direct rim and a flat lip, and a flat base. The jar is small in size, standing only $9.2 \mathrm{~cm}$ in height, with an $8.8 \mathrm{~cm}$ orifice diameter, and a $5.4 \mathrm{~cm}$ basal diameter; rim and upper body walls are $5.9 \mathrm{~mm}$ in thickness. It has an estimated volume of $340 \mathrm{ml}$. It appears to have been fired in a reducing environment, and both interior and exterior surfaces are brown to very dark grayish-brown (10YR 3/2 to $10 \mathrm{YR} 4 / 3$ ) in color. The jar has been smoothed on both interior and exterior surfaces, especially near the rim, but the exterior vessel surface is still rather lumpy, as if the smoothing surface treatment had not been consistently applied across it. 


\section{Lithics}

\section{Tools}

Two lithics classified as tools were recovered from 41LR152. A single edge-modified flake exhibiting use wear and heat treatment was recovered from 0-20 cm bs. One distal biface fragment with 25 percent cortex was recovered from $20-30 \mathrm{~cm}$ bs. Both tools are manufactured from local, tan chert. Neither specimen exhibited sufficient qualities to place them within a chronological framework.

\section{Debitage}

A total of 20 debitage was recovered during the 1998 survey and 2000 testing efforts at 41LR152. Of these, four are from the earlier work and the remainder from the 2000 testing. Of this total, eight are chert, one is novaculite, one is silicified wood, and ten are quartzite. Among the assemblage, three chert flakes, one silicified wood flake, and two quartzite flakes are heat-treated. This pattern suggests that, minimally, thermal alteration of stone raw materials to improve workability may have been of low importance at this site.

As at all of the sites in this study, chert and quartzite clearly dominate the debitage total. Of the eight chert flakes, five are decorticate, two have 1-50\% cortex, and one has $100 \%$ cortex. The mean thickness to length ratio for the chert debitage is 0.21 . Of the ten quartzite flakes, five are decorticate, two have $1-50 \%$ cortex, two have $51-99 \%$ cortex, and one has $100 \%$ cortex. The mean thickness to length ratio for the quartzite debitage is 0.24 . These patterns indicate that the primary lithic activity, as reflected by the recovered debitage, was middle stage reduction and tool production.

An itemization of the flake types among the chert debitage presents two core flakes, two core preparation flakes, one platform preparation flake, and three indeterminate flakes. Among the quartzite, there are five core preparation flakes, two platform preparation flakes, one angular debris, and two indeterminate flakes. These comparisons further indicate tool manufacture as the primary activity represented in the lithic assemblage.

Debitage was encountered from $0-80 \mathrm{~cm}$ bs, with the greatest density (46\%) of flakes recovered within levels five and six, or 40-60 cm bs. A second peak of approximately $38 \%$ of the total debitage was encountered in levels one and two, or 0-20 cm bs. Based upon the vertical distribution of this assemblage, two stratified deposits are indicated, with an intervening zone of low density occurring in levels three and four, or $20-40 \mathrm{~cm}$ bs.

Artifacts produced from non-local raw materials recovered from this site include novaculite. Novaculite is generally associated with the Ouchita Mountains in eastern Oklahoma and western Arkansas.

\section{LR153}

\section{Description}

Site 41LR153 is located in the southwestern portion of the facility approximately $200 \mathrm{~m}$ east of Visor Creek (see Figure 10 in supplement). The site is situated atop an upland landform of Annona series loams at 490-500 ft AMSL. The vegetation community consists of the Schizachyrium scoparium Herbaceous class, providing basically $0 \%$ ground surface visibility.

Two backhoe trenches, two excavation/test units, and 23 shovel tests were excavated to define the site area (Figure 16). Based on these data, the site measures approximately $20 \times 35-\mathrm{m}$, and covers an area of about 720 square meters. Ten shovel tests were excavated within the site boundary, eight $(80 \%)$ of which were positive. Cultural material extends from $0-60 \mathrm{~cm}$ bs, with the greatest density (36\%) of provenienced artifacts encountered within levels one and two, or 0-20 cm bs. 


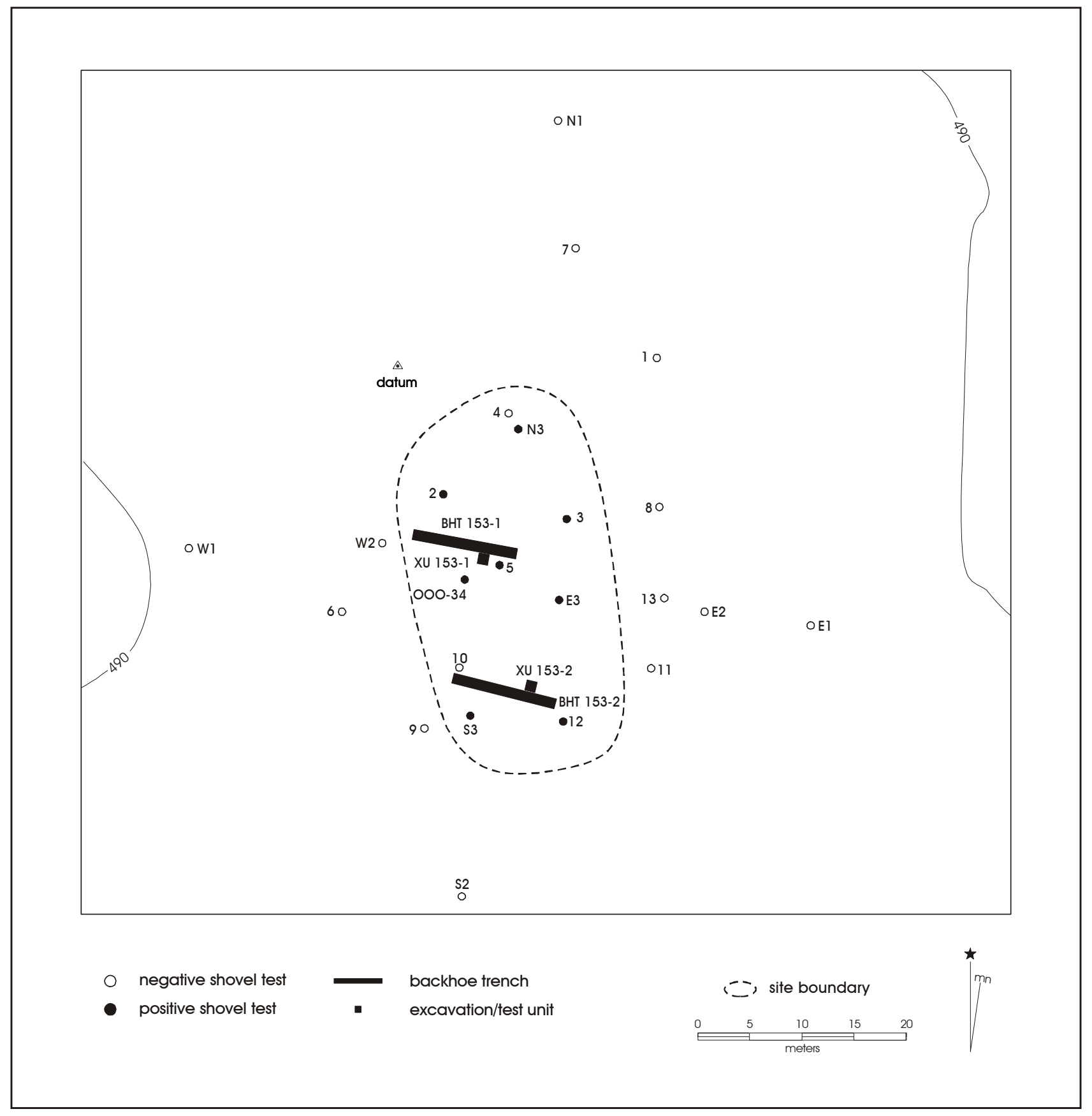

Figure 16. Site map - 41LR153. 


\section{Discussion}

Sparse artifacts recovered from the survey phase include a serrated, corner-notched arrow point fragment, few burned rock fragments, and no ceramics, suggesting a short-term open campsite. Artifactual material recovered during the current phase of investigations was similar in quantity per excavated area, with only 28 burned rocks and 37 lithic debitage. As in the survey phase, cultural material did not extend below 60 $\mathrm{cm}$ bs. Further, no diagnostic artifacts or native ceramics were encountered. Of note, however, was the recovery of a complete quartz crystal from $40-50 \mathrm{~cm}$ bs within XU 1 A possible origin for this crystal, one of only three recovered throughout the project area, would be from the Ouchita Mountains located in eastern Oklahoma and western Arkansas (Banks 1984:92).

\section{Cultural Material}

\section{Native Ceramics}

No ceramics were recovered during either phase of investigations.

\section{Lithics}

\section{Tools}

A single tool was recovered at 41LR153. An untypeable arrow point (Cat. No. 14-1) was recovered at $0-20 \mathrm{~cm}$ bs. The point is manufactured of a green and black mottled chert, probably originating from the Ouchita Mountains. The point lacks a diagnostic stem and exhibits prominent lateral serration. This single specimen suggests the site was used sometime during the Late Prehistoric Caddoan period.

\section{Debitage}

A total of 37 pieces of debitage were recovered during the 1998 survey and 2000 testing efforts at 41LR153. Four of these are from the earlier work while the remainder $(n=33)$ are from the 2000 field season. Of these 37 , nine are chert, one is novaculite, one is silicified wood, and 26 are quartzite. Among the assemblage, one chert flake, one silicified wood flake, and four quartzite flakes are heat-treated. This pattern suggests that, minimally, thermal alteration of stone raw materials to improve workability may have been of low importance at this site.

As at all of the sites in this study, chert and quartzite clearly dominate the debitage total. Of the nine chert flakes, six are decorticate, one has 51-99\% cortex, and two have $100 \%$ cortex. The mean thickness to length ratio for the chert debitage is 0.20 , which is suggestive of middle reduction stage and tool production. Of the 26 quartzite flakes, 14 are decorticate, four have 1-50\% cortex, four have $51-99 \%$ cortex, and four have $100 \%$ cortex. The mean thickness to length ratio for the quartzite debitage is 0.26 , which is suggestive of early stage reduction.

An itemization of the flake types among the chert debitage presents one biface manufacture flake, one biface thinning flake, five core preparation flakes, and two indeterminate flakes. Among the quartzite, there are 15 core preparation flakes, five platform preparation flakes, and six indeterminate flakes. These comparisons further indicate tool manufacture as the primary activity represented in the lithic assemblage.

Debitage was encountered from $0-60 \mathrm{~cm}$ bs, with the greatest density (41\%) of flakes recovered within levels one and two, or 0-20 cm bs. Debitage density gently tapers off in levels three through six $(20-60 \mathrm{~cm}$ bs), with an abrupt termination below $60 \mathrm{~cm}$ bs. Based upon the vertical distribution of this assemblage, no definable stratification of discrete cultural deposits is evident.

Artifacts produced from non-local raw materials recovered from this site include novaculite and green cherts. Novaculite is generally associated with the Ouchita Mountains in eastern Oklahoma and western Arkansas. Green chert is typically related to Oklahoma and may be encountered in Red River gravels. 


\section{LR155}

\section{Description}

Site 41LR155 is located in the southwestern portion of the facility occupying an interfluve of two unnamed tributaries of Visor Creek (see Figure 10 in the supplement). The site is situated atop an upland landform of Annona series loams at 510-520 ft AMSL. The vegetation community consists of the Quercus stellata-Quercus marilandica-(Carya texana) Woodland class, providing roughly $20 \%$ ground surface visibility.

Two excavation/test units and 13 shovel tests were excavated to define the site (Figure 17). Based on these data, the site measures approximately 15 x 40-m, and covers an area of approximately 600 square meters. A total of ten shovel tests were excavated within the current site boundary. Of these ten, seven (70\%) were positive. Cultural material extends from $0-90 \mathrm{~cm} \mathrm{bs}$, with the greatest density (32\%) of provenienced artifacts encountered within levels three and four, or $20-40 \mathrm{~cm}$ bs.

\section{Discussion}

The original survey efforts consisted of nine shovel tests, recovering numerous lithic flakes and a single Talco arrow point. Located atop an upland interfluvitile ridge along the southern facility boundary, the site is naturally delimited to the west, north, and east by two unnamed, intermittent tributaries of Visor Creek and to the south by Gate Two County Road (Figure 17). The construction and continued use of this road has probably destroyed the southern extent of the site, as the continuance of the upland ridge is evident along the southern right-of-way of the roadway corridor.

Three additional shovel tests were excavated on the landform to determine placement of excavation/test units. A single bifacial tool was recovered from ST 1, located approximately $5 \mathrm{~m}$ north of the previously recovered Talco point locus. Accordingly, two 1- $\mathrm{m}^{2}$ units were placed adjacent to these two positive shovel tests in this, the apparent densest portion of the site.
During the investigations, 75 pieces of unmodified debitage and 51 fragments of burned rock were recovered, with mean depths of recovery being $35 \mathrm{~cm}$ bs and $41 \mathrm{~cm}$ bs, respectively. Additionally, a single Gary dart point was recovered within level eight (70-80 $\mathrm{cm}$ bs) of XU 155-1. The testing efforts failed to recover any native pottery sherds, and with the relatively sparse recovery of burned rock, the site is interpreted as a multi-component, short-term prehistoric open campsite.

A surface scatter of early to mid-twentieth century debris occurs immediately west of the site bounds, continuing along the south-southeasterly extent of the meandering finger ridge toward Gate Two County Road. The surface debris consists of large, unidentifiable metal fragments, concrete blocks, tin cans, and early screw-top bottles. As depicted on the 1936 Lamar County map (Texas State Department of Highways and Public Transportation), the nearest recorded historic structure is located approximately $400 \mathrm{~m}$ due east of the ridge along Gate Two County Road (see Figure 11 in supplement).

\section{Cultural Material}

\section{Native Ceramics}

No ceramics were recovered during either phase of investigations.

\section{Lithics}

\section{Tools}

Four tools were recovered during survey and testing efforts at 41LR155. The collection consists of a Talco arrow point, a Gary dart point, a distal biface fragment, and a core. A complete Talco arrow point was recovered from a shovel test (ST WWW-43; Figure 17) at $60-80 \mathrm{~cm}$ bs. The Talco point is a triangular form with symmetrical, serrated concave blades, a deeply concave base, and expanding, downward pointing barbs. It is manufactured of local tan chert and is probably from a relatively small cobble. Indication of near-cortical material (typically red for this local tan chert) exists along the proximal barb tips and the distal blade tip. A complete Gary dart point was recovered nearby in an excavation unit (XU 1; Figure 17) at $70-80 \mathrm{~cm}$ bs. The Gary is smallish in 


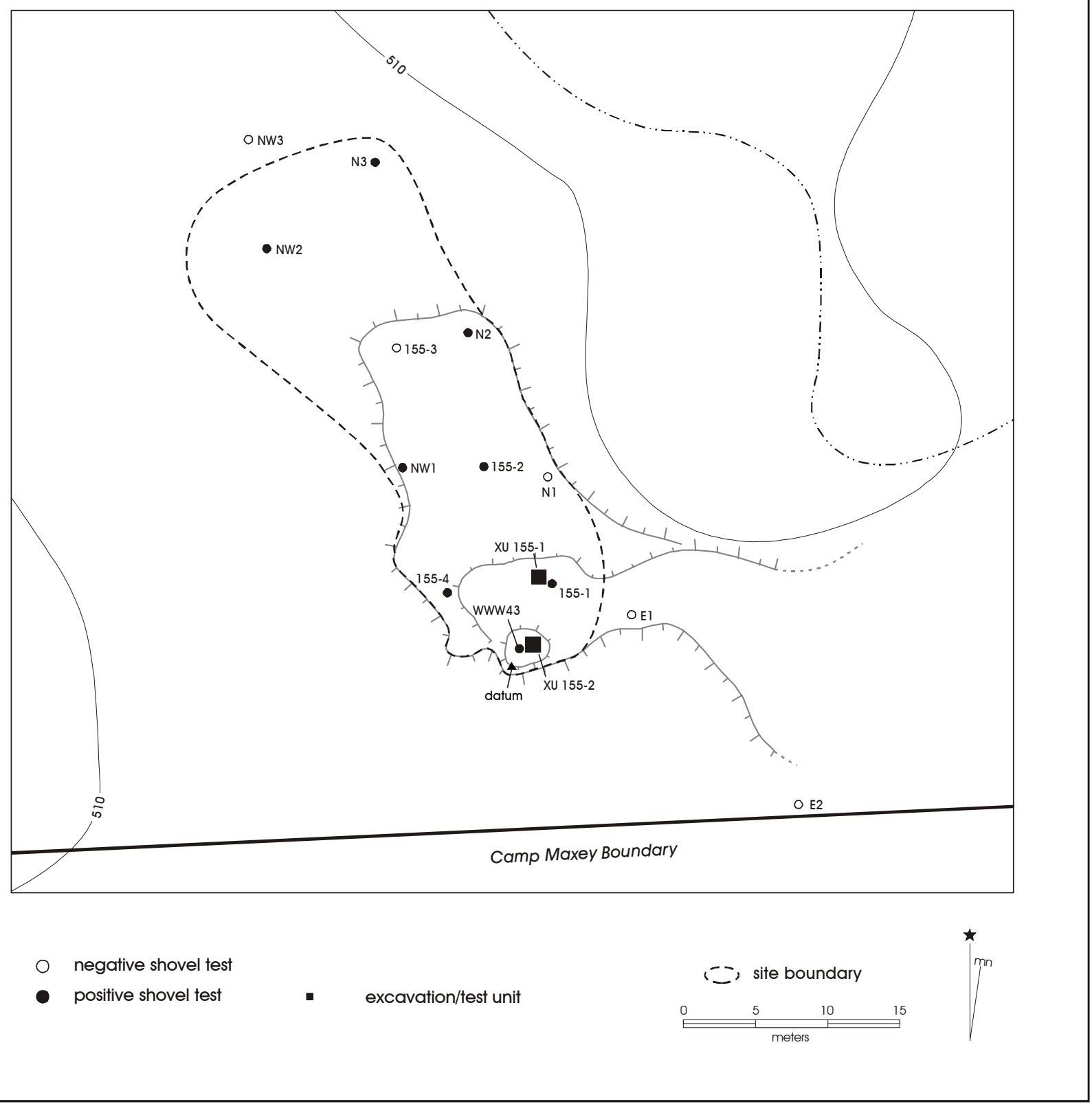

Figure 17. Site map - 41LR155.

size for a dart point, with a diminutive blade length of only $13.7 \mathrm{~mm}$. It has a contracting stem with a rounded base and short barbs that are slightly downward pointing. One of the barbs exhibits a tip break, suggestive of a use break. The dart point is similarly manufactured from tan chert, albeit from a more crude material than the delicate Talco. The distal biface fragment is from a heat-treated, coarse-grained quartzite early stage reduction biface and is untypeable. The core is a tested cobble of silicified wood.

While generally characteristic of the Archaic era, smaller Gary dart points are suggested to occur alongside early ceramics and early, expanding stem arrow points of the Woodland period (Perttula et al. 1993:101). Due to its recovery from a $20-\mathrm{cm}-l e v e l$ in 
a shovel test, it is unclear whether the Talco is stratigraphically situated above the Gary. Regardless, these artifacts suggest the site may have been occupied during the Woodland and/or the Late Prehistoric Caddoan periods.

\section{Debitage}

A total of 75 debitage was recovered during the 1998 survey and 2000 testing efforts at 41LR155. Of this total, 17 are chert, two are silicified wood, and 56 are quartzite. Among the assemblage, two chert flakes and 21 quartzite flakes are heat-treated. This pattern suggests that, minimally, thermal alteration of stone raw materials to improve workability may have been of low importance at this site.

Chert and quartzite clearly dominate the debitage total. Of the 17 chert flakes, 15 are decorticate and two have $1-50 \%$ cortex. The mean thickness to length ratio for the chert debitage is 0.14 . This pattern is indicative of late stage reduction and/or tool rejuvenation/resharpening. Of the 56 quartzite flakes, 31 are decorticate, 15 have $1-50 \%$ cortex, four have $51-99 \%$ cortex, and six have $100 \%$ cortex. The mean thickness to length ratio for the quartzite debitage is 0.18 . This pattern indicates middle stage reduction and tool production.

Itemization of the flake types among the chert debitage presents two biface manufacture flakes, seven core preparation flakes, one platform preparation flake, and seven indeterminate flakes. Among the quartzite, there are four biface manufacture flakes, 22 core preparation flakes, nine platform preparation flakes, and 21 indeterminate flakes. These comparisons further indicate tool manufacture as the primary activity represented in the lithic assemblage.

Debitage was encountered from $0-80 \mathrm{~cm} \mathrm{bs}$, with the greatest density (31\%) of flakes recovered within levels three and four, or $20-40 \mathrm{~cm}$ bs. Debitage density gently tapers off in levels five through eight (40-80 cm bs), with abrupt termination below $80 \mathrm{~cm}$ bs. Based upon the vertical distribution of this assemblage, no definable stratification of discrete cultural deposits is evident.

Artifacts produced from non-local raw materials recovered from this site include gray cherts. The gray cherts are typically associated with the Georgetown cherts of central Texas.

\section{LR156}

\section{Description}

Site 41LR156 is located in the southwestern portion of the facility along the right descending bankline of an unnamed tributary of Visor Creek (see Figure 10 in supplement). The site is situated atop a lower slope landform of Woodtell series loams at 500-520 ft AMSL. The vegetation community consists of the Quercus nigra-Ulmus americana Woodland class, providing roughly $15 \%$ ground surface visibility.

Two excavation/test units and 12 shovel tests were excavated to define the site (Figure 18). Based on these data, the site measures approximately $30 \times 35-\mathrm{m}$ and covers an area of about 1,220 square meters. Five shovel tests were excavated within the current site boundary. All five on-site tests were positive. Cultural material extends from $0-60 \mathrm{~cm}$ bs, with the greatest density $(48 \%)$ of provenienced artifacts encountered within levels three and four, or $20-40 \mathrm{~cm}$ bs.

\section{Discussion}

The site bounds of 41LR156 were originally delimited by the recovery of three lithic flakes, one burned turtle shell, and three burned rocks in shovel tests. The site is located on a sloping terrace along the right descending bankline of an unnamed tributary of Visor Creek and is naturally bound by two upland drainages to the east and west (see Figure 10 in supplement). An abandoned dirt road has probably obliterated the original northern bounds of the site.

Testing of 41LR156 consisted of the excavation of two $50 \mathrm{~cm}^{2}$ units. Due to the relatively shallow sediments, no backhoe trenches were excavated at this site. The excavation units were situated adjacent to the most productive survey shovel tests (NW-1 and UUU-38) in order to explore the densest portion of the site. Recovery included ten additional burned rocks, and 15 additional lithic debitage, with no indication of significant deposits or features. Due to the limited recovery, the site is interpreted as a brief, and possible single, occupation open campsite. 


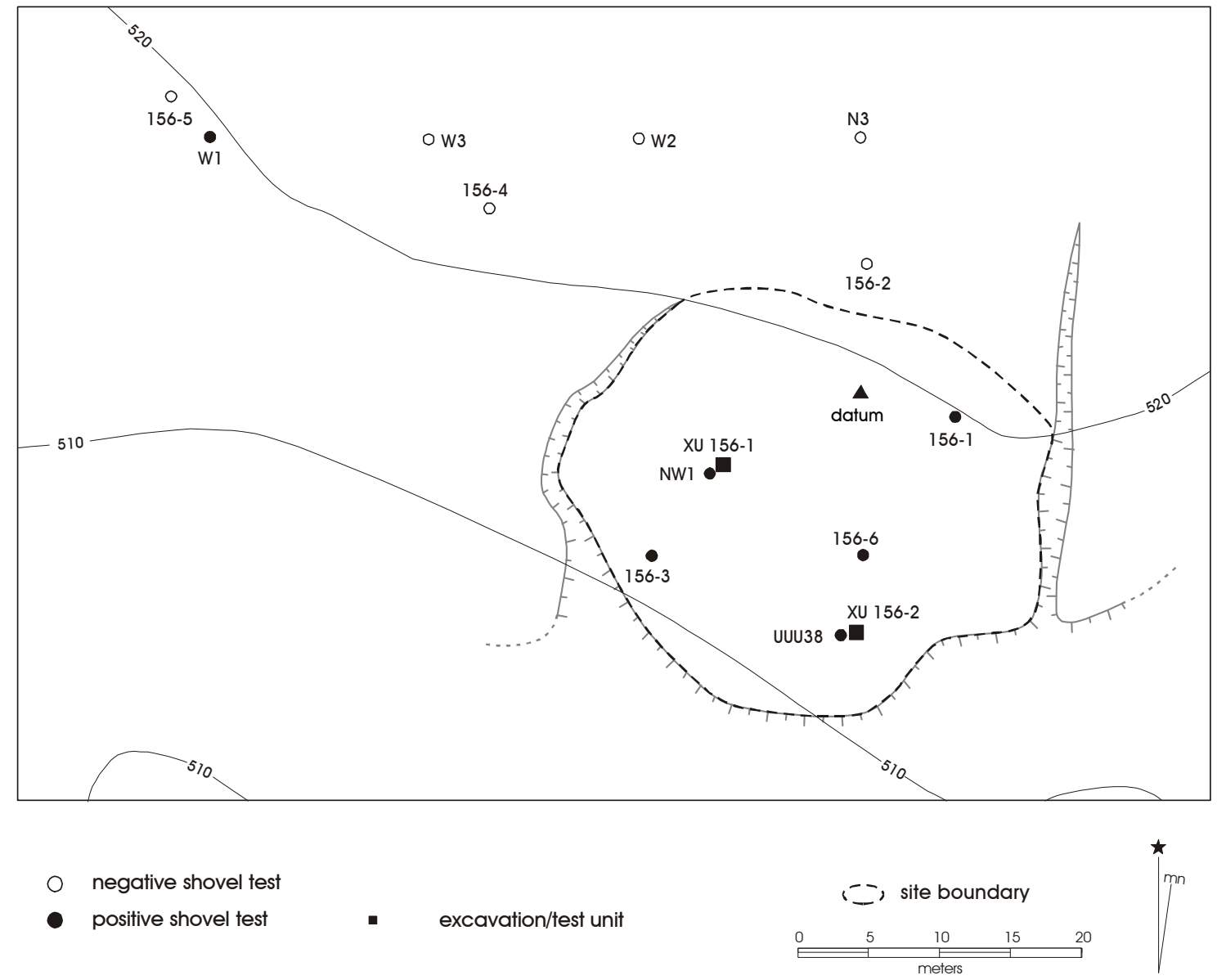

Figure 18. Site map - 41LR156.

\section{Cultural Material}

\section{Native Ceramics}

No ceramics were recovered during either phase of investigations.

\section{Lithics}

\section{Tools}

No stone tools were recovered during either phase of investigations.

\section{Debitage}

A total of 18 debitage was recovered during the 1998 survey and 2000 testing efforts at 41LR156. Of this total, ten are chert and eight are quartzite. Among the assemblage, three chert flakes are heat-treated. This pattern suggests that, minimally, thermal alteration of stone raw materials to improve workability may have been of low importance at this site.

Chert and quartzite clearly dominate the debitage total. Of the ten chert flakes, seven are decorticate, two have $1-50 \%$ cortex, and one has $100 \%$ cortex. The mean thickness to length ratio for the chert debitage is 0.18 . Of the eight quartzite flakes, five are decorticate, two have $1-50 \%$ cortex, and one has $51-99 \%$ cortex. The mean thickness to length ratio for the quartzite debitage is 0.18 . These patterns indicate that the primary lithic activity, reflected by the recovered debitage, was tool manufacture. 
An itemization of the flake types among the chert debitage presents four core preparation flakes, one notching flake, two platform preparation flake, and three indeterminate flakes. Among the quartzite, there are two core preparation flakes and six platform preparation flakes. These comparisons further indicate tool manufacture as the primary activity represented in the lithic assemblage.

Debitage was encountered from $0-60 \mathrm{~cm}$ bs, with the greatest density $(61 \%)$ of flakes recovered within levels one and two, or 0-20 cm bs. Debitage density drops considerably below $20 \mathrm{~cm}$ bs, with only a single flake recovered from $40-60 \mathrm{~cm}$ bs. Based upon the vertical distribution of this assemblage, a cultural zone is indicated from $0-20 \mathrm{~cm}$ bs.

Artifacts produced from non-local raw materials recovered from this site include gray cherts. The gray cherts are typically associated with the Georgetown cherts of central Texas.

\section{LR157}

\section{Description}

Site 41LR157 is located in the southwestern portion of the facility along the right descending bankline of an unnamed tributary of Visor Creek (see Figure 10 in supplement). The site is situated atop an upland landform of Whakana series fine sandy loams at about $510 \mathrm{ft}$ AMSL. The vegetation community consists of the Quercus nigra-Ulmus americana Woodland class, providing roughly $10 \%$ ground surface visibility.

Three excavation/test units and 17 shovel tests were excavated to define the current site boundaries (Figure 19). Based on these data, the site measures approximately $25 \times 40-\mathrm{m}$, and covers an area of about 1025 square meters. Four shovel tests were excavated within the current site boundary. All four on-site tests were positive. Cultural material extends from 0-100 $\mathrm{cm}$ bs, with the greatest density (43\%) of provenienced artifacts encountered within levels one and two, or $0-20 \mathrm{~cm}$ bs.

\section{Discussion}

Immediately north of the probable central portion of this site is the locus for an intersection of two historic dirt roads (see Figure 11 in supplement). The northsouth trending road and east-west trending road have cut an approximately $15-\mathrm{m}$ wide and $10-\mathrm{m}$ wide (respectively) by 1-m deep corridor into the fine sandy loam ground surface, with the former probably obliterating a good portion of the site. Remnants of the site exist around the periphery of the north-south trending road, comprising the remainder of the undisturbed upland ridge. It is estimated that this road has destroyed approximately $27 \%$ of the areal extent of the original site. It cannot be determined, however, to what degree the road has impacted the overall artifact assemblage. 


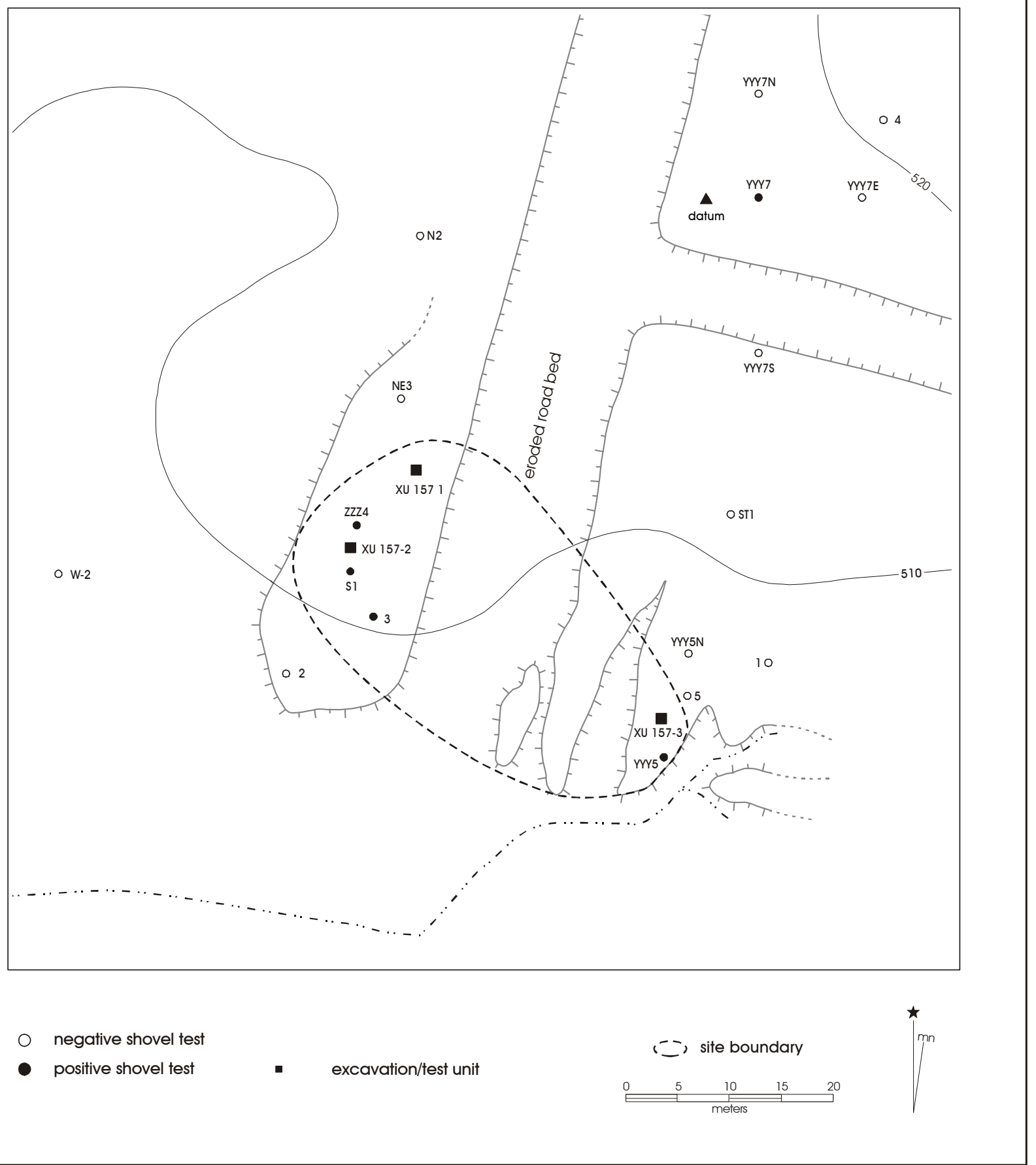

Figure 19. Site map - 41LR157. 


\section{Cultural Material}

\section{Native Ceramics}

\section{Investigations}

Four of the five sherds from the site are plain, and the fifth (from ST ZZZ-4) has a single engraved line of indeterminate orientation. The sherds are from thin $(5.1 \pm 1.1 \mathrm{~mm})$, grog-tempered vessels, although the engraved sherd also has small amounts of finely crushed bone temper. A light reddish-orange core cross section indicates that this sherd is from a vessel that has been fired in an oxidizing environment, while the others are from vessels with dark cores with thin oxidized layers (fired under low-oxygen conditions and cooled in a high-oxygen environment).

\section{Investigations}

There are 12 sherds, two of which are less than $1 \mathrm{~cm}$ in length, collected from 41LR157. The majority of the sherds collected are from the western end of the site, in XU 157-2.

All ten of the sherds large enough for analysis have grog temper; one body sherd also has a sandy paste. The grog-tempered sherds are relatively thin (6.13 \pm $0.98 \mathrm{~mm}$ ), especially compared to the grog-tempered sandy paste ( $7.4 \mathrm{~mm}$ thick), and two have either been smoothed or burnished on exterior surfaces (and are probably from bowls). About half of the sherds are from vessels fired in a reducing environment, including one burnished rim (direct, with a flat lip) from Unit 2 with a single horizontal engraved line $5 \mathrm{~mm}$ below the lip. This sole decorated sherd is consistent with an Early and/or Middle Caddoan period occupation at 41LR157 (see also Nickels et al. 1998).

\section{Lithics}

\section{Tools}

A single bifacial drill was the only tool recovered from 41LR157. The drill appears complete, is lanceolate in form, exhibits alternate beveling, and lacks noticeable use wear. The drill is quite small, measuring only 26.3 $\mathrm{mm}$ long, $7.0 \mathrm{~mm}$ wide, and a maximum thickness of $3.3 \mathrm{~mm}$. The raw material is a light-green, fine-grained chert. The drill is not temporally diagnostic.

\section{Debitage}

A total of 50 pieces of debitage were recovered during the 1998 survey and 2000 testing efforts at 41LR157. Of this total, 17 are chert, one is silicified wood, and 32 are quartzite. Among the assemblage, three chert flakes and 20 quartzite flakes are heattreated. This pattern suggests that, minimally, thermal alteration of stone raw materials to improve workability may have been of moderate importance at this site.

As at all of the sites in this study, chert and quartzite clearly dominate the debitage total. Of the 17 chert flakes, eight are decorticate, five have 1-50\% cortex, three have $51-99 \%$ cortex, and one has $100 \%$ cortex. The mean thickness to length ratio for the chert debitage is 0.21 . Of the 32 quartzite flakes, 14 are decorticate, ten have $1-50 \%$ cortex, and eight have $51-99 \%$ cortex. The mean thickness to length ratio for the quartzite debitage is 0.19 . These patterns indicate that the primary lithic activity, as reflected by the recovered debitage, was tool manufacture.

An itemization of the flake types among the chert debitage presents one angular debris flake, six core preparation flakes, six platform preparation flake, and four indeterminate flakes. Among the quartzite, there are two biface manufacture flakes, one core flake, 11 core preparation flakes, nine platform preparation flakes, one uniface flake, and eight indeterminate flakes. These comparisons further indicate tool manufacture as the primary activity represented in the lithic assemblage.

Debitage was encountered from $0-80 \mathrm{~cm} \mathrm{bs}$, with the greatest density (46\%) of flakes recovered within levels two and three, or $20-40 \mathrm{~cm}$ bs. Debitage density drops considerably below $40 \mathrm{~cm}$ bs, with only four flakes recovered from $40-60 \mathrm{~cm}$ bs and only two flakes recovered from $60-80 \mathrm{~cm}$ bs. Based upon the vertical distribution of this assemblage, a cultural zone is indicated from $20-40 \mathrm{~cm}$ bs.

Artifacts produced from non-local raw materials recovered from this site include green cherts and gray cherts. The green cherts are typically related to Oklahoma and may be encountered in Red River gravels. The gray cherts are typically associated with the Georgetown cherts of central Texas. 


\section{LR158}

\section{Description}

Site 41LR158 is located in the southwestern portion of the facility approximately $150 \mathrm{~m}$ west of Visor Creek (see Figure 10 in supplement). The site is situated atop an upland landform of Whakana series fine sandy loams at 520-530 ft AMSL. The vegetation community consists of the Schizachyrium scoparium Herbaceous class, providing roughly $50 \%$ ground surface visibility.

Four backhoe trenches, one excavation unit and 19 shovel tests were excavated to define the site boundary (Figure 20). Based on these data, the site measures approximately $70 \times 55-\mathrm{m}$, and covers an area of roughly 2,760 square meters. A total of five shovel

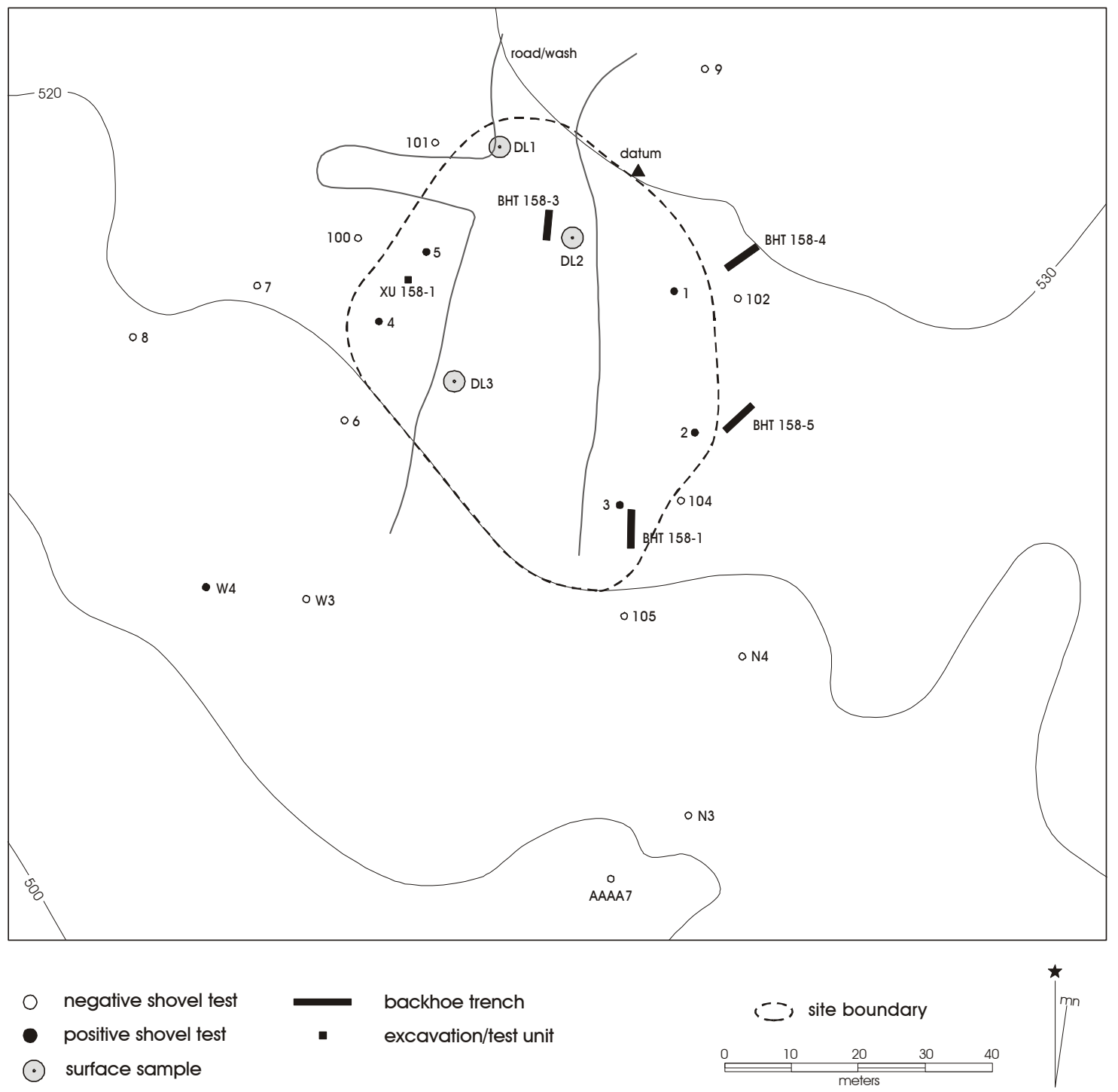

Figure 20. Site map - 41LR158. 
tests were excavated within the site boundary. All five were positive. Cultural material extends from 0-40 $\mathrm{cm}$ bs, with the greatest density (69\%) of provenienced artifacts found in levels one and two, or 0-20 cm bs.

In addition, all surface chipped lithics and a representative sample of raw materials were collected from three surface sample (DL) areas. Each surface sample collection area measured $3 \mathrm{~m}$ in diameter.

\section{Discussion}

The improved ground surface visibility encountered at this site is attributable to recent military vehicle activity in the area. Specifically, the use of two tracks diverging to the south and west of the site centrum have destroyed the natural vegetation and accelerated surface erosion, exposing the upland gravel deposit. The gravels are overlain by $5-10 \mathrm{~cm}$ of sandy sediments and immediately underlain by basal clays. The deposit, with an estimated composition of $85 \%$ quartzite and $15 \%$ cherts, averages roughly $15 \mathrm{~cm}$ in thickness across the site. Raw material ranges in size from pea-gravels to large (10-15 cm diameter) cobbles.

This site probably served as a raw material source for surrounding sites such as 41LR155, 41LR156, 41LR157, and possibly 41LR164. Accordingly, no occupational features were anticipated, nor encountered during the testing phase. Indication of deflated features such as lithic reduction stations are suggested by the surface expression of lithic scatters and failed tool fragments. No temporally diagnostic stone tools were recovered from the site; however, a complete Dalton dart point was recovered approximately 150 $m$ due east of the site.

\section{Cultural Material}

\section{Native Ceramics}

No ceramics were recovered during either phase of investigations.

\section{Lithics}

\section{Tools}

Nine stone tools were recovered from 41LR158; none of which are temporally diagnostic. Two untypeable biface fragments were recovered at $0-20 \mathrm{~cm}$ bs. The biface fragments, one a proximal fragment and one a distal fragment, are both manufactured of heat-treated gray chert. The proximal fragment exhibits heavy bifacial thinning and is probably a dart point stem, but it lacks enough characteristics to label it as such. The remainder of the tools in this assemblage is comprised of quartzite cores. Most of the cores are typical medium-grained gray quartzites, which have proven to be quite workable after proper heat-treatment (see 41LR164, below). All of the provenienced tools occur between $0-20 \mathrm{~cm}$ bs.

The nearby, complete Dalton dart point (Figure 21) is reworked, as evidenced by the alternate beveling along the blades. The Dalton is manufactured from a gray chert and has a high luster.

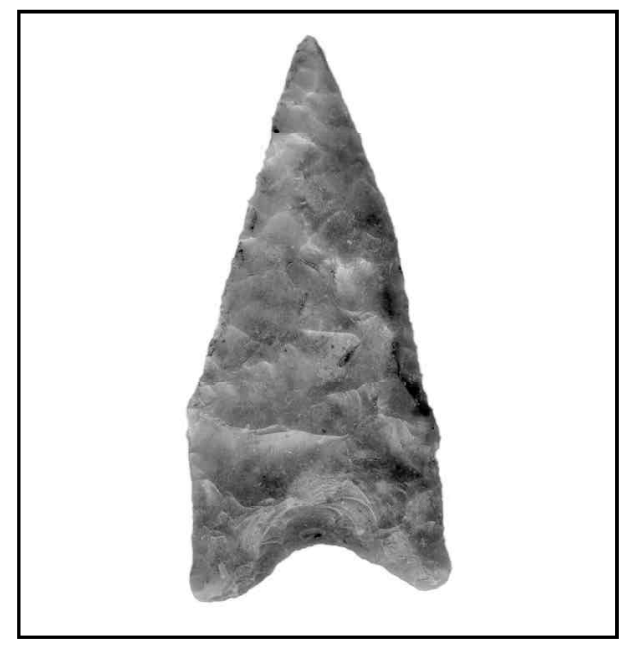

Figure 21. Dalton dart point recovered at ground surface $\sim 150 \mathrm{~m}$ east of $41 L R 158$.

\section{Debitage}

A total of 66 debitage was recovered during the 1998 survey and 2000 testing efforts at 41LR158. Of this total, three are chert, three are silicified wood, 59 are quartzite, and one is jasper. Among the assemblage, one chert flake and 30 quartzite flakes are heat-treated. This pattern suggests that, minimally, thermal alteration of stone raw materials to improve workability may have been of moderate importance at this site. 
As at all of the sites in this study, chert and quartzite clearly dominate the debitage total. Of the three chert flakes, two have $1-50 \%$ cortex and one has $51-99 \%$ cortex. The mean thickness to length ratio for the chert debitage is 0.27 . Of the 59 quartzite flakes, eight are decorticate, 21 have $1-50 \%$ cortex, 14 have $51-99 \%$ cortex, and 16 have $100 \%$ cortex. The mean thickness to length ratio for the quartzite debitage is 0.25 . These patterns indicate that the primary lithic activities, as reflected by the recovered debitage, were early stage reduction and procurement.

An itemization of the flake types among the chert debitage presents two core preparation flakes and one platform preparation flake. Among the quartzite, there are 35 core preparation flakes, 15 platform preparation flakes, and nine indeterminate flakes. These comparisons further indicate tool manufacture and procurement as the primary activities represented in the lithic assemblage.

Debitage was encountered from 0-60 cm bs, with the greatest density (73\%) of flakes recovered within levels one and two, or 0-20 cm bs. Debitage density drops considerably below $20 \mathrm{~cm}$ bs, with only 12 flakes recovered from $20-40 \mathrm{~cm}$ bs and only five flakes recovered from $40-60 \mathrm{~cm}$ bs. Based upon the vertical distribution of this assemblage, no definable stratification of discrete cultural deposits is evident.

Artifacts produced from non-local raw materials recovered from this site include gray cherts. The gray cherts are typically associated with the Georgetown cherts of central Texas.

\section{LR160}

\section{Description}

Site 41LR160 is located in the southwestern portion of the facility along the left descending bankline of an unnamed tributary of Visor Creek (see Figure 10 in supplement). The site is situated atop an upland landform of Whakana-Porum series loams at 500-510 ft AMSL. The vegetation community consists of the Quercus stellata-Quercus marilandica-(Carya texana) Woodland class, providing roughly $15 \%$ ground surface visibility.

Three backhoe trenches, three excavation units, and 30 shovel tests were excavated to define the site area (Figure 22). Based on these data, the site measures approximately $60 \times 50-\mathrm{m}$, and covers an area of about 2,875 square meters. Twelve shovel tests were excavated within the current site boundaries. Eleven (92\%) of these on-site shovel tests were positive. Cultural material extends from $0-80 \mathrm{~cm}$ bs, with the greatest density $(43 \%)$ of provenienced artifacts encountered within levels three and four, or $20-40 \mathrm{~cm}$ bs.

\section{Discussion}

A portion of the testing efforts focused upon the recovery of materials recovered during the testing phase in two shovel tests along the unnamed tributary. A single backhoe trench was placed adjacent to shovel tests E1 and E2 in an attempt to locate the possible feature suggested by the recovery of several burned rocks in Shovel Test E2. No indication of cultural material was encountered with mechanical excavations, however.

Shovel tests excavated south of E1 and E2 indicate a continuation of the scatter of cultural material, recovering additional burned rock and lithic debitage. Two other backhoe trenches with associated excavation units were placed within the cluster of positive shovel tests. Additionally, a stand-alone excavation unit was placed between the backhoe trenches and immediately adjacent a positive shovel test (ST 6). The mechanical and manual efforts both failed to produce any indication of significant deposits or features. 


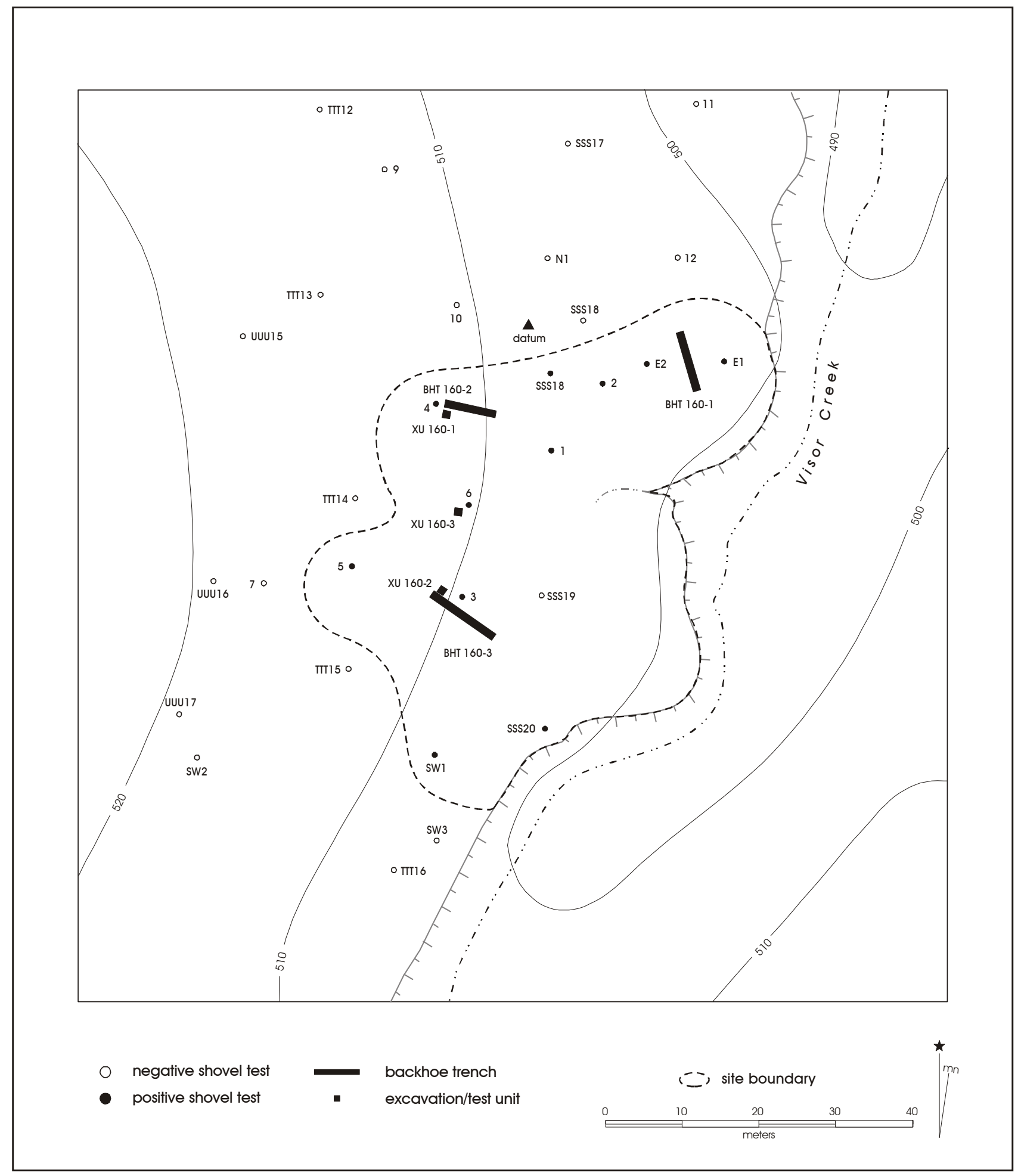

Figure 22. Site map-41LR160. 


\section{Cultural Material}

\section{Native Ceramics}

No ceramics were recovered during either phase of investigations.

\section{Lithics}

\section{Tools}

A single core was the only tool recovered from 41LR160. The core is manufactured of a mediumgrained gray quartzite, with $10 \%$ cortex remaining. It was recovered from an excavation unit (XU 160-2; Figure 22) at $30-40 \mathrm{~cm}$ bs. The core is not temporally diagnostic.

\section{Debitage}

A total of 27 debitage was recovered during the 1998 survey and 2000 testing efforts at 41LR160. Of this total, four are chert, two are novaculite, one is silicified wood, 19 are quartzite, and one is jasper. Among the assemblage, one chert flake and one quartzite flake are heat-treated. This pattern suggests that, minimally, thermal alteration of stone raw materials to improve workability may have been of low importance at this site.

As at all of the sites in this study, chert and quartzite clearly dominate the debitage total. Of the four chert flakes, three are decorticate and one has 51-99\% cortex. The mean thickness to length ratio for the chert debitage is 0.14 , which indicates late stage reduction and tool resharpening. Of the 19 quartzite flakes, seven are decorticate, nine have $1-50 \%$ cortex, two have $51-99 \%$ cortex, and one has $100 \%$ cortex. The mean thickness to length ratio for the quartzite debitage is 0.25 . This pattern is indicative of middle stage reduction and tool manufacture.

An itemization of the flake types among the chert debitage presents one core preparation flake, one platform preparation flake, and two indeterminate flakes. Among the quartzite, there are nine core preparation flakes, five platform preparation flakes, and five indeterminate flakes. These comparisons further indicate tool manufacture as the primary activity represented in the lithic assemblage.

Debitage was encountered from $0-80 \mathrm{~cm}$ bs, with the greatest density (44\%) of flakes recovered within levels three and four, or 20-40 cm bs. Debitage density drops considerably below $40 \mathrm{~cm}$ bs, with only two flakes recovered from $40-60 \mathrm{~cm}$ bs and only five flakes recovered from $60-80 \mathrm{~cm}$ bs. Based upon the vertical distribution of this assemblage, a cultural zone is indicated from $20-40 \mathrm{~cm}$ bs.

Artifacts produced from non-local raw materials recovered from this site include novaculite, green cherts and gray cherts. Novaculite is generally associated with the Ouchita Mountains in Eastern Oklahoma and Western Arkansas. The green cherts are typically related to Oklahoma and may be encountered in Red River gravels. The gray cherts are typically associated with the Georgetown cherts of central Texas. 


\section{LR163}

\section{Description}

Site 41LR163 is located in the southwestern portion of the facility along the right descending bankline of Visor Creek (see Figure 10 in supplement). The site is situated atop an upland landform of Lassiter series silt loams at $490 \mathrm{ft}$ AMSL. The vegetation community consists of the Quercus nigra-Ulmus americana Woodland class, providing roughly $5 \%$ ground surface visibility.

Two excavation units, and 13 shovel tests were excavated to define the site boundaries (Figure 23). Based on these data, the site measures approximately $8 \times 10-\mathrm{m}$, and covers roughly 150 square meters. A total of six shovel tests were excavated on-site, five (83\%) were positive. Cultural material extends from $0-80 \mathrm{~cm} \mathrm{bs}$, with the greatest density $(71 \%)$ of provenienced artifacts encountered within levels three and four, or $20-40 \mathrm{~cm}$ bs.

\section{Discussion}

The site is wholly contained within the riparian zone bordering Visor Creek. Large oak and elm are complemented with thick secondary understory vegetation. The presence of abundant roots, here as well as at a majority of the sites within the project area, has been noted. The root systems do not extend vertically into the clay substrate; rather, they grow horizontally throughout the depth of the coarser deposits. With a relatively shallow zone of deposition (less than $80 \mathrm{~cm}$ ), this allocates proliferous root activity/disturbance within a small area over a significant period of time. This, coupled with rodent and insect activity, suggests a very low probability for intact features to be encountered. The presence of roughly three-fourths of the artifact assemblage within two, 10-cm arbitrary levels across the site indicates that the original ground surface during human occupation of 41LR163 was somewhere between $20-40 \mathrm{~cm}$ bs.

\section{Cultural Material}

\section{Native Ceramics}

No ceramics were recovered in the survey portion of this project.

\section{Investigations}

One sherd, less than $1 \mathrm{~cm}$ in size, was collected from Unit $1(10-20 \mathrm{~cm} \mathrm{bs})$. This very limited ceramic evidence suggests the site was used during either the Woodland or Late Prehistoric Caddoan periods.

\section{Lithics}

\section{Tools}

A dart point, a biface fragment and two edge-modified flakes comprise the recovered tool assemblage of 41LR163. A Gary dart point is represented by the recovery of a proximal fragment at $60-70 \mathrm{~cm}$ bs in an excavation unit (XU 1; Figure 23). The dart point fragment has a contracting stem with a rounded base. The point is manufactured from a fine-grained gray quartzite. It is interesting to note the presence of cortex on the most proximal portion of the rounded base. The depth of recovery of this point, relative to the shallow nature of the single ceramic sherd at $10-20 \mathrm{~cm} \mathrm{bs}$, would suggest an earlier, Archaic component to the Woodland or Late Prehistoric component indicated by the ceramic. The biface fragment is untypeable and is also manufactured from a fine-grained gray quartzite. The fragment was recovered within the same unit as the Gary at $50-60 \mathrm{~cm}$ bs. The remaining two tools, both edge-modified flakes, are expedient scrapers and have been heat-treated. Depth of recovery for the edgemodified flakes ranges from $20-60 \mathrm{~cm}$ bs.

\section{Debitage}

A total of 33 debitage was recovered during the 1998 survey and 2000 testing efforts at 41LR163. Of this total, five are chert, one is silicified wood, and 27 are quartzite. Among the assemblage, nine quartzite flakes are heat-treated. This pattern suggests that, minimally, thermal alteration of stone raw materials to improve workability may have been of low importance here.

As at all of the sites in this study, chert and quartzite clearly dominate the debitage total. Of the five chert flakes, two are decorticate and three have $1-50 \%$ cortex. The mean thickness to length ratio for the chert debitage is 0.15 . Of the 27 quartzite flakes, 16 are decorticate, eight have 1-50\% cortex, one has $51-99 \%$ cortex, and two have $100 \%$ cortex. The mean thickness to length ratio for the quartzite debitage is 0.21 . These patterns indicate that the primary lithic activity, as reflected by the recovered debitage, was 
middle to late stage reduction tool manufacture and tool rejuvenation.

An itemization of the flake types among the chert debitage presents one biface thinning flake, two core preparation flakes, and two indeterminate flakes. Among the quartzite, there are seven core preparation flakes, nine platform preparation flakes, one biface manufacture flake, and ten indeterminate flakes. These comparisons further indicate tool manufacture as the primary activity represented in the lithic assemblage.
Debitage was encountered from $0-80 \mathrm{~cm}$ bs, with the greatest density $(67 \%)$ of flakes recovered within levels three and four, or $20-40 \mathrm{~cm}$ bs. Debitage density drops considerably below $40 \mathrm{~cm}$ bs, with only five flakes recovered from $40-60 \mathrm{~cm}$ bs and only one flake recovered from $60-80 \mathrm{~cm}$ bs. Based upon the vertical distribution of this assemblage, a cultural zone is indicated from $20-40 \mathrm{~cm}$ bs.

Artifacts produced from non-local raw materials recovered from this site include gray cherts. The gray cherts are typically associated with the Georgetown cherts of central Texas.

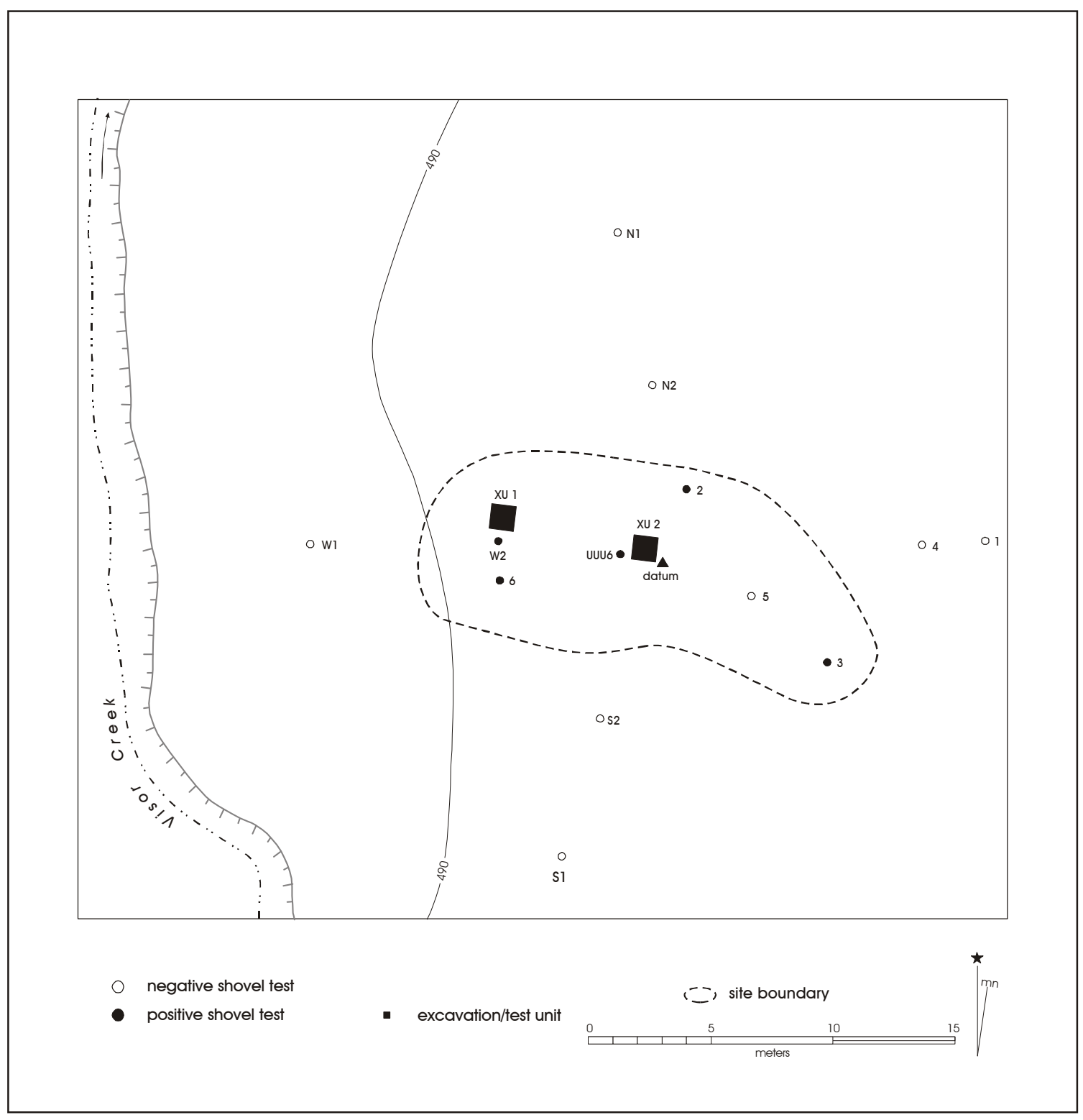

Figure 23. Site map - 41LR163. 


\section{LR164}

\section{Description}

Site 41LR164 is located in the southwestern portion of the facility along the left descending bankline of Visor Creek (see Figure 10 in supplement). The site is situated atop an upland landform of Whakana-Porum series loams at 500-530 ft AMSL. The vegetation community consists of the Quercus nigra-Ulmus americana Woodland class, providing roughly $15 \%$ ground surface visibility.

Nine backhoe trenches, seven excavation units, and 131 shovel tests were excavated to define the site boundary (Figure 24). Based on these data, the site measures approximately $270 \times 130-\mathrm{m}$ and covers an area of about 34,570 square meters. A total of 105 shovel tests were excavated within the current site boundary, 27 (26\%) of which were positive. Cultural material extends from $0-60 \mathrm{~cm}$ bs, with the greatest density $(43 \%)$ of provenienced artifacts encountered within levels three and four, or $20-40 \mathrm{~cm}$ bs.

\section{Discussion}

This site was originally mapped as the largest prehistoric site on the Camp Maxey facility, approximately $378,000 \mathrm{~m}^{2}$, and delimited into two areal concentrations. An additional 82 shovel tests were excavated during the testing phase to further examine the spatial extent of the site bounds. Specifically, additional shovel tests were excavated, spaced $10-\mathrm{m}$ in each cardinal direction, around previously excavated positive shovel tests. Based upon the results of additional shovel tests, backhoe trenches, and excavation units, a central concentration of cultural material has been defined as an area 50-m long and 40-m wide, or $2,000 \mathrm{~m}^{2}$, contained within the southeastern portion of the original "Area B" designation (Nickels et al. 1998:Figure 8-19). Indeed, three projectile points (Figure 25) were recovered within this dense area.

The remainder of the original site bounds should not be discounted; however, a further analysis of the context in which the outlier cultural material was recovered is appropriate. A vast majority (over 76\%) of the material recovered from shovel tests occurred within the first level $(0-20 \mathrm{~cm} \mathrm{bs})$ of excavation, and only $6 \%$ of the material recovered from shovel tests occurred within the zone of greatest recovery (40-60 cm bs) for the central concentration of cultural material. This variability could indicate varying activity areas, discrete occupations, or remnants of sites disturbed by military activity. With the lack of temporally diagnostic artifacts recovered from the outlier areas, it cannot be determined whether they are contemporaneous with the central concentration of cultural material.

A single feature was encountered at $30-40 \mathrm{~cm}$ bs in XU 1 (Figure 26). The feature is a concentration of burned sandstone originally identified in the eastern wall of BHT 2. Upon excavation, and as depicted in Figure 26, it was evident that the backhoe had removed a significant portion of the feature. A remnant portion of the feature was left, and several samples of the burned sandstone were collected. No charcoal was encountered in direct association with the feature.

Sediment susceptibility samples were collected and processed for XU 1. As discussed in Appendix B (see also Gose and Nickels 2001 [1998]), mass-specific sediment susceptibility values can provide indications of buried surfaces, especially those associated with charcoal and ash that results from cultural activities conducted on those surfaces, by measuring the magnetic potential of the sediments. High magnetic potential can result from a variety of elements, including concentrations of organic material and ash. While, in the case of the samples from Camp Maxey, any specific interpretation is complicated by the presence of ferrous particles in the soil which can result in extremely high values (Appendix B), the presence of significant increases in soil susceptibility values for a given profile can provide critical data for identifying buried surfaces associated with prehistoric occupation.

For XU 1, five samples were collected at 10 -cm intervals from 0 to $50 \mathrm{~cm}$ bs. As discussed in Appendix B, the values provided by the samples from this unit indicate an increase in the value associated with Level 4 (30-40 cm bs). The co-occurrence of this spike in the value with the Feature 1 level for this excavation unit hints that the feature may have been associated with a buried occupation surface. 


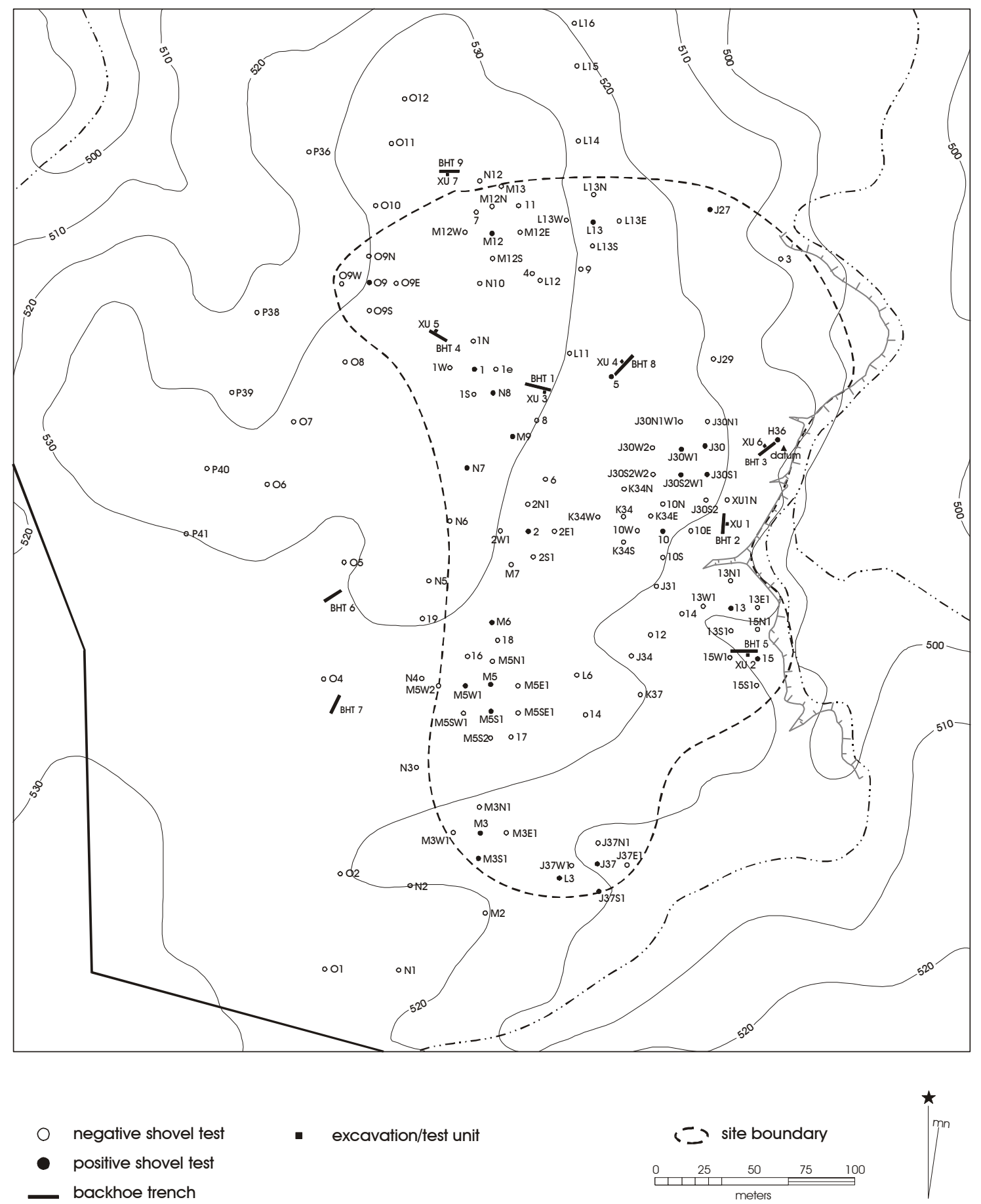

Figure 24. Site map - 41LR164. 


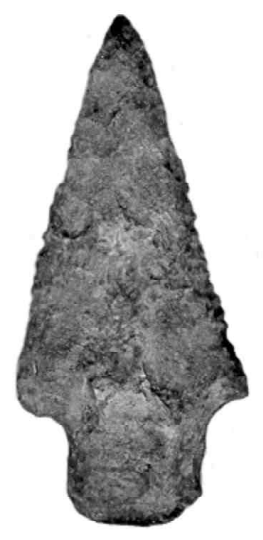

LR164a

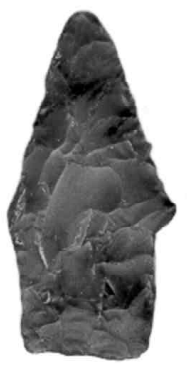

LR1 70

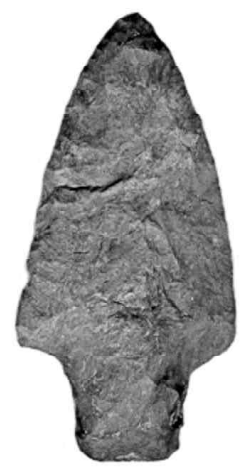

LR164b

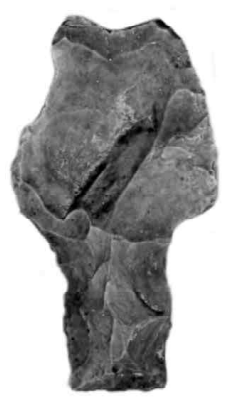

LR164C

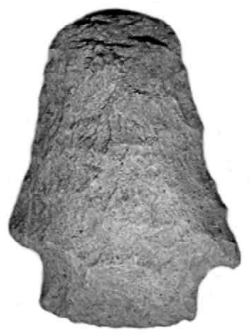

LR187

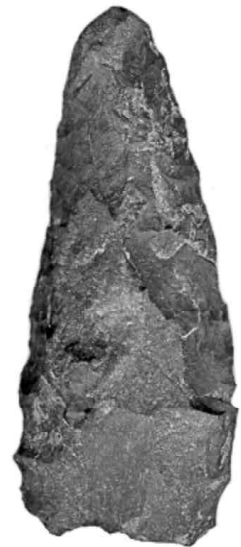

LR208

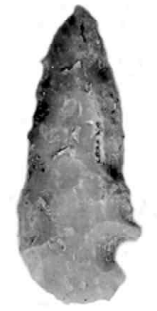

LR2 12a

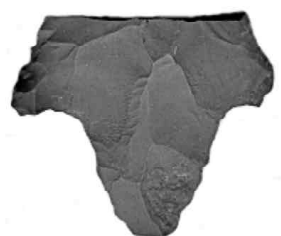

LR2 12b

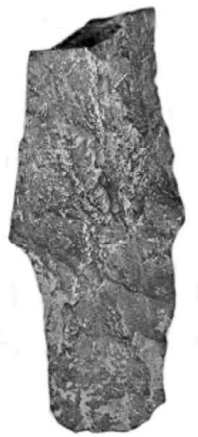

LR260a

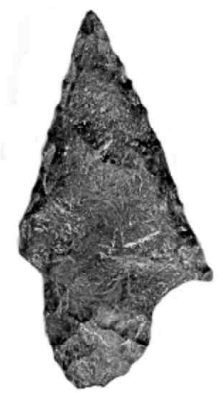

LR260b

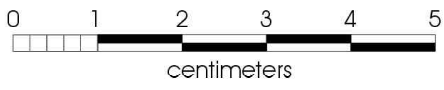

Figure 25. Representative bifaces recovered during the testing phase from various sites: (164a - untyped dart point; 164b - untyped dart point; 164c - untypeable dart point; 170 - Yarbrough dart point; 187 - untypeable dart point; 208 - biface blank; 212a - untypeable arrow point; 212b - Gary dart point; 260a - Wells dart point; 260b - Gary dart point) 


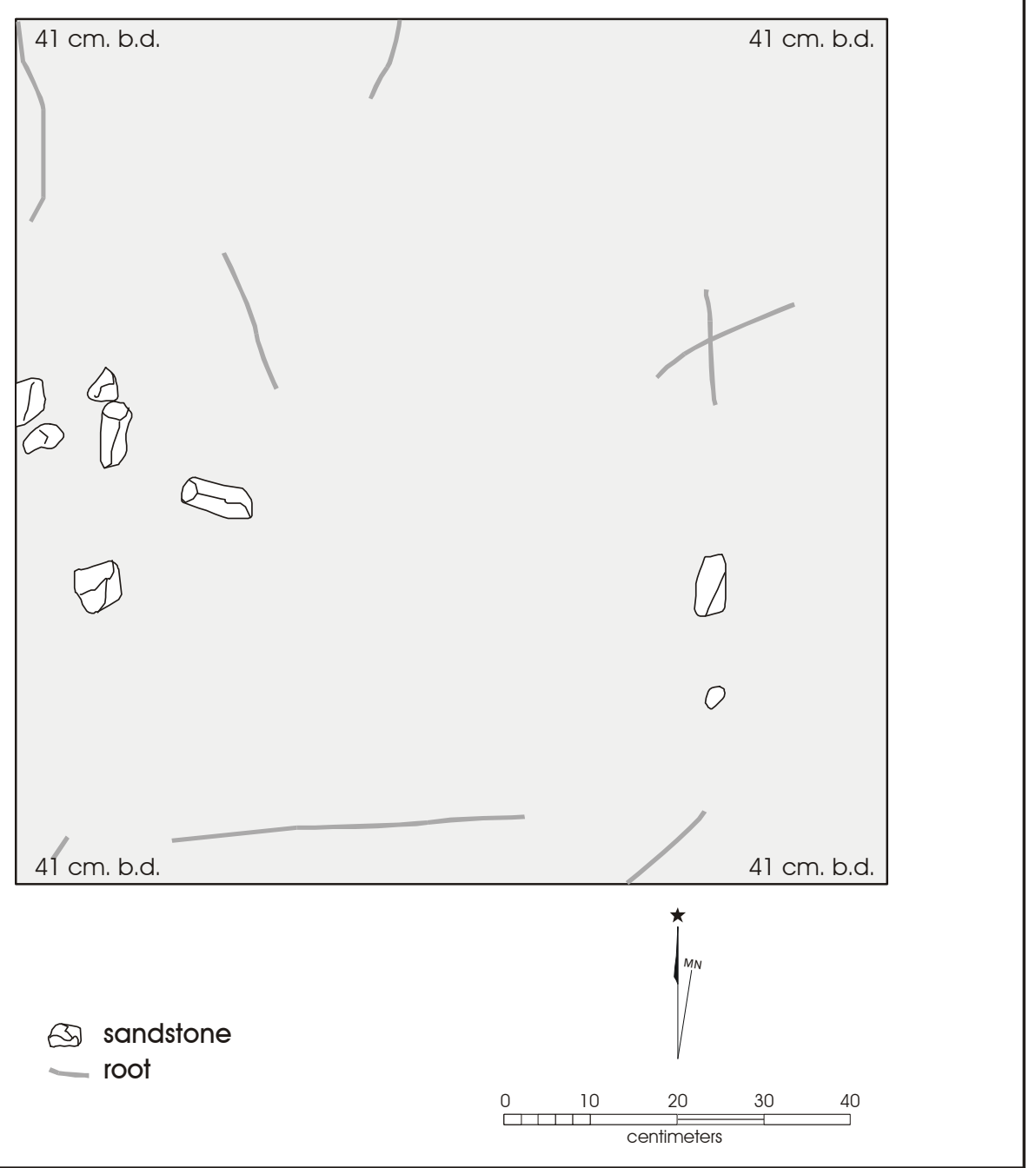

Figure 26. Plan view of 41LR164, Excavation Unit 1, Level 4, Feature 1.

\section{Radiocarbon}

Three burned sandstone samples from the feature were submitted to Beta Analytic, Inc., for radiometric dating of the organic remains within the interior surface (see Table 1). All three dates are similar, suggesting that the dating of organic remains within the interior of the burned sandstone may provide a reliable date for situations that lack charcoal (see Quigg 2000). An average of the radiocarbon age ranges (at 2 sigma) for these dates places the feature at approximately 2100 BP, within the pre-Caddoan Woodland period.

\section{Cultural Material}

\section{Native Ceramics}

A single plain grog-tempered body sherd $(7.0 \mathrm{~mm}$ thick) was recovered from Unit 6 at the far eastern end of the site. It is from a vessel that was fired in an oxidizing environment. The one sherd suggests that 41LR164 was used to a limited extent in either the Woodland or Late Prehistoric Caddoan periods. Ceramics were not found at the site during the archaeological survey investigations (Nickels et al. 1998). 


\section{Lithics}

\section{Tools}

A total of 11 stone tools were recovered from 41LR164. The assemblage includes three dart points, three biface fragments, two adzes, two cores, and one hammerstone. Two of the dart points are classified as untyped and the third as untypeable. The first untyped dart point (Figure 25, 164a) is parallel stemmed with a sub-rounded base, barbless, and alternate beveling of the blades. It is manufactured from medium-grained gray quartzite that does not appear to have been heattreated. The second untyped dart point (Figure 25, 164b) has a parallel to slightly contracting stem, straight base, barbless, strong shoulders, and slightly convex blades. It is manufactured from heat-treated, medium-grained gray quartzite. The untypeable dart point (Figure 25, 164c) has a long, narrow parallel stem, straight base, and is incomplete due to probable heat treatment of the green chert during late stage manufacture. The three biface fragments are untypeable, however they demonstrate the range of materials present at the site. Gray novaculite, white chert, and tan chert are each represented by one biface fragment. The untypeable and untyped dart points cannot offer a finer chronological resolution other than placing the site somewhere within the Archaic era.

The remainder of the stone tool assemblage lacks definite temporal affiliation, but the diversity of the assemblage suggests a range of activities occurring at the site. Two adzes, both manufactured from tan chert indicate part of a woodworking tool kit. Both adzes exhibit haft wear, and use wear on the bifacial adze (Cat. No. 78-2) is consistent with woodworking activities. The presence of two relatively small cores still possessing a majority of their former cortical surface is suggestive of expedient tool usage, although no expedient tools were recovered. Finally, a heavily utilized hammerstone was recovered from BHT 5 (see Figure 24). The hammerstone, a tan chert nodule, exhibits pecking along three faces.

\section{Debitage}

A total of 159 debitage was recovered during the 1998 survey and 2000 testing efforts at 41LR164. Of this total, 50 are chert, one is silicified wood, and 108 are quartzite. Among the assemblage, one chert flake and 12 quartzite flakes are heat-treated. This pattern suggests that, minimally, thermal alteration of stone raw materials to improve workability may have been of low importance at this site.

Chert and quartzite clearly dominate the debitage total. Of the 50 chert flakes, 27 are decorticate, 12 have $1-50 \%$ cortex, ten have $51-99 \%$ cortex, and one has $100 \%$ cortex. The mean thickness to length ratio for the chert debitage is 0.21 . Of the 108 quartzite flakes, 51 are decorticate, 35 have $1-50 \%$ cortex, 12 have $51-99 \%$ cortex, and ten have $100 \%$ cortex. The mean thickness to length ratio for the quartzite debitage is 0.22 . These patterns indicate that the primary lithic activity, as reflected by the recovered debitage, was middle stage reduction and tool manufacture.

An itemization of the flake types among the chert debitage presents one angular debris flake, one biface thinning flake, nine core preparation flakes, 25 platform preparation flakes, and 14 indeterminate flakes. Among the quartzite, there are three biface manufacture flakes, one biface rejuvenation flake, 44 core preparation flakes, 40 platform preparation flakes, and 20 indeterminate flakes. These comparisons further indicate tool manufacture as the primary activity represented in the lithic assemblage.

Debitage was encountered from $0-80 \mathrm{~cm}$ bs, with the greatest density (49\%) of flakes recovered within levels three and four, or $20-40 \mathrm{~cm}$ bs. Debitage density drops considerably below $60 \mathrm{~cm}$ bs, with only one flake recovered from $60-80 \mathrm{~cm}$ bs. Based upon the vertical distribution of this assemblage, a cultural zone is indicated from $20-40 \mathrm{~cm}$ bs.

Artifacts produced from non-local raw materials recovered from this site include novaculite, green cherts and gray cherts. Novaculite is generally associated with the Ouchita Mountains in Eastern Oklahoma and Western Arkansas. The green cherts are typically related to Oklahoma and may be encountered in Red River gravels. The gray cherts are typically associated with the Georgetown cherts of central Texas. 


\section{LR168}

\section{Description}

Site 41LR168 is located in the west-central portion of the facility along the right descending bankline of an unnamed tributary of Sanders Creek (see Figure 10 in supplement). The site is situated atop an upland landform of Whakana series fine sandy loams at $490 \mathrm{ft}$ AMSL. The vegetation community consists of the Quercus nigra-Ulmus americana Woodland and Schizachyrium scoparium Herbaceous classes, providing roughly $15 \%$ ground surface visibility.

Three excavation units, and 18 shovel tests were employed to define the site boundary (Figure 27). Based on these data, the site measures approximately $75 \mathrm{x}$ $60-\mathrm{m}$, and covers an area of roughly $3,360 \mathrm{~m}^{2}$. Within the current site boundary, six shovel tests were excavated, five (83\%) of which were positive. Cultural material extends from $0-80 \mathrm{~cm} \mathrm{bs}$, with the greatest density (39\%) of artifacts encountered $20-40 \mathrm{~cm}$ bs.

\section{Discussion}

Site 41LR168 was originally recorded as a moderately sized $\left(13,800 \mathrm{~m}^{2}\right)$ short-term open campsite during a June 1998 limited survey (Nickels et al 1998:69). In September 1999, CAR conducted a second survey, which included portions of the previously surveyed area. During this survey, additional positive shovel tests excavated to the south-southeast of 41LR168 were incorporated into the newly delimited site bounds, which then totaled 67,094 $\mathrm{m}^{2}$ (Lyle et al 2001:194). Recent additional shovel test excavations in concert with testing efforts conducted in September 2000 indicate that the 1999 delimited site bounds actually encompassed two separate sites. Specifically, the presence of an approximately $200 \mathrm{~m}$ corridor of negative shovel tests separating the two positive concentrations warrants separate site designations/trinomials. 41LR168 proper is delimited in the approximate area of its original designation (Figure 27).

Sediment susceptibility samples were collected from XU 1, at 10-cm intervals, from 0 to $40 \mathrm{~cm} \mathrm{bs}$. Examination of the values suggests that the 30-40 level has a significant increase in susceptibility, possibly indicating the presence of a buried surface. This corresponds to the bottom of the level at which the majority of artifacts were encountered.

\section{Cultural Material}

\section{Native Ceramics}

No ceramics were recovered during either phase of investigations.

\section{Lithics}

\section{Tools}

Three stone tools were recovered from 41LR168. The survey phase produced an untypeable dart point fragment (Cat. No. 132-1) recovered from the ground surface (Nickels et al. 1998:69). The dart point was manufactured from tan chert and is reminiscent of a Gary dart point. However, the complete lack of a stem precludes this determination of typology. Results of the testing phase produced another untypeable dart point fragment and an indeterminate biface. The dart point fragment is a probable point stem, with parallel lateral edges and a straight base. The indeterminate biface is manufactured from a heat-treated, finegrained gray quartzite. Analysis of these few specimens can only suggest a broad temporal affiliation with the Archaic era.

\section{Debitage}

A total of 14 debitage was recovered during the 1998 survey and 2000 testing efforts at 41LR168. Of this total, four are chert, two are novaculite, and eight are quartzite. Among the assemblage, one chert flake and one quartzite flake are heat-treated. This pattern suggests that, minimally, thermal alteration of stone raw materials to improve workability may have been of low importance at this site.

As at all of the sites in this study, chert and quartzite clearly dominate the debitage total. Of the four chert flakes, three are decorticate and one has $1-50 \%$ cortex. The mean thickness to length ratio for the chert debitage is 0.17 . Of the eight quartzite flakes, five are decorticate, one has $1-50 \%$ cortex, one has $51-99 \%$ cortex, and one has $100 \%$ cortex. The mean thickness to length ratio for the quartzite debitage is 0.16 . These 


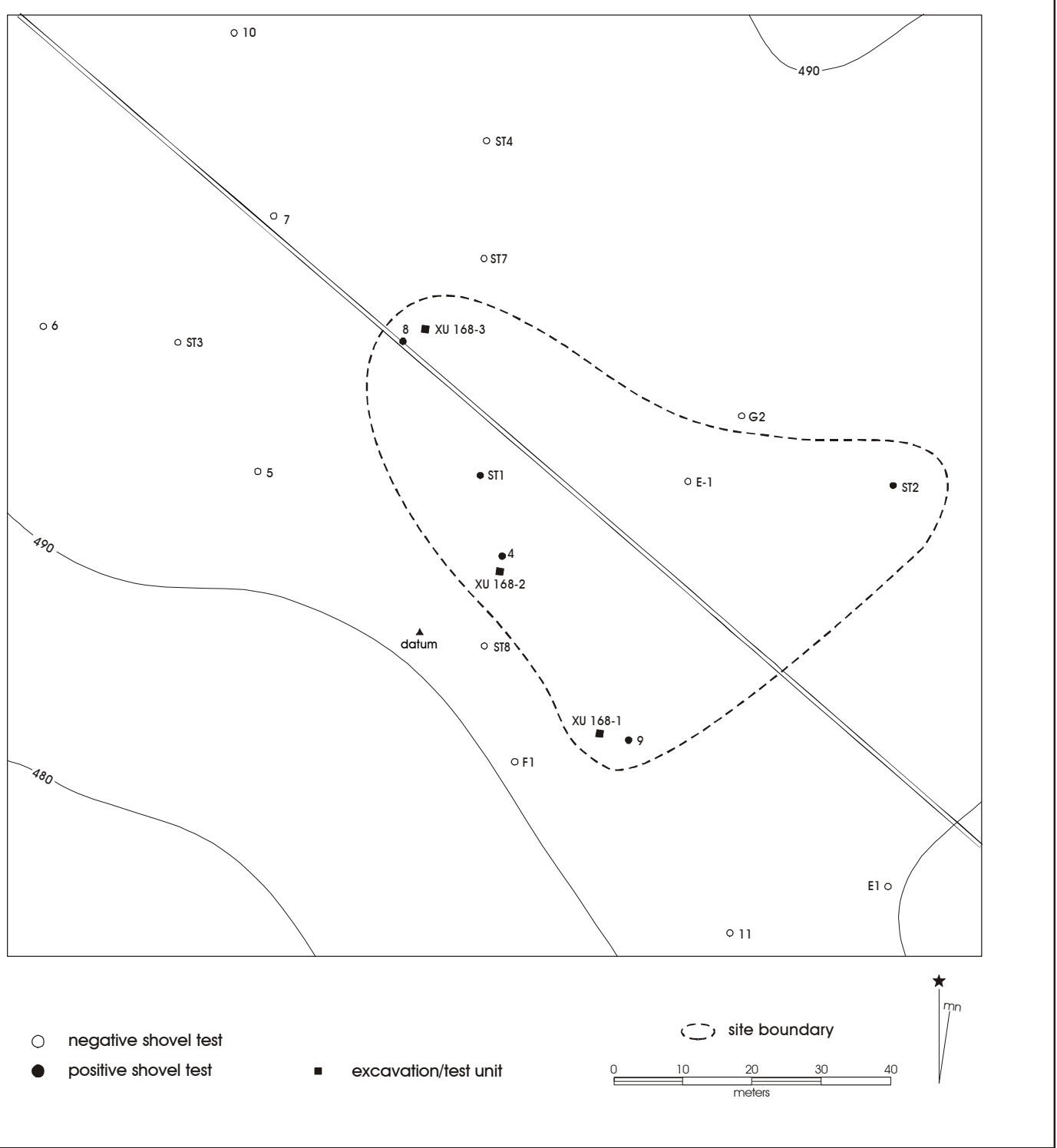

Figure 27. Site map - 41LR168.

patterns indicate that the primary lithic activity, as reflected by the recovered debitage, was middle stage reduction and tool manufacture.

An itemization of the flake types among the chert debitage presents four indeterminate flakes. Among the quartzite, there are three core preparation flakes and five indeterminate flakes. These comparisons further indicate tool manufacture as the primary activity represented in the lithic assemblage.

Debitage was encountered from $0-60 \mathrm{~cm}$ bs, with the greatest density $(50 \%)$ of flakes recovered within levels one and two, or 0-20 cm bs. Debitage density drops considerably below $40 \mathrm{~cm}$ bs, with only two flakes recovered from $40-60 \mathrm{~cm}$ bs. Based upon the vertical distribution of this assemblage, a cultural zone is indicated from $0-40 \mathrm{~cm}$ bs.

Artifacts produced from non-local raw materials recovered from this site include novaculite and gray cherts. Novaculite is generally associated with the Ouchita Mountains in Eastern Oklahoma and Western Arkansas. The gray cherts are typically associated with the Georgetown cherts of central Texas. 


\section{LR170}

\section{Description}

Site 41LR170 is located in the western portion of the facility approximately $80 \mathrm{~m}$ southeast of Pat Mayse Reservoir (see Figure 10 in supplement). The site is situated atop an upland finger ridge landform of Whakana series fine sandy loams at 490-500 ft AMSL. The vegetation community consists of the Quercus stellata-Quercus marilandica-(Carya texana) Woodland class, providing roughly $10 \%$ ground surface visibility.

Seven backhoe trenches, five excavation units, and 19 shovel tests were excavated in order to define the site boundary (Figure 28 [in supplement]). Based on these data, the site measures approximately $50 \times 260$ $\mathrm{m}$, and covers an area of about 10,980 square meters. Thirteen shovel tests were excavated within the current site boundary, ten $(77 \%)$ of which were positive. Cultural material extends from $0-130 \mathrm{~cm}$ bs, with the greatest density (24\%) of artifacts encountered within levels nine and ten, or $80-100 \mathrm{~cm}$ bs.

\section{Discussion}

Prior to test excavations, site 41LR170 appeared to be one of the richest and more promising sites identified by the survey. Survey shovel test results had produced one Dalton dart point, three arrow points, three bifaces, two edge-modified flakes, and numerous native ceramic sherds. However, once manual excavations were underway, it became readily apparent that substantial subsurface disturbance had occurred at the site. A subsequent review of the military-era activity maps reveals that at least five live grenade courts were in the general vicinity of the upland finger ridge. Indeed, hand grenade fragments were recovered throughout the vertical column, to depths of $70 \mathrm{~cm}$ bs. The depth of disturbance varies across the site from $70 \mathrm{~cm}$ bs to contact with the basal substrate (110-120 $\mathrm{cm} \mathrm{bs})$. In areas where the disturbance did not extend to the substrate an intact unit of light yellowish-brown fine sandy loam remains. This unit was only observed in the extreme northern portion of the site within the facility bounds. It is possible that this undisturbed unit extends north and west of the facility fence line, onto COE property; however, as a majority of the grenade courts are mapped in current COE lands, this possibility is very low.

A single prehistoric cultural feature (Feature 1) was identified in XU 3 at $70 \mathrm{~cm}$ bs. The burned rock feature is comprised of several burned quartzite cobbles and fragments, siliceous gravels, and ferruginous sandstone fragments clustered about a large (155 x 114-mm; $806 \mathrm{~g})$ slab of tabular, burned sandstone. The feature rests atop a unit of light yellowishbrown fine sandy loam and appears to be in situ. Likely associated with the cluster is a small deposit of charcoal and nutshell fragments.

Soil susceptibility samples were collected from XU 5, from 0 to $70 \mathrm{~cm}$ bs, at $10-\mathrm{cm}$ intervals. As detailed in Appendix B, no significant peaks were present in these values. The lack of significant increases associated with any single level suggests that, at least for the upper $70 \mathrm{~cm}$ of deposits, no buried surfaces are present.

\section{Cultural Material}

\section{Native Ceramics}

\section{Investigations (CAR)}

The one ceramic sherd from the CAR-UTSA work is a plain grog-tempered body sherd from ST 7 (0-20 $\mathrm{cm} \mathrm{bs})$. It is from a relatively thin-walled vessel (6.6 $\mathrm{mm}$ in thickness) that was fired in a reducing environment, but cooled in high oxygen conditions.

\section{Investigations (TXARNG)}

All 24 of the prehistoric ceramic sherds have been tempered with grog; two ( 8 percent) also have a sandy paste. Three sherds have decorations, another sherd is a plain rim, there are 16 plain body sherds, and four plain base sherds. The prevalence of grog-tempered ceramics at 41LR170 indicates that the occupation predates ca. A.D. 1300 , while the decorated sherds suggest the Caddoan occupation took place between ca. A.D. $900-1300$. 
One decorated rim sherd (ST 8, 40-60 cm bs) has a horizontal incised element on the rim; it is probably from a bowl (3.6 $\mathrm{mm}$ wall thickness). The rim is direct or vertical, with a flat lip. The second decorated rim (ST 12, 40-60 cm bs) appears to be from a carinated bowl that has at least four diagonal engraved lines; the rim (5.4 mm in thickness) is direct with a rounded lip. Similar decorated sherds have been found in Early and Middle Caddoan contexts in the middle reaches of the Red River and Sulphur River basins in Northeast Texas (see Perttula 1997). This sherd also has a sandy paste. The third decorated sherd (ST 17, $20-40 \mathrm{~cm}$ bs) has diagonally opposed incised lines. It is tempered with grog, and has thick body walls $(9.2 \mathrm{~mm})$. The plain rim is from ST $10(0-20 \mathrm{~cm} \mathrm{bs})$. It is direct with a flat lip, and has thin walls $(4.4 \mathrm{~mm})$. The plain body sherds average $7.98 \mathrm{~mm}$ in thickness $(\mathrm{sd}=2.14 \mathrm{~mm})$. Several plain grog-tempered sherds are more than $9.2 \mathrm{~mm}$ in thickness, however, including one sherd from ST 10 (20-40 cm bs), one sherd from ST 12 (20-40 mm bs), and two sherds from ST 7 (60$70 \mathrm{~cm} \mathrm{bs})$. These may be from Williams Plain bowls and jars, which were manufactured and used between ca. A.D. 700-1300 in this part of the Caddoan area. The grog-tempered base sherds are also thick (12.9 \pm $0.1 \mathrm{~mm}$ ); the grog-tempered sandy paste base sherd is only $7.7 \mathrm{~mm}$ in thickness.

In the TXARNG shovel test investigations, the artifact density was slightly higher at 5.90 artifacts per positive shovel test, but again the prehistoric materials were concentrated in the northwestern corner of the TXARNG property, although also extending approximately $20 \mathrm{~m}$ west onto the COE, Tulsa District property at Pat Mayse Lake. The TXARNG investigations recovered a much higher density of ceramics (1.9 per positive shovel test and in 60 percent of the positive shovel tests compared to 0.1 per positive shovel test and 10 percent of the positive shovel tests in the CAR-UTSA work), and the ceramics were common to at least approximately $80 \mathrm{~cm}$ bs. The TXARNG work also recovered daub $(n=3)$ in two shovel tests between $20-60 \mathrm{~cm}$ bs, suggesting the presence of a Caddoan structure.

\section{Investigations}

There are 52 sherds, as well as a single piece of daub, recovered in the test excavations at 41LR170 (Table 2). Most of these are from Units 1 and 4, excavated next to BHT 2, in the west-central part of the site. This is the same area with the highest concentrations of sherds and other artifacts noted in the earlier archaeological survey investigations completed by the TXARNG (Lyle et al. 2001:Figure C-32).

Eight sherds, two rims and six body sherds are decorated; the plain/decorated sherd ratio is 4.50 . The decorated sherds include three with incising, three with punctations, and two with engraving. The incised sherds (BHT 2, XU 1, 30-40 cm bs, and XU 4, 70-80 $\mathrm{cm}$ bs) have closely-spaced sets of parallel, probably horizontal, lines. One such horizontal incised sherd was previously recovered during the archaeological survey investigations at 41LR170 (Lyle et al. 2001). One of the punctated sherds (XU 5, 20-30 cm bs) has at least two rows of cane punctations, while the other two sherds have fingernail punctations. The first (XU 1, 40-50 cm bs), a rim (direct, with a rounded lip), has diagonal and vertical fingernail punctated elements, while the second (BHT 3) has at least one row of fingernail punctations on a body sherd.

There are three plain rims, one from XU $1(40-50 \mathrm{~cm}$ bs) and two from BHT 3. All three rims are direct in profile, the former (grog-hematite tempered) has a flat lip, and the two grog-tempered rims from BHT 3 have rounded lips. All three are from separate vesselsone probably a jar based on evidence of interior surface smoothing - that have been fired in a reducing environment and subsequently cooled in the open air. The rims are $6.6 \pm 1.0 \mathrm{~mm}$ in thickness.

There are a total of 41 plain body sherds, of these 15 are too small for meaningful analysis. The remaining plain body sherds include those that have been grogtempered $(n=17)$, grog-hematite-tempered $(n=5)$, grogbone-tempered $(n=3)$, and bone-tempered $(n=1)$. All are relatively thick-walled compared to the other Camp Maxey ceramic assemblages, as is also apparent from the sherds found during the archaeological survey (Lyle et al. 2001:230). Body wall thickness ranges from $6.73 \pm 0.89 \mathrm{~mm}$ for the grog-bone-tempered sherds to $7.76 \pm 0.99 \mathrm{~mm}$ for the sandy paste grogtempered vessels. The mean sherd thickness for the plain body sherds recovered during the 
Table 2. Inventory of native ceramics recovered during testing

\begin{tabular}{|c|c|c|c|c|c|c|c|}
\hline Site & $\begin{array}{c}\text { Undecorated } \\
\text { Sherds }\end{array}$ & Vessel & Sherdlets & $\begin{array}{l}\text { Decorated } \\
\text { Sherds }\end{array}$ & Daub & Fired Clav & Pipe Sherd \\
\hline 41LR152 & 21 & 1 & 6 & 3 & & & \\
\hline 41LR157 & 13 & & 2 & 2 & & & \\
\hline 41LR163 & & & 1 & & & & \\
\hline 41LR164 & 1 & & & & & & \\
\hline 41LR170 & 26 & & 15 & 11 & 1 & & \\
\hline 41LR186 & 31 & & & 8 & & 1 & \\
\hline 41LR187 & 252 & & 21 & 41 & & 4 & 1 \\
\hline 41LR202 & 1 & & & & & & \\
\hline 41LR204 & 7 & & & & & & \\
\hline 41LR212 & 2 & & & & & & \\
\hline 41LR260 & 32 & & 4 & 1 & & 1 & \\
\hline Total & 386 & 1 & 49 & 66 & 1 & 6 & 1 \\
\hline
\end{tabular}

archaeological survey is $7.98 \pm 2.14 \mathrm{~mm}$. Several of these are probably from Williams Plain vessels.

Most of the plain and decorated grog-tempered sherds (62 percent) at 41LR170 are from vessels fired in a reducing or low oxygen environment. The one bonetempered vessel sherd has also been fired in this manner. By contrast, the grog-hematite-tempered ( 86 percent), grog-tempered and sandy paste (83 percent), and grog-bone-tempered (67 percent) vessel sherds come from vessels either fired in an oxidizing environment or incompletely oxidized during firing. For the site as a whole, 45 percent of the sherds are from vessels fired in a reducing environment.

The three base sherds (BHT 3, XU 1, 20-30 cm bs, and XU 4, 60-70 cm bs) are each from separate vessels. Two are tempered with grog, and the third is tempered with grog, but has a sandy paste. Two of the three base sherds are from vessels either oxidized or incompletely oxidized during firing. Mean thickness of the base sherds is $10.9 \pm 0.93 \mathrm{~mm}$.

The one piece of daub (2.2 g) is from XU 4 $(20-30 \mathrm{~cm} \mathrm{bs})$. The daub is blackened, and is probably a remnant of a plastered wall from a burned Caddoan structure.

The frequency of horizontal and parallel incised decorated sherds, as well as fingernail punctated sherds, and the simple horizontal and curvilinear engraved decorations, all suggest that the principal Caddoan component at 41LR170 dates to the Early Caddoan period. Also notable at the site is the absence of redslipped sherds, a particular feature of Middle Caddoan period ceramic assemblages along the middle Red River basin, and the generally thick grog-tempered wares (some possibly Williams Plain) here.

\section{Lithics}

Tools

Twenty-eight stone tools were recovered from 41LR170. This assemblage includes four dart points, four arrow points, one arrow point preform, five bifaces, four edge-modified flakes, nine cores, and one hammerstone. Of the dart points, one is heavily reworked Dalton with evidence of heat-treatment and fluvial transport. The Dalton exhibits typical reworking of the blades and may have later functioned as a drill. The tip of the Dalton is broken with a probable use break step fracture. The Dalton is manufactured from tan chert. The second dart point is a complete Yarbrough (Figure 25, 170) recovered from an unprovenienced location within BHT 1 (see Figure 28). The Yarbrough has a parallel stem with a straight base. It is barbless, with weak shoulders, appears reworked along one of the blades, and has a break at the extreme distal portion of the tip. It is manufactured from a green and tan banded chert. The third and fourth dart points are fragments. One is a distal fragment of tan chert (ST 10-1) while the other (ST 4) is a medial fragment of gray novaculite. These two fragments were recovered during TXARNG excavations. 
Both of the complete arrow points are untyped. The first arrow point (Cat. No. 13-2), recovered during TXARNG exploration of the site, resembles an Albatype with its parallel to slightly expanding stem, subrounded base and absence of barbs. It is manufactured from a dark gray chert that may have been heat-treated. The second complete arrow point (Cat. No. 283-1) is made of local yellow chert. The small specimen is completely unifacially flaked with short non-intrusive retouch flakes. It has a slightly expanding stem and convex base. The two arrow point fragments are untypeable due to incompleteness. The first arrow point fragment (Cat. No. 134) is a small, cornernotched variety that seems to have suffered a manufacture break during late stage reduction. It is manufactured from tan chert and exhibits approximately $40 \%$ cortex along the stem. The second arrow point fragment (Cat. No. 279) is a medial fragment with fine lateral serrations. The point is manufactured from a fine-grained white quartzite. The final arrow point (Cat. No. 283-2) is made on a short yet thick flake blank. Given the rough form, it appears to represent a manufacture failed preform or blank, rather than a finished specimen.

The five bifaces consist of three distal $(n=3)$ and two complete specimens. Of the two, one is petrified wood while the other is a fined-grained gray chert. Among the edge-modified flakes, three are expedient scrapers with evident use wear. The fourth edge-modified flake (Cat. No. 301-3) is a probable unifacial graver manufactured from gray quartzite. Of the nine cores recovered, seven are medium to coarse-grained quartzite. The remaining two cores are chert, with two exhausted cores, one (Cat. No. 299-2) of white chert and the other a siliceous pebble (Cat. No. 315-4) of tan chert. One of the cores (Cat. No. 135) is a bipolar specimen. The final artifact is a quartzite hammerstone (Cat. No. 335-2). It measures 71 × 56 × $32 \mathrm{~mm}$ in maximum length, width and thickness.

The assemblage of lithic materials present here spans the Paleoindian through Late Prehistoric Caddoan periods. Based upon the stratigraphic position of the recovered materials alone, the depositional integrity of the site is suspect. Combined with the knowledge of the amount of disturbance exhibited at this site from early historic land use and subsequent military bombardment, it is unfortunate to determine most, if not all, of the material recovered is out of context.

\section{Debitage}

A total of 237 debitage was recovered during the 19992000 survey and 2000 testing efforts at 41LR170. Of these items, 55 are from Maxey II and the remaining 182 are from Maxey III. Of this total, 107 are chert, four are novaculite, two are silicified wood, and 124 are quartzite. Among the assemblage, one chert flake and six quartzite flakes are heat-treated. This pattern suggests that, minimally, thermal alteration of stone raw materials to improve workability may have been of low importance at this site.

As at all of the sites in this study, chert and quartzite clearly dominate the debitage total. Of the 107 chert flakes, 52 are decorticate, 26 have $1-50 \%$ cortex, 26 have $51-99 \%$ cortex, and three have $100 \%$ cortex. The mean thickness to length ratio for the chert debitage is 0.19 . Of the 124 quartzite flakes, 67 are decorticate, 31 have $1-50 \%$ cortex, 19 have $51-99 \%$ cortex, and seven have $100 \%$ cortex. The mean thickness to length ratio for the quartzite debitage is 0.19 . These patterns indicate that the primary lithic activity, as reflected by the recovered debitage, was middle stage reduction and tool manufacture.

An itemization of the flake types among the chert debitage presents four angular debris flakes, two biface manufacture flakes, one biface rejuvenation flake, three biface thinning flakes, 35 core preparation flakes, 22 platform preparation flakes, and 40 indeterminate flakes. Among the quartzite, there are three biface manufacture flakes, one biface thinning flake, 32 core preparation flakes, 43 platform preparation flakes, and 45 indeterminate flakes. These comparisons further indicate tool manufacture as the primary activity represented in the lithic assemblage.

Debitage was encountered from $0-120 \mathrm{~cm}$ bs, with the greatest density (23\%) of flakes recovered within levels three and four, or 20-40 cm bs. Debitage density drops below $100 \mathrm{~cm}$ bs, with only eight flakes recovered from 100-120 cm bs. Based upon the vertical distribution of this assemblage, no definable stratification of discrete cultural deposits is evident. 
Artifacts produced from non-local raw materials recovered from this site include novaculite, green cherts and gray cherts. Novaculite is generally associated with the Ouchita Mountains in Eastern Oklahoma and Western Arkansas. The green cherts are typically related to Oklahoma and may be encountered in Red River gravels. The gray cherts are typically associated with the Georgetown cherts of central Texas.

\section{LR186}

\section{Description}

Site 41LR186 is located in the northwestern portion of the facility approximately $100 \mathrm{~m}$ south and east of Pat Mayse Reservoir (see Figure 10 in supplement). The site is situated atop an upland ridge landform of Woodtell series loams at 490-500 ft AMSL. The vegetation community consists of the Quercus stellataQuercus marilandica-(Carya texana) Woodland class, providing roughly $10 \%$ ground surface visibility.

Eight backhoe trenches, six excavation/test units, and 137 shovel tests were used to define the site boundary (Figure 29 [in supplement]). Four of the backhoe trenches located along the southeastern portion of the site (BHTs 4[SE]-7) were excavated in 1999. Four additional trenches (BHTs 1-4[SW]), located in the central and southwestern portion of the site, were excavated in 2000. Similarly, two of the excavation/test units (A-6 and TU 3) were dug in 1999. Based on these data, the site measures approximately $200 \times 450$ $\mathrm{m}$, and covers an area of $38,120 \mathrm{~m}^{2}$. In the current site boundary, 131 shovel tests were excavated. Fifty-four $(41 \%)$ of the 131 on-site shovel tests were positive. Cultural material extends from $0-100 \mathrm{~cm} \mathrm{bs}$, with the greatest density (35\%) of provenienced artifacts encountered in levels five and six, or $40-60 \mathrm{~cm}$ bs.

\section{Discussion}

This site is interesting in that it spans the entirety of a long meandering upland ridge adjacent to the current Pat Mayse Reservoir. The site extends for approximately $450 \mathrm{~m}$ within the facility and probably continues northward onto COE property, at which point the finger ridge terminates. At least three relatively dense concentrations of cultural material were identified during the survey and testing phases.

To facilitate discussion of this large site, it will be discussed in three sections (see Figure 29 [in supplement]):

$$
\begin{aligned}
& \text { "A" - Northern section; } \\
& \text { "B" - Central section; and } \\
& \text { "C" - Southern section. }
\end{aligned}
$$

Section "A" contains the northern portion of the site, which probably extends onto COE property. This large section contained scattered concentrations of lithic debitage and burned rocks and a sparse surface scatter of historic debris. Through the excavation of 57 shovel tests, no native ceramics were recovered from this section; however, without the recovery of diagnostic lithics, this section cannot be separated temporally from the remainder of the site. Three separate concentrations of positive shovel tests occur within section "A." The eastern and southern concentrations are situated along the ravine that forms the eastern boundary of the site. The northern concentration exists atop a finger ridge, with the northern terminus at Pat Mayse Reservoir on COE property. Due to the sparse, dispersed nature of this section of the site, no backhoe trenches or other units were excavated.

Section "B" consists of a dense concentration of native ceramics, lithic debitage, and burned rock and was the primary focus of the test investigations at this site. This section is bound generally to the north and east by an associated ravine, to the south by an upland drainage leading to a southern ravine, and to the west by numerous negative shovel tests. During the survey phase, over $71 \%$ of the native ceramic assemblage of 41LR186 was recovered from this approximately 50 $\mathrm{m}^{2}$ area. Accordingly, two backhoe trenches, each with an associated $1 \mathrm{~m}^{2}$ excavation unit, were situated adjacent shovel tests that produced a high yield of cultural material during the survey phase, located within the central portion of the concentration.

A single feature (Figure 30) was recorded at 60-70 $\mathrm{cm}$ bs within XU 2 adjacent BHT 2. It was estimated that one-half of the feature was removed during excavation of the backhoe trench. This, in turn, dictated 


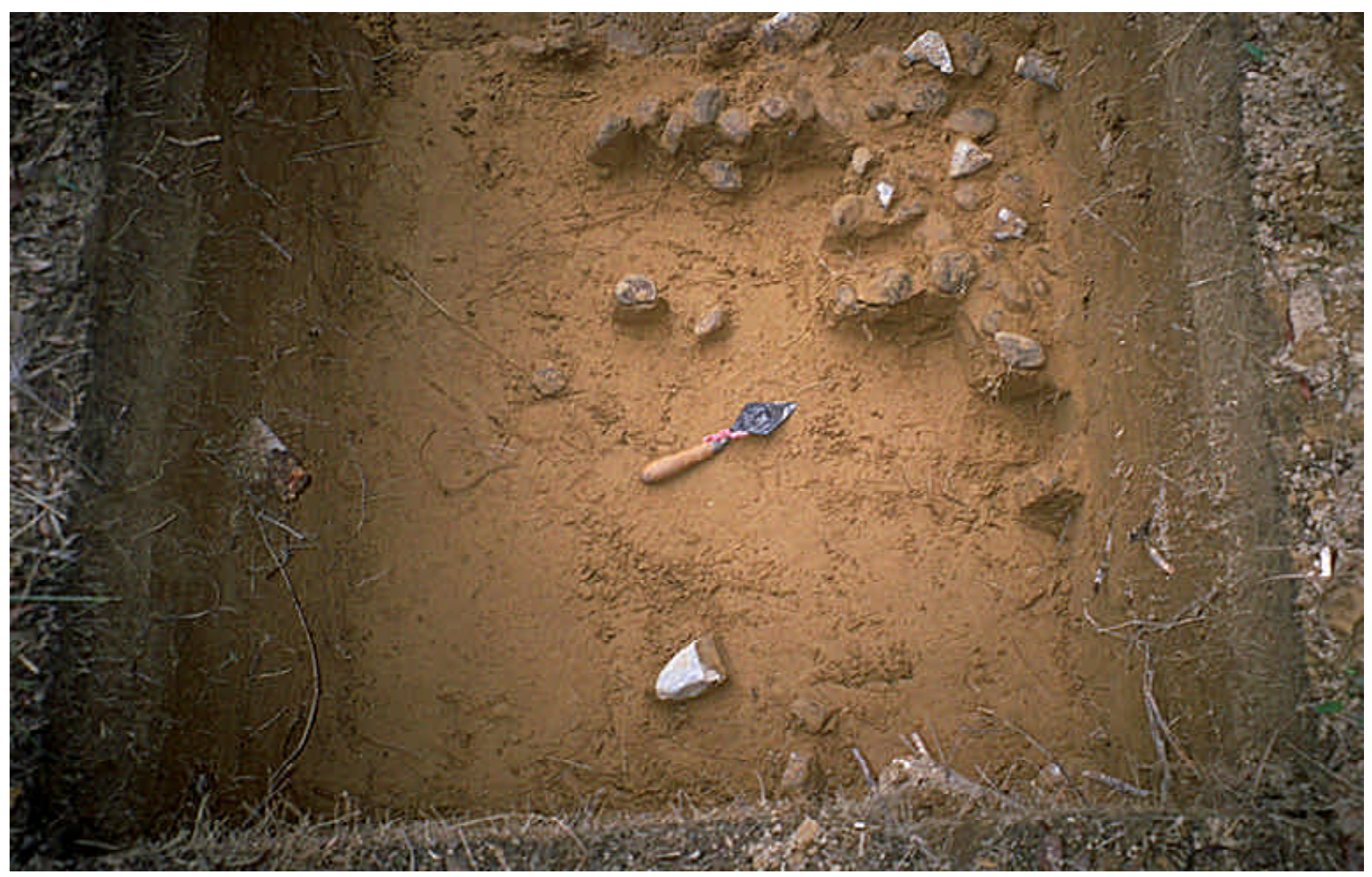

Figure 30. Plan view of 41LR186, XU 1, Level 7, Feature 1.

the placement of the excavation unit with hopes of adequate data recovery of the remainder of the feature. Excavation revealed the remnant of what appears to be a burned rock cluster, or thermal feature. The original dimensions were probably in the order of $1-\mathrm{m}$ in diameter, with a maximum vertical thickness of $10-15-\mathrm{cm}$. Artifacts recovered in association with the feature include several lithic flakes within the matrix and a single proximal end of a biface located immediately beneath the feature. No charcoal, bone, organic staining or other evidence of a food-processing feature was apparent.

Section "C" is comprised of a sparse scatter of lithic debitage, burned rock, and native ceramics along the southern portion of the site. The cluster of shovel tests, located along the ravine forming the southwestern portion of the landform, produced roughly $29 \%$ of the recovered ceramics during the survey investigations at this site. For that reason, a single backhoe trench and two excavation units were placed within the density of shovel tests. Section "C" also contained five additional backhoe trenches (BHTs 4[SW] and 4[SE] -7) excavated during 1999.

The results of the testing phase do not corroborate the previous survey investigation. Specifically, the densities of native ceramics recovered from the four excavation units are considerably lower than the results of the survey phase shovel tests. One explanation of this discrepancy would be variation in site structure and the fortuitous placement of units relative to particular areas of discard within varied use areas of the site. Extensive subsurface disturbance, although not encountered in the excavation units, is equally possible.

Sediment susceptibility samples were collected from XU 2, from 0 to $100 \mathrm{~cm}$ bs, at $10-\mathrm{cm}$ intervals. As detailed in Appendix B, no significant peaks were noted in the values with the possible exception of a slight increase at 40 to $50 \mathrm{~cm}$ bs. This lack of any significant spike suggests that, at least in the single area tested, no buried surfaces are present. 


\section{Cultural Material}

\section{Native Ceramics}

\section{Investigations}

Including the artifacts from the surface, there are 39 ceramic sherds and one piece of burned clay (ST 85, $60-80 \mathrm{~cm} \mathrm{bs})$ in the assemblage. The ceramic sherds are most abundant in ST $32(\mathrm{n}=5)$, ST $33(\mathrm{n}=5)$, and ST $89(n=4)$, all from the central part of the landform. The density of ceramics in the many positive shovel tests is 0.82 , and 4.0 per square meter in the one $50 \mathrm{x}$ $50-\mathrm{cm}$ unit in the central site area.

The 39 sherds include 30 plain body sherds, a plain rim, three engraved, two incised, one pinched, one incised-punctated, and one punctated sherd. The plain/ decorated sherd ratio is 3.88 . About $87 \%$ of the sherds have been tempered with grog (or crushed sherds), $5 \%$ have grit temper, and $8 \%$ have bone temper. Among the grog-tempered sherds, several also have additional temper inclusions, including bone $(n=6)$ and hematite $(n=1)$. One other sherd, with grog-bone temper, also has a sandy paste. The proportion of ceramic sherds with some amount of crushed and burned bone temper is $23 \%$.

The sherds are from coiled and well-made vessels, with a mean body wall thickness of $6.5 \mathrm{~mm}$ (range $3.3-10.2 \mathrm{~mm})$. About $20 \%$ of the sherds are relatively thick ( $>8.7 \mathrm{~mm}$ in body wall thickness), and include six plain body sherds (probably Williams Plain, see Schambach 1998), one pinched body sherd, and a fingernail punctated body sherd (both of these are from vessels that were incompletely oxidized during firing); many of these are from the surface around ST 32 on the central part of the landform and are tempered with grog or grog-bone. The majority of the sherds are from vessels that have been fired in a reducing environment (67\%), with most of these then having been cooled in a high oxygen environment (see Teltser 1993). The thinner decorated sherds are all from vessels fired in a reducing environment.

Among the few decorated sherds, the engraved wares $(\mathrm{n}=3)$ are most common. One (ST 85, 40-60 cm bs) has only a single engraved line, while the two from ST 32 have diagonal engraved lines $(40-60 \mathrm{~cm}$ bs, from a carinated bowl) and multiple curvilinear engraved lines (20-40 cm bs), respectively; both of these sherds have bone temper, with the former also having grog as a tempering inclusion. The two incised sherds (both from ST 32, 40-60 cm bs) have parallel and vertical decorative elements, and both are tempered with grog. There is a curvilinear and horizontal incised and zoned punctated sherd (probably Crockett Curvilinear Incised) from ST $19(60-80 \mathrm{~cm} \mathrm{bs})$ on the southern part of the landform, and it is tempered with grog. Another grog-tempered sherd (ST 92, 40-51 cm bs) from the southern part of the landform has a thick $(8.9 \mathrm{~mm})$ pinched body, and there is a thick $(10.2 \mathrm{~mm})$ fingernail punctated body sherd (grog-tempered) from the surface around ST 19. Overall, the few decorated sherds are consistent with a pre-A.D. 1300 Caddoan component, and the combination of bone tempering, along with several thicker grog-tempered sherds with decoration, suggests the Caddoan occupation may have occurred in the ca. A.D. 900-1100 interval.

The one plain rim (ST 33, 40-60 cm bs) has a direct rim and a rounded lip and has been tempered with grog. It is $4.6 \mathrm{~mm}$ thick.

\section{Investigations}

Eight sherds, one of which was less than $1 \mathrm{~cm}$ in length, were recovered from BHT 1, BHT 3, and XU 1. A single body sherd recovered from BHT 1 is decorated. It is from a grog-tempered bowl (7.1 mm thick), and has at least three regularly spaced curvilinear incised lines. A similar curvilinear sherd was recovered during the archaeological survey, and it was identified as a probable Crockett Curvilinear Incised type (Lyle et al. 2001:203). The limited evidence from the decorated sherds in the survey and test excavations suggests an Early Caddoan period occupation.

One of the remaining sherds (XU 1, 0-10 cm) is a plain grog-tempered rim with a rounded lip. The other sherds are plain body sherds, all tempered with grog; one of these also has a sandy paste, and another has crushed hematite in the paste. Sherd thicknesses range from $5.0 \mathrm{~mm}$ (rim) to $9.0 \mathrm{~mm}$ (body sherd). The mean thickness of the grog-tempered sherds is $6.92 \pm 0.90$ $\mathrm{mm}$. The sherds are equally divided in deriving from vessels fired either in a reducing environment or an incompletely oxidized environment. In the larger sherd sample obtained in the archaeological survey, 67 percent of the sherds were from vessels that had been fired in a reducing environment (Lyle et al. 2001:202). 


\section{Lithics}

\section{Tools}

Seventeen stone tools were recovered from 41LR186. The collection consists of a Gary dart point preform, an arrow point fragment, a drill, four biface fragments, an adze, three hammerstones, three edge-modified flakes, and three cores. The Gary dart point preform is a manufacture failure of very coarse-grained green quartzite. The proximal arrow point fragment is parallel stemmed with a rounded base. It is manufactured from heat-treated, medium-grained gray quartzite. These two artifacts are the only potentially temporal diagnostics from the lithic assemblage, indicating either a multiple component Archaic and Late Prehistoric site, or potentially a single component Woodland period occupation.

The drill (Cat. No. 198) is manufactured of white chert. One of the four biface fragments is an early stage reduction manufacture failure. It is manufactured from heat-treated red/pink quartzite. A second biface fragment (Cat. No. 242-3) is also a manufacture-failed specimen. It is made of black chert. The other two biface fragments are manufactured from chert and are manufacture failure fragments. Both appear to be lateral, or blade edges.

The remainder of the lithic tool assemblage suggests a more diverse range of activities compared with most sites in the project area. A bifacial adze (Cat. No. 254-1) exhibits haft wear consistent with unsheathed wood or bone. The use wear along the working edge is indicative of chopping a hard substance, probably wood. Of interest, the adze is manufactured from silicified wood. The hammerstone is of indeterminate raw material type and exhibits moderate pecking along one face. Two additional hammerstone fragments of quartzite were recovered during the 1999 field season. The three edge-modified flakes are all expedient scrapers that have use wear consistent with scraping activities. Two of the three cores are fine-grained chert, both are multi-directional. The third core is a bipolar silicified wood split cobble.

\section{Debitage}

A total of 240 debitage was recovered during the 19992000 survey and 2000 testing efforts at 41LR186. Of these items, 111 were recovered during the 2000 testing effort while 129 are from the 1999-2000 survey. Of this total, 124 are chert, four are novaculite, three are silicified wood, 103 are quartzite, two are quartz, and four are silicified sandstone. Among the assemblage, seven chert flakes and three quartzite flakes are heat-treated. This pattern suggests that, minimally, thermal alteration of stone raw materials to improve workability may have been of low importance at this site.

As at all of the sites in this study, chert and quartzite clearly dominate the debitage total. Of the 124 chert flakes, 80 are decorticate, 27 have $1-50 \%$ cortex, 15 have $51-99 \%$ cortex, and two have $100 \%$ cortex. The mean thickness to length ratio for the chert debitage is 0.19 . Of the 103 quartzite flakes, 48 are decorticate, 27 have $1-50 \%$ cortex, 15 have $51-99 \%$ cortex, and 13 have $100 \%$ cortex. The mean thickness to length ratio for the quartzite debitage is 0.20 . These patterns indicate that the primary lithic activity at this site, as reflected by the recovered debitage, was early to middle stage reduction and tool manufacture/ rejuvenation.

An itemization of the flake types among the chert debitage presents five angular debris flakes, four biface manufacture flakes, one biface resharpening flake, five biface thinning flakes, one blade, 14 core preparation flakes, 36 platform preparation flakes, and 58 indeterminate flakes. Among the quartzite, there are three biface manufacture flakes, two biface thinning flakes, 33 core preparation flakes, 23 platform preparation flakes, and 42 indeterminate flakes. These comparisons further indicate tool manufacture as the primary activity represented in the lithic assemblage.

Debitage was encountered from $0-120 \mathrm{~cm}$ bs, with the greatest density (32\%) of flakes recovered within levels five and six, or 40-60 cm bs. Debitage density drops considerably below $100 \mathrm{~cm}$ bs, with only one flake recovered from 100-120 cm bs. Based upon the vertical distribution of this assemblage, a cultural zone is indicated from $40-60 \mathrm{~cm}$ bs. 
Artifacts produced from non-local raw materials recovered from this site include novaculite, quartz, and gray cherts. Novaculite is generally associated with the Ouchita Mountains in Eastern Oklahoma and Western Arkansas. Similarly, quartz is indicative of an Ouchita Mountain source and may be encountered along the Red River. Gray cherts are typically associated with the Georgetown cherts of central Texas.

\section{LR187}

\section{Description}

Site 41LR187 is located in the northwestern portion of the facility approximately $100 \mathrm{~m}$ south of Pat Mayse Reservoir (see Figure 10 in supplement). The site is situated atop an upland ridge landform of Whakana series fine sandy loams at 490-500 ft AMSL. The vegetation community consists of the Quercus stellataQuercus marilandica-(Carya texana) Woodland class, providing roughly $15 \%$ ground surface visibility.

Five backhoe trenches, four excavation units, and 40 shovel tests were excavated to define site boundaries (Figure 31). Based on these data, the site measures approximately 110 x 240-m and covers about 14,590 square meters. A total of 37 shovel tests were excavated on site, with 28 (76\%) of these being positive. Cultural material extends from $0-100 \mathrm{~cm} \mathrm{bs}$, with the greatest density (39\%) of provenienced artifacts encountered within levels three and four, or $20-40 \mathrm{~cm}$ bs.

\section{Discussion}

The site consists of three distinct areal concentrations of deposits (Figure 31). To facilitate discussion of the different areas of the site, they are here identified as:

"Area A" — Northern section;

"Area B" - Central section; and

"Area C" - Southern section.

Judging by the current topographic relief across the site, it is likely that upland drainages were either present at the time of prehistoric occupation or have since dissected the site into the current divisions. In any event, Areas "A" and "B" exhibit very rich cultural deposits from $20-60 \mathrm{~cm}$ bs. While a discernible paleosol was not encountered, the artifact density drops sharply below $60 \mathrm{~cm}$ bs, containing less than seven percent of the total assemblage. The southern section of the site, however, does not exhibit similar deposits. Excavation of XU 3 (Figure 31) recovered only seven ceramic sherds and, in total, accounted for less than $4 \%$ of the overall artifact assemblage. Sitedelimiting shovel tests excavated in Area " $\mathrm{C}$ " during the testing phase corroborate this assertion.

\section{Radiocarbon}

Two charcoal samples recovered from apparently good stratigraphic context in Areas " $A$ " and "B" were submitted to Beta Analytic, Inc., for radiometric dating (see Table 1). The first sample (Beta No. 153594; Cat. No. 332-1) returned a date of modern, or historic age (302-0 вр). This late date is rejected due to its inconsistency with the diagnostic artifacts recovered ranging from the Late Archaic to Middle Caddoan periods. The second sample submitted (Beta No. 153595; Cat. No. 333-1) returned a date of 4090-3866 вр. While this date would be consistent with the recovered Gary dart point, it would predate native ceramics in northeast Texas by over 1,000 years. As this second sample was recovered in good stratigraphic context with abundant ceramics, this date, too, is rejected.

Sediment susceptibility samples were collected from XU 1, from 0 to $80 \mathrm{~cm}$ bs, at $10-\mathrm{cm}$ intervals. As detailed in Appendix B, two possible surfaces are indicated by the values. The first is at 50 to 60 $\mathrm{cm}$ bs, while the second is at 70 to $80 \mathrm{~cm}$ bs. Both of these peaks are below the level at which artifacts are most common at a site level. As such, it is unclear if these peaks are cultural or natural in origin.

\section{Cultural Material}

\section{Native Ceramics}

\section{Investigations}

The 46 ceramic sherds recovered from shovel testing constitute the largest and most varied ceramic assemblage at any one site (Figure 32). The largest number of sherds were recovered from ST $14(n=16)$, ST $5(n=7)$, and ST $96(n=7)$. Ceramic sherd density is 2.9 per positive shovel test. The plain/decorated sherd ratio is 4.1. 


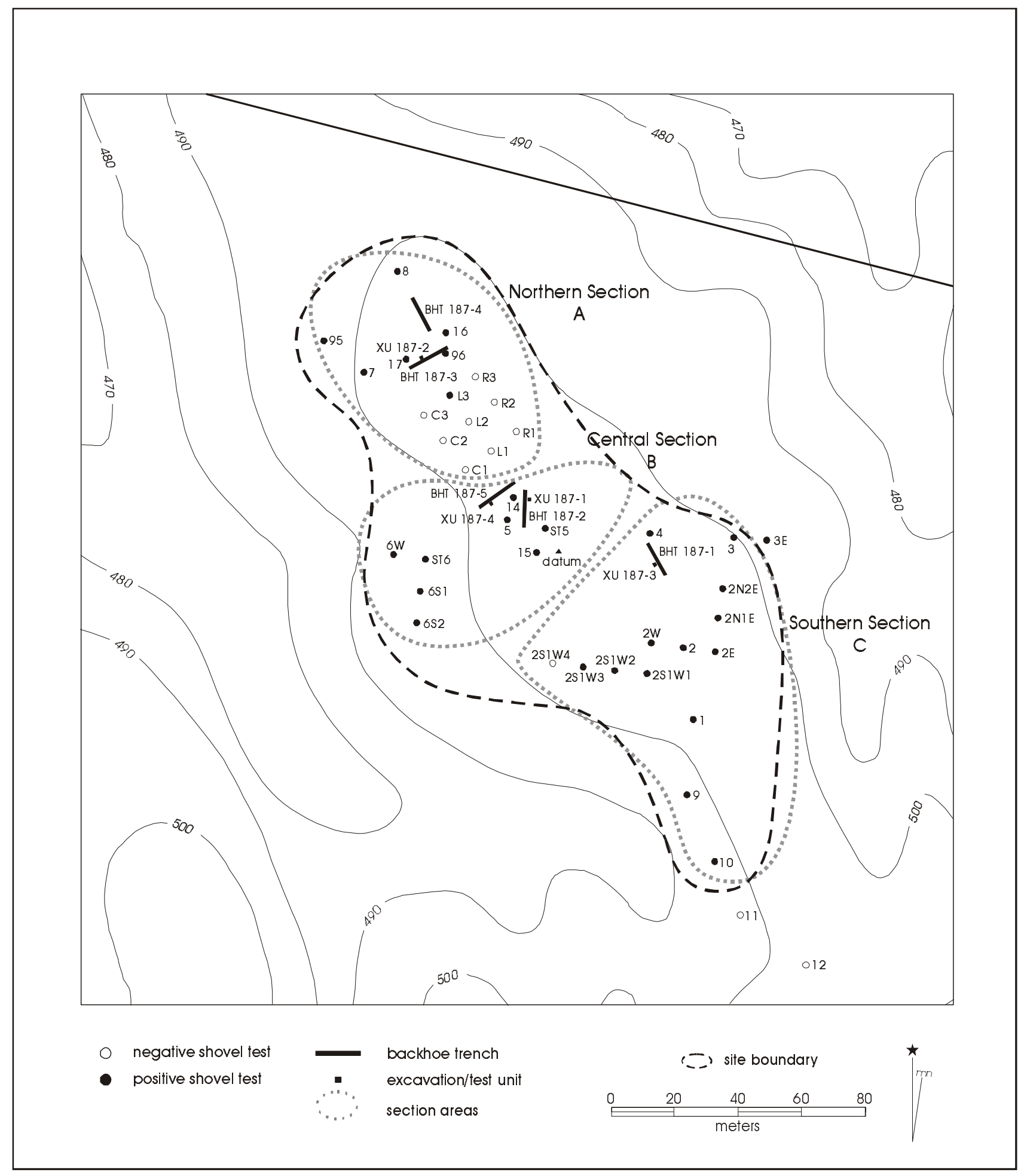

Figure 31. Site map-41LR187. 


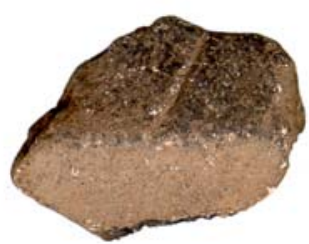

a

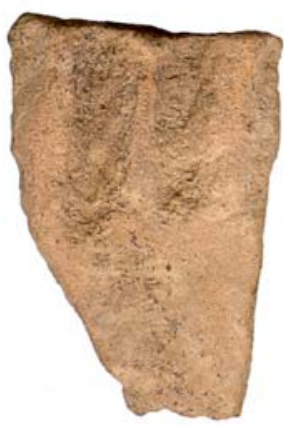

d

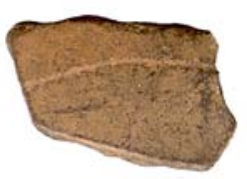

g

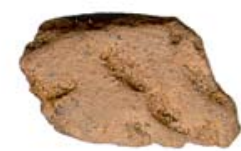

b

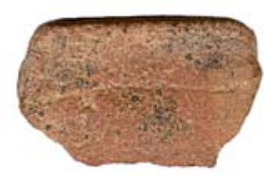

e

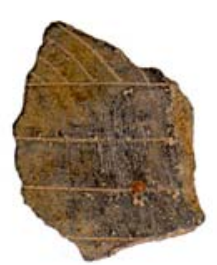

c

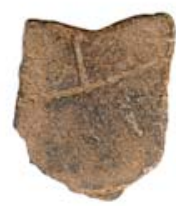

f
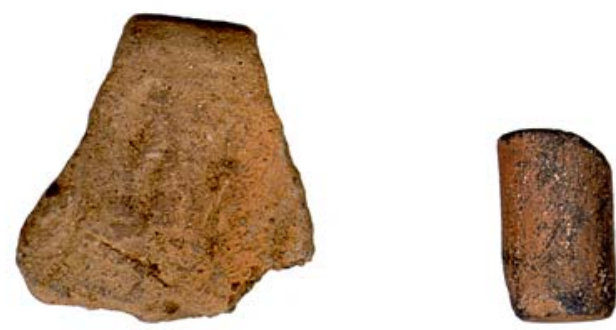

j

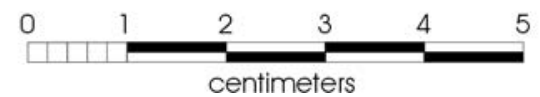

Figure 32. Examples of native ceramics recovered from site 41LR187. a) engraved body sherd, XU 1, 20-30 cm bs; b) punctated body sherd, XU 1, 20-30 cm bs; c) engraved body sherd, XU 1, 20-30 cm bs; d) appliquéd body sherd, XU 1, 30-40 cm bs; e) engraved rim sherd, XU 1, 30-40 cm bs; f) engraved body sherd, XU 1,30-40 cm bs; g) engraved body sherd, XU 1, $40-50 \mathrm{~cm}$ bs; h) punctated body sherd, XU 2, 50-60 cm bs; i) punctated rim sherd, BHT 1, backdirt; j) Red River pipe sherd — stem blunt end, XU 2, 40-50 cm bs. 
More than $95 \%$ of the ceramic sherds are tempered with grog, and one red-slipped sherd has bone-temper. Another $16 \%$ of the grog-tempered sherds also have bone temper inclusions, and two other sherds (4.5\%) also have grit temper. The overall proportion of sherds with bone temper is $17 \%$, slightly lower than 41LR186. Like the ceramics from 41LR186, these sherds are from wellmade and coiled vessels, with a mean body wall thickness of $6.7 \mathrm{~mm}$ (range of 3.1-11.2 mm); the flat base sherds range from 11.2 to $13.9 \mathrm{~mm}$ in thickness.

Most of the sherds are from vessels that have been fired in an oxidizing environment (59\%), including sherds from vessels that were incompletely oxidized during firing. The proportion of sherds from vessels fired in a reducing environment is only $41 \%$, compared to $67 \%$ at the nearby, but probably slightly earlier site of 41LR186. Among the decorated sherds, $63 \%$ are from vessels fired in an oxidizing environment. The two plain rims (ST 14, 60-71 cm bs), however, are from two different vessels that were fired in a reducing environment.

The nine decorated sherds include four red-slipped, one engraved, one parallel brushed, two punctated, and one incised sherd. The red-slipped body and base sherds have a hematite-rich clay slip only on the exterior sherd surface; two are tempered with grog (ST 5, 40-60 cm bs and ST 7, 20-40 cm bs), one with grogbone (ST 96, 20-40 cm bs), and the other with bone (ST 3, 20-40 cm bs). These sherds are probably from several different plain red-slipped bowls, although the presence of plain red-slipped rims precludes a definitive determination. Plain red-slipped and grog-tempered ceramics are relatively abundant in Middle Caddoan times in much of Northeast Texas, including the middle reaches of the Red River basin (Perttula 1997).

The engraved sherd (FS5, 60-80 cm bs), also grogtempered, has only a single indeterminate engraved line. The parallel brushed sherd from ST $4(0-20 \mathrm{~cm}$ bs) may be from an imported vessel from the lower Sulphur River basin or the middle and lower Big Cypress Creek basin because brushed ceramic vessels (tempered with grog) of any kind are virtually unknown in the Red River basin during the prehistoric era. Brushed vessels and sherds are quite common, however, in parts of the Sulphur River and Big
Cypress Creek basins, well to the southeast of Camp Maxey.

The two punctated sherds (ST 7, 60-70 $\mathrm{cm}$ bs and ST 14, 40-60 cm bs) have tool punctated rows, probably on the body of jars. Both sherds, tempered with grog and bone, are from vessels incompletely oxidized during firing, and range in thickness from 5.9-6.4 mm.

The one incised sherd (ST 14, 40-60 cm) has at least three parallel incised lines on a body sherd. It is tempered with grog, and its thin body walls $(5.1 \mathrm{~mm})$ suggest it probably is from a small bowl.

\section{Investigations}

The sample of Caddoan ceramics found during the archaeological survey (Lyle et al. 2001) is supplemented by additional information collected during testing. This additional data includes 273 sherds, four pieces of fired clay, and one pipe sherd. Among the sherds, there are seven decorated rims, 25 decorated body sherds, 11 plain rims, 191 plain body sherds, and 18 plain base sherds. The plain/decorated sherd ratio is 6.88 . About 16.6 percent of the sherds have been smoothed and/or burnished on one or both vessel surfaces, suggesting that the ceramic assemblage is well preserved. The assemblage is dominated by sherds with grog temper, for both the plain and decorated pieces, and sherds that are from vessels that have been fired in a reducing environment (Table 3).

There are seven decorated rims and 25 decorated body sherds. As only 39 percent of all the rims $(n=18)$ are decorated, many of the vessels at 41LR187 were probably completely undecorated. Of those that were decorated, 11 have engraving (including three rims), 11 are punctated, seven are red-slipped, and there are single examples of incised, incised-punctated, and appliquéd sherds in the assemblage (see Figure 32 for examples).

Few of the engraved sherds have more than a single indeterminate engraved line $(n=4)$ on a body sherd. One of these sherds (XU 2, 20-30 cm) also has a red slip on the exterior vessel surface. One other body sherd has two parallel-engraved lines (XU 1, 0-10 cm bs), and a body sherd from XU $1(30-40 \mathrm{~cm}$ bs [Figure 32f]) has a small rectilinear element. Another 
Table 3. Ceramic assemblage from 41LR187

\begin{tabular}{|c|c|c|c|c|c|c|c|c|c|}
\hline Temper & Base & $\begin{array}{r}\text { Plain } \\
\text { Rim } \\
\end{array}$ & $\begin{array}{c}\text { Decorated } \\
\text { Rim } \\
\end{array}$ & $\begin{array}{c}\text { Decorated } \\
\text { Body }\end{array}$ & $\begin{array}{l}\text { Plain } \\
\text { Body }\end{array}$ & Ox+ & IO & $\mathbf{R}$ & R-O \\
\hline $\mathrm{G}^{*}$ & 10 & 7 & 2 & 11 & 100 & 15 & 37 & 26 & 50 \\
\hline G-B & 2 & 2 & - & 5 & 25 & 3 & 4 & 9 & 16 \\
\hline $\mathrm{G} / \mathrm{SP}$ & 4 & - & 2 & 1 & 24 & 4 & 2 & 8 & 17 \\
\hline G-H & - & - & 2 & 1 & 15 & - & 4 & 4 & 10 \\
\hline B & - & 1 & 1 & 3 & 11 & - & - & 8 & 8 \\
\hline G-B-H & - & 1 & - & - & 4 & - & - & 1 & 4 \\
\hline G-Gt & 1 & - & - & 3 & 2 & - & - & 1 & 4 \\
\hline Gt & 1 & - & - & - & 1 & - & - & 1 & 1 \\
\hline B-H & - & - & - & 1 & 1 & - & - & 2 & - \\
\hline G-Gt-B & - & - & - & - & 2 & - & - & - & 2 \\
\hline B-Gt & - & - & - & - & 2 & - & - & 1 & 1 \\
\hline $\mathrm{B} / \mathrm{SP}$ & - & - & - & - & 1 & - & - & 1 & - \\
\hline G-B/SP & - & - & - & - & 1 & - & - & & 1 \\
\hline G-H/SP & - & - & - & - & 1 & - & - & & 1 \\
\hline S & - & - & - & - & 1 & 1 & - & - & - \\
\hline
\end{tabular}

${ }^{*} \mathrm{G}=$ grog; $\mathrm{G}-\mathrm{B}=$ grog-bone; $\mathrm{G} / \mathrm{SP}=$ grog and sandy paste; $\mathrm{G}-\mathrm{H}=$ grog-hematite; $\mathrm{B}=$ bone; $\mathrm{G}-\mathrm{B}-\mathrm{H}=$ grog-bone-hematite; $\mathrm{G}-\mathrm{Gt}=$ grog-grit; $\mathrm{Gt}=$ grit; $\mathrm{B}-\mathrm{H}=$ bone-hematite; $\mathrm{G}-\mathrm{Gt}-\mathrm{B}=$ grog-grit-bone; $\mathrm{B}-\mathrm{Gt}=$ bone-grit; $\mathrm{B} / \mathrm{SP}=$ bone and sandy paste; $\mathrm{G}-\mathrm{B} / \mathrm{SP}=$ grog-bone and sandy paste; $\mathrm{G}-\mathrm{H} / \mathrm{SP}=$ grog-hematite and sandy paste; $\mathrm{S}=$ shell

$\mathrm{OX}+=$ oxidized during firing; $\mathrm{IO}=$ incompletely oxidized during firing; $\mathrm{R}=$ fired in a reducing environment; $\mathrm{R}-\mathrm{O}=$ fired in a reducing environment, but cooled in a high oxygen environment.

engraved sherd, from a carinated bowl, has a diagonal line, possibly part of a diagonal or triangular engraved element that would have encircled the vessel rim (see Jackson et al. 2000:59, 89). Three rims have one or two horizontal engraved lines below the lip. The rims are direct, with either flat or rounded lips. The final engraved sherd is from a burnished bottle (XU 1, $20-30 \mathrm{~cm}$ bs [Figure 32c]). It has at least four vertical and finely engraved lines in a zone separating a set of concentric engraved lines; this decorative pattern would have been repeated at least four times around the body of the bottle. The combination of fine vertical and curvilinear engraved lines is stylistically similar to Holly Fine Engraved (Suhm and Jelks 1962: Plate 40e, g), made between ca. A.D. 900-1300, but the motif is also noted on non-Holly Fine Engraved bottles and beakers in Middle Caddoan contexts at the ca. A.D. 1150-1400 Oak Hill Village site (Rogers and Perttula 1999).

The punctated sherds include both tool and fingernail punctated decorations on the vessel body (probably cooking jars). The two tool punctated sherds are from XU 1 (50-60 cm bs, body sherd) and XU 2 (50-60 $\mathrm{cm}$ bs, body sherd [Figure 32h]); the latter has 2-3 rows of punctations, while the former has randomly placed tool punctations. There are two rims and seven body sherds with fingernail punctations. One from BHT 2 (direct, with a rounded lip) has at least one oblique row, while the other (BHT 1) is a jar with a series of vertical rows across the rim. The body sherds with fingernail punctations may have been placed either in rows $(n=3)$, or randomly on the vessel body $(n=4)$.

Red-slipped sherds comprise 22 percent of the decorated sherds from 41LR187, and include six body sherds and one rim sherd (XU 1, 40-50 cm bs). The latter is from a bone-tempered bowl or carinated bowl, and has a direct rim and a flat lip. Red-slipped vessels are common in Middle Caddoan contexts in the middle reaches of the Red River basin, and at the Sanders site (41LR2) (Jackson et al. 2000). All the body and rim sherds have the red slip applied only to the exterior vessel surface, and at least three of the body sherds (one from the northern, central, and eastern site areas) appear to be from red-slipped bottles. 
The one incised body sherd (XU 2, 30-40 cm bs) has a single broad incised line. The decorative element is indeterminate, but it is possible that the incised line decoration horizontally encircles the vessel (a bowl or small jar?). One rim in the central site area (XU 4, 20-30 cm bs) has an incised-punctated decoration consisting of three horizontal incised lines above a row (or zone) of tool punctations? The rim is direct, with a rounded lip, and is probably from a bowl or carinated bowl. Another sherd from the central area, a body sherd (XU 1, 30-40 cm bs [Figure 32d]), has at least three parallel (possibly vertically oriented) rows of appliquéd-pinched ridges; each ridge is ca. $4 \mathrm{~mm}$ wide. Similar kinds of decorated sherds have been described from the generally contemporaneous Sanders site (41LR2), a few miles west of Camp Maxey (Jackson et al. 2000:141).

The plain rim sherds, from a minimum of seven vessels, are uniformly rather small in size, and orifice diameters could not be estimated on any of them. Sixty-three percent of the rims are tempered only with grog (see Table 3), and others have burned bone or crushed hematite pieces added to the paste. Rim profiles were only identifiable on seven of the 11 examples from 41LR187. Six of these are direct. The other, from XU $2(40-50 \mathrm{~cm} \mathrm{bs})$, has an inverted profile and a flat lip, and is from a plain shallow bowl. More than 44 percent of the rims have a flat lip and the others are rounded. Two rims in the central area, one with grog temper (XU 1, 30-40 cm bs), and the other with grogbone tempering (BHT 2), are between 9.3-11.7 mm in thickness. They are from large Williams Plain vessels. The other rims range only from $3.9-7.0 \mathrm{~mm}$ in thickness, and are apparently from a smaller class of plain vessels. The mean wall thickness of the plain rims is $6.61 \pm 1.48 \mathrm{~mm}$, slightly thicker than the decorated rim sherds.

Among the plain body sherds, there are 15 different temper and/or paste combinations (see Table 3). This is an impressive diversity, and suggests that a variety of vessels of different forms and functions (i.e., cooking, storage, holding liquids, serving foods, etc.) were manufactured by the Middle Caddoan groups living at the site. Grog-tempered vessel sherds are most abundant (see Table 3), followed by grogbone-tempered, grog-tempered vessel sherds with a sandy paste, and sherds with grog and crushed hematite. The use of grog or crushed sherds as the principal tempering agent probably helped the 41LR187 vessels withstand the thermal and mechanical stresses of repeated heating and cooling, as well as regular use, and they would have been durable and had good thermal conductivity.

The vessel body sherds generally range from 4-10 mm in thickness, although most are less than $8 \mathrm{~mm}$ thick (Table 4). Although few in numbers, the grog-gritbone-tempered and grog-bone-tempered/sandy paste sherds, by contrast, are very thick $(9.85 \pm 0.45 \mathrm{~mm}$ and $9.9 \mathrm{~mm}$, respectively). They are probably from large Williams Plain vessels. Schambach (1998) has commented on the fact that Williams Plain vessels are not necessarily only tempered with grog, but had other paste constituents or commonly had a sandy paste.

The 18 plain base sherds are from a minimum of 13 different vessels. About 94 percent have been tempered with grog, and one only has crushed rock or grit inclusions (see Table 3). Two others have grog and bone tempering, and four have a naturally sandy paste (i.e., the Caddo potters selected a sandy clay for vessel manufacture). The bases are flat and thick disks, with a mean thickness of $11.55 \pm 1.27 \mathrm{~mm}$. As with the site as a whole (see Table 3), the majority of the bases ( 72 percent) are from vessels that have been fired in a reducing environment.

The single Red River long-stemmed pipe sherd (Figure 32j) is from XU 2 (40-50 cm bs) in the northern part of the site. It is the blunt end of the stem, opposite the bowl from the stem opening or mouthpiece. The sherd is $18.9 \mathrm{~mm}$ in length, and has a 10.7 $\mathrm{mm}$ stem diameter and a $7.4 \mathrm{~mm}$ stem hole diameter. The pipe has finely crushed grog tempering, with 3.0 mm thick walls, and they have been well smoothed. Similar blunt-ended long-stemmed pipes have been recovered from Middle Caddoan contexts (ca. A.D. 1250-1375) at the Hurricane Hill site (41HP106) on the South Sulphur River (Perttula 1999:Figure 9-27b) and the A. C. Mackin site (41LR36) on Big Pine Creek (Mallouf 1976). The stem diameter of the 41LR187 pipe is also comparable to Caddoan ceramic pipe assemblages at the Hurricane Hill site and the Middle Caddoan Oak Hill Village (41RK214) 
Table 4. Thickness of the plain and decorated body sherds

\begin{tabular}{lc}
\hline Temper and Paste Classes & Mean Thickness (mm and sd) \\
\hline Grog & $7.05 \pm 1.08$ \\
Grog-Bone & $7.24 \pm 1.03$ \\
Grog-Sandy Paste & $7.33 \pm 1.01$ \\
Grog-Bone-Hematite & $7.10 \pm 0.35$ \\
Grog-Hematite & $6.98 \pm 1.23$ \\
Grog-Hematite-Sandy Paste & 6.5 \\
Bone & $5.83 \pm 1.28$ \\
Bone-Hematite & $5.25 \pm 1.05$ \\
Bone-Sandy Paste & 7.4 \\
Bone-Grit & $6.75 \pm 0.95$ \\
Grog-Grit & $6.40 \pm 0.75$ \\
Grog-Grit-Bone & $9.85 \pm 0.45$ \\
Grog-Bone-Sandy Paste & 9.9 \\
Grit & 8.4 \\
Shell & 6.1 \\
\hline
\end{tabular}

site (Rogers and Perttula 1999), suggesting the manufacture of relatively large and thick long-stemmed pipes during the Middle Caddoan period in the region.

The four pieces of fired clay are from the central part of the site, specifically XU 4 and BHT 5. The pieces weigh $12.5 \mathrm{~g}$, and 75 percent are oxidized. They likely represent evidence for an episode of burning in this area, either from a clay-lined hearth or the mud plastering from a structure.

Taken as a whole, the ceramics from the different areas of the site (in particular the north and central areas) are probably from a single Middle Caddoan component with separate but qualitatively similar habitation areas (Table 5). In terms of the principal decorative elements, there is little significant difference between the two areas, and the proportions and kinds of engraved, redslipped, and fingernail punctated sherds are very much the same.

Keeping in mind the relatively small size of the ceramic assemblages in these two site areas, the only obvious differences between the central and northern parts of $41 \mathrm{LR} 187$ are in the proportions of grog or bone aplastics in the paste of the vessel sherds (Table 5). The northern area has more vessel sherds with only grog tempering, as well as more sherds with a sandy paste or crushed pieces of hematite. Conversely, grogbone-tempered and bone-tempered sherds are more common in the central area, and the proportion of sherds with some amount of bone temper is more than twice as frequent as in the northern area ceramic assemblage. Given the technological comparisons to be discussed below, and the apparent increase in the use of bone tempering from Early Caddoan to Middle Caddoan contexts at Camp Maxey, this suggests that the ceramics in the northern area at 41LR187 may represent the initial settlement of the site during the Middle Caddoan period, with the central area slightly

Table 5. Ceramic comparisons, North and Central areas, 41LR187

\begin{tabular}{lll}
\hline Principal Temper & North & Central \\
\hline Grog & $59.6 \% *$ & $51.70 \%$ \\
Grog-Sandy Paste & $15.80 \%$ & $11.20 \%$ \\
Grog-Bone & $5.30 \%$ & $16.90 \%$ \\
Grog-Hematite & $10.50 \%$ & $6.80 \%$ \\
Bone & $0.00 \%$ & $5.90 \%$ \\
& & \\
All sherds with Bone & $12.30 \%$ & $28 \%$ \\
\hline
\end{tabular}

Principal Decorative Elements

\begin{tabular}{lll}
\hline Engraved & $37.50 \%$ & $40.00 \%$ \\
Red-slipped & $25 \%$ & $20 \%$ \\
Punctated & $25 \%$ & $30 \%$ \\
\hline & & \\
& & \\
Sherd Density per $\mathrm{m}^{2}$ & 64 & 73.5 \\
\hline
\end{tabular}

* Based on body sherds. 
younger in age. Obviously, radiocarbon analyses from these two areas are needed to evaluate the veracity of this possible changing temporal patterning in temper choices.

\section{Lithics}

\section{Tools}

Twenty-nine stone tools were recovered from 41LR187. The assemblage consists of a Gary dart point preform, an untypeable dart point, an untypeable arrow point, two projectile point stems, eleven bifaces, one formal scraper, one expedient end scraper, five edge-modified flakes, and six cores.

The Gary dart point preform (Cat. No. 323-2) has a contracting stem with a rounded base. It is manufactured from medium-grained gray quartzite. The untypeable dart point (Cat. No. 328-1 [see Figure 25]) has a distal break, which has been reworked and has use wear consistent with an adze. The dart point still exhibits an expanding stem with a straight base and diminutive barbs. It is manufactured from a finegrained yellow quartzite. The untypeable arrow point (Cat. No. 331-1) appears incomplete with a single barb and a convex base. It is manufactured from a white chert. The two projectile point stems are probable from Gary dart points. Both are contracting with rounded bases and have widths consistent with other Gary dart points recovered during the project.

Of the eleven bifaces four are complete and seven are fragments. Two of the four complete bifaces are early stage reduction medium-grained quartzite bifaces. The third biface is a siliceous pebble tool of tan chert with $25 \%$ cortex remaining. The fourth complete biface appears to be a practice blank with a deep side notch removed from a single side. It is manufactured from red jasper. Among the seven biface fragments, three are distal fragments, two are medial fragments, and two are indeterminate fragments.

The formal scraper is an end and side scraper made on heat-treated chert. All five of the edge-modified flakes are expedient tools manufactured from chert. Three of the flakes have use wear indicative of scraping activity. The remaining two flakes have indeterminate use wear, suggesting use as expedient multi-functional processing tools. The single expedient end scraper is on a small secondary flake (Cat. No. 146). Of note within the six cores is a single polyhedral blade core (Cat. No. 147), and a bipolar core (Cat. No. 318-5).

The presence of the dart point fragments alongside the single arrow point suggests either a multiple component Archaic and Late Prehistoric site, or potentially a single component Woodland period occupation. Given the recovery of the extensive ceramic assemblage, the former is more plausible.

\section{Debitage}

A total of 381 debitage was recovered during the 19992000 survey and 2000 testing efforts at 41LR187. Of this total, 230 are chert, 11 are novaculite, three are silicified wood, 135 are quartzite, and two are quartz. Among the assemblage, six chert flakes and three quartzite flakes are heat-treated. This pattern suggests that, minimally, thermal alteration of stone raw materials to improve workability may have been of low importance at this site.

As at all of the sites in this study, chert and quartzite clearly dominate the debitage total. Of the 230 chert flakes, 116 are decorticate, 79 have $1-50 \%$ cortex, 26 have $51-99 \%$ cortex, and nine have $100 \%$ cortex. The mean thickness to length ratio for the chert debitage is 0.20 . Of the 135 quartzite flakes, 67 are decorticate, 33 have $1-50 \%$ cortex, 21 have $51-99 \%$ cortex, and 14 have $100 \%$ cortex. The mean thickness to length ratio for the quartzite debitage is 0.21 . These patterns indicate that the primary lithic activity, as reflected by the recovered debitage, was middle stage reduction and tool manufacture.

An itemization of the flake types among the chert debitage presents three angular debris flakes, four biface manufacture flakes, one biface resharpening flake, four biface thinning flakes, 60 core preparation flakes, 53 platform preparation flakes, and 105 indeterminate flakes. Among the quartzite, there are eight biface manufacture flakes, one biface thinning flake, one blade, 45 core preparation flakes, 40 platform preparation flakes, and 40 indeterminate flakes. These comparisons further indicate tool manufacture as the primary activity represented in the lithic assemblage. 
Debitage was encountered from $0-80 \mathrm{~cm}$ bs, with the greatest density ( $43 \%$ ) of flakes recovered within levels three and four, or $20-40 \mathrm{~cm}$ bs. Debitage density gently tapers off in levels five through eight (40-80 $\mathrm{cm}$ bs), with an abrupt termination below $80 \mathrm{~cm}$ bs. Based on the vertical distribution of this assemblage, a cultural zone is indicated from $20-40 \mathrm{~cm}$ bs.

Artifacts produced from non-local raw materials recovered from this site include novaculite, quartz, green cherts and gray cherts. Novaculite is generally associated with the Ouchita Mountains in Eastern Oklahoma and Western Arkansas. Similarly, quartz is indicative of an Ouchita Mountain source and may be encountered along the Red River. The green cherts are typically related to Oklahoma and may be encountered in Red River gravels. The gray cherts are typically associated with the Georgetown cherts of central Texas.

\section{LR202}

\section{Description}

Site 41LR202 is located in the northwestern portion of the facility approximately $700 \mathrm{~m}$ east and south of Pat Mayse Reservoir (see Figure 10 in supplement). The site is situated around a seasonal wetland atop an upland landform of Whakana series fine sandy loams and Whakana-Porum complex loams at 510-520 ft AMSL. The vegetation community surrounding the wetland consists of the Quercus stellata-Quercus marilandica-(Carya texana) Woodland class, providing roughly $15 \%$ ground surface visibility. The vegetation community of the wetland consists of the Fraxinus pennsylvanica-Ulmus americana Wetland Forest class (Figure 33).

Nine backhoe trenches, six excavation/test units, and 35 shovel tests were excavated to define the site (Figure 34 in supplement). Based on these data, the site measures approximately $350 \times 320-\mathrm{m}$, and covers an area of about $51,390 \mathrm{~m}^{2}$. Twenty-six shovel tests were placed on site. Eight (31\%) of the 26 were positive. Cultural material extends from $0-120 \mathrm{~cm}$ bs, with the greatest density (20\%) of provenienced artifacts encountered within levels three and four, or $20-40 \mathrm{~cm}$ bs.

\section{Discussion}

The site consists of a sparse scatter of cultural material around an apparent bog. The bog appears to be artificially drained to the south by a man-made drainage ditch. Comparison of historic maps of the project area suggests that this modification was made sometime subsequent to military possession of the property. A natural levee surrounds the bog on all but the southern side. The site appears impacted by an eastwest oriented abandoned road (see Figure 11 in supplement), which seems to have altered course both north and south of the bog. During the latter portion of the project, and before clearance was received to test the bog via coring, heavy rains inundated the bog (Figure 33) throughout the remainder of the field investigations. Recovered materials suggest that the site was utilized as a short-term open campsite 


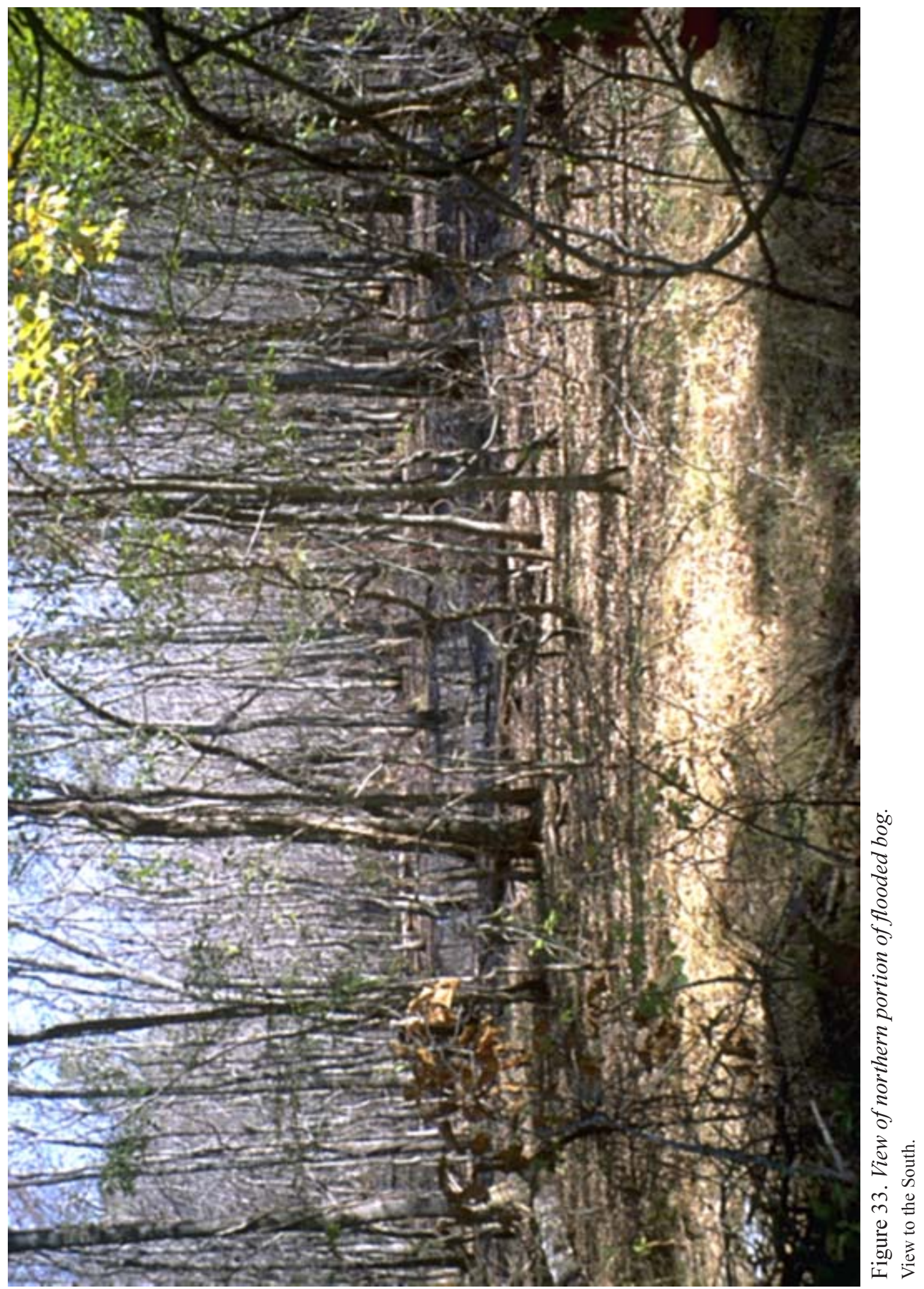




\section{Cultural Material}

\section{Native Ceramics}

No ceramics were recovered from the site in the survey phase of this project.

\section{Investigations}

Excavation unit $1(20-30 \mathrm{~cm}$ bs $)$ has a single plain shell-tempered body sherd. The sherd is thin $(5.0 \mathrm{~mm})$ and from a vessel that was incompletely oxidized during firing. The shell-tempered sherd found here implies that the site (and perhaps the bog area) was used after A.D. 1300, based on previous archeological investigations along the middle reaches of the Red River (Bruseth 1998; Perttula et al. 2001). This is one of the very few prehistoric sites at Camp Maxey indicative of Caddoan use of these lands between ca. A.D. 1300-1600 (Lyle et al. 2001:248).

\section{Lithics}

\section{Tools}

Two cores and a hammerstone comprise the entire tool assemblage recovered from 41LR202. All of the artifacts are manufactured from medium to coarse-grained quartzites with $50-90 \%$ cortex. Each of the cores was recovered unprovenienced from backhoe trench backdirt. The hammerstone exhibits battering along four margins and one distal end.

\section{Debitage}

A total of 36 debitage was recovered during the 1999-2000 survey and 2000 testing efforts at 41LR202. Of these items 15 are from Maxey II and 21 are from Maxey III. Of this total, 21 are chert and 15 are quartzite. Among the assemblage, none are heattreated. This pattern suggests that, minimally, thermal alteration of stone raw materials to improve workability may not have been implemented at this site.

As at all of the sites in this study, chert and quartzite clearly dominate the debitage total. Of the 21 chert flakes, 13 are decorticate, five have $1-50 \%$ cortex, one has $51-99 \%$ cortex, and two have $100 \%$ cortex. The mean thickness to length ratio for the chert debitage is 0.15 . This pattern is suggestive of late stage reduction and tool resharpening/rejuvenation. Of the 15 quartzite flakes, six are decorticate, four have
$1-50 \%$ cortex, four have $51-99 \%$ cortex, and one has $100 \%$ cortex. The mean thickness to length ratio for the quartzite debitage is 0.21 . The pattern for the quartzite flakes is more suggestive of middle stage reduction and tool production.

An itemization of the flake types among the chert debitage presents one biface rejuvenation flake, four core preparation flakes, one notching flake, eight platform preparation flakes, one uniface flake, and six indeterminate flakes. Among the quartzite, there are seven core preparation flakes, four platform preparation flakes, and four indeterminate flakes. These comparisons further indicate tool manufacture as the primary activity represented in the lithic assemblage.

Debitage was encountered from $0-120 \mathrm{~cm}$ bs, with the greatest density (33\%) of flakes recovered within levels one and two, or 0-20 cm bs. Debitage density gradually tapers off in levels three through twelve ( 20 $120 \mathrm{~cm} \mathrm{bs}$ ), with an abrupt termination below $120 \mathrm{~cm}$ bs. Based upon the vertical distribution of this assemblage, a cultural zone is indicated from $0-20 \mathrm{~cm}$ bs. 


\section{LR204}

\section{Description}

Site 41LR204 is located in the southwestern portion of the facility approximately $150 \mathrm{~m}$ west of an unnamed tributary to Sanders Creek (see Figure 10 in supplement). The site is situated atop an upland ridge landform of Woodtell series loams at 490-500 ft AMSL. The vegetation community consists of the Quercus stellata-Quercus marilandica-(Carya texana) Woodland class, providing roughly 20 percent ground surface visibility.

Four backhoe trenches, four excavation units, and 37 shovel tests were excavated to define the site boundary (Figure 35). Based on these data, the site measures approximately $125 \times 45-\mathrm{m}$, and covers an area of 4,625 square meters. Within the current site boundary, 25 shovel tests were excavated. Of these, 17 (68\%) shovel tests were positive. Cultural material extends from $0-80 \mathrm{~cm}$ bs, with the greatest density $(43 \%)$ of provenienced artifacts encountered within levels three and four, or $20-40 \mathrm{~cm}$ bs.

\section{Discussion}

Due to the spatial distribution of the artifacts recovered from 41LR204, it appears as though the majority of the site is situated across the property bounds onto COE property. This assertion is based upon the high recovery rate of cultural material from XU 1 relative to the remainder of the units. A reconnaissance of the extension of the ridge onto COE property revealed a surface scatter of lithic debitage approximately $40 \mathrm{~m}$ north of XU 1. The ridge continues for an additional 80-100 $\mathrm{m}$ and, near the toe of the ridge, a natural spring or seep occurs. These conditions would have proved favorable for prehistoric human occupation and further suggest continuation of the site northward.

Stratigraphy appeared intact and artifact recovery was relatively high in $\mathrm{XU} 1$, located in the northern portion of the site. The remainder of the site, however, did not share these qualities. As evidenced along the north wall of XU 2 (Figure 36), bioturbation was quite intrusive in the central and southern portions of the site.

\section{Cultural Material}

\section{Native Ceramics}

\section{Investigations}

Two shovel tests at the northern end of the site (ST 24-1, 0-20 cm and ST 24-18, 40-65 cm) contain prehistoric ceramic sherds. The three plain body sherds (6.7-7.4 $\mathrm{mm}$ in thickness) are tempered with grog (crushed sherds) and are from two separate vessels that have been fired in a reducing environment, but cooled in a high oxygen environment (Lyle et al. 2001:85)

\section{Investigations}

Only four plain grog-tempered body sherds are from 41LR204, three from XU 1 at the northern end of the site, and the fourth sherd from BHT 2, at the site's southern end.

The plain grog-tempered sherds are fairly thick (7.65 $\pm 0.50 \mathrm{~mm}$ ), and have no surface treatment. They represent a minimum of three vessels. Three of the four plain body sherds are from vessels that were fired in a reducing or low-oxygen environment, and the other is from a vessel fired in an oxidizing environment.

Previous analyses of the ceramics and overall artifact assemblage from 41LR204 suggested that the site may have been occupied during the Woodland period (Lyle et al. 2001:Table 12-1). The present evidence, albeit slim, does not alter that finding.

\section{Lithics}

\section{Tools}

Nine chipped lithic artifacts were recovered from excavations at 41LR204. The collection includes one projectile point stem fragment, four biface fragments, one indeterminate biface, a chopper, and two cores. The projectile point stem (Cat. No. 370-5) has a parallel stem, cortex at the stem base, and is a manufacture failure of tan chert. One of the biface fragments 


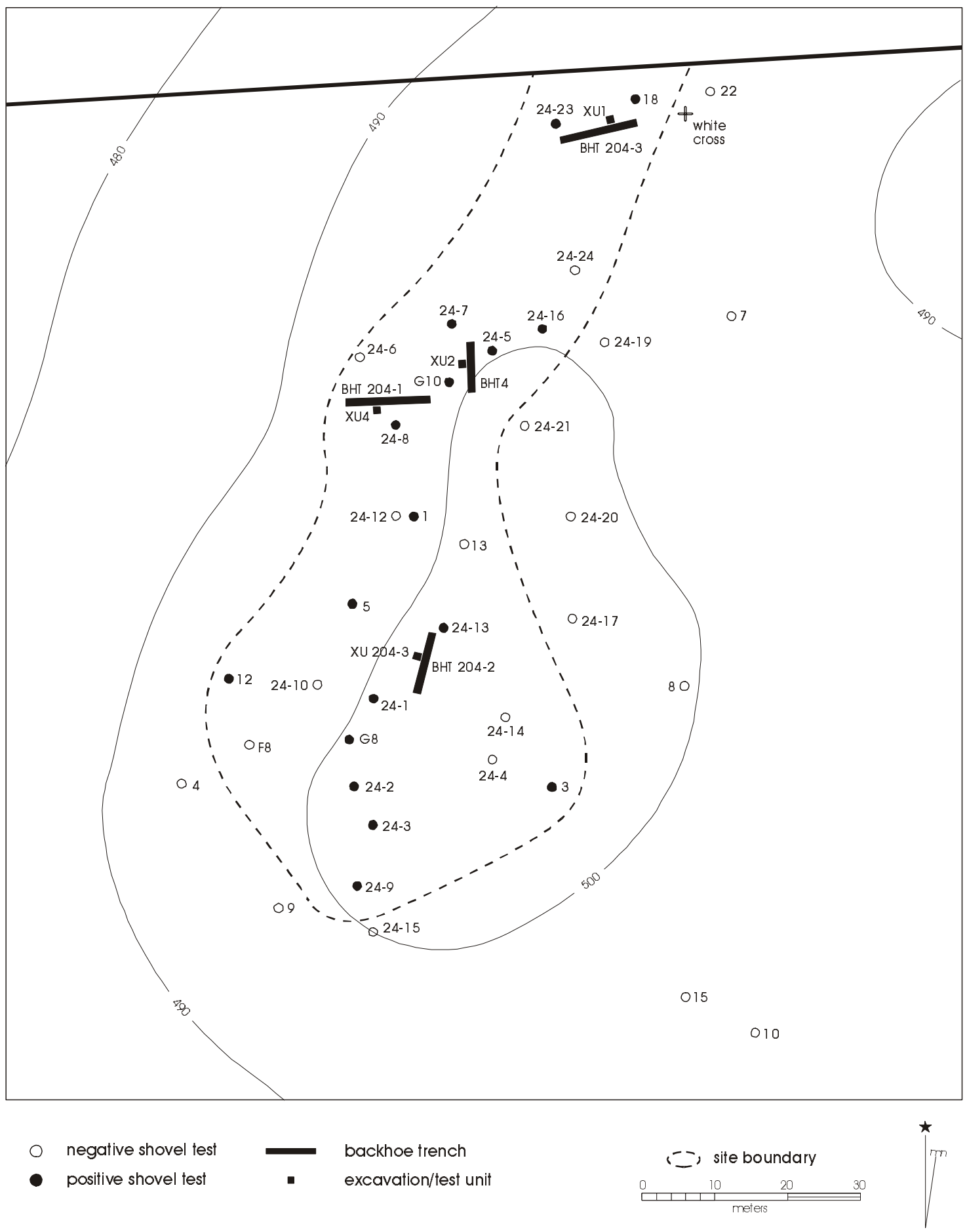

Figure 35. Site map - 41LR204. 


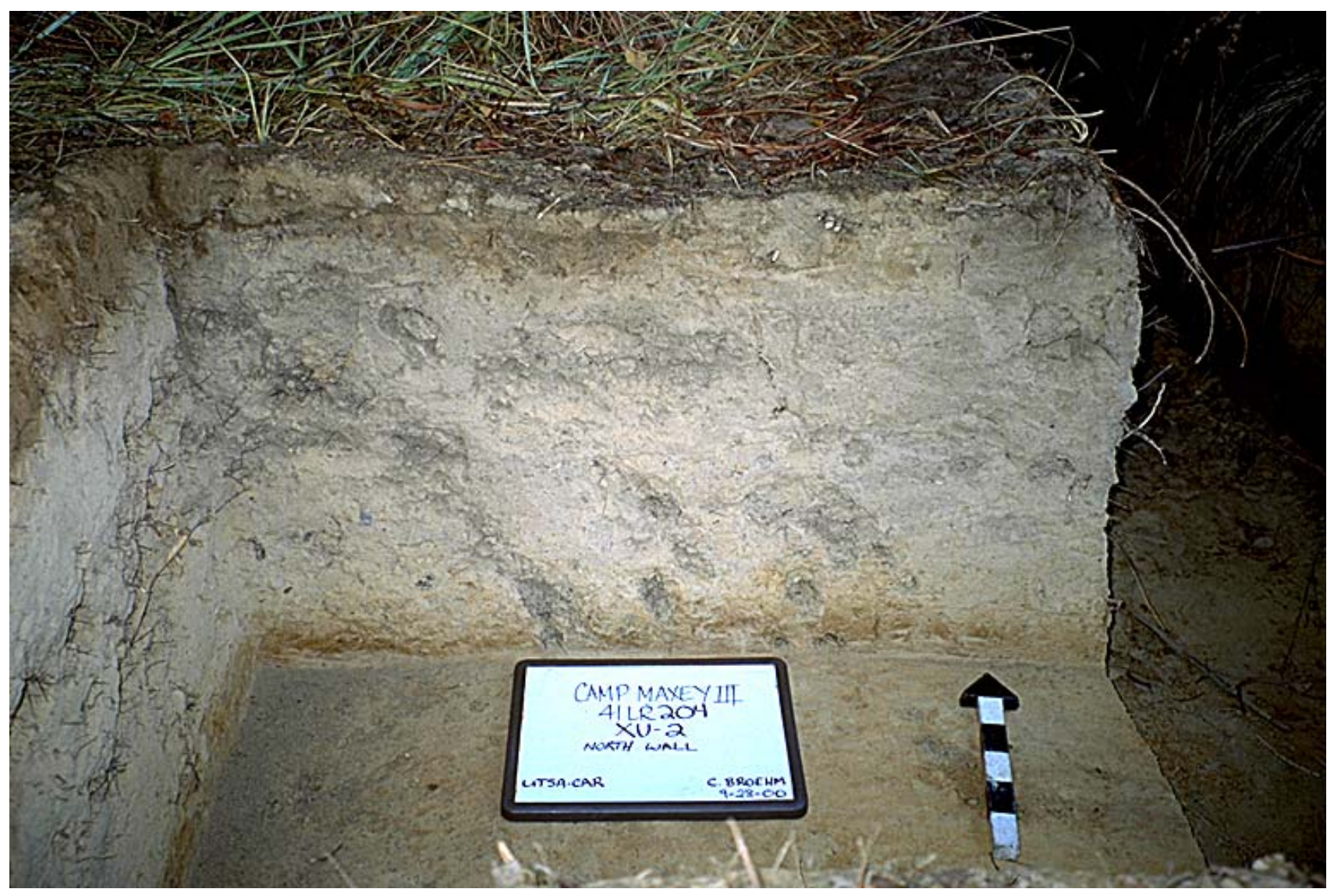

Figure 36. Wall Profile of 41LR204, XU 2, North Wall.

Note abundant bioturbation.

(Cat. No. 377-1) is an early stage reduction of medium-grained red quartzite with $25 \%$ cortex. The second biface fragment is a manufacture failure of white chert with cortex remaining at the flake platform. The third biface fragment is of red unheated quartzite. The final fragment is of heat-treated quartzite. It has a pointed base and may be a Gary preform (Cat. No. 367-3). The indeterminate biface (Cat. No. 329) is manufactured from a medium-grained gray quartzite. The chopper is of coarse-grained quartzite. It has a bifacially flaked edge and battering on its cortex-covered proximal end (Cat. No. 330). The two cores are all of quartzite with $30-90 \%$ cortex. No temporally diagnostic tools were recovered.

\section{Debitage}

A total of 200 debitage was recovered during the 19992000 survey and 2000 testing efforts at 41LR204. Of these items, 33 are from Maxey II and 167 are from
Maxey III. Of this total, 80 are chert, four are novaculite, one is silicified wood, 114 are quartzite, and one is quartz. Among the assemblage, five chert flakes and seven quartzite flakes are heat-treated. This pattern suggests that, minimally, thermal alteration of stone raw materials to improve workability may have been of low importance at this site.

As at all of the sites in this study, chert and quartzite clearly dominate the debitage total. Of the 80 chert flakes, 54 are decorticate, 20 have $1-50 \%$ cortex, four have $51-99 \%$ cortex, and two have $100 \%$ cortex. The mean thickness to length ratio for the chert debitage is 0.17 . Of the 114 quartzite flakes, 72 are decorticate, 30 have $1-50 \%$ cortex, eight have $51-99 \%$ cortex, and four have $100 \%$ cortex. The mean thickness to length ratio for the quartzite debitage is 0.19 . These patterns indicate that the primary lithic activity, as reflected by the recovered debitage, was middle to late stage reduction and tool manufacture/rejuvenation. 
An itemization of the flake types among the chert debitage presents five biface manufacture flakes, one biface rejuvenation flake, two biface resharpening flakes, four biface thinning flakes, 18 core preparation flakes, 20 platform preparation flakes, and 30 indeterminate flakes. Among the quartzite, there are four biface manufacture flakes, two biface rejuvenation flakes, one biface resharpening flake, three biface thinning flakes, one uniface flake, one core flake, 32 core preparation flakes, 27 platform preparation flakes, and 43 indeterminate flakes. These comparisons further indicate tool manufacture and maintenance as the primary activities represented in the lithic assemblage.

Debitage was encountered from $0-80 \mathrm{~cm}$ bs, with the greatest density (43\%) of flakes recovered within levels three and four, or 20-40 cm bs. Debitage density gradually tapers off in levels five through eight (40$80 \mathrm{~cm} \mathrm{bs}$ ), with an abrupt termination below $80 \mathrm{~cm}$ bs. Based upon the vertical distribution of this assemblage, a cultural zone is indicated from $20-40 \mathrm{~cm}$ bs.

Artifacts produced from non-local raw materials recovered from this site include novaculite, quartz, and gray cherts. Novaculite is generally associated with the Ouchita Mountains in Eastern Oklahoma and Western Arkansas. Similarly, quartz is indicative of an Ouchita Mountain source and may be encountered along the Red River. The gray cherts are typically associated with the Georgetown cherts of central Texas.

\section{LR207}

\section{Description}

Site 41LR207 is located in the west-central portion of the facility along the left descending bankline of an unnamed tributary to Sanders Creek (see Figure 10 in supplement). The site is situated atop an upland ridge landform of Whakana-Porum series loams at 500-510 $\mathrm{ft}$ AMSL. The vegetation community consists of the Quercus stellata-Quercus marilandica-(Carya texana) Woodland and Quercus nigra-Ulmus americana Woodland classes, providing roughly $0 \%$ ground surface visibility.

Three backhoe trenches, three excavation units, and 37 shovel tests were excavated to define the site boundary (Figure 37). Based on these data, the site measures approximately $110 \times 60-\mathrm{m}$, and covers an area of about 5,720 square meters. Twenty-one shovel tests were placed within the current site boundary. Eleven (52\%) of these 21 were positive. Cultural material extends from $0-80 \mathrm{~cm}$ bs, with the greatest density $(36 \%)$ of provenienced artifacts encountered within levels one and two, or 0-20 cm bs.

\section{Discussion}

This site sits atop an upland landform, which is dissected by two drainages (Figure 37). Erosional forces are probably impacting the prehistoric component as is evidenced by the proximity of the positive shovel tests to the current gullies and the active nature of the upland runoff evidenced during heavy rains. The sparse nature of the artifact assemblage and lack of native ceramics, suggest that the site was single or multiple component pre-ceramic open campsite.

\section{Cultural Material}

\section{Native Ceramics}

No ceramics were recovered during either phase of investigations. 


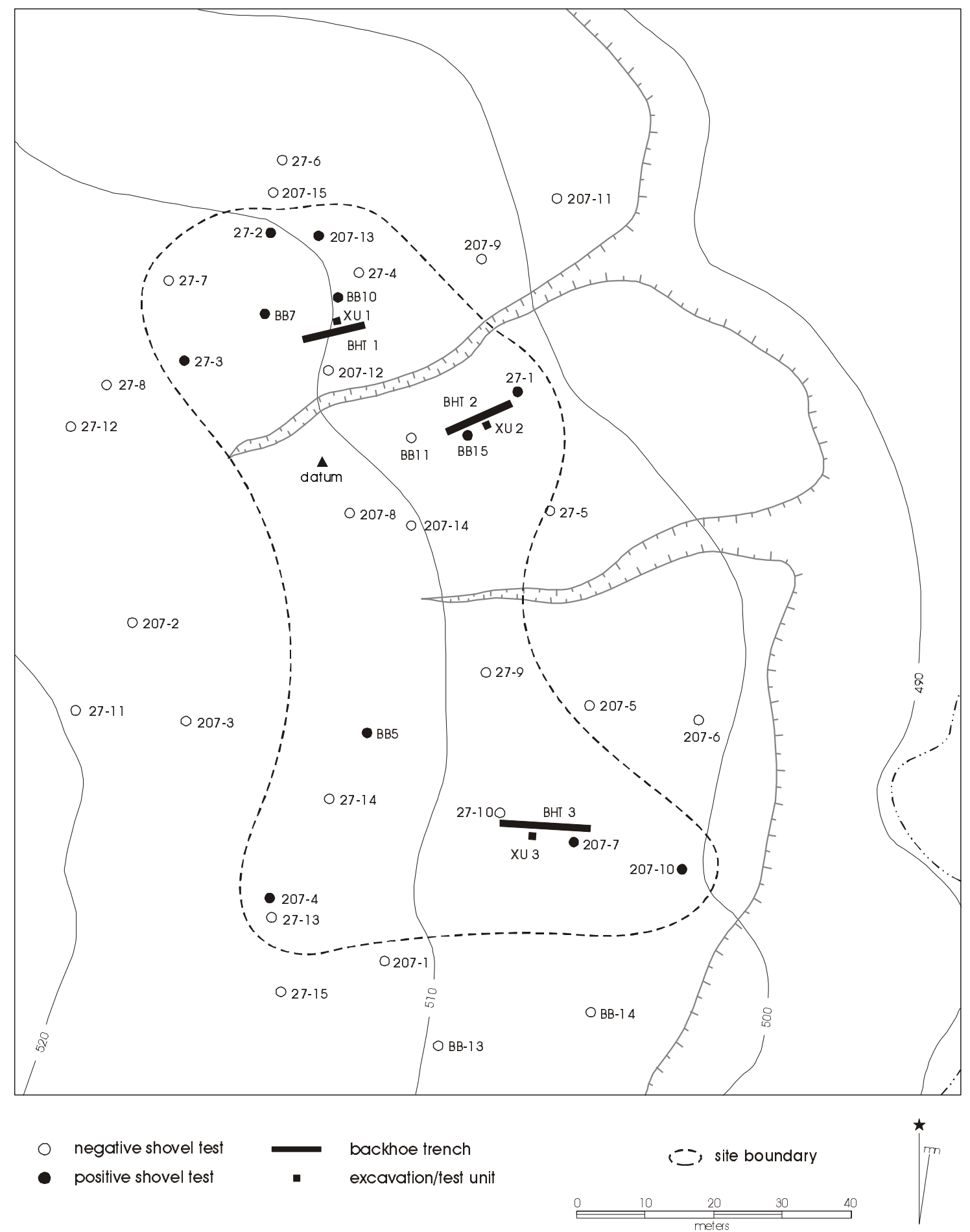

Figure 37. Site map - 41LR207. 


\section{Lithics}

\section{Tools}

A single indeterminate biface fragment was recovered from 41LR207. The manufacture failure fragment is manufactured from a coarse-grained yellow quartzite. The fragment was recovered from $40-50 \mathrm{~cm}$ bs in an excavation unit (XU 1; see Figure 36). This single fragment is not temporally diagnostic.

\section{Debitage}

A total of 84 debitage was recovered during the 19992000 survey and 2000 testing efforts at 41LR207. Of this total, 25 are chert, four are novaculite, one is silicified wood, 53 are quartzite, and one is quartz. Among the assemblage, one chert flake and one quartzite flake are heat-treated. This pattern suggests that, minimally, thermal alteration of stone raw materials to improve workability may have been of low importance at this site.

As at all of the sites in this study, chert and quartzite clearly dominate the debitage total. Of the 25 chert flakes, 17 are decorticate, seven have $1-50 \%$ cortex, and one has $100 \%$ cortex. The mean thickness to length ratio for the chert debitage is 0.16 . Of the 53 quartzite flakes, 34 are decorticate, 11 have $1-50 \%$ cortex, six have $51-99 \%$ cortex, and two have $100 \%$ cortex. The mean thickness to length ratio for the quartzite debitage is 0.17 . These patterns indicate that the primary lithic activity, as reflected by the recovered debitage, was late stage reduction and tool production/rejuvenation.

An itemization of the flake types among the chert debitage presents three biface manufacture flakes, one biface thinning flake, five core preparation flakes, five platform preparation flakes, and 11 indeterminate flakes. Among the quartzite, there are four biface manufacture flakes, 26 core preparation flakes, ten platform preparation flakes, and 13 indeterminate flakes. These comparisons further indicate tool manufacture as the primary activity represented in the lithic assemblage.
Debitage was encountered from 0-60 cm bs, with similar densities (30-32\%) of flakes recovered within levels one through six, or 0-60 cm bs. Debitage density drops considerably below $60 \mathrm{~cm}$ bs, with only five flakes recovered from $60-80 \mathrm{~cm}$ bs. Based upon the vertical distribution of this assemblage, no definable stratification of discrete cultural deposits is evident.

Artifacts produced from non-local raw materials recovered from this site include novaculite, quartz, and gray cherts. Novaculite is generally associated with the Ouchita Mountains in Eastern Oklahoma and Western Arkansas. Similarly, quartz is indicative of an Ouchita Mountain source and may be encountered along the Red River. The gray cherts are typically associated with the Georgetown cherts of central Texas. 


\section{LR208}

\section{Description}

Site 41LR208 is located in the west-central portion of the facility along the right descending bankline of an unnamed tributary to Sanders Creek (see Figure 10 in supplement). The site is situated atop an upland ridge landform of Whakana series fine sandy loams at 490$500 \mathrm{ft}$ AMSL. The vegetation community consists of the Quercus nigra-Ulmus americana Woodland and Schizachyrium scoparium Herbaceous classes, providing roughly $10 \%$ ground surface visibility.

Seven backhoe trenches, five excavation/test units, and 19 shovel tests were excavated to define the site boundary (Figure 38). Based on these data, the site measures approximately $70 \times 50-\mathrm{m}$ and covers an area of about 2,195 square meters. A total of 17 shovel tests were placed within the site boundary. Of this number, $15(88 \%)$ were positive. Cultural material extends from $0-60 \mathrm{~cm} \mathrm{bs}$, with the greatest density $(45 \%)$ of provenienced artifacts encountered within levels one and two, or $0-20 \mathrm{~cm}$ bs.

\section{Discussion}

This is a heavily disturbed site that lies at the boundary of a large open savanna of little bluestem and a woodland riparian zone along an intermittent stream. Military activity is evident in the form of a semi-circular trench spanning the width of the southern portion of the site and excavated to approximately 100 $\mathrm{cm}$ bs. Probable military-era debris consisting of barbed wire and tin sheeting litter the ground surface. Testing efforts focused north of the disturbed, trenched area, recovering moderate amounts of burned rock and lithic debitage. The absence of native ceramics and presence of the reworked Yarbrough dart point (recovered during the survey phase) and the quarry blank or preform suggests an open campsite of the Archaic era, possibly Late Archaic.

Sediment susceptibility samples were collected from $\mathrm{XU} 2$, from 0 to $50 \mathrm{~cm}$ bs, at $10-\mathrm{cm}$ intervals. As detailed in Appendix B, the presence of ferrous materi- als in these samples in levels 1 and 3 resulted in extremely high values, and thus rendered the susceptibility column difficult to interpret. Ferrous inclusions, present in the sediments as a result of natural processes, in effect obscured any potential cultural patterning.

\section{Cultural Material}

\section{Native Ceramics}

No ceramics were recovered during either phase of investigations.

\section{Lithics}

\section{Tools}

The stone tool assemblage consists of a Yarbrough dart point, a biface blank, and two biface fragments. The Yarbrough dart point has a distal break and has been reworked. It is manufactured from a mediumgrained gray quartzite. The biface blank (see Figure 25, LR208) is heat-treated and manufactured from a medium-grained gray quartzite. One of the biface fragments is a distal, probable dart point fragment manufactured from gray chert. The remaining specimen is a wedge-shaped fragment of fine-grained quartzite.

\section{Debitage}

A total of 135 debitage was recovered during the 19992000 survey and 2000 testing efforts at 41LR208. Of these items 32 are from Maxey II and 103 are from Maxey III. Of this total, 46 are chert, two are novaculite, one is silicified wood, and 86 are quartzite. Among the assemblage, two quartzite flakes are heat-treated. This pattern suggests that, minimally, thermal alteration of stone raw materials to improve workability may have been of low importance at this site.

Chert and quartzite clearly dominate the debitage total. Of the 46 chert flakes, 30 are decorticate, 11 have $1-50 \%$ cortex, three have $51-99 \%$ cortex, and two have $100 \%$ cortex. The mean thickness to length ratio for the chert debitage is 0.17 . Of the 86 quartzite flakes, 40 are decorticate, 29 have $1-50 \%$ cortex, 11 have $51-99 \%$ cortex, and six have $100 \%$ cortex. The mean thickness to length ratio for the quartzite debitage is 0.19 . These patterns indicate that the primary lithic 


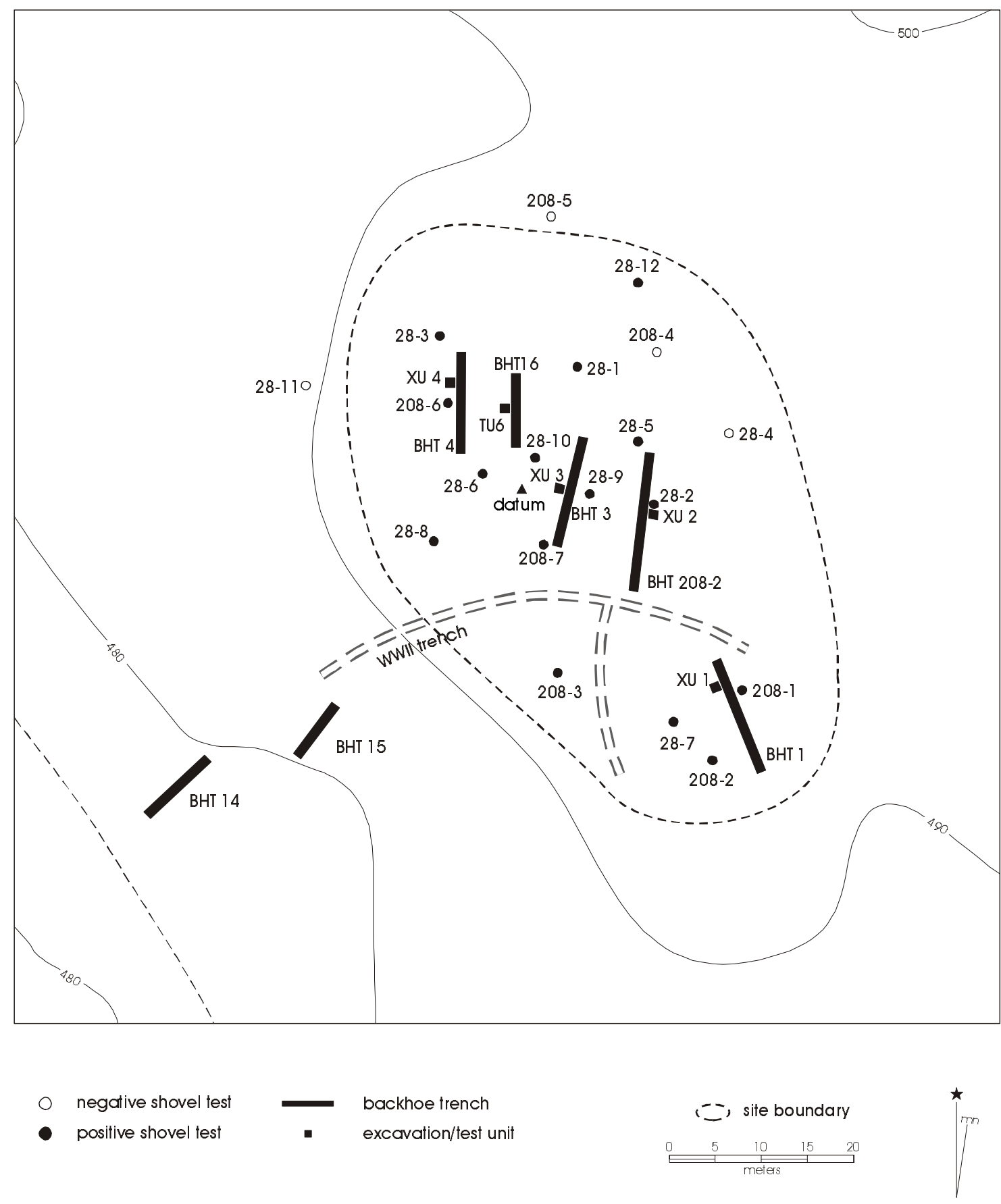

Figure 38. Site map - 41LR208. 
activity, as reflected by the recovered debitage, was middle stage reduction and tool production.

An itemization of the flake types among the chert debitage presents three biface manufacture flakes, two biface rejuvenation flakes, two biface thinning flakes, 17 core preparation flakes, five platform preparation flakes, and 17 indeterminate flakes. Among the quartzite, there are four biface manufacture flakes, two biface thinning flakes, 37 core preparation flakes, 22 platform preparation flakes, and 21 indeterminate flakes. These comparisons further indicate tool manufacture as the primary activity represented in the lithic assemblage.

Debitage was encountered from 0-60 cm bs, with the greatest density (44\%) of flakes recovered within levels one and two, or 0-20 cm bs. Debitage density gradually tapers off in levels three through six (20-60 $\mathrm{cm}$ bs), with an abrupt termination below $60 \mathrm{~cm}$ bs. Based upon the vertical distribution of this assemblage, a cultural zone is indicated from $0-40 \mathrm{~cm}$ bs.

Artifacts produced from non-local raw materials recovered from this site include novaculite and gray cherts. Novaculite is generally associated with the Ouchita Mountains in Eastern Oklahoma and Western Arkansas. The gray cherts are typically associated with the Georgetown cherts of central Texas.

\section{LR212}

\section{Description}

Site 41LR212 is located in the southwestern portion of the facility approximately $80 \mathrm{~m}$ west of an unnamed tributary to Sanders Creek (see Figure 10 in supplement). The site is situated atop an upland landform of Whakana-Porum series loams at 480-490 ft AMSL. The vegetation community consists of the Schizachyrium scoparium Herbaceous class, providing roughly 5\% ground surface visibility.

One backhoe trench, one excavation unit, and 21 shovel tests were excavated to define the site boundary (Figure 39). Based on these data, the site measures approximately $15 \times 20-\mathrm{m}$ and covers an area of roughly 280 square meters. A total of ten shovel tests were placed within the site. Eight (80\%) of these ten shovel tests were positive. Cultural material extends from $0-60 \mathrm{~cm}$ bs, with the greatest density $(51 \%)$ of provenienced artifacts encountered within levels one and two, or $0-20 \mathrm{~cm}$ bs.

\section{Discussion}

This site occupies a small, circular rise within an open savanna of little bluestem. The mound has been impacted by military activity via excavation of a foxhole within the central portion. Additionally, two hardwood trees are situated adjacent to the foxhole, contributing abundant root disturbance throughout the mound. Cultural material was encountered atop the ground surface within the backdirt of the foxhole, indicating that the excavation disturbed an intact portion of the cultural deposits. The survey phase positive shovel tests were limited to those placed atop the mound; shovel tests excavated in the surrounding savanna all produced negative results. Excavation of the single excavation unit produced a single, untypeable arrow point and the proximal portion of a Gary dart point. Three native ceramic sherds were recovered during the survey phase, suggesting that the small mound contains multiple components of occupation spanning the Late Archaic through the Late Prehistoric. 


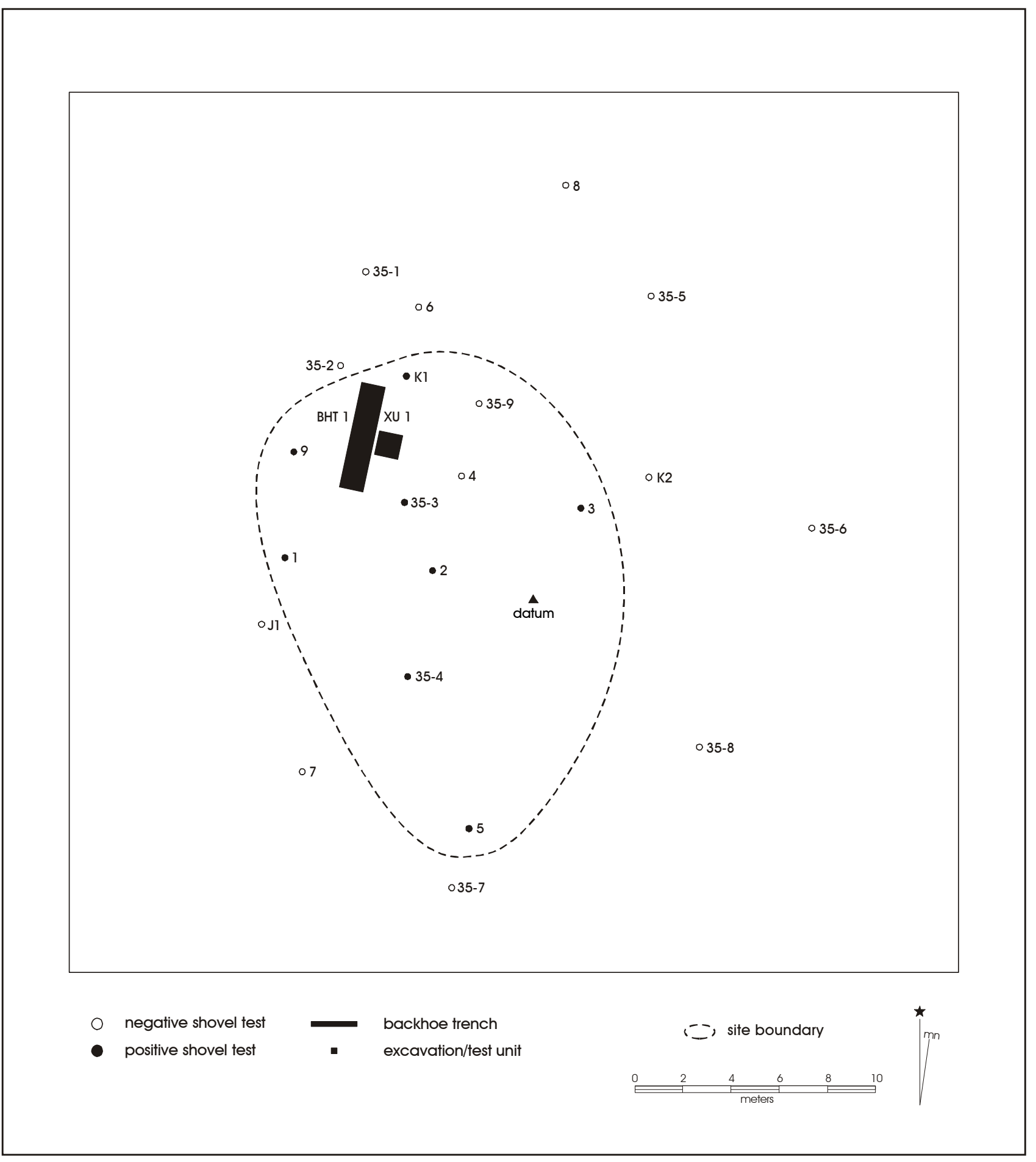

Figure 39. Site map - 41LR212. 


\section{Cultural Material}

\section{Native Ceramics}

No ceramics were recovered during the 2001 investigations.

\section{Investigations}

The ceramics from the site are a plain body sherd from ST K-1 and a plain rim sherd from the surface at ST 35-3. Both are tempered with grog and have thick body walls $(8.7-9.4 \mathrm{~mm})$. The rim is direct with a rounded lip, and is from a vessel that was fired in a reducing environment and cooled in a high oxygen environment. The plain body sherd is from a vessel that was oxidized during firing.

\section{Lithics}

\section{Tools}

Eight specimens comprise the tool assemblage recovered from 41LR212. Included is a Gary dart point fragment, an arrow point preform, a quarry blank, three biface fragments, one edge-modified flake, and one core. The Gary dart point proximal fragment (see Figure 25, LR212b) has a contracting stem with a rounded base and a medial break. It is manufactured of local tan chert and is probably from a relatively small cobble. Indication of near-cortical material (typically red for this local tan chert) exists along the proximal barb tips and at the base. The untypeable, unfinished arrow point preform (see Figure 25, LR212a) has a single corner-notch removed and is manufactured of white chert. The quarry blank is heattreated and is manufactured from a medium-grained gray quartzite. The three biface fragments are all distal fragments and manufacture failures of quartzite. The edge-modified flake is an expedient scraper manufactured of gray chert. The large core is manufactured from tan chert and retains $75 \%$ cortex.

\section{Debitage}

A total of 30 debitage was recovered during the 19992000 survey and 2000 testing efforts at 41LR212. Of this total, 18 are chert, 11 are quartzite, and one is quartz. Among the assemblage, one chert flake is heattreated. This pattern suggests that, minimally, thermal alteration of stone raw materials to improve workability may have been of low importance at this site.
As at all of the sites in this study, chert and quartzite clearly dominate the debitage total. Of the 18 chert flakes, 14 are decorticate, two have $1-50 \%$ cortex, one has $51-99 \%$ cortex, and one has $100 \%$ cortex. The mean thickness to length ratio for the chert debitage is 0.21 . Of the 11 quartzite flakes, four are decorticate, five have $1-50 \%$ cortex, one has $51-99 \%$ cortex, and one has $100 \%$ cortex. The mean thickness to length ratio for the quartzite debitage is 0.20 . These patterns indicate that the primary lithic activity, as reflected by the recovered debitage, was early to middle stage reduction and tool production.

An itemization of the flake types among the chert debitage presents six core preparation flakes, four platform preparation flakes, and eight indeterminate flakes. Among the quartzite, there is one biface manufacture flake, seven core preparation flakes, and three platform preparation flakes. These comparisons further indicate tool manufacture as the primary activity represented in the lithic assemblage.

Debitage was encountered from $0-60 \mathrm{~cm} \mathrm{bs}$, with the identical densities $(37 \%)$ of flakes recovered within levels one and two (0-20 cm bs) and levels three and four (20-40 cm bs). Debitage density abruptly terminates below $60 \mathrm{~cm}$ bs. Based upon the vertical distribution of this assemblage, a cultural zone is indicated at $0-40 \mathrm{~cm}$ bs.

Artifacts produced from non-local raw materials recovered from this site include quartz and gray cherts. Quartz is indicative of an Ouchita Mountain source and may be encountered along the Red River. The gray cherts are typically associated with the Georgetown cherts of central Texas. 


\section{LR260}

\section{Description}

Site 41LR260 is located in the northwestern portion of the facility occupying an interfluve of two unnamed tributaries of Sanders Creek (see Figure 10 in supplement). The site is situated atop an upland ridge landform of Woodtell series loams at 490-500 ft AMSL. The vegetation community consists of the Quercus stellata-Quercus marilandica-(Carya texana) Woodland class, providing roughly $15 \%$ ground surface visibility.

Seven backhoe trenches, three excavation units, and 33 shovel tests were excavated to define the site (Figure 40). Based on these data, the site measures approximately $90 \times 125-\mathrm{m}$, and covers an area of about 8,960 square meters. Twenty-five shovel tests were excavated within the current boundary. Of these, 16 (64\%) shovel tests were positive. Cultural material extends from $0-100 \mathrm{~cm}$ bs, with the greatest density (29\%) of provenienced artifacts encountered within levels three and four, or $20-40 \mathrm{~cm}$ bs.

\section{Discussion}

The site occurs along the northern facility boundary with COE property to the north; possibly as much as $30 \%$ of the site extends onto COE lands. Uncharacteristically deep ( $>3 \mathrm{~m}$ ) sands comprise the northern two-thirds of the site, with an upward slope to approximately $40 \mathrm{~cm}$ bs in the southern portion of the site. A steep ravine delimits the western boundary of the site, with a terraced slope and associated perennial stream forming the eastern boundary. A range of prehistoric material was recovered; however, bioturbation within each excavation unit precluded the definition of a living surface.

Sediment susceptibility samples were collected from XU 2, from 0 to $80 \mathrm{~cm}$ bs, at $10-\mathrm{cm}$ intervals. As detailed in Appendix B, a smaller peak is present in these values at 20 to $30 \mathrm{~cm}$ bs. While the peak is not extreme, correlation of this peak with an increase in sitelevel artifacts between 20 and $40 \mathrm{~cm}$ bs, suggests that a buried surface may be present at 41LR260.

\section{Cultural Material}

\section{Native Ceramics}

\section{Investigations}

The single prehistoric ceramic sherd (ST 84-1, 40-60 $\mathrm{cm} \mathrm{bs}$ ) is a plain body sherd (7.7 $\mathrm{mm}$ in thickness) from a vessel that has been tempered with grog and crushed hematite, and that was fired in a reducing environment.

\section{Investigations}

There are 32 sherds, four sherdlets, and one piece of fired clay in the 41LR260 ceramic assemblage. Most of the ceramics are from the southwestern part of the site in Unit 2 and ST 260-4, and this is about $20 \mathrm{~m}$ south of the single shovel test (ST 84-1) that had ceramics in the archaeological survey investigations (Lyle et al. 2001:Figure C-21).

All the sherds, including two plain rims, six base sherds, and 24 body sherds, from 41LR260 have grog temper. Six (18.8 percent) also have burned bone temper inclusions, another ( 3 percent) has crushed rock or grit temper, and five others (15.6 percent) have a sandy paste in addition to the grog tempering. Four of the body sherds, one of the plain rims, and the one decorated sherd have been smoothed on interior and/ or exterior vessel surfaces, and another has exterior burnishing.

More than 66 percent of the sherds are from vessels that were fired in a reducing environment, and vessel wall thicknesses are $6.39 \pm 0.91 \mathrm{~mm}$ (grog-tempered), $6.53 \pm 0.96 \mathrm{~mm}$ (grog and sandy paste), and $6.65 \pm$ $0.55 \mathrm{~mm}$ (grog-bone-tempered). The plain rims are direct, with rounded lips, and $6.05 \pm 0.05 \mathrm{~mm}$ thick. The six flat base sherds are from a minimum of four different vessels; they are $10.8 \pm 0.9 \mathrm{~mm}$ thick.

The single decorated sherd (XU 2, 20-30 cm bs) is a grog-tempered body sherd with at least two parallel engraved lines. The sherd is also smoothed on interior and exterior surfaces, and probably is from a bowl or carinated bowl. The evidence for coil marks further suggests that the engraved lines are probably horizontal lines encircling the vessel. Such decorations may be most common in Early Caddoan contexts in the middle Red River valley of Northeast Texas. 


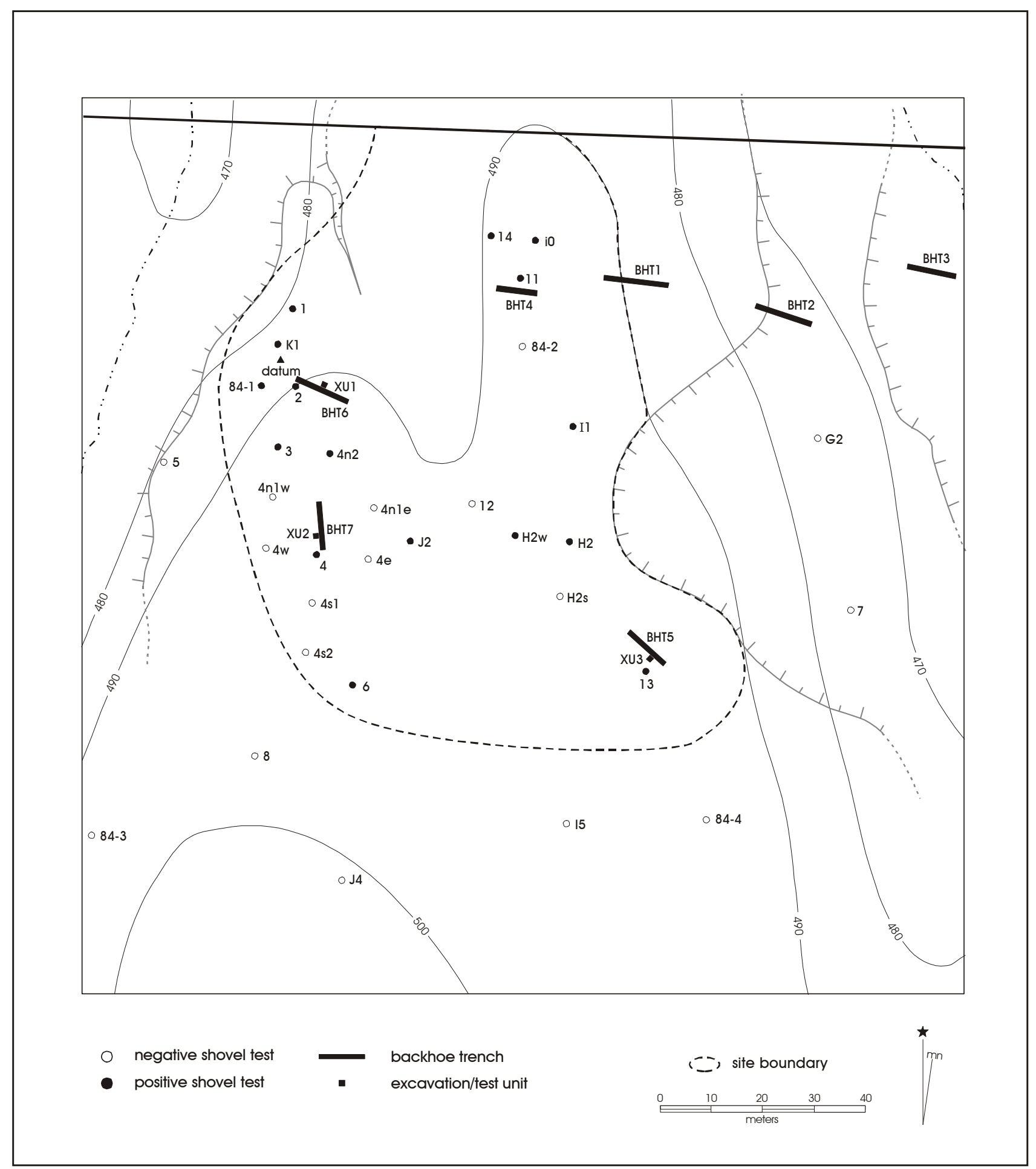

Figure 40. Site map - 41LR260. 
The one piece of fired clay in XU 2 (10-20 cm bs) weighs $5.1 \mathrm{~g}$. It probably represents evidence for an episode of burning at 41LR260, either from a claylined hearth or the mud plastering from a structure.

\section{Lithics}

\section{Tools}

Twelve stone tools were recovered from 41LR260. The assemblage consists of a Wells dart point, a Gary dart point, a Perdiz arrow point, four biface fragments, a hammerstone, and four cores. The Wells dart point (see Figure 25, LR260a) has a parallel to slightly contracting stem, barbless, has weak shoulders, and has extreme alternate beveling. It is manufactured from a green and tan mottled quartzite. The Gary dart point (see Figure 25, LR260b) has a contracting stem with a rounded base and a barb tip break, suggestive of a use break. It is manufactured from a fine-grained gray quartzite. The Perdiz arrow point has a distal break, is heat-treated, and is manufactured from a gray quartzite. The four biface fragments all have some cortex and are early reduction stage specimens. The hammerstone exhibits moderate pecking along one face. It is manufactured from a coarse-grained green quartzite. All four of the cores are manufactured from a fine to medium-grained gray quartzite.

\section{Debitage}

A total of 163 debitage was recovered during the 19992000 survey and 2000 testing efforts at 41LR260. Of these items 58 are from Maxey II and 105 are from Maxey III. Of this total, 83 are chert, 72 are quartzite, one is quartz, and seven are silicified sandstone. Among the assemblage, two chert flakes and five quartzite flakes are heat-treated. This pattern suggests that, minimally, thermal alteration of stone raw materials to improve workability may have been of low importance at this site.

As at all of the sites in this study, chert and quartzite clearly dominate the debitage total. Of the 83 chert flakes, 48 are decorticate, 24 have $1-50 \%$ cortex, six have $51-99 \%$ cortex, and five have $100 \%$ cortex. The mean thickness to length ratio for the chert debitage is 0.16 . Of the 72 quartzite flakes, 30 are decorticate, 29 have $1-50 \%$ cortex, eight have $51-99 \%$ cortex, and five have $100 \%$ cortex. The mean thickness to length ratio for the quartzite debitage is 0.20 . These patterns indicate that the primary lithic activity, as reflected by the recovered debitage, was tool manufacture.

An itemization of the flake types among the chert debitage presents one biface rejuvenation flake, three biface thinning flakes, one core flake, one uniface flake, 24 core preparation flakes, 14 platform preparation flakes, and 39 indeterminate flakes. Among the quartzite, there are one angular debitage flake, one biface thinning flake, 27 core preparation flakes, 18 platform preparation flakes, and 25 indeterminate flakes. These comparisons further indicate tool manufacture as the primary activity represented in the lithic assemblage.

Debitage was encountered from $0-100 \mathrm{~cm}$ bs, with the greatest density $(30 \%)$ of flakes recovered within levels three and four, or $20-40 \mathrm{~cm}$ bs. Debitage density gradually tapers off in levels five through ten (40$100 \mathrm{~cm} \mathrm{bs}$ ), with an abrupt termination below $100 \mathrm{~cm}$ bs. Based upon the vertical distribution of this assemblage, a cultural zone is indicated from $20-40 \mathrm{~cm}$ bs.

Artifacts produced from non-local raw materials recovered from this site include quartz and gray cherts. Quartz is indicative of an Ouchita Mountain source and may be encountered along the Red River. The gray cherts are typically associated with the Georgetown cherts of central Texas. 


\section{LR266}

\section{Description}

Site 41LR266 is located in the northwestern portion of the facility along the right downstream bankline of an unnamed tributary of Sanders Creek (see Figure 10 in supplement). The site is situated atop a toe slope landform of Whakana series fine sandy loams at 490 $500 \mathrm{ft}$ AMSL. The vegetation community consists of the Quercus stellata-Quercus marilandica-(Carya texana) Woodland class, providing roughly $25 \%$ ground surface visibility.

Two backhoe trenches, two excavation units, and 14 shovel tests were excavated to define the site boundary (Figure 41). Based on these data, the site measures approximately $70 \times 50-\mathrm{m}$ and covers an area of 2,560 square meters. Within the site, a total of six shovel tests were excavated. Four (67\%) of these six shovel tests were positive. Cultural material extends from $0-100 \mathrm{~cm}$ bs, with the greatest density $(37 \%)$ of provenienced artifacts encountered within levels five and six, or $40-60 \mathrm{~cm}$ bs.

\section{Discussion}

This site occurs at a probable point bar or gravel bar at the right downstream bankline of an unnamed tributary of Sanders Creek. In the southern portion of the site, small to moderate gravels, fist-sized cobbles of quartzites, and sands are present from ground surface to approximately $3 \mathrm{~m} \mathrm{bs}$, at which point the ground water table was encountered in backhoe trench one. Further upslope and within backhoe trench two, basal clays are encountered at roughly $40 \mathrm{~cm}$ bs. Very little evidence for long-term occupation was encountered; this site may have served as a raw material source for surrounding sites such as 41LR186, 41LR187, and 41LR260.

\section{Cultural Material}

\section{Native Ceramics}

No ceramics were recovered during either phase of investigations.

\section{Lithics}

\section{Tools}

No stone tools were recovered during either phase of investigations.

\section{Debitage}

A total of nine debitage was recovered during the 1999-2000 survey and 2000 testing efforts at 41LR266. Of this total, one is chert, one is novaculite, one is silicified wood, and six are quartzite. Among the assemblage, one silicified wood flake is heat-treated. This pattern suggests that, minimally, thermal alteration of stone raw materials to improve workability may have been of low importance at this site.

The single chert flake is decorticate, with a thickness to length ratio of 0.08 . Of the six quartzite flakes, four are decorticate, one has 1-50\% cortex, and one has $100 \%$ cortex. The mean thickness to length ratio for the quartzite debitage is 0.18 . These patterns suggest that the primary lithic activities, as reflected by the recovered debitage, were middle to late stage reduction and tool production/rejuvenation.

An itemization of the flake types among the quartzite debitage presents three core preparation flakes and three indeterminate flakes. The single chert flake is classified as an indeterminate flake. These comparisons further suggest tool manufacture as the primary activity represented in the lithic assemblage.

Debitage was encountered from $0-100 \mathrm{~cm}$ bs, with the greatest density (33\%) of flakes recovered within levels five and six, or $40-60 \mathrm{~cm}$ bs. Debitage density drops considerably below $60 \mathrm{~cm}$ bs, with only one flake recovered from $60-80 \mathrm{~cm}$ bs and one flake from $80-100 \mathrm{~cm}$ bs. Based upon the vertical distribution of this assemblage, no definable stratification of discrete cultural deposits is evident.

Artifacts produced from non-local raw materials recovered from this site include novaculite. Novaculite is generally associated with the Ouchita Mountains in Eastern Oklahoma and Western Arkansas. 

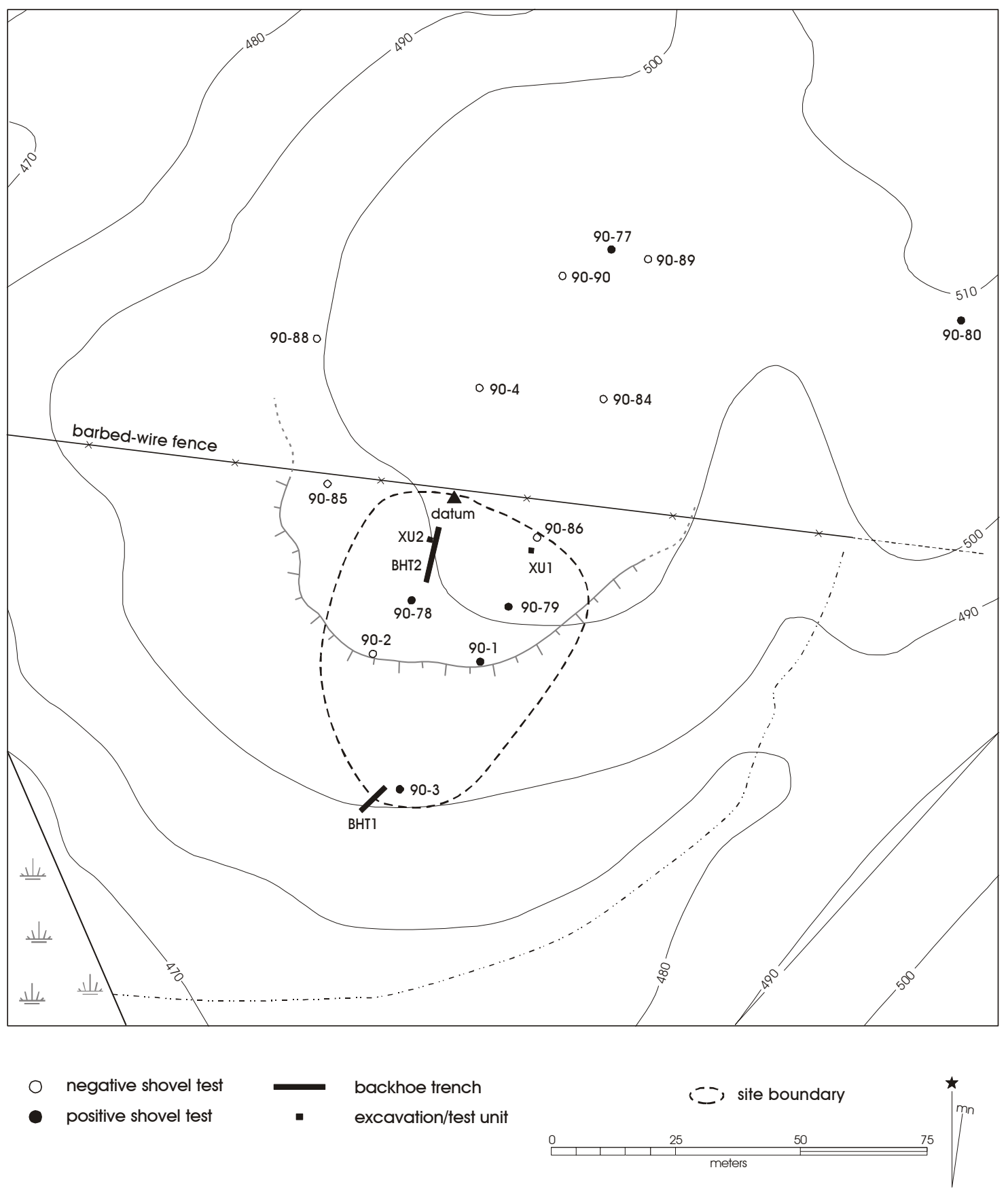

Figure 41. Site map - 41LR266. 


\section{LR268}

\section{Description}

Site 41LR268 is located in the west-central portion of the facility along the right downstream bankline of an unnamed tributary of Sanders Creek (see Figure 10 in supplement). The site is situated atop an upland landform of Annona series loams at 480-510 ft AMSL. The vegetation community consists of the Quercus nigraUlmus americana Woodland class, providing roughly $40 \%$ ground surface visibility.

Three backhoe trenches, three excavation units, and 12 shovel tests were excavated to define the site (Figure 42). Based on these data, the site measures approximately $120 \times 80-\mathrm{m}$ and covers an area of 5,580 square meters. Eleven shovel tests were excavated within the site. Nine $(82 \%)$ of these 11 shovel tests were positive. Cultural material extends from 0-80 $\mathrm{cm}$ bs, with the greatest density (39\%) of provenienced artifacts encountered within levels three and four, or $20-40 \mathrm{~cm}$ bs.

\section{Discussion}

The site is situated at the southern termini of twin finger ridges, with natural boundaries provided to the west, south, and east by steep ravines of an unnamed, intermittent tributary to Sanders Creek. The twin ridges were probably a former single upland ridge that has since been subjected to erosional forces in the form of a deep, narrow erosional crevasse. The lack of native ceramics and the presence of burned rock, debitage, and a single dart point suggest an Archaic open campsite.

Sediment susceptibility samples were collected from XU 3, from 0 to $50 \mathrm{~cm} \mathrm{bs,} \mathrm{at} 10-\mathrm{cm}$ intervals. As detailed in Appendix B, no significant peaks were noted in the values with the possible exception of a slight increase at 40 to $50 \mathrm{~cm}$ bs. This lack of any significant spike suggests that, at least in the single area tested, no buried surfaces are present.

\section{Cultural Material}

\section{Native Ceramics}

No ceramics were recovered during either phase of investigations.

\section{Lithics}

\section{Tools}

Seven stone tools were recovered from 41LR268. The assemblage includes a Gary dart point, an indeterminate biface, an indeterminate biface fragment, and four cores. The Gary dart point has a contracting stem and a rounded base. It is manufactured from a coarsegrained gray quartzite. The indeterminate biface is an early reduction specimen of medium-grained gray quartzite. The biface fragment is heat-treated and is manufactured from a medium-grained gray quartzite. It has a broken but pointed base reminiscent of a Perdiz point preform. Three of the four cores are mediumgrained gray quartzites, the fourth is a local finegrained chert specimen.

\section{Debitage}

A total of 137 debitage was recovered during the 19992000 survey and 2000 testing efforts at 41LR268. Of these items -five are from Maxey II and 132 are from Maxey III. Of this total, 32 are chert, one is silicified wood, 101 are quartzite, and three are silicified sandstone. Among the assemblage, five quartzite flakes are heat-treated. This site pattern suggests that, minimally, thermal alteration of stone raw materials to improve workability may have been of low importance here.

As at all of the sites in this study, chert and quartzite clearly dominate the debitage total. Of the 32 chert flakes, 22 are decorticate, five have $1-50 \%$ cortex, four have $51-99 \%$ cortex, and one has $100 \%$ cortex. The mean thickness to length ratio for the chert debitage is 0.18 . Of the 101 quartzite flakes, 66 are decorticate, 21 have $1-50 \%$ cortex, seven have 51$99 \%$ cortex, and seven have $100 \%$ cortex. The mean thickness to length ratio for the quartzite debitage is 0.18 . These patterns are suggestive of middle stage reduction and tool production. 

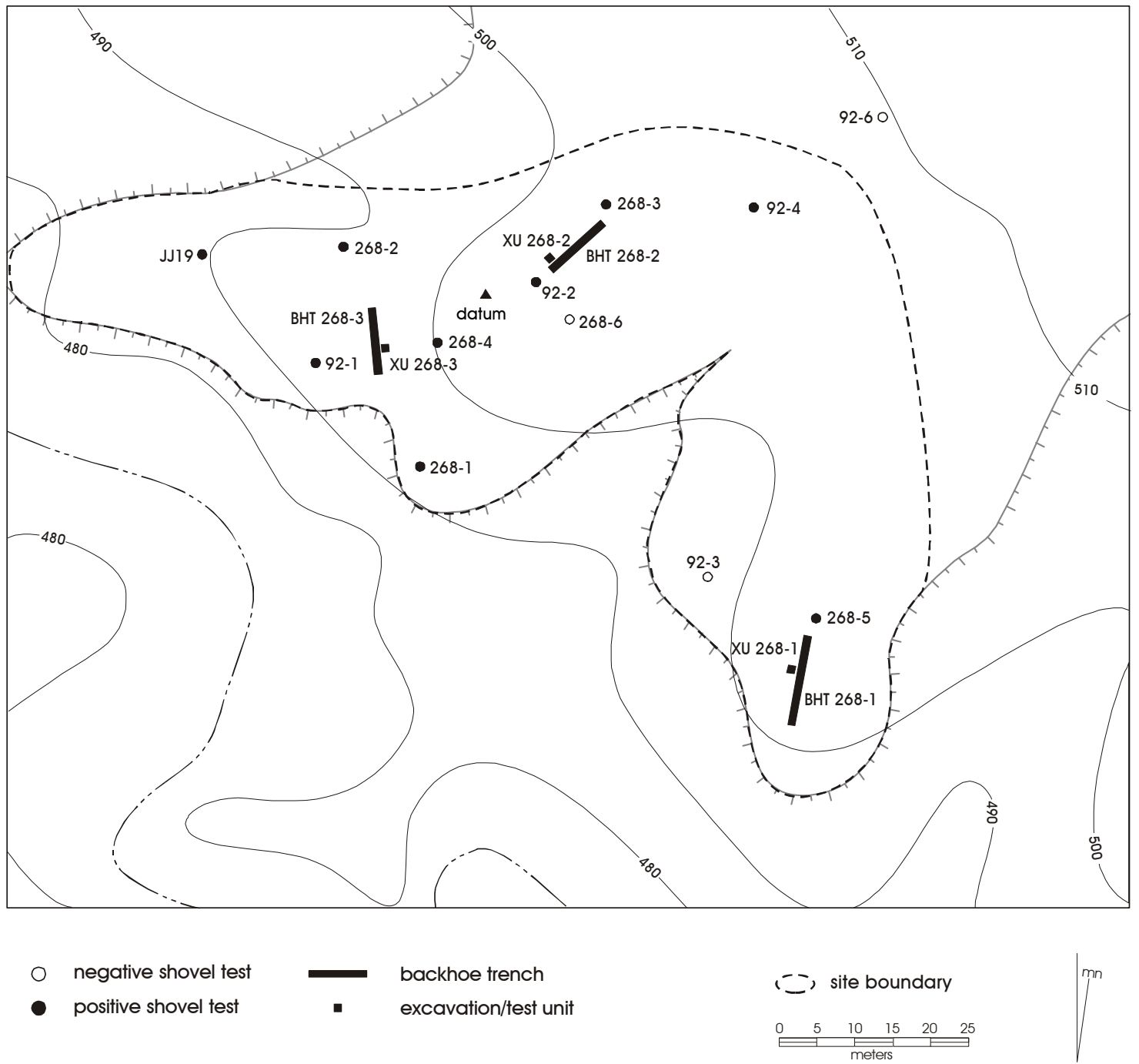

Figure 42. Site map - 41LR268.

An itemization of the flake types among the chert debitage presents one biface rejuvenation flake, two biface thinning flakes, nine core preparation flakes, ten platform preparation flakes, and ten indeterminate flakes. Among the quartzite, there are one angular debitage, three biface manufacture flakes, three biface thinning flakes, 29 core preparation flakes, 28 platform preparation flakes, and 37 indeterminate flakes. These comparisons indicate tool manufacture as the primary activity represented in the lithic assemblage.
Debitage was encountered from $0-80 \mathrm{~cm}$ bs, with the greatest density $(41 \%)$ of flakes recovered within levels three and four, or $20-40 \mathrm{~cm}$ bs. Debitage density drops considerably below $60 \mathrm{~cm}$ bs, with only one flake recovered from $60-80 \mathrm{~cm}$ bs. Based upon the vertical distribution of this assemblage, a cultural zone is indicated from $20-40 \mathrm{~cm}$ bs.

Artifacts produced from non-local raw materials recovered from this site include green cherts. The green cherts are typically related to Oklahoma and may be encountered in Red River gravels. 


\section{LR285}

\section{Description}

Site 41LR285 is located in the southwestern portion of the facility along the right descending bankline of an unnamed tributary of Visor Creek (see Figure 10 in supplement). The site is situated atop an upland landform of Whakana series fine sandy loams at 500 $510 \mathrm{ft}$ AMSL. The vegetation community consists of the Quercus nigra-Ulmus americana Woodland class, providing roughly $10 \%$ ground surface visibility.

Three backhoe trenches, two excavation units, and 25 shovel tests were excavated to define the site (Figure 43). Based on these data, the site measures approximately 75 x 30-m, and covers an area of about 2,760 square meters. A total of 20 shovel tests were excavated within the site. Twelve $(60 \%)$ of these shovel tests were positive. Cultural material extends from $0-70 \mathrm{~cm}$ bs, with the greatest density (50\%) of provenienced artifacts encountered within levels one and two, or 0-20 cm bs.

\section{Discussion}

41LR285 was originally mapped as the westernmost extension of 41LR158, the upland gravel deposit site. However, subsequent shovel tests excavations have delimited this small area as a discrete, prehistoric open campsite located along an intermittent stream. Remnants of the prehistoric component include lithic debitage and burned rock fragments; no native ceramics were encountered during excavations. Additionally, evidence of historic activity and possible occupation in the area include a discontinuous line of fence posts with barbed wire still adhering via fence staples. Carpet grass, lilacs, and flowering dogwood along the stream further suggest historic occupation. No evidence of structures or historic artifacts was noted in any of the mechanical or manual excavations.

\section{Cultural Material}

\section{Native Ceramics}

No ceramics were recovered during either phase of investigations.

\section{Lithics}

\section{Tools}

Three cores comprise the assemblage of stone tools recovered from 41LR285. All of the cores are manufactured from quartzite and exhibit $50-90 \%$ cortex.

\section{Debitage}

A total of 22 debitage was recovered during the 1998 survey and 2000 testing efforts at 41LR285. Of this total, 11 are chert and 11 are quartzite. Among the assemblage, one chert flake is heat-treated. This pattern suggests that, minimally, thermal alteration of stone raw materials to improve workability may have been of low importance at this site.

As at all of the sites in this study, chert and quartzite clearly dominate the debitage total. Of the 11 chert flakes, five are decorticate and six have $1-50 \%$ cortex. The mean thickness to length ratio for the chert debitage is 0.14 , which is suggestive of late stage reduction and tool resharpening. Of the 11 quartzite flakes, three are decorticate, one has $1-50 \%$ cortex, four have $51-99 \%$ cortex, and three have $100 \%$ cortex. The mean thickness to length ratio for the quartzite debitage is 0.27 . The pattern for the quartzite debitage is indicative of early stage reduction and procurement, possibly from nearby 41LR158.

An itemization of the flake types among the chert debitage presents one biface manufacture flake, one biface thinning flake, five core preparation flakes, one platform preparation flake, and three indeterminate flakes. Among the quartzite, there are eight core preparation flakes, one platform preparation flake, and two indeterminate flakes. These comparisons further suggest tool manufacture as the primary activity represented in the lithic assemblage.

Debitage was encountered from $0-80 \mathrm{~cm}$ bs, with the greatest density (53\%) of flakes recovered within levels one and two, or 0-20 cm bs. Debitage density drops considerably below $40 \mathrm{~cm}$ bs, with only one flake recovered from $40-60 \mathrm{~cm}$ bs and one flake recovered from $60-80 \mathrm{~cm}$ bs. Based upon the vertical distribution of this assemblage, a cultural zone is indicated from 0-20 cm bs. 


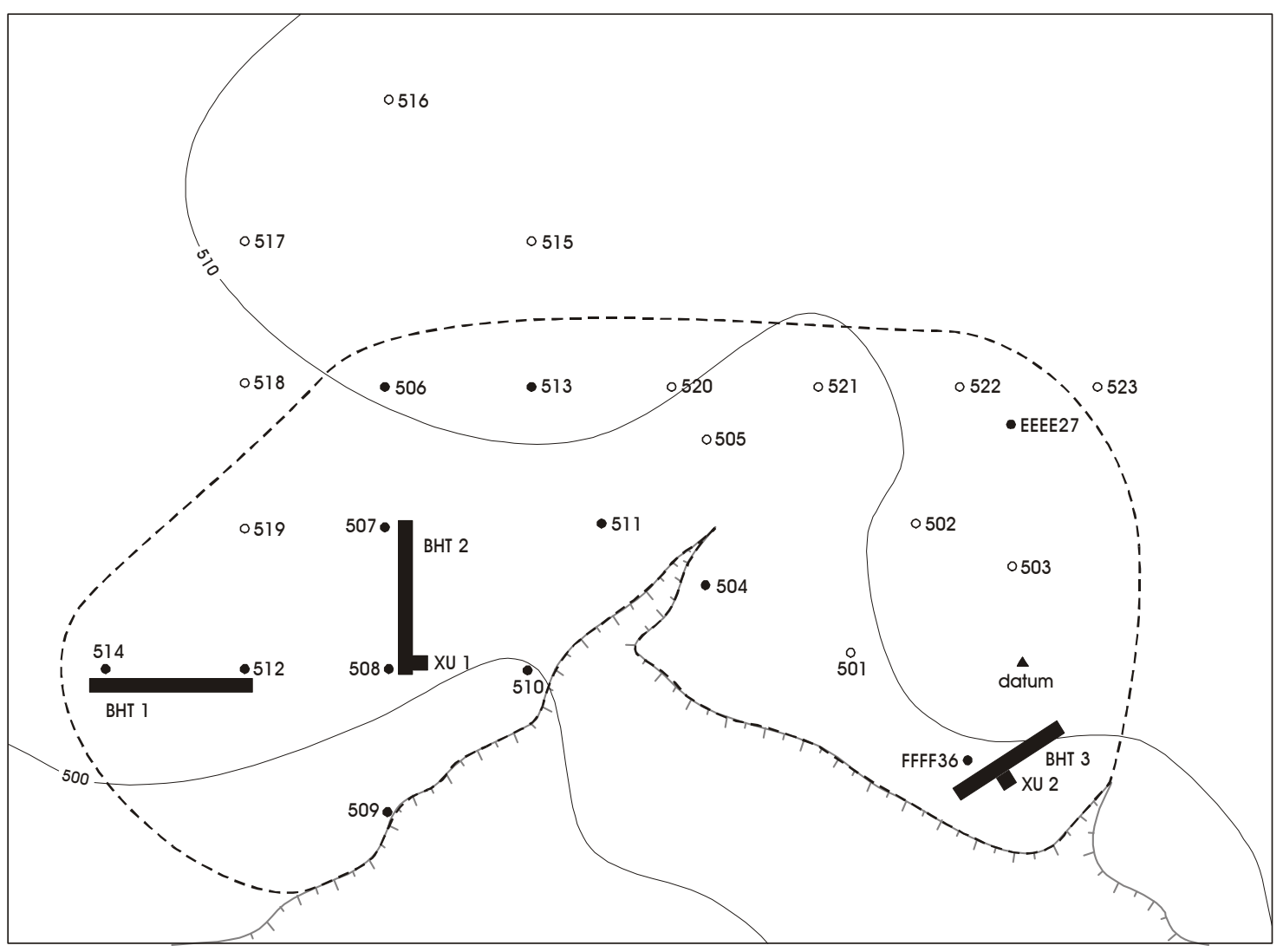

negative shovel test backhoe trench

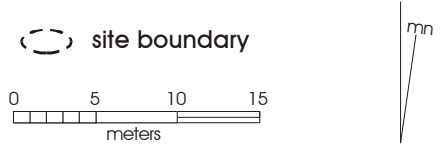

Figure 43. Site map - 41LR285. 


\section{LR286}

\section{Description}

Site 41LR286 is located in the west-central portion of the facility along the right descending bankline of an unnamed tributary of Sanders Creek (see Figure 10 in supplement). The site is situated atop an upland landform of Whakana series fine sandy loams at 490-500 $\mathrm{ft}$ AMSL. The vegetation community consists of the Quercus nigra-Ulmus americana Woodland and Schizachyrium scoparium Herbaceous classes, providing roughly $10 \%$ ground surface visibility.

Three backhoe trenches, three excavation units, and 27 shovel tests were placed to define the site (Figure 44). Based on these data, the site measures approximately 180 x 90-m and covers an area of about 9,235 square meters. Within the site, eight shovel tests were excavated. Six (75\%) of these eight shovel tests were positive. Cultural material extends from $0-50 \mathrm{~cm}$ bs, with the greatest density (58\%) of provenienced artifacts within levels one and two, or $0-20 \mathrm{~cm}$ bs.

\section{Discussion}

During the 1999 survey phase, 41LR286 was originally mapped as a southern extension of 41LR168. However, additional shovel test excavations in concert with testing efforts conducted during September 2000 indicate that the previously delimited site bounds actually encompassed two separate sites. Specifically, the presence of an approximately $200 \mathrm{~m}$ corridor of negative shovel tests separating the two positive concentrations warrants separate site designations/trinomials. These subsequent shovel tests excavations have delimited this southern area as a discrete, prehistoric lithic scatter located along an upland drainage. Remnants of the prehistoric component include lithic debitage and burned rock fragments; no native ceramics were encountered during excavations.

Sediment susceptibility samples were collected from excavation unit 1 , from 0 to $50 \mathrm{~cm}$ bs, at $10-\mathrm{cm}$ intervals. As detailed in Appendix B, significant peaks are present at 10 to $20 \mathrm{~cm} \mathrm{bs}$, and at 40 to $50 \mathrm{~cm}$ bs. The
10 to $20 \mathrm{~cm}$ peak correlates with the higher artifact content reflected for the upper $20 \mathrm{~cm}$ at the site. The high value of the 40 to $50 \mathrm{~cm}$ peak may be related to small quantities of ferrous material, though the value is within the range present for sediments that have high organic and ash deposits.

\section{Cultural Material}

\section{Native Ceramics}

No ceramics were recovered during either phase of investigations.

\section{Lithics}

\section{Tools}

A Gary dart point and two distal biface fragments comprise the tool assemblage recovered from 41LR286. The Gary dart point has a contracting stem and a rounded base. It is heat-treated and is manufactured from a coarse-grained red quartzite. One of the biface fragments (Cat. No. 1-1) is an early stage reduction specimen manufactured from coarse-grained gray quartzite. The second distal fragment has been heattreated and exhibits alternate beveling. It is manufactured from a fine-grained gray quartzite.

\section{Debitage}

A total of nine debitage was recovered during the 2000 testing efforts at 41LR286. Of this total, two are chert and seven are quartzite. Among the assemblage, none of the flakes are heat-treated. This pattern suggests that, minimally, thermal alteration of stone raw materials to improve workability may not have been implemented at this site.

As at all of the sites in this study, chert and quartzite clearly dominate the debitage total. Of the two chert flakes, one is decorticate and one has $1-50 \%$ cortex. The mean thickness to length ratio for the chert debitage is 0.13 . This pattern suggests late stage reduction and tool resharpening /rejuvenation. Of the seven quartzite flakes, five are decorticate, one has $1-50 \%$ cortex, and one has $100 \%$ cortex. The mean thickness to length ratio for the quartzite debitage is 0.19 . This pattern is suggestive of middle stage reduction and tool production. 


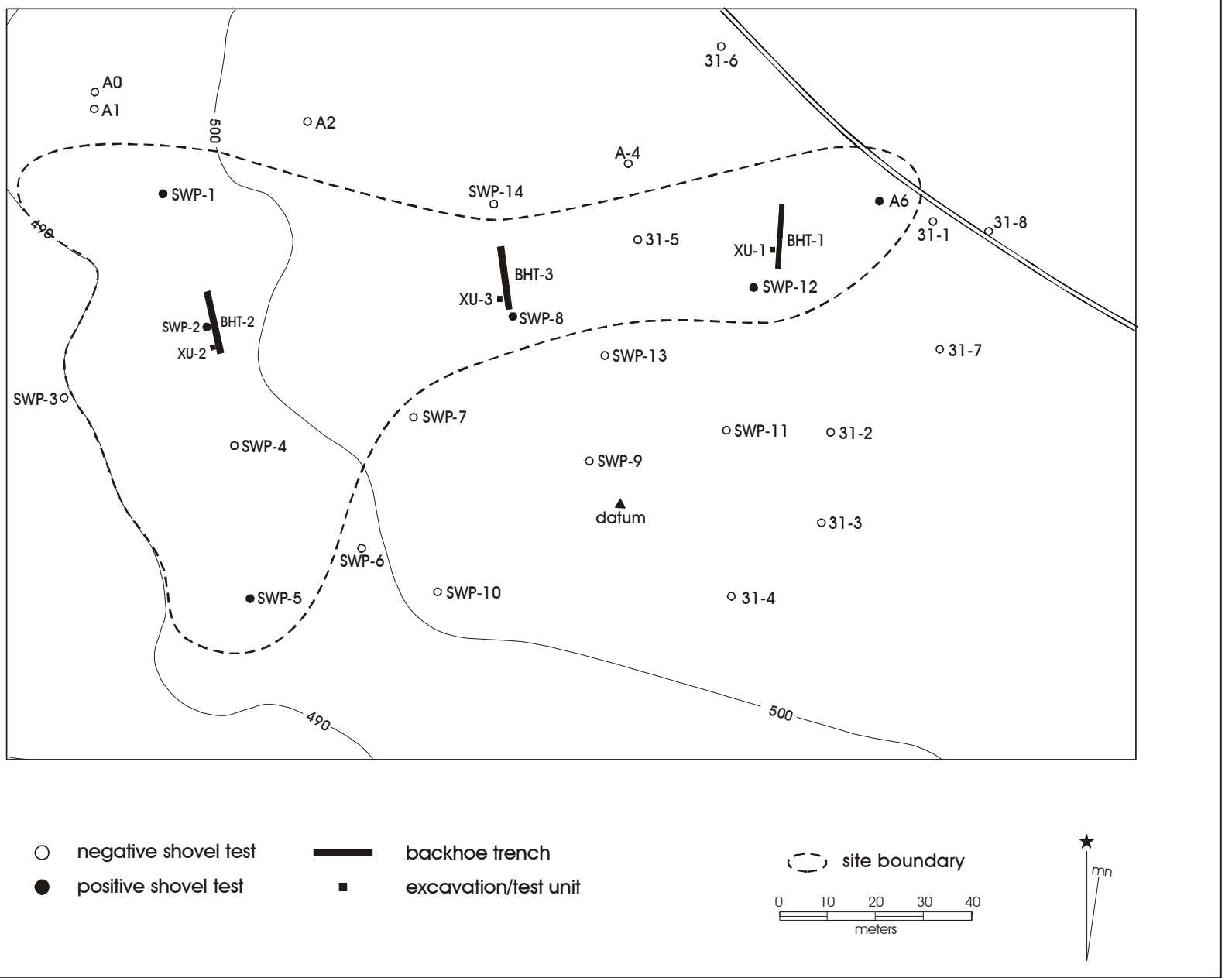

Figure 44. Site map - 41LR286.

An itemization of the flake types among the chert debitage presents one core preparation flake and one platform preparation flake. Among the quartzite, there are one biface manufacture flake, three core preparation flakes, one platform preparation flake, and two indeterminate flakes. These comparisons further suggest tool manufacture as the primary activity represented in the lithic assemblage.
Debitage was encountered from $0-40 \mathrm{~cm}$ bs, with the greatest density $(56 \%)$ of flakes recovered within levels one and two, or 0-20 cm bs. Debitage density abruptly terminates below $40 \mathrm{~cm}$ bs. Based upon the vertical distribution of this assemblage, a cultural zone is indicated at $0-40 \mathrm{~cm}$ bs. 



\section{Chapter 8: Recommendations}

The purpose of this testing project is to provide the Adjutant General's Office the NRHP eligibility status of 23 previously recorded prehistoric archaeological sites located within the TXARNG Camp Maxey training facility. These investigations were performed in light of the proposed development of roads, firebreaks, and general training areas within the facility. Through excavation of backhoe trenches, shovel tests, and/or manually excavated test units, the depositional integrity of each site was evaluated. With subsequent analyses of recovered artifacts and ecofacts, the temporal integrity of each site was similarly evaluated. The results of these evaluations were then combined in order to determine site significance. The significance of a prehistoric site under the National Historic Preservation Act is based on the site having yielded information important in history or prehistory or the site having the potential to yield such information in the future (36 CFR 60.4 Criterion (d)). The tabular summation (Table 6) provides CAR's recommendations for NRHP eligibility for each of the 23 sites.

The 19 sites lacking criteria necessary for inclusion in the NRHP have been adequately tested and no further archaeological investigations are recommended for these sites. Proposed development within these areas of potential impact should be permitted to proceed. The four sites recommended by CAR for NRHP eligibility should, minimally, be avoided during the proposed development within the facility. If avoidance for these significant sites is not possible under the proposed plan of work, then mitigative efforts in the form of archaeological data recovery should be implemented prior to development.

Table 6. Depositional integrity and eligibility status of the 23 previously recorded prehistoric sites

\begin{tabular}{|l|c|c|c|c|c|c|}
\hline Site & Integrity & Chronology & Technology & Subsistence & $\begin{array}{c}\text { Site } \\
\text { Structure }\end{array}$ & $\begin{array}{c}\text { NRHP } \\
\text { Eligibility }\end{array}$ \\
\hline 41LR152 & High & High & Moderate & Moderate & High & Eligible \\
\hline 41LR153 & Moderate & Low & Low & Low & Low & Not Eligible \\
\hline 41LR155 & Moderate & High & Low & None & Low & Not Eligible \\
\hline 41LR156 & Low & None & None & None & Low & Not Eligible \\
\hline 41LR157 & Low & Low & Low & Low & Low & Not Eligible \\
\hline 41LR158 & Low & None & Low & None & Moderate & Not Eligible \\
\hline 41LR160 & Moderate & None & Low & None & Low & Not Eligible \\
\hline 41LR163 & High & Moderate & Low & Low & Low & Not Eligible \\
\hline 41LR164 & Moderate & Moderate & High & High & Moderate & Eligible \\
\hline 41LR168 & Moderate & Low & Low & Low & Low & Not Eligible \\
\hline 41LR170 & None & High & Moderate & Moderate & Moderate & Not Eligible \\
\hline 41LR186 & Moderate & High & High & High & Moderate & Eligible \\
\hline 41LR187 & Moderate & High & High & High & Moderate & Eligible \\
\hline 41LR202 & Low & Low & Low & Low & Moderate & Not Eligible \\
\hline 41LR204 & Moderate & Moderate & Low & Low & Moderate & Not Eligible \\
\hline 41LR207 & Low & Low & Low & Low & Low & Not Eligible \\
\hline 41LR208 & Low & Moderate & Moderate & Low & Low & Not Eligible \\
\hline 41LR212 & Low & Moderate & Moderate & Low & High & Not Eligible \\
\hline 41LR260 & Low & High & Moderate & Moderate & Low & Not Eligible \\
\hline 41 L266 & Low & None & Low & None & Low & Not Eligible \\
\hline 41 LR268 & Moderate & Low & Moderate & Moderate & Moderate & Not Eligible \\
\hline 41LR285 & Moderate & None & Low & None & Moderate & Not Eligible \\
\hline 41LR286 & Moderate & Moderate & Low & Low & Low & Not Eligible \\
\hline
\end{tabular}




\section{Recommended Sites}

The following provides synopses for each site recommended for NRHP eligibility and a brief outline of recommended data recovery efforts necessary for mitigation of adverse effects to significant cultural resources.

\section{LR152}

Excavations at this site revealed a definable paleosol associated with a predominately ceramic artifact assemblage ascribed to Caddoan occupation. No temporally diagnostic lithic artifacts were recovered during either phase of investigations. Indications of a possible prehistoric burial and structure were encountered in the manually excavated test units. Radiocarbon assays have placed the possible burial early in the pre-Caddoan Woodland period and the later structure within the Formative Caddoan period.

Based upon these findings, this site has the potential to address the general research issues of integrity, chronology, technology, subsistence, and site structure. CAR therefore recommends that 41LR152 is significant and eligible for nomination to the NRHP. CAR further recommends that mitigative efforts in the form of archaeological data recovery be implemented prior to development.

\section{Data Recovery Outline}

Excavation of XUs 1 and 2 revealed indications of a possible structure and a possible burial, respectively. Accordingly, recommendation is made to further investigate these two areas of the site. A total of $50-\mathrm{m}^{2}$ is suggested as adequate to address the research issues mentioned above. Specifically, a $25-\mathrm{m}^{2}$ excavation block oriented north from XU 1, and a second identical block oriented south of XU 2 are recommended to investigate the two anomalies encountered at this site.

\section{LR164}

Test excavations at this site revealed a relatively dense zone of cultural material associated with a predominately lithic artifact assemblage ascribed to the Archaic era. Only one non-diagnostic native ceramic sherd was recovered during both phases of investigations. A diversity of subsistence activities is suggested with the recovered stone tool assemblage. Radiocarbon assays have placed the burned sandstone feature encountered in XU 1 in the pre-Caddoan Woodland period.

Based upon these findings, this site has the potential to address the general research issues of integrity, chronology, technology, subsistence, and site structure. CAR therefore recommends that 41LR164 is significant and eligible for nomination to the NRHP. CAR further recommends that mitigative efforts in the form of archaeological data recovery be implemented prior to development.

\section{Data Recovery Outline}

Excavation of XUs 1 and 6 and their associated BHTs recovered several stone tools atop the upland bankline along Visor Creek. Additional shovel tests within close proximity to these units returned similar results. Accordingly, recommendation is made to further investigate this dense area of the site. A total of $40-\mathrm{m}^{2}$ is suggested as adequate to address the research issues mentioned above. Specifically, a $40-\mathrm{m}^{2}$ excavation block oriented west from XU 6 is recommended to investigate this dense area of the site. 


\section{LR186}

Test excavations at this site revealed a relatively dense zone of cultural material associated with a mixed ceramic and lithic artifact assemblage ranging from the Late Archaic period to the Early Caddoan period. A diversity of subsistence activities is suggested with the recovered stone tool assemblage.

Based upon these findings, this site has the potential to address the general research issues of integrity, chronology, technology, subsistence, and site structure. CAR therefore recommends that 41LR186 is significant and eligible for nomination to the NRHP. CAR further recommends that mitigative efforts in the form of archaeological data recovery be implemented prior to development.

\section{Data Recovery Outline}

Excavation of XU 2 and the surrounding STs recovered several stone tools and native ceramics atop the upland landform. Additional shovel tests within close proximity to these units returned similar results. Accordingly, recommendation is made to further investigate this dense area of the site. A total of $40-\mathrm{m}^{2}$ is suggested as adequate to address the research issues mentioned above. Specifically, a 40- $\mathrm{m}^{2}$ excavation block oriented southwest from XU 2 is recommended to investigate this dense area of the site.
Test excavations at this site revealed a relatively dense zone of cultural material associated with a robust ceramic and moderate lithic artifact assemblage ranging from the Late Archaic period to the Early Caddoan period. Two sections of the site exhibit different ceramic chronological affiliations with possible changing temporal patterning in temper choices.

Based upon these findings, this site has the potential to address the general research issues of integrity, chronology, technology, subsistence, and site structure. CAR therefore recommends that 41LR187 is significant and eligible for nomination to the NRHP. CAR further recommends that mitigative efforts in the form of archaeological data recovery be implemented prior to development.

\section{Data Recovery Outline}

Excavation of several test units revealed two, separate areal concentrations of dense cultural material. Accordingly, recommendation is made to further investigate these two areas of the site. A total of $50-\mathrm{m}^{2}$ is suggested as adequate to address the research issues mentioned above. Specifically, a $25-\mathrm{m}^{2}$ excavation block oriented south from XU 2 and a second identical block situated between XU 1 and XU 4 are recommended to investigate these two areas. 



\section{References Cited}

Adjutant General's Department of Texas (AGD)

1993 Archeological Survey Report, October 4, 1993. Adjutant General's Department of Texas, Austin.

1997 Archeological Survey Report, July 1, 1997. Adjutant General's Department of Texas, Austin.

Banks, L. D.

1984 Lithic Resources and Quarries. In Prehistory of Oklahoma, edited by R. E. Bell, pp. 65-95. Academic Press.

Barnes, V. E.

1979 Geologic Atlas of Texas: Texarkana Sheet. Bureau of Economic Geology. The University of Texas at Austin.

Bousman, C. B.

1998 Paleoenvironmental Change in Central Texas: The Palynological Evidence. Plains Anthropologist 43(164):201-219.

Brown, J. A.

1996 The Spiro Ceremonial Center: The Archaeology of Arkansas Valley Caddoan Culture in Eastern Oklahoma. 2 Vols. Memoirs No. 29. Museum of Anthropology, University of Michigan, Ann Arbor.

Bruseth, J. E.

1998 The Development of Caddoan Polities along the Middle Red River Valley of Eastern Texas and Oklahoma. In The Native History of the Caddo: Their Place in Southeastern Archeology and Ethnohistory, edited by T. K. Perttula and J. E. Bruseth, pp. 47-68. Studies in Archeology 30. Texas Archeological Research Laboratory, The University of Texas at Austin.

Cliff, M. B., D. E. Peter, C. Stiles-Hanson, M. D. Freeman, and S. M. Hunt

1990 Cultural Resources Survey within Twelve Timber Cutting Areas, Louisiana Army Ammunition Plant, Webster and Bossier Parishes, Louisiana. Geo-Marine, Inc., Plano.

Collins, M. B.

1995 Forty Years of Archeology in Central Texas. Bulletin of the Texas Archeological Society 66:361-400.

Corbin, J. E.

1992 Archaeological Survey of a Proposed Raw Water Line (EDA, B4) for the City of Paris, Lamar County, Texas. Nacogdoches, Texas.

Crawford, C. A., and L. C. Nordt

2001 Geomorphology and Geoarchaeology of Camp Maxey. In Camp Maxey II, A 5,000-Acre Cultural Resource Survey of Camp Maxey, Lamar County, Texas, by A. S. Lyle, S. A. Tomka, and T. K. Perttula. Archaeological Survey Report, No. 312. Center for Archaeological Research, The University of Texas at San Antonio. 
Dillehay, T. D.

1974 Late Quaternary Bison Population Changes on the Southern Plains. Plains Anthropologist 19(65):180196.

Fox, D.

1979 An Archaeological Reconnaissance of Proposed Sewage Improvements for the City of Reno, Lamar County, Texas. C-48-1316. Texas Department of Water of Resources.

1981 An Archaeological Reconnaissance of Proposed Sewage Treatment Facilities for the City of Reno, Lamar County, Texas. C-48-1316. Texas Department of Water of Resources.

Girard, J. S.

2000 National Register Testing at the Conly Site (16BI19). In Regional Archaeology Program, Management Unit 1, Eleventh Annual Report, pp. 11-64. Louisiana Regional Archaeology Program, Natchitoches.

Gose, W. A., and D. L. Nickels

2001[1998] Archaeomagnetic and Magnetic Susceptibility Analyses. In Test Excavations at the Culebra Creek Site, 41BX126, Bexar County, Texas. D. L. Nickels, C. B. Bousman, J. D. Leach, and D. A. Cargill, pp. 204-214. Archaeological Survey Report, No. 265, Center for Archaeological Research, University of Texas at San Antonio; Archeology Studies Program, Report 3, Environmental Affairs Division, Texas Department of Transportation, Austin.

Harris, R. K., I. M. Harris, J. C. Blaine, and J. Blaine

1965 A Preliminary Archeological and Documentary Study of the Womack Site, Lamar County, Texas. Bulletin of the Texas Archeological Society 36:287-363.

Hyatt, R., and H. Mosca

1972 Survey of Cultural Resources of the Proposed Big Pine Lake, Lamar and Red River Counties, Texas. Produced for the United States Army Corps of Engineers - Tulsa District. Southern Methodist University.

Jackson, A. T., M. S. Goldstein, and A. D. Krieger

2000 The 1931 Excavations at the Sanders Site, Lamar County, Texas: Notes on the Fieldwork, Human Osteology, and Ceramics. Archival Series 2. Texas Archeological Research Laboratory, The University of Texas at Austin.

Johnson, L.

1989 Great Plains Interlopers in the Eastern Woodlands during Late Paleoindian Times: The Evidence from Oklahoma, Texas, and Areas Close By. Report Series 36. Office of the State Archeologist, Texas Historical Commission, Austin.

1995 Past Cultures and Climates at Jonas Terrace: 41ME29, Medina County, Texas. Office of the State Archeologist Report 40. Texas Historical Commission, Austin.

Johnson, L., and G. T. Goode

1994 A New Try at Dating and Characterizing Holocene Climates, as Well as Archeological Periods, on the Eastern Edward's Plateau. Bulletin of the Texas Archeological Society 65:1-51. 
Kelley, D. B., S. S. Victor, and M. Doty Freeman

1988 Archaeology in the Flatwoods: An Intensive Survey of Portions of the Louisiana Army Ammunition Plant, Bossier and Webster Parishes, Louisiana. Coastal Environments, Inc., Baton Rouge.

Kenmotsu, N. A., and T. K. Perttula (editors)

1993 Archeology in the Eastern Planning Region, Texas: A Planning Document. Cultural Resource Management Report 3. Department of Antiquities Protection, Texas Historical Commission, Austin.

Krieger, A. D.

1946 Culture Complexes and Chronology in Northern Texas, with Extensions of Puebloan Datings to the Mississippi Valley. Publication No. 4640. The University of Texas at Austin.

Lorrain, D., and N. Hoffrichter

1968 Archeological Survey and Excavation at Pat Mayse Reservoir, Texas. Archeological Salvage Project, Southern Methodist University, Dallas.

Luke, C.

1978 Initial Testing Report for 41LR58, Lamar County, Texas. State Department of Highways and Public Transportation.

Lyle, A. S., S. A. Tomka, and T. K. Perttula

2001 Camp Maxey II, A 5,000-Acre Cultural Resource Survey of Camp Maxey, Lamar County, Texas. Archaeological Survey Report, No. 312. Center for Archaeological Research, The University of Texas at San Antonio.

Mahoney, R. B., and S. A. Tomka

2001 National Register Eligibility Testing of 41MM340 and 41MM341, along Little River, Milam County, Texas. Archaeological Survey Report, No. 303, Center for Archaeological Research, The University of Texas at San Antonio; Archeological Studies Program, Report No. 30, Environmental Affairs Division, Texas Department of Transportation, Austin.

Mallouf, R. J.

1976 Archeological Investigations at Proposed Big Pine Lake, 1974-1975: Lamar and Red River Counties, Texas. Archeological Survey Report No. 18. Office of the State Archeologist, Texas Historical Commission, Austin.

Nickels, D. L, L. C. Nordt, T. K. Perttula, C. B. Bousman, and K. H. Miller

1998 Archaeological Survey of Southwest Block and Selected Roads and Firebreaks at Camp Maxey, Lamar County, Texas. Archaeological Survey Report, No. 290. Center for Archaeological Research, The University of Texas at San Antonio.

Nordt, L. C., and C. B. Bousman.

1998 Fluvial Geomorphology and Geoarchaeology of Visor Creek. In Archaeological Survey of Southwest Block and Selected Roads and Firebreaks at Camp Maxey, Lamar County, Texas, by D. L. Nickels, L. C. Nordt, T. K. Perttula, C. B. Bousman, and K. Miller. Archaeological Survey Report, No. 290, Center for Archaeological Research at San Antonio. 
Perttula, T. K.

1992 The Caddo Nation: Archaeological and Ethonohistorical Perspectives. University of Texas Press, Austin.

1997 The Archaeology of the Middle Caddoan Period in the Middle Red River Valley of Northeast Texas. Journal of Northeast Texas Archaeology 10:47-51.

Perttula, T. K. (editor)

1999 The Hurricane Hill Site (41HP106): The Archaeology of a Late Archaic/Early Ceramic and EarlyMiddle Caddoan Settlement in Northeast Texas. 2 Vols. Special Publication No. 4. Friends of Northeast Texas Archaeology, Pittsburg and Austin.

Perttula, T. K., J. E. Bruseth, N. A. Kenmotsu, D. J. Prikryl, W. A. Martin, L. Banks, J. Smith, N. G. Reese, and S. A. Iruegas

2001 Archeological Investigations on the Red River and Tributaries: Summary of the Findings of the 1991 and 1992 Texas Archeological Field School in Red River and Lamar Counties, Texas. Bulletin of the Texas Archeological Society 72:165-250.

Perttula, T. K., and R. Nathan

1988 Cultural Resources Survey of the Natural Gas Pipeline Company of America Southern Interconnect Pipeline, Lamar, Red River, Franklin, Morris, and Cass Counties, Texas. Institute of Applied Sciences, North Texas State University.

Perttula, T. K, R. C. Fields, J. E. Corbin, and N. A. Kenmotsu

1993 The Emergence of Sedentism in Northeast Texas, ca. 500 B.C. to A.D. 1000. In Archeology in the Eastern Planning Region, Texas: A Planning Document, edited by N. A. Kenmotsu and T. K. Perttula. Cultural Resource Management Report 3. Department of Antiquities Protection, Texas Historical Commission, Austin.

Perttula, T. K., B. D. Skiles, M. B. Collins, M. C. Trachte, and F. Valdez, Jr.

1986 "This Everlasting Sand Bed": Cultural Resources Investigations at the Texas Big Sandy Project, Wood and Upshur Counties, Texas. Reports of Investigations, Number 52. Prewitt and Associates, Austin.

Prewitt, E. R.

1981 Cultural Chronology in Central Texas. Bulletin of the Texas Archeological Society 52:65-89.

1985 From Circleville to Toyah: Comments on Central Texas Chronology. Bulletin of the Texas Archeological Society 54:201-238.

Quigg, J. M.

2000 The Lino Site: A Stratified Late Archaic Campsite in a Terrace of San Idelfonzo Creek, Webb County, Southern Texas. Technical Report No. 23756, TRC Mariah Associates; Archaeological Studies Program, Report No. 20, Environmental affairs Division, Texas Department of Transportation, Austin.

Ressel, D.

1979 Soil Survey of Lamar and Delta Counties. U.S. Department of Agriculture-Soil Conservation Service. U.S. Government Printing Office, Washington, D.C. 
Rice, P. M.

1987 Pottery Analysis: A Sourcebook. University of Chicago Press, Chicago.

Rodgers, R.

1994 Excavations at Site 41GM224 in the Gibbons Creek Lignite Mine, Permit 38A Area, Grimes County, Texas. Texas Antiquities Committee Permit No. 1245. Espey, Huston and Associates, Inc., Austin.

Rogers, R., and T. K. Perttula

1999 The Oak Hill Village Site (41RK214), Rusk County, Texas. Review Draft. 3 Vols. Document No. 990305. PBS\&J, Austin.

Schambach, F. F.

1998 Pre-Caddoan Cultures of the Trans-Mississippi South: A Beginning Sequence. Research Series 53. Arkansas Archeological Survey, Fayetteville.

2000 The Significance of the Sanders Site in the Culture History of the Mississippi Period Southeast and the Southern Plains. In The 1931 Excavations at the Sanders Site, Lamar County, Texas: Notes on the Fieldwork, Human Osteology, and Ceramics, by A. T. Jackson, M. S. Goldstein, and A. D. Krieger, pp. 1-7. Archival Series 2. Texas Archeological Research Laboratory, The University of Teas at Austin.

Shafer, H. J.

1965 Archeological Surveys of Honea, Pat Mayse, and Halsell Reservoirs, Texas. Survey Report No. 1. Texas Archeological Salvage Project.

Soil Survey Division Staff

1993 Soil Survey Manual. U.S. Department of Agriculture Handbook Number 18. U.S. Government Printing Press, Washington, D.C.

Story, D. A.

1990 Cultural History of the Native Americans. In Archeology and Bioarcheology of the Gulf Coastal Plain, by D. A. Story, J. A. Guy, B. A. Burnett, M. D. Freeman, J. C. Rose, D. G. Steele, B. W. Olive, and K. J. Reinhard, pp. 163-366. Research Series No. 38, Arkansas Archeological Survey, Fayetteville.

Sullo, D. M., and S. C. Stringer

1998 Cultural Resource Investigations for Minor Construction Projects, Camp Maxey, Lamar County, Texas. Adjutant General's Department of Texas, Austin.

Suhm, D. A., and E. B. Jelks

1962 Handbook of Texas Archeology: Type Descriptions. The Texas Archeological Society Special Publication No. 1 and Texas Memorial Museum Bulletin No. 4. The Texas Archeological Society and the Texas Memorial Museum, Austin.

Stuvier, M., and P. J. Reimer

1993 Extended ${ }^{14} \mathrm{C}$ Database and Revised CALIB Radiocarbon Calibration Program, Radiocarbon 35:215230.

Teltser, P. A.

1993 An Analytic Strategy for Studying Assemblage-Scale Ceramic Variation: A Case Study from Southeast Missouri. American Antiquity 58(3):530-543. 
Texas State Department of Highways and Public Transportation 1948[1936] Highway map of Lamar County.

Thoms, A. V.

1993a The Brazos Valley Slopes Archaeological Project: Cultural Resources Assessments for the Proposed Texas A\&M University Wastewater Treatment Plant, Brazos County, Texas. Reports of Investigations No. 13. Archaeological Research Laboratory, Texas A\&M University, College Station.

1993b The Brazos Valley Slopes Archaeological Project: Cultural Resources Assessments for the Proposed Texas A\&M University Animal Science Teaching and Research Complex, Brazos County, Texas. Reports of Investigations No. 14. Archaeological Research Laboratory, Texas A\&M University, College Station.

Waters, M. R.

1992 Principles of Geoarchaeology: A North American Perspective. University of Arizona Press, Tuscon.

Waters, M., and L. Nordt

1996 Geomorphic Reconnaissance of Selected Segments of the MIDTEXAS Pipeline. Archaeological Survey of the Proposed 130-Mile MIDTEXAS Pipeline, Gonzales, Dewitt, Lavaca, Colorado, Austin, and Waller Counties, Texas, edited by K. A. Miller, pp. 39-68. SWCA Archaeological Report No. 95-154. SWCA Environmental Consultants, Inc., Austin.

Wood, W. R.

1998 Archaeology on the Great Plains. The University Press of Kansas, Lawrence.

Wyckoff, D. G.

1984 The Foragers: Eastern Oklahoma. In Prehistory of Oklahoma, edited by Robert E. Bell, pp. 119-160. Academic Press.

Young, W. C.

1984 Archaeological Testing of Site 41LR92, Lamar County, Texas. State Department of Highways and Public Transportation. 


\section{Appendix A}

Soil Profile Descriptions 


\section{BHT 1; site 285 (BHT 1); flood terrace; noncalcareous throughout.}

0-5 cm; very dark grayish brown (10YR 3/2) fibrous root mass.

A1 5-12 cm; Holocene; brown (10YR 3/3) loamy fine sand; moderate fine subangular blocky; very friable; common fine roots; gradual smooth.

A2 12-31 cm; dark yellowish brown (10YR 4/4) loamy fine sand; moderate fine and medium subangular blocky; very friable; common fine to coarse roots; clear smooth.

E 31-63 cm; yellowish brown (10YR 5/4) loamy fine sand; moderate medium subangular blocky; very friable; few medium prominent black (10YR 2/1) iron manganese nodules; common fine to medium roots; abrupt smooth.

Bt 63-83 cm; Pre-Holocene; light yellowish brown (10YR 6/4) clay loam; weak medium angular blocky; firm; few medium prominent red (2.5YR 5/8) soft iron masses; few medium prominent black (10YR 2/1) iron manganese nodules; few fine roots;

Btg 83-100 cm; light brownish gray (2.5Y 6/2) loam; moderate medium prismatic to moderate medium angular blocky; firm; many medium and coarse prominent red (2.5YR 4/8) soft iron masses; common medium prominent black (10YR 2/1) iron manganese nodules.

\section{BHT 2; site 285 (BHT 2); flood terrace; noncalcareous throughout.}

A $\quad$ 0-30 cm; Holocene; brown (7.5YR 4/4) loamy fine sand; moderate fine to medium subangular blocky; very friable; common fine to medium roots; clear smooth.

E $\quad 30-53 \mathrm{~cm}$; brown (7.5YR 4/4) loamy fine sand; weak coarse prismatic to weak medium angular blocky; very friable; few fine faint strong brown (7.5YR 4/6) soft iron masses; few fine prominent black (10YR 2/1) iron manganese nodules; common fine and medium roots; clear smooth.

Eg $\quad 53-69 \mathrm{~cm}$; brown (7.5YR 4/4) loamy fine sand; weak medium to coarse prismatic to weak coarse angular blocky; very friable; many medium to coarse distinct yellowish red (5YR 4/6) soft iron masses; few medium prominent black (10YR 2/1) iron manganese nodules; abrupt smooth.

Btc 69-100 cm; strong brown (7.5YR 4/6) clay; massive; firm; many coarse to extremely coarse prominent dark red (2.5YR 3/6) and black (10YR 2/1) iron manganese concretions.

\section{BHT 3; site 204 (BHT 4); high terrace; noncalcareous throughout.}

A1 0-10 cm; Pre-Holocene; brown (10YR 4/3) loamy fine sand; moderate fine subangular blocky; very friable; common fine roots; gradual smooth.

A2 10-29 cm; dark yellowish brown (10YR 4/4) loamy fine sand; moderate fine to medium subangular blocky; very friable; few medium prominent black (10YR 2/1) iron manganese nodules; few fine roots; gradual smooth.

E 29-49 cm; brown (10YR 5/3) loamy fine sand; weak medium to coarse prismatic; very friable; few fine prominent yellowish red (5YR 5/8) soft iron masses; few medium prominent black (10YR 2/1) iron manganese nodules; few fine roots; abrupt smooth.

Bt 49-100 cm; strong brown (7.5YR 5/8) clay; weak medium prismatic; firm; common medium faint strong brown (7.5YR 4/6) clay films on ped facies; few medium prominent black (10YR 2/1) iron manganese nodules; few fine and medium roots. 


\section{BHT 4; site 207 (BHT 1); terrace; noncalcareous throughout.}

A1 0-17 cm; Pre-Holocene; brown (10YR 5/3) loamy fine sand; moderate medium subangular blocky; very friable; few fine and medium roots; gradual smooth.

A2 17-40 cm; yellowish brown (10YR 5/4) loamy fine sand; moderate medium subangular blocky; very friable; few fine and medium roots; gradual smooth.

E $\quad 40-69 \mathrm{~cm}$; yellowish brown (10YR 5/4) loamy fine sand; weak medium to coarse prismatic; very friable; common medium distinct strong brown (7.5YR 5/6) soft iron masses; few fine and medium roots; clear smooth.

C $\quad 69-130 \mathrm{~cm}$; strong brown (7.5YR 5/6) fine sandy loam; weak coarse prismatic; friable; common medium faint strong brown (7.5YR 4/6) clay films on ped facies; few medium prominent black (10YR 2/1) iron manganese nodules.

\section{BHT 5; site 207 (BHT 3); shoulder slope; noncalcareous throughout.}

A $\quad$-14 cm; Pre-Holocene; brown (10YR 4/3) loamy fine sand; moderate medium subangular blocky; very friable; common fine and medium roots; gradual smooth.

E $\quad$ 14-34 cm; yellowish brown (10YR 5/4) loamy fine sand; moderate medium subangular blocky; very friable; common medium distinct yellowish red (5YR 5/8) soft iron masses; few medium prominent black (10YR 2/1) iron manganese nodules; few fine and medium roots; abrupt smooth.

Bt 34-100 cm; yellowish red (5YR 4/6) clay loam; weak medium prismatic; firm; common medium distinct red (2.5YR 4/6) clay films on ped facies; common medium prominent brownish yellow (10YR 6/6) sand coats; common medium prominent red (10R 4/8) soft iron masses.

\section{BHT 6; site 152 (BHT 3); flood terrace; noncalcareous throughout.}

A1 0-17 cm; Holocene; brown (7.5YR 4/3) loamy fine sand; moderate fine to medium subangular blocky; very friable; common fine roots; gradual smooth.

A2 17-31 cm; brown (7.5YR 4/4) loamy fine sand; moderate medium subangular blocky; very friable; common fine and medium roots; gradual smooth.

E $\quad 31-46 \mathrm{~cm}$; strong brown (7.5YR 4/6) loamy fine sand; weak medium prismatic; very friable; few fine and medium roots; clear smooth.

Bt1 46-72 cm; Pre-Holocene; strong brown (7.5YR 5/6) fine sandy loam; weak coarse prismatic; friable; common medium faint strong brown (7.5YR 4/6) clay films on ped facies; common medium faint brown (7.5YR 5/4) sand coats; common fine prominent black (10YR 2/1) iron manganese nodules; few fine roots; gradual smooth.

Bt2 72-118 cm; strong brown (7.5YR 5/6) fine sandy loam; weak coarse prismatic; friable; common medium to coarse faint strong brown (7.5YR 4/6) clay films on ped facies; many medium to coarse faint brown (7.5YR 5/4) sand coats; common medium prominent black (10YR 2/1) iron manganese nodules; gradual smooth.

Btg 118-150 cm; brown (7.5YR 5/3) clay loam; weak coarse prismatic; firm; common medium to coarse faint strong brown (7.5YR 4/6) clay films on ped facies; common medium distinct yellowish red (5YR 4/6) and strong brown (7.5YR 5/8) soft iron masses. 


\section{BHT 7; site 153 (BHT 1); high terrace; noncalcareous throughout.}

A1 0-9 cm; Pre-Holocene; brown (10YR 4/3) loamy fine sand; moderate fine subangular blocky; very friable; common fine roots; clear smooth.

A2 9-25 cm; strong brown (7.5YR 4/6) loamy fine sand; moderate fine to medium subangular blocky; very friable; few fine to medium prominent black (10YR 2/1) iron manganese nodules; common fine roots; gradual smooth.

E1 25-44 cm; strong brown (7.5YR 5/6) loamy fine sand; moderate fine to medium subangular blocky; very friable; few medium distinct yellowish red (5YR 4/6) clay films on ped facies; few fine to medium prominent black (10YR 2/1) iron manganese nodules; common fine roots; gradual smooth.

E2 44-54 cm; light yellowish brown (10YR 6/4) loamy fine sand; weak medium prismatic; very friable; many medium distinct yellowish red (5YR 4/6) clay films on ped facies; few fine to medium prominent black (10YR 2/1) iron manganese nodules; few fine roots; abrupt smooth.

Bt 54-78 cm; yellowish brown (10YR 5/6) fine sandy clay loam; weak medium prismatic; firm; many medium prominent yellowish red (5YR 4/6) clay films on ped facies; common medium faint light yellowish brown (10YR 6/4) sand coats; few medium prominent red (2.5YR 4/8) soft iron masses; few medium prominent black (10YR 2/1) iron manganese nodules; clear smooth.

Btv 78-120 cm; light brownish gray (2.5Y 6/2) clay; weak coarse prismatic; firm; few medium faint olive yellow (2.5Y 6/ 6) sand coats; many medium to coarse prominent reddish brown (2.5YR 4/4) and red (2.5YR 4/6) soft iron masses and plinthite.

\section{BHT 8; site 160 (BHT 1); flood terrace; noncalcareous throughout.}

A $\quad 0-29 \mathrm{~cm}$; Holocene; dark yellowish brown (10YR 4/4) loamy fine sand; moderate medium subangular blocky; very friable; common fine roots; gradual smooth.

Bw1 29-56 cm; dark yellowish brown (10YR 4/6) loamy fine sand; moderate medium subangular blocky; very friable; few fine to medium roots; gradual smooth.

Bw2 56-110 cm; Pre-Holocene; yellowish brown (10YR 5/6) loamy fine sand; weak coarse prismatic; very friable; few medium prominent black (10YR 2/1) iron manganese nodules; gradual smooth.

Bw3 110-142 cm; light yellowish brown (10YR 6/4) loamy fine sand; weak coarse prismatic; very friable; common medium distinct strong brown (7.5YR 5/6, 5/8) soft iron masses; common medium prominent black (10YR 2/1) iron manganese nodules; gradual smooth.

Bw4 142-170 cm; pale yellow (2.5Y 7/3) loamy fine sand; weak medium to coarse prismatic; very friable; many medium to coarse prominent yellowish red (5YR 4/6, 5/8) soft iron masses.

\section{BHT 9; site 160 (BHT 3); flood terrace; noncalcareous throughout.}

A1 0-15 cm; Holocene; brown (10YR 4/3) loamy fine sand; moderate fine to medium subangular blocky; very friable; common fine roots; gradual smooth.

A2 15-31 cm; dark yellowish brown (10YR 4/4) loamy fine sand; moderate medium subangular blocky; very friable; few fine and medium roots; clear smooth.

E 31-74 cm; dark yellowish brown (10YR 4/6) loamy fine sand; weak coarse prismatic; very friable; few medium prominent black 10YR 2/1) iron manganese nodules; few fine and medium roots; abrupt smooth.

Btg 74-115 cm; Pre-Holocene; light gray (10YR 7/2) loamy fine sand; weak coarse prismatic; friable; many coarse prominent reddish brown (5YR 4/4) clay films on ped facies; many medium prominent strong brown (7.5YR 5/8) soft iron masses; few medium prominent red (2.5YR 4/4) plinthite. 


\section{BHT 10; site 164 (BHT 10); high terrace; noncalcareous throughout.}

A1 0-12 cm; Pre-Holocene; brown (10YR 4/3 loamy fine sand; moderate fine subangular blocky; very friable; common fine roots; gradual smooth.

A2 12-31 cm; dark yellowish brown (10YR 4/4) loamy fine sand; moderate fine to medium subangular blocky; very friable; common fine and medium roots; clear smooth.

E1 31-62 cm; strong brown (7.5YR 4/6) loamy fine sand; weak coarse prismatic; very friable; common medium distinct yellowish red (5YR 4/6) biocasts; few medium prominent black (10YR 2/1) iron manganese nodules; few fine and medium roots; $2 \%$ 2-3 cm diameter, well sorted, subrounded siliceous pebbles; gradual smooth.

E2 62-90 cm; yellowish red (5YR 4/6) loamy fine sand; weak coarse prismatic; very friable; few medium distinct light yellowish brown (10YR 6/4) biocasts; few medium prominent black (10YR 2/1) iron manganese nodules; $2 \% 2-3 \mathrm{~cm}$ diameter, well sorted, subrounded siliceous pebbles; clear smooth.

Bt 90-117 cm; brownish yellow (10YR 6/6) fine sandy loam; weak coarse prismatic; friable; few fine to medium prominent red (2.5YR 4/8) yellowish red (5YR 4/6, 5/8) soft iron masses and plinthite; $2 \%$ 2-3 cm diameter, well sorted, subrounded siliceous pebbles; abrupt smooth.

Btv 117-175 cm; light yellowish brown (2.5Y 6/3) fine sandy clay loam; weak medium prismatic; friable; many medium prominent dark red (10R 3/6) and red (2.5YR 4/8) soft iron masses and plinthite.

\section{BHT 11; site 164 (BHT 5); flood terrace; noncalcareous throughout.}

A $\quad 0-25 \mathrm{~cm}$; Holocene; brown (10YR 4/3) loamy fine sand; moderate medium subangular blocky; very friable; common fine and medium roots; clear smooth.

E 25-42 cm; yellowish brown (10YR 5/4) loamy fine sand; weak coarse prismatic; very friable; few fine to medium roots; clear smooth.

Bt1 42-61 cm; Pre-Holocene; yellowish red (5YR 5/8) fine sandy clay loam; weak medium prismatic; firm; few fine to medium black (10YR 2/1) iron manganese nodules; few fine to medium roots; clear smooth.

Bt2 61-90 cm; yellowish red (5YR 5/8) fine sandy clay loam; weak medium prismatic; firm; common medium distinct dark red (10R 3/6) and red (2.5YR 4/8) soft iron masses; common medium to coarse distinct black (10YR 2/1) iron manganese nodules; few fine to medium roots.

\section{BHT 12; site 164 (BHT 7); flood terrace; noncalcareous throughout.}

A $\quad$ 0-16 cm; Holocene; brown (10YR 4/3) loamy fine sand; moderate fine subangular blocky; very friable; few fine distinct strong brown (7.5YR 5/6) soft iron masses; few fine distinct strong brown (7.5YR 5/6) pore linings; common fine to medium roots; clear smooth.

Btv1 16-54 cm; Pre-Holocene; yellowish brown (10YR 5/6) fine sandy clay loam; weak medium to coarse prismatic; firm; common medium prominent red (10R 4/6) and yellowish red (5YR 5/8) soft iron masses and plinthite; few fine and medium roots; clear smooth.

Btv2 $54-85 \mathrm{~cm}$; light yellowish brown (2.5Y 6/3) fine sandy clay loam; weak coarse prismatic; firm; many medium prominent dark red (10R 3/6) and red (2.5YR 4/8) soft masses and plinthite; few fine to medium roots. 


\section{BHT 13; site 164 (BHT 4); terrace; noncalcareous throughout.}

A $\quad 0-23 \mathrm{~cm}$; Pre-Holocene; yellowish brown (10YR 5/4) loamy fine sand; moderate fine to medium subangular blocky; very friable; common fine roots; gradual smooth.

E 23-44 cm; yellowish brown (10YR 5/6) loamy fine sand; weak coarse prismatic; very friable; few medium distinct strong brown (7.5YR 5/8) soft iron masses; few fine to medium roots; clear smooth.

Bt $\quad 44-71 \mathrm{~cm}$; strong brown (7.5YR 5/8) fine sandy loam; weak coarse prismatic; firm; few medium faint yellowish red (5YR 4/6) clay films on ped facies; clear smooth.

Btv 71-95 cm; pale yellow (2.5Y 7/3) and olive yellow (2.5Y 6/6) fine sandy loam; weak coarse prismatic; firm; many medium prominent dark red (10R 3/6) and red (2.5YR 5/8) soft iron masses and plinthite.

\section{BHT 14; site 164 (BHT 9); terrace; noncalcareous throughout.}

A1 0-11 cm; Pre-Holocene; brown (10YR 4/3) loamy fine sand; moderate fine subangular blocky; very friable; common fine roots; $2 \%$ 0.5-1 cm diameter, moderately well sorted; subangular to subrounded siliceous pebbles; gradual smooth.

A2 11-18 cm; dark yellowish brown (10YR 4/4) loamy fine sand; moderate fine to medium subangular blocky; very friable; common fine roots; $2 \% 0.5-1 \mathrm{~cm}$ diameter, moderately well sorted; subangular to subrounded siliceous pebbles; clear smooth.

E $\quad 18-30 \mathrm{~cm}$; yellowish brown (10YR 5/4) loamy fine sand; weak coarse prismatic; very friable; common fine to medium prominent red (10R 4/6, 2.5YR 4/8) soft iron masses; common fine to medium prominent black (10YR 2/1) iron manganese nodules; few fine roots; $2 \% 0.5-1 \mathrm{~cm}$ diameter, moderately well sorted; subangular to subrounded siliceous pebbles; abrupt smooth.

Bt 30-60 cm; red (2.5YR 4/8) clay loam; weak medium prismatic; firm; few medium distinct strong brown (7.5YR 5/8) biocasts; many medium faint red (2.5YR 4/6) clay films on ped facies; abrupt smooth.

C1 60-83 cm; red (2.5YR 4/8) and reddish yellow (7.5YR 6/8) fine sandy loam; massive; firm; common medium to coarse prominent dark red (10R 3/6) clay films on ped facies; common medium prominent black (10YR 2/1) iron manganese nodules; light yellowish brown $(2.5 \mathrm{Y} 6 / 3) 1 \mathrm{~cm}$ thick laminations in lower part; abrupt smooth.

C2 83-100 cm; red (2.5YR 4/8) and yellowish red (5YR 5/8) loamy fine sand; massive; friable.

\section{BHT 15; site 158 (BHT 1); terrace; noncalcareous throughout.}

A $\quad$-20 cm; Pre-Holocene; brown (10YR 4/3) loamy fine sand; moderate medium subangular blocky; very friable; common fine roots; clear smooth.

E $\quad 20-48 \mathrm{~cm}$; dark yellowish brown (10YR 4/4) loamy fine sand; moderate fine to medium subangular blocky; very friable; common medium prominent yellowish red (5YR 5/8) soft iron masses; few medium prominent black (10YR $2 / 1$ ) iron manganese nodules; few fine to medium roots; abrupt smooth.

Bt $\quad 48-75 \mathrm{~cm}$; yellowish red (5YR 4/6) fine sandy clay loam; weak coarse prismatic; firm; many medium distinct red (2.5YR 4/8) clay films; $7 \% 2-5 \mathrm{~cm}$ diameter, moderately well sorted, subrounded to rounded siliceous pebbles. 


\section{BHT 16; site 158 (BHT 4); high terrace; noncalcareous throughout.}

A $\quad 0-12 \mathrm{~cm}$; Pre-Holocene; brown (10YR 4/3) loamy fine sand; moderate fine to medium subangular blocky; very friable; common fine roots; gradual smooth.

E1 12-43 cm; dark yellowish brown (10YR 4/4) loamy fine sand; moderate medium subangular blocky; very friable; few fine prominent black (10YR 2/1) iron manganese nodules; few fine to medium roots; $2 \% 2-4 \mathrm{~cm}$ diameter, moderately well sorted, subrounded to rounded siliceous pebbles; clear smooth.

E2 43-82 cm; strong brown (7.5YR 4/6) loamy fine sand; weak coarse prismatic; very friable; common medium faint strong brown (7.5YR 5/8) soft iron masses; few fine prominent black (10YR 2/1) iron manganese nodules; few fine roots; $2 \%$ 2-4 cm diameter, moderately well sorted, subrounded to rounded siliceous pebbles; abrupt smooth.

Bt $82-112 \mathrm{~cm}$; brownish yellow (10YR 6/6) fine sandy clay loam; moderate medium prismatic; firm; many medium prominent dark red (2.5YR 3/6) and red (2.5YR 4/8) soft iron masses and plinthite; abrupt smooth.

Btv 112-140 cm; light yellowish brown (2.5Y 6/4) fine sandy loam; weak coarse prismatic; firm; many medium to coarse faint pale yellow (2.5Y 7/3) sand coats; many medium prominent red (10R 4/6, 4/8) soft iron masses and plinthite.

\section{BHT 17; site 260 (BHT 6); high terrace; noncalcareous throughout.}

A1 0-7 cm; Pre-Holocene; brown (10YR 5/3) loamy fine sand; moderate fine to medium subangular blocky; very friable; common fine roots; clear smooth.

A2 7-24 cm; yellowish brown (10YR 5/4) loamy fine sand; moderate medium subangular blocky; very friable; common fine to medium roots; gradual smooth.

E1 24-59 cm; light yellowish brown (10YR 6/4) loamy fine sand; weak coarse prismatic; very friable; few fine and medium roots; $2 \%$ 1-4 cm diameter, moderately well sorted, subrounded pebbles; gradual smooth.

E2 59-80 cm; yellowish brown (10YR 5/6) loamy fine sand; weak coarse prismatic; very friable; few fine roots; $2 \%$ 1-4 cm diameter, moderately well sorted, subrounded pebbles; abrupt smooth.

Bt $\quad 80-110 \mathrm{~cm}$; strong brown (7.5YR 5/6) fine sandy clay loam; weak coarse prismatic; friable; common medium distinct yellowish red (5YR 5/6) clay films.

\section{BHT 18; site 260 (BHT 1); high terrace; noncalcareous throughout.}

A $\quad$-21 cm; Pre-Holocene; brown (10YR 4/3) loamy sand; moderate fine to medium subangular blocky; very friable; common fine roots; clear smooth.

Bw1 21-71 cm; dark yellowish brown (10YR 4/4) loamy sand; moderate medium to coarse subangular blocky; very friable; few fine and medium roots; $2 \% 1-3 \mathrm{~cm}$ diameter, moderately well sorted, subrounded siliceous pebbles; gradual smooth.

Bw2 71-138 cm; strong brown (7.5YR 4/6) loamy sand; weak coarse prismatic; very friable; common medium distinct yellowish brown (5YR 4/6) clay films; few fine and medium roots; 3\% 1-4 cm diameter, moderately well sorted, subrounded siliceous pebbles; clear smooth.

BC 138-183 cm; brown (7.5YR 5/4) loamy sand; weak coarse prismatic; very friable; many medium to coarse distinct yellowish brown (5YR 4/6) clay films; few medium roots; $10 \% 1-5 \mathrm{~cm}$ diameter, moderately well sorted, subrounded siliceous pebbles; clear smooth.

C $\quad 183-215 \mathrm{~cm}$; very pale brown (10YR 7/4) sand; massive; very friable; many medium to coarse prominent yellowish brown (5YR 4/6) clay films; $2 \% 1-4 \mathrm{~cm}$ diameter, moderately well sorted, subrounded siliceous pebbles. 


\section{BHT 19; site 260 (BHT 2); high terrace; noncalcareous throughout.}

A1 0-10 cm; Pre-Holocene; brown (10YR 5/3) loamy sand; moderate fine to medium subangular blocky; very friable; common fine and medium roots; clear smooth.

A2 10-24 cm; yellowish brown (10YR 5/4) loamy sand; moderate medium subangular blocky; very friable; few fine and medium roots; gradual smooth.

E1 24-60 cm; yellowish brown (10YR 5/4) loamy sand; weak coarse prismatic; very friable; few fine and medium roots; gradual smooth.

E2 $\quad 60-80 \mathrm{~cm}$; light yellowish brown (10YR 6/4) loamy sand; weak coarse prismatic; very friable; few fine and medium roots; $2 \%$ 1-3 cm diameter, moderately well sorted, subrounded siliceous pebbles; abrupt smooth.

Btv 80-100 cm; light yellowish brown (2.5Y 6/3) clay; weak coarse prismatic; firm; few medium distinct olive yellow (2.5Y 6/6) sand coats; many medium to coarse prominent reddish brown (2.5YR 4/4) and red (2.5YR 4/6) soft iron masses and plinthite.

\section{BHT 20; site 260 (BHT 3); flood terrace; noncalcareous throughout.}

A1 0-11 cm; Holocene; brown (10YR 5/3) loamy fine sand; moderate fine to medium subangular blocky; very friable; common fine roots; gradual smooth.

A2 11-24 cm; yellowish brown (10YR 5/4) loamy fine sand; moderate medium subangular blocky; very friable; common fine and medium roots; gradual smooth.

E1 24-55 cm; light yellowish brown (10YR 6/4) loamy fine sand; moderate medium to coarse subangular blocky; very friable; few medium roots; gradual smooth.

E2 $55-78 \mathrm{~cm}$; pale yellow (2.5Y 7/3) loamy fine sand; weak coarse prismatic; very friable; few medium roots; $2 \% 1-3 \mathrm{~cm}$ diameter, moderately well sorted, subrounded siliceous pebbles; clear smooth.

Bt 78-103 cm; Pre-Holocene; light yellowish brown (2.5Y 6/4) fine sandy loam; weak coarse prismatic; friable; common medium prominent yellowish red (5YR 5/8) and strong brown (7.5YR 5/8) soft iron masses; clear smooth.

Btg 103-150 cm; light gray (2.5Y 7/1) fine sandy loam; weak coarse prismatic; friable; many medium prominent yellowish red (5YR 5/8) and strong brown (7.5YR 5/8) soft iron masses.

\section{BHT 21; site 208 (BHT 2); terrace; noncalcareous throughout.}

A $\quad 0-12 \mathrm{~cm}$; Pre-Holocene; brown (10YR 4/3) loamy fine sand; moderate fine to medium subangular blocky; very friable; few fine prominent black (10YR 2/1) iron manganese nodules; gradual smooth.

E $\quad 12-40 \mathrm{~cm}$; dark yellowish brown (10YR 4/4) loamy fine sand; moderate medium subangular blocky; very friable; few fine and coarse prominent black (10YR 2/1) iron manganese nodules; clear smooth.

Bt1 40-61 cm; strong brown (7.5YR 5/8) fine sandy clay loam; weak coarse prismatic; firm; common medium prominent red (2.5YR 4/6) clay films; few fine and coarse prominent black (10YR 2/1) iron manganese nodules; gradual smooth.

Bt2 61-83 cm; strong brown (7.5YR 5/6) fine sandy clay loam; weak coarse prismatic; firm; few medium distinct yellowish brown (10YR 5/8) sand coats; common medium prominent red (2.5YR 4/6) clay films; few fine and coarse prominent black (10YR 2/1) iron manganese nodules; $2 \% 1-5 \mathrm{~cm}$ diameter, moderately well sorted, subrounded siliceous pebbles; abrupt smooth.

Btv $\quad 83-115 \mathrm{~cm}$; light brownish gray (2.5Y 6/2) fine sandy clay loam; weak coarse prismatic; firm; many medium to coarse prominent red (2.5YR 4/8) soft iron masses and plinthite; few medium prominent strong brown (7.5YR 5/8) soft iron masses; few fine to coarse iron manganese nodules. 


\section{BHT 22; site 187 (BHT 2); high terrace; noncalcareous throughout.}

A 0-22 cm; Pre-Holocene; dark yellowish brown (10YR 4/4) loamy sand; moderate medium subangular blocky; very friable; common fine and medium roots; gradual smooth.

E1 22-42 cm; yellowish brown (10YR 5/4) loamy sand; weak coarse prismatic; very friable; few fine roots; gradual smooth.

E2 $42-59 \mathrm{~cm}$; light yellowish brown (10YR 6/4) loamy sand; weak coarse prismatic; very friable; few fine and medium roots; clear smooth.

Bt $\quad 59-110 \mathrm{~cm}$; strong brown (7.5YR 4/6) sandy clay loam; weak medium prismatic; firm. 



\section{Appendix B}

\section{Magnetic Sediment Susceptibility Testing}




\section{Introduction}

The magnetic susceptibility (MS) of a given sediment sample can be thought of as a measure of how easily that sample can be magnetized (Dearing 1999; Gose and Nickels 2001[1998]). At low magnetic field strengths, this measure is primarily related to the concentration and grain size of ferro and ferromagnetic minerals in the sample (Gose and Nickels 2001[1998]). A number of processes can result in an increase in MS values in a sediment sample. Of these processes, those that are of concern here are related to an increase in the organic constitutes or changes in the mineralogy of sediments in a given sample (see Collins et al. 1994; McClean and Kean 1993; Singer and Fine 1989). Sediments with higher organic content tend to have higher magnetic susceptibility values, probably as a result of the production of maghemite, an iron oxide, during organic decay (Reynolds and King 1995). Pedogenic processes, such as soil formation and weathering, can result in the concentration of organic material, as well as alterations in the mineralogy of a given zone. These processes can significantly impact susceptibility readings. Cultural processes, such as the concentration of ash, charcoal, and refuse, would also produce higher MS readings. A measure of the magnetic susceptibility of a sediment sample, then, may provide information on both the presence of surfaces, as well as a measure of the concentration of cultural activity upon those surfaces.

\section{Collection Procedures and Laboratory Methods}

A total of 57 samples were collected for magnetic sediment susceptibility from nine sites (41LR-164, 168, 170, 186, 187, 208, 260, 268, and 286) at Camp Maxey. All samples were collected at $10-\mathrm{cm}$ intervals along a given vertical stretch of an excavation unit. All sediment samples were air dried on a non-metal surface. After drying, the samples were then ground to a uniform grain size using a ceramic mortar and pestle. This was done to standardize particle size and make the material both easier to handle and pack into sample containers. After each sample was ground, the mortar and pestle was washed with tap water and wiped dry with a paper towel to avoid cross-sample contamination. The ground sample was then poured into a sample container consisting of a plastic cube with external dimensions of $2.54 \times 2.54 \times 1.94 \mathrm{~cm}$. The cubes have an average weight of 4.85 grams. The sediment filled cube was then weighed, and the weight of the sample calculated by subtracting the empty cube weight. This was done to correct for differences in mass. Assuming that sample volume and material is constant, larger samples should have higher susceptibility values simply as a function of greater mass

The cube was then placed into a MS2B Dual Frequency Sensor that, in conjunction with a MS2 Magnetic Susceptibility Meter, provided a measure of the magnetic susceptibility of the sample (see Dearing 1999). For each cube, three distinct readings were taken using the SI (standard international) scale. These readings were then averaged to provide a single measure. The value, referred to as volume specific susceptibility and noted with the symbol $\mathcal{K}$ (Kappa), is recorded on a scale of $10^{-5}$, though there are no units associated with the value. That is, the value is dimensionless (Dearing 1999).

In order to correct for differences in sample weight, and provide units to the value $\mathcal{K}$, the mass specific susceptibility value $\left(\chi_{0}\right)$ was calculated using the formula,

$$
\chi_{0}=\left(\mathcal{K}_{0} / \mathrm{p}\right)
$$

where $\mathrm{p}$ is the sample bulk density expressed in $\mathrm{kg} \mathrm{m}^{-3}$. The bulk density is determined by dividing the sample mass by volume. However, as all samples were measured in identical cubes, and all cubes were full, the sample volume is assumed to be constant. Only the mass of the sample varied. Mass specific susceptibility can be determined by,

$$
\chi_{0}=\left(\mathcal{K}_{*} * \text { calibrated mass }\right) / \text { sample mass }
$$

where sample mass is determined by subtracting the cube weight from the total sample weight (Dearing 1999). Calibrated mass is assumed to be 10 grams.

While the resulting values now have both a scale and associated units, the critical element for the current discussion is related to relative differences between $\chi_{\text {s sample values within a given profile or site, rather }}$ 
than absolute differences. That is, the principal interest is in rapid changes in the mass specific susceptibility values along a profile. This change may signal either a buried surface and/or cultural activity at that location. Comparisons of absolute values between samples from different areas, especially when the parent material of the soils is different, are of limited utility given our current goals.

This can be seen in Table B-1, which lists a variety of examples of mass specific susceptibility values for several different materials. In all cases, the analysis was performed following the procedures outlined previously. Note that the values differ widely, from a low of -1.47 for tap water, to a high of 97.62 for sediments collected from a burned rock midden. Samples 5 and 6 are of two different clays from the same general setting, far northern Lamar County in north Texas. The mass specific susceptibility is different for these samples, probably as a function of different frequencies of trace elements that, though small in absolute quantity, can dramatically impact the susceptibility values.

The potential impacts of cultural processes on susceptibility values can be seen by considering a data set collected from an archaeological site located in Brown County, 41BR473. A total of 279 sediment susceptibility samples were collected from each level of over 50 shovel tests placed at this site. In all cases, the analytical procedures followed those outlined previously. Table B-2 presents summary data on all 279 cases, along with susceptibility scores for those settings that had fire-cracked rock (FCR) or chipped stone present. If cultural inputs result in higher susceptibility values, then it should be the case that significantly higher susceptibility values will be present in levels that have cultural material.

Table B-1. Magnetic sediment susceptibility data for a variety of substances

\begin{tabular}{|l|c|c|c|c|c|c|c|}
\hline \multicolumn{1}{|c|}{ Sample Type } & $\begin{array}{c}\text { Total } \\
\text { Wt. (gr.) }\end{array}$ & $\begin{array}{c}\text { Sample } \\
\text { Wt. (gr.) }\end{array}$ & $\begin{array}{c}\text { Reading } \\
\mathbf{1}(\mathbf{k})\end{array}$ & $\begin{array}{c}\text { Reading } \\
\mathbf{2}(\mathbf{k})\end{array}$ & $\begin{array}{c}\text { Reading } \\
\mathbf{3}(\mathbf{k})\end{array}$ & $\begin{array}{c}\text { Average } \\
\mathbf{K}\end{array}$ & $\begin{array}{c}\text { Corrected } \\
\text { Mass (X) }\end{array}$ \\
\hline $\begin{array}{l}\text { 1) Sandy sediment } \\
\text { with organics }\end{array}$ & 13.7 & 8.85 & 27.9 & 28 & 28.1 & 28.00 & 31.64 \\
\hline $\begin{array}{l}\text { 2) Modern mesquite } \\
\text { charcoal and sediment }\end{array}$ & 9.4 & 4.55 & 10.7 & 10.8 & 10.7 & 10.73 & 23.59 \\
\hline $\begin{array}{l}\text { 3) Modern oak } \\
\text { wood ash }\end{array}$ & 7.5 & 2.65 & 16.1 & 16.2 & 16.2 & 16.17 & 61.01 \\
\hline $\begin{array}{l}\text { 4) Sediment from } \\
\text { burned rock midden }\end{array}$ & 11.3 & 6.45 & 62.9 & 63 & 63 & 62.97 & 97.62 \\
\hline $\begin{array}{l}\text { 5) Grey clay - no } \\
\text { human occupation }\end{array}$ & 12.6 & 7.75 & 10.4 & 10.3 & 10.4 & 10.37 & 13.38 \\
\hline $\begin{array}{l}\text { 6) Red clay - no } \\
\text { human occupation }\end{array}$ & 10.8 & 5.95 & 11.9 & 12 & 12 & 11.97 & 20.11 \\
\hline 7) Sandstone & 14.7 & 9.85 & 6.9 & 7 & 7.1 & 7.00 & 7.11 \\
\hline 8) Limestone & 12.7 & 7.85 & -0.5 & -0.5 & -0.5 & -0.50 & -0.64 \\
\hline 9) Tap water & 10.5 & 5.65 & -0.8 & -0.8 & -0.9 & -0.83 & -1.47 \\
\hline
\end{tabular}

Table B-2: Presence/absence of cultural material and mass specific sediment susceptibility scores for shovel tests at 41BR473

\begin{tabular}{|c|c|c|c|c|c|}
\hline & All Cases & $\begin{array}{c}\text { FCR } \\
\text { Present }\end{array}$ & $\begin{array}{c}\text { FCR } \\
\text { Absent }\end{array}$ & $\begin{array}{c}\text { Chipped Stone } \\
\text { Present }\end{array}$ & $\begin{array}{c}\text { Chipped Stone } \\
\text { Absent }\end{array}$ \\
\hline $\begin{array}{c}\text { Number } \\
\text { of Samples }\end{array}$ & 279 & 84 & 195 & 38 & 241 \\
\hline Mean Value & 48.3 & 56.9 & 44.6 & 55.2 & 47.2 \\
\hline $\begin{array}{c}\text { Standard } \\
\text { Deviation }\end{array}$ & 17.2 & 17.7 & 15.6 & 16.1 & 17.1 \\
\hline
\end{tabular}


An examination of Table B-2 will demonstrate that this is indeed the case. Levels that have FCR present do have higher scores relative to those that lack FCR. Similarly, those levels that have chipped stone present have a higher average mass specific susceptibility score relative to those that lack chipped stone. As the distribution is approximately normal, a t-test was used to test the overall significance of these differences. In both the FCR and chipped stone comparisons, the test confirms that those levels with cultural material have significantly higher scores than those without cultural material (FCR t-statistic $=5.804, \mathrm{df}=277, \mathrm{p}<.001$; Chipped stone t-statistic $=2.674, \mathrm{df}=277, \mathrm{p}=.008$ ). Our preliminary investigations, then, coupled with the previous work, clearly suggest that an analysis of the magnetic susceptibility of sediment can provide additional information on both the presence of buried surfaces, as well as the impact of cultural material on those surfaces.

\section{Results}

Table B-3 presents the results of the susceptibility analysis of the 57 samples, along with provenience information. The results are summarized by site.

Table B-3. Sediment susceptibility data for Camp Maxey testing

\begin{tabular}{|c|c|c|c|c|c|c|c|c|c|}
\hline 41LR & $\begin{array}{c}\text { Excavation } \\
\text { Unit }\end{array}$ & Depth & $\begin{array}{c}\text { Total } \\
\text { Weight }\end{array}$ & $\begin{array}{c}\text { Reading } \\
1\end{array}$ & $\begin{array}{c}\text { Reading } \\
2\end{array}$ & $\begin{array}{c}\text { Reading } \\
\mathbf{3} \\
\end{array}$ & $\begin{array}{l}\text { Average } \\
\text { Reading }\end{array}$ & $\begin{array}{c}\text { Corrected } \\
\text { Weight }\end{array}$ & $\begin{array}{c}\text { Mass- } \\
\text { Specific } \\
\text { Value } \\
\end{array}$ \\
\hline 260 & $\mathrm{XU} 2$ & 5 & 12.7 & 16.3 & 16.4 & 16.4 & 16.37 & 7.85 & 20.85 \\
\hline 260 & XU 2 & 15 & 13.4 & 18.3 & 18.4 & 18.5 & 18.40 & 8.55 & 21.52 \\
\hline 260 & XU 2 & 25 & 14.1 & 22.8 & 22.9 & 22.9 & 22.87 & 9.25 & 24.72 \\
\hline 260 & XU 2 & 35 & 13.9 & 20.7 & 20.6 & 20.7 & 20.67 & 9.05 & 22.84 \\
\hline 260 & XU 2 & 45 & 14.6 & 23.3 & 23.3 & 23.4 & 23.33 & 9.75 & 23.93 \\
\hline 260 & XU 2 & 55 & 14.8 & 23.6 & 23.4 & 23.5 & 23.50 & 9.95 & 23.62 \\
\hline 260 & XU 2 & 65 & 14.9 & 22 & 22.1 & 22.1 & 22.07 & 10.05 & 21.96 \\
\hline 260 & XU 2 & 75 & 14.2 & 19.7 & 19.7 & 19.7 & 19.70 & 9.35 & 21.07 \\
\hline 168 & XU 1 & 5 & 12.7 & 63.2 & 63.3 & 62.8 & 63.10 & 7.85 & 80.38 \\
\hline 168 & XU 1 & 15 & 15.2 & 56.8 & 56.9 & 57 & 56.90 & 10.35 & 54.98 \\
\hline 168 & XU 1 & 25 & 15.7 & 52.6 & 52.6 & 52.7 & 52.63 & 10.85 & 48.51 \\
\hline 168 & XU 1 & 35 & 14.1 & 65.5 & 65.5 & 65.5 & 65.50 & 9.25 & 70.81 \\
\hline 187 & XU 1 & 5 & 13.4 & 23.4 & 23.6 & 23.7 & 23.57 & 8.55 & 27.56 \\
\hline 187 & XU 1 & 15 & 13.7 & 22.4 & 22.3 & 22.3 & 22.33 & 8.85 & 25.24 \\
\hline 187 & XU 1 & 25 & 14.4 & 22.4 & 22.3 & 22.3 & 22.33 & 9.55 & 23.39 \\
\hline 187 & XU 1 & 35 & 15.2 & 21.8 & 21.7 & 21.8 & 21.77 & 10.35 & 21.03 \\
\hline 187 & XU 1 & 45 & 15.1 & 18.1 & 18.1 & 18.1 & 18.10 & 10.25 & 17.66 \\
\hline 187 & XU 1 & 55 & 15.2 & 25.4 & 25.4 & 25.5 & 25.43 & 10.35 & 24.57 \\
\hline 187 & XU 1 & 65 & 15.2 & 25.4 & 25.4 & 25.4 & 25.40 & 10.35 & 24.54 \\
\hline 187 & XU 1 & 75 & 14.6 & 38 & 38.1 & 38 & 38.03 & 9.75 & 39.01 \\
\hline 186 & XU 2 & 5 & 13.5 & 12.8 & 12.8 & 12.9 & 12.83 & 8.65 & 14.84 \\
\hline 186 & XU 2 & 15 & 14.1 & 13.9 & 14.1 & 14 & 14.00 & 9.25 & 15.14 \\
\hline 186 & XU 2 & 25 & 14.1 & 14 & 14.1 & 14.1 & 14.07 & 9.25 & 15.21 \\
\hline 186 & XU 2 & 35 & 15.5 & 15.2 & 15.3 & 15.3 & 15.27 & 10.65 & 14.33 \\
\hline 186 & XU 2 & 45 & 15.3 & 16 & 15.9 & 16 & 15.97 & 10.45 & 15.28 \\
\hline 186 & XU 2 & 55 & 15.1 & 13.7 & 13.7 & 13.7 & 13.70 & 10.25 & 13.37 \\
\hline 186 & XU 2 & 65 & 15.3 & 14.6 & 14.7 & 14.7 & 14.67 & 10.45 & 14.04 \\
\hline 186 & XU 2 & 75 & 15.5 & 12 & 12.1 & 12.1 & 12.07 & 10.65 & 11.33 \\
\hline 186 & XU 2 & 85 & 14.4 & 7.6 & 7.7 & 7.8 & 7.70 & 9.55 & 8.06 \\
\hline 186 & XU 2 & 95 & 15.5 & 4.2 & 4.3 & 4.4 & 4.30 & 10.65 & 4.04 \\
\hline 268 & XU 3 & 5 & 13.7 & 21.6 & 21.7 & 21.7 & 21.67 & 8.85 & 24.48 \\
\hline 268 & XU 3 & 15 & 13.4 & 12.3 & 12.1 & 12.1 & 12.17 & 8.55 & 14.23 \\
\hline 268 & XU 3 & 25 & 14.3 & 9.7 & 9.9 & 9.7 & 9.77 & 9.45 & 10.34 \\
\hline 268 & XU 3 & 35 & 14.4 & 6.8 & 7 & 6.9 & 6.90 & 9.55 & 7.23 \\
\hline 268 & XU 3 & 45 & 13 & 10.8 & 10.9 & 10.8 & 10.83 & 8.15 & 13.29 \\
\hline
\end{tabular}


Table B-3. Continued...

\begin{tabular}{|c|c|c|c|c|c|c|c|c|c|}
\hline 41LR & $\begin{array}{c}\text { Excavation } \\
\text { Unit }\end{array}$ & Depth & $\begin{array}{c}\text { Total } \\
\text { Weight }\end{array}$ & $\begin{array}{c}\text { Reading } \\
1\end{array}$ & $\begin{array}{c}\text { Reading } \\
2\end{array}$ & $\begin{array}{c}\text { Reading } \\
3\end{array}$ & $\begin{array}{l}\text { Average } \\
\text { Reading }\end{array}$ & $\begin{array}{c}\text { Corrected } \\
\text { Weight }\end{array}$ & $\begin{array}{c}\text { Mass- } \\
\text { Specific } \\
\text { Value }\end{array}$ \\
\hline 164 & XU 1 & 5 & 14.2 & 24.9 & 25.1 & 25.2 & 25.07 & 9.35 & 26.81 \\
\hline 164 & XU 1 & 15 & 14.4 & 22.8 & 22.9 & 23.1 & 22.93 & 9.55 & 24.01 \\
\hline 164 & XU 1 & 25 & 14.9 & 186.4 & 187.8 & 188 & 187.40 & 10.05 & 186.47 \\
\hline 164 & XU 1 & 35 & 15.1 & 48.8 & 48.8 & 48.9 & 48.83 & 10.25 & 47.64 \\
\hline 164 & XU 1 & 45 & 14.7 & 33 & 33 & 32.8 & 32.93 & 9.85 & 33.43 \\
\hline 286 & XU 1 & 5 & 13 & 25.1 & 25.2 & 25.2 & 25.17 & 8.15 & 30.88 \\
\hline 286 & XU 1 & 15 & 13.8 & 37.7 & 37.8 & 37.9 & 37.80 & 8.95 & 42.23 \\
\hline 286 & XU 1 & 25 & 14.4 & 34.5 & 34.7 & 34.8 & 34.67 & 9.55 & 36.30 \\
\hline 286 & XU 1 & 35 & 14.1 & 34.4 & 34.4 & 34.3 & 34.37 & 9.25 & 37.15 \\
\hline 286 & $\mathrm{XU} 1$ & 45 & 15.1 & 94.5 & 94.9 & 96.7 & 95.37 & 10.25 & 93.04 \\
\hline 170 & XU 5 & 5 & 13.9 & 16.1 & 16.2 & 16.2 & 16.17 & 9.05 & 17.86 \\
\hline 170 & XU 5 & 15 & 13.8 & 16.5 & 16.6 & 16.6 & 16.57 & 8.95 & 18.51 \\
\hline 170 & XU 5 & 25 & 14.2 & 16.8 & 16.8 & 17 & 16.87 & 9.35 & 18.04 \\
\hline 170 & XU 5 & 35 & 14.6 & 18.5 & 18.4 & 18.5 & 18.47 & 9.75 & 18.94 \\
\hline 170 & XU 5 & 45 & 14.4 & 17.5 & 17.6 & 17.7 & 17.60 & 9.55 & 18.43 \\
\hline 170 & XU 5 & 55 & 14.3 & 16.8 & 16.9 & 16.9 & 16.87 & 9.45 & 17.85 \\
\hline 170 & XU 5 & 65 & 14.9 & 17.4 & 17.3 & 17 & 17.23 & 10.05 & 17.15 \\
\hline 208 & XU 2 & 5 & 14.5 & 376.7 & 376.8 & 382.2 & 378.57 & 9.65 & 392.30 \\
\hline 208 & XU 2 & 15 & 14.4 & 85.7 & 85.8 & 85.7 & 85.73 & 9.55 & 89.77 \\
\hline 208 & XU 2 & 25 & 14.8 & 184 & 184.6 & 184.6 & 184.40 & 9.95 & 185.33 \\
\hline 208 & XU 2 & 35 & 14 & 63.8 & 64.4 & 64.4 & 64.20 & 9.15 & 70.16 \\
\hline 208 & XU 2 & 45 & 13.7 & 53.2 & 53.3 & 52.9 & 53.13 & 8.85 & 60.04 \\
\hline
\end{tabular}

\section{LR164}

On this site, five samples were collected at $10-\mathrm{cm}$ intervals from 0 to $50 \mathrm{~cm}$ bs in XU 2. The results provided by the samples from this excavation unit indicate an increase in the mass-specific susceptibility value associated with Level 4 (30-40 cm bs). The cooccurrence of this spike in the value with the Feature 1 level for this excavation unit hints that the feature may have been associated with a buried occupation surface at this site. Note that the extremely high value in Level 3 is almost certainly indicative of ferrous particles in the soil within this level. The results for this level should be ignored.

\section{LR168}

Sediment susceptibility samples were collected from XU 1, at 10-cm intervals, from 0 to $40 \mathrm{~cm}$ bs. An examination of the values suggests that the 30-40 level had a significant increase in susceptibility, possibly indicating the presence of a buried surface. This corresponds to the bottom of the level at which the majority of artifacts were encountered at this site.

\section{LR170}

Soil susceptibility samples were collected from XU 5, from 0 to $70 \mathrm{~cm}$ bs, at $10-\mathrm{cm}$ intervals. No significant peaks were present in these values. The lack of significant increases associated with any single level suggests that, at least for the upper $70 \mathrm{~cm}$ of deposits, no buried surfaces are present. 


\section{LR186}

Sediment susceptibility samples were collected from XU 2, from 0 to $100 \mathrm{~cm}$ bs, at $10-\mathrm{cm}$ intervals. No significant peaks were noted in the values with the possible exception of a slight increase at 40 to 50 $\mathrm{cm}$ bs. This lack of any significant spike suggests that, at least in the single area tested, no buried surfaces are present.

\section{LR187}

Sediment susceptibility samples were collected from $\mathrm{XU}$ 1, from 0 to $80 \mathrm{~cm}$ bs, at $10-\mathrm{cm}$ intervals. Two possible surfaces are indicated by the values. The first is at 50 to $60 \mathrm{~cm}$ bs, while the second is at 70 to $80 \mathrm{~cm}$ bs. Both of these peaks are below the level at which artifacts are most common at site level. As such, it is unclear if these peaks are cultural or natural in origin.

\section{LR208}

Sediment susceptibility samples were collected from excavation unit 2 , from 0 to $50 \mathrm{~cm}$ bs, at $10-\mathrm{cm}$ intervals. The presence of ferrous materials in these samples in levels 1 and 3 resulted in extremely high values, and thus rendered the susceptibility column difficult to interpret. Ferrous inclusions, present in the sediments as a result of natural processes, in effect obscured any potential cultural patterning.

\section{LR260}

Sediment susceptibility samples were collected from excavation unit 2 , from 0 to $80 \mathrm{~cm}$ bs, at $10-\mathrm{cm}$ intervals. A small peak is present in these values at 20 to $30 \mathrm{~cm}$ bs. While the peak is not extreme, the correlation of this peak with an increase in site-level artifacts between 20 and $40 \mathrm{~cm}$ bs, suggests that a buried surface may be present at 41LR260.
Sediment susceptibility samples were collected from XU 3, from 0 to $50 \mathrm{~cm} \mathrm{bs,} \mathrm{at} 10-\mathrm{cm}$ intervals. No significant peaks were noted in the values with the possible exception of a slight increase at 40 to $50 \mathrm{~cm}$ bs. This lack of any significant spike suggests that, at least in the single area tested, no buried surfaces are present.

\section{LR286}

Sediment susceptibility samples were collected from XU 1 , from 0 to $50 \mathrm{~cm}$ bs, at $10-\mathrm{cm}$ intervals. Significant peaks are present at 10 to $20 \mathrm{~cm}$ bs, and at 40 to $50 \mathrm{~cm}$ bs. The 10 to $20 \mathrm{~cm}$ peak correlates with the higher artifact content reflected for the upper $20 \mathrm{~cm}$ at the site. The high value of the 40 to $50 \mathrm{~cm}$ peak may be related to small quantities of ferrous material, though the value is within the range present for sediments that have high organic and ash deposits.

\section{Summary}

While difficult to interpret, in part because of the presence of ferrous particles in the soils of Camp Maxey and in part because of the small number of samples collected from any given site, the results of the sediment susceptibility analysis generally support the patterns observed when considering density of material or the presence of features. With finer-grained sampling, and more frequent samples collected from a variety of locations within a site, higher resolution would certainly be possible for archaeological sites at Camp Maxey. 


\section{References Cited}

Collins, M. B., W. A. Gose, and S. Shaw

1994 Preliminary Geomorphological Findings at Dust and Nearby Caves. Journal of Alabama Archaeology 40:35-56.

Dearing, J.

1999 Environmental Magnetic Susceptibility. Chi Publishing, Kenilworth, England.

Gose, W. A., and D. L. Nickels

2001[1998] Archaeomagnetic and Magnetic Susceptibility Analyses. In Test Excavations at the Culebra Creek Site, 41BX126, Bexar County, Texas, by D. L. Nickels, C. B. Bousman, J. D. Leach, and D. A. Cargill, pp. 204-214. Archaeological Survey Report, No. 265, Center for Archaeological Research, The University of Texas at San Antonio; Archeology Studies Program, Report 3, Environmental Affairs Division, Texas Department of Transportation, Austin.

McClean, R. G., and W. F. Kean

1993 Contributions of Wood Ash Magnetism to Archeomagnetic Properties of Fire Pits and Hearths. Earth and Planetary Science Letters 119:387-394.

Reynolds, R. L., and J. W. King

1995 Magnetic Records of Climate Change. U.S. National Report to I.U.G.G., 1991-1994. American Geophysical Union. <http://www.agu.ong/revgeophys/reyno100/reyno100.html> Accessed April 2001.

Singer, M. J., and P. Fine

1998 Pedogenic Factors Affecting Magnetic Susceptibility of Northern California Soils. Soil Science of America Journal 53:1119-1127. 


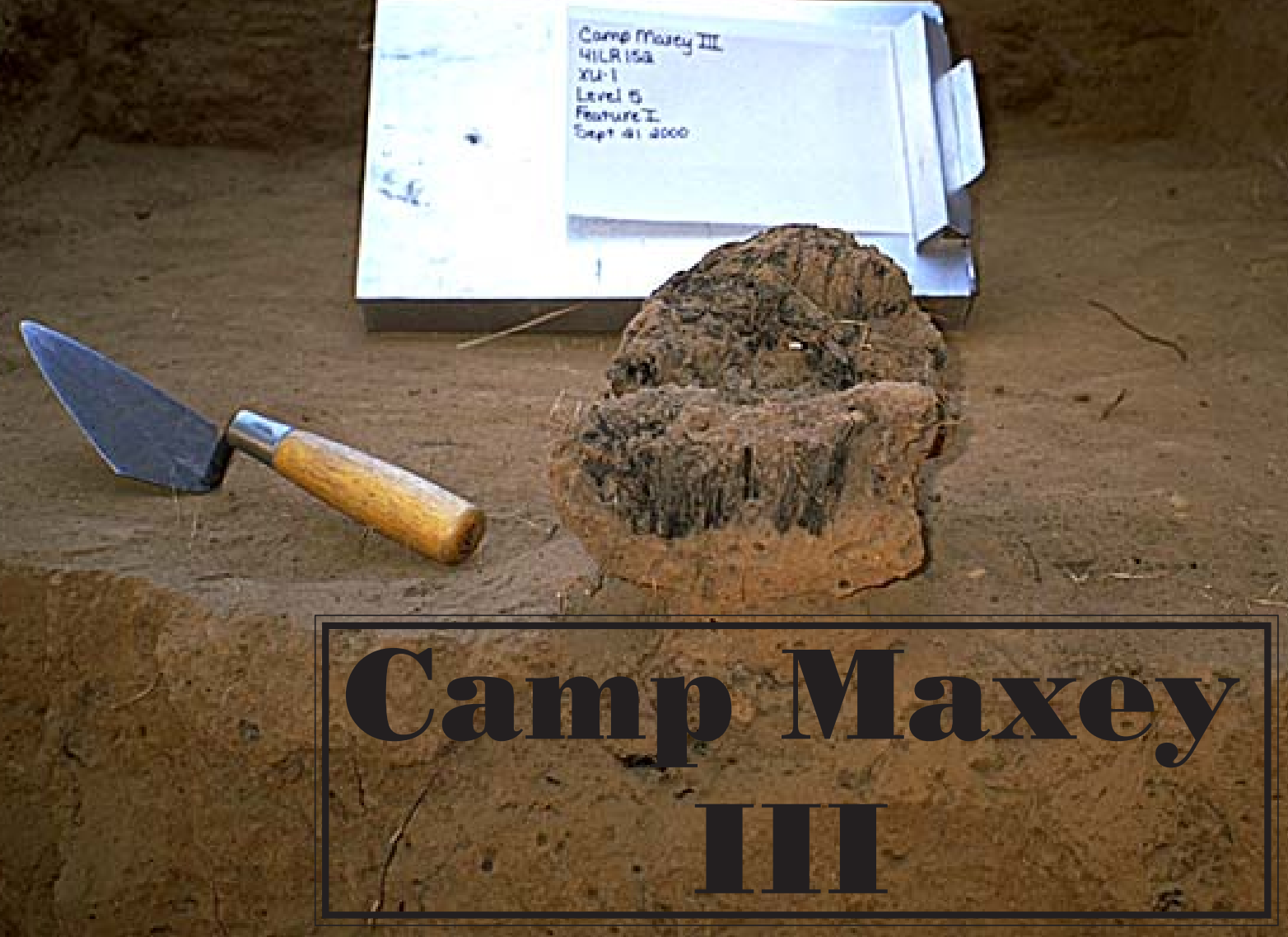

\section{Archaeological Testing of 23 Prehistoric Sites, Lamar County, Texas}

\section{Map Supplement}

by

Richard B. Mahoney

with contributions by

Corey A. Crawford, Raymond P. Mauldin, Lee C. Nordt, Timothy K. Perttula, and Sylvia Reyna

Center for Archaeological Research The University of Texas at San Antonio Archaeological Survey Report, No. 314 2001

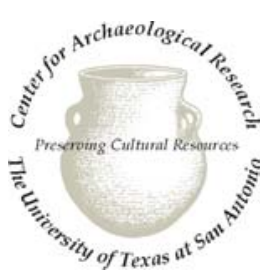




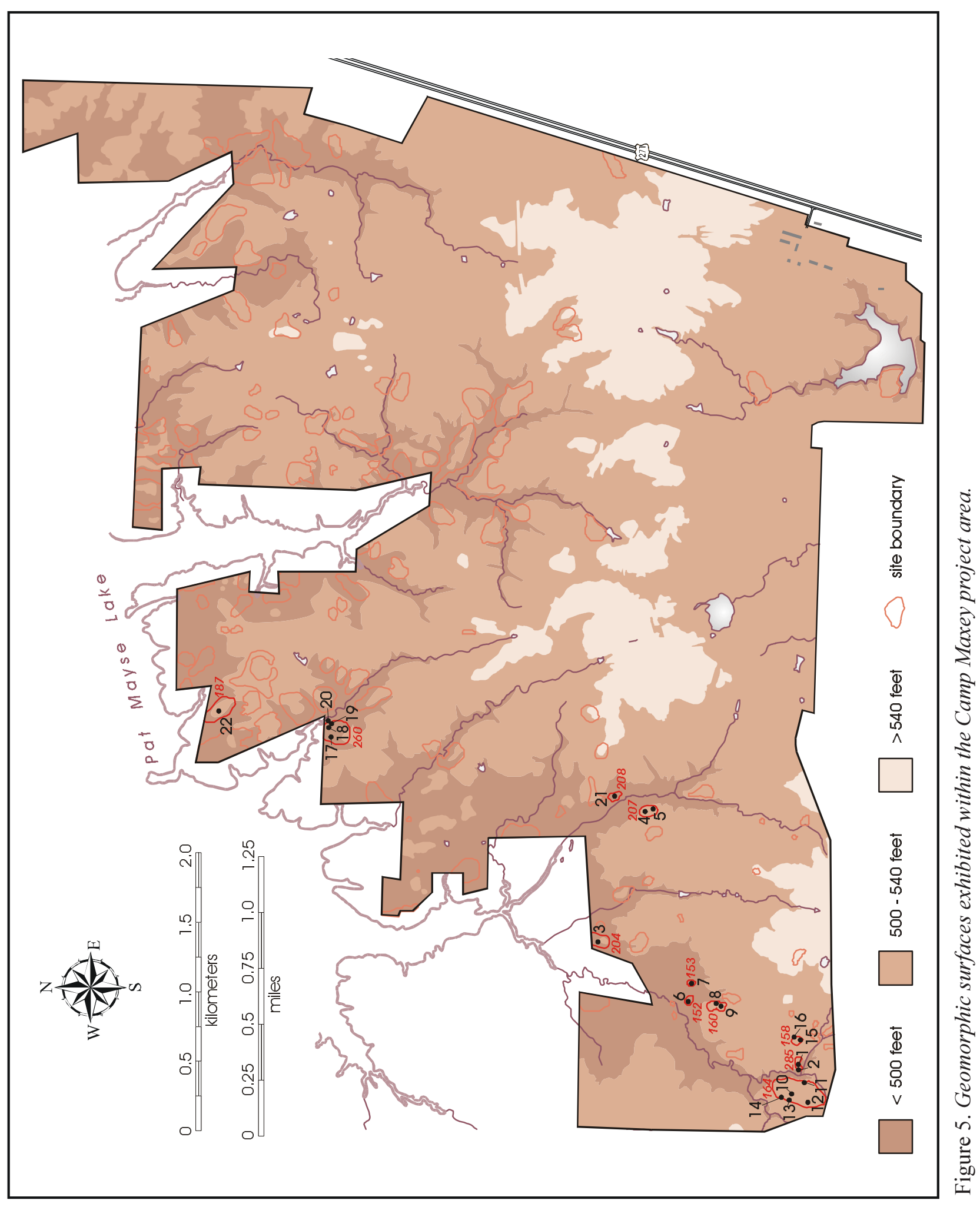

\section{Camp Maxey III:}

Archaeological Testing of 23 Prehistoric Sites, Lamar County, Texas ASR No. 314, Center for Archaeological Research, The University of Texas at San Antonio, 2001 


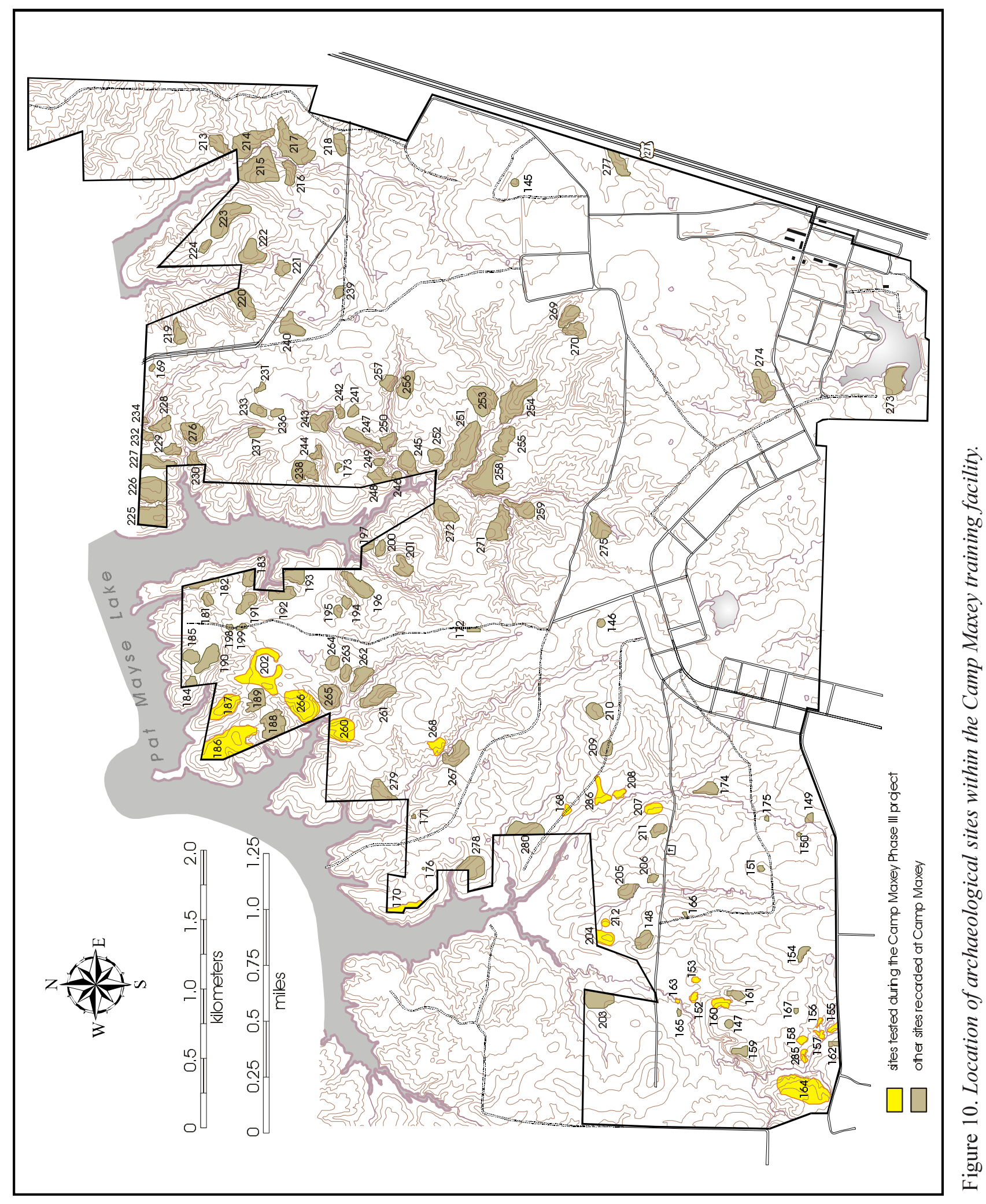

\section{Camp Maxey III:}

Archaeological Testing of 23 Prehistoric Sites, Lamar County, Texas

ASR No. 314, Center for Archaeological Research, The University of Texas at San Antonio, 2001 


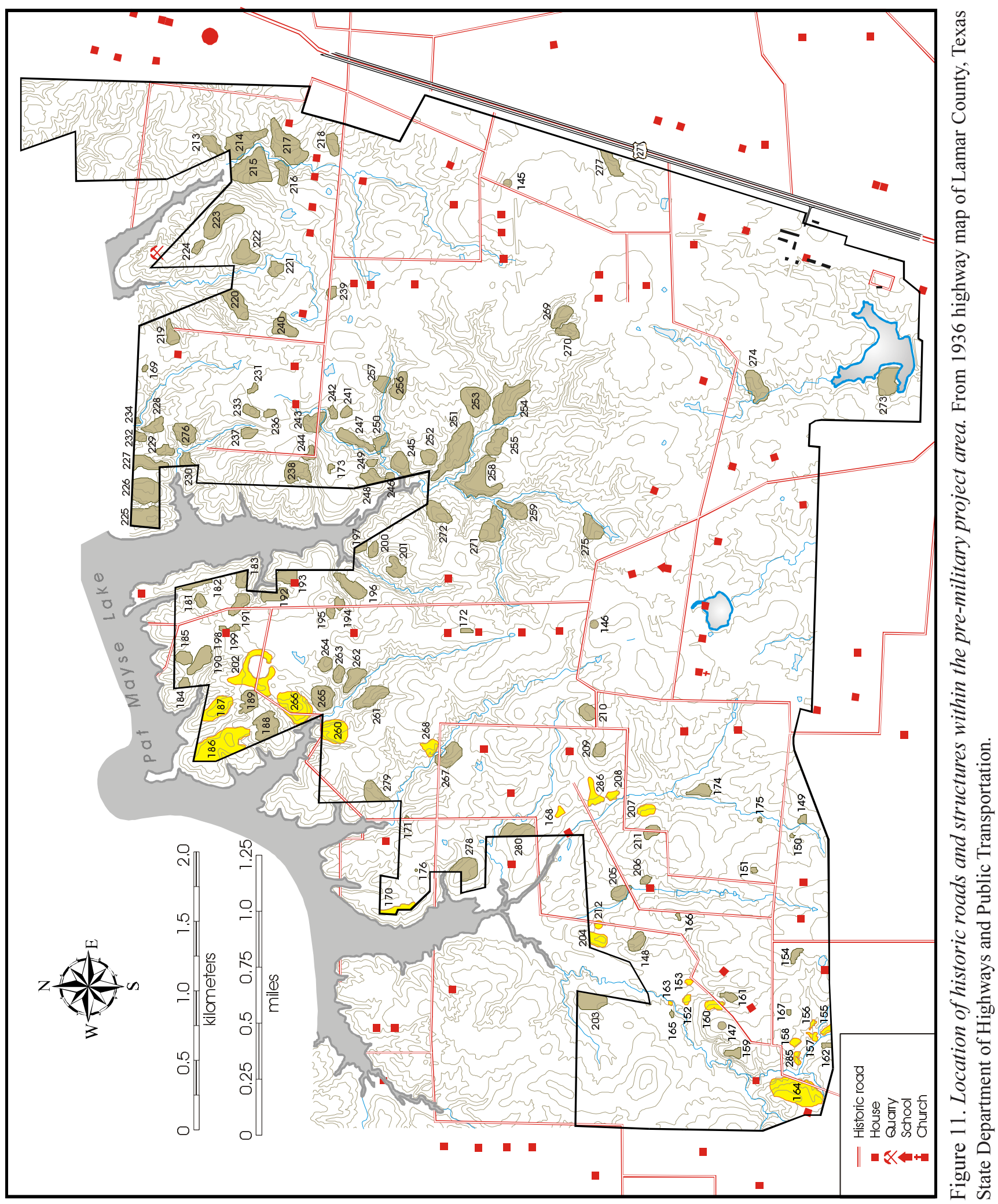

\section{Camp Maxey III:}

Archaeological Testing of 23 Prehistoric Sites, Lamar County, Texas ASR No. 314, Center for Archaeological Research, The University of Texas at San Antonio, 2001 


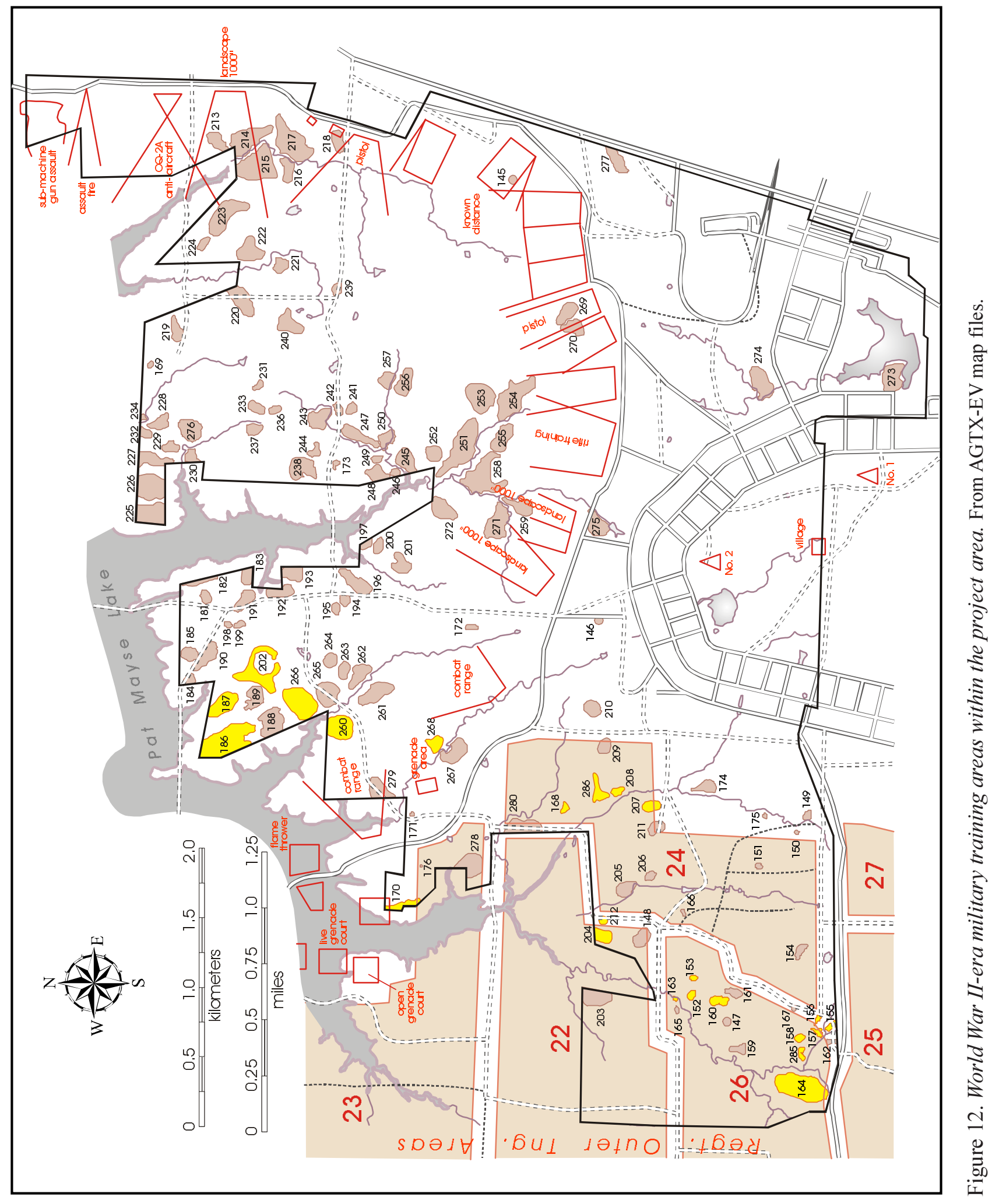

Camp Maxey III:

Archaeological Testing of 23 Prehistoric Sites, Lamar County, Texas ASR No. 314, Center for Archaeological Research, The University of Texas at San Antonio, 2001 


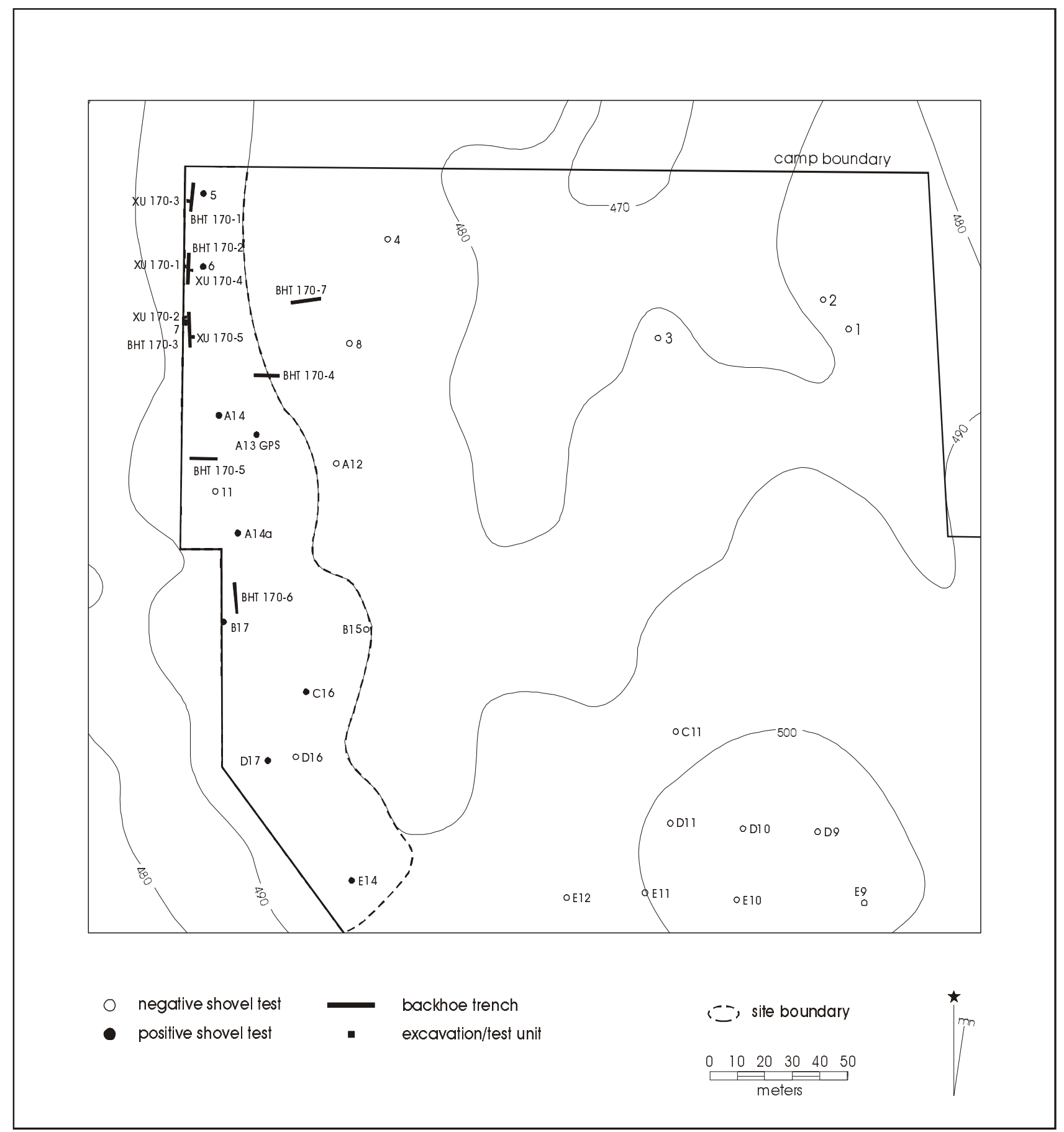

Figure 28. Site map - 41LR170.

\section{Camp Maxey III:}

Archaeological Testing of 23 Prehistoric Sites, Lamar County, Texas

ASR No. 314, Center for Archaeological Research, The University of Texas at San Antonio, 2001 

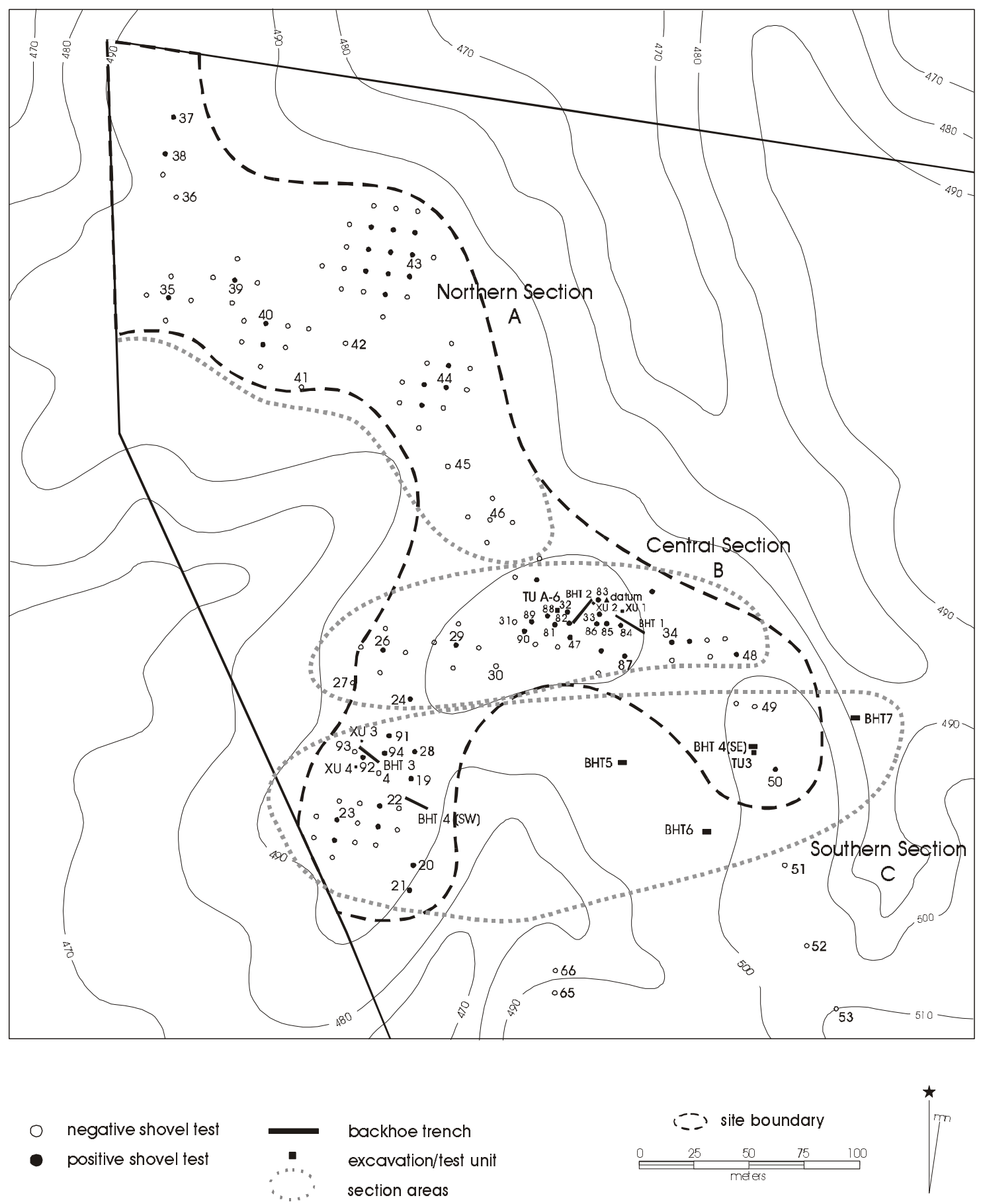

Figure 29. Site map - 41LR186.

\section{Camp Maxey III:}

Archaeological Testing of 23 Prehistoric Sites, Lamar County, Texas

ASR No. 314, Center for Archaeological Research, The University of Texas at San Antonio, 2001 

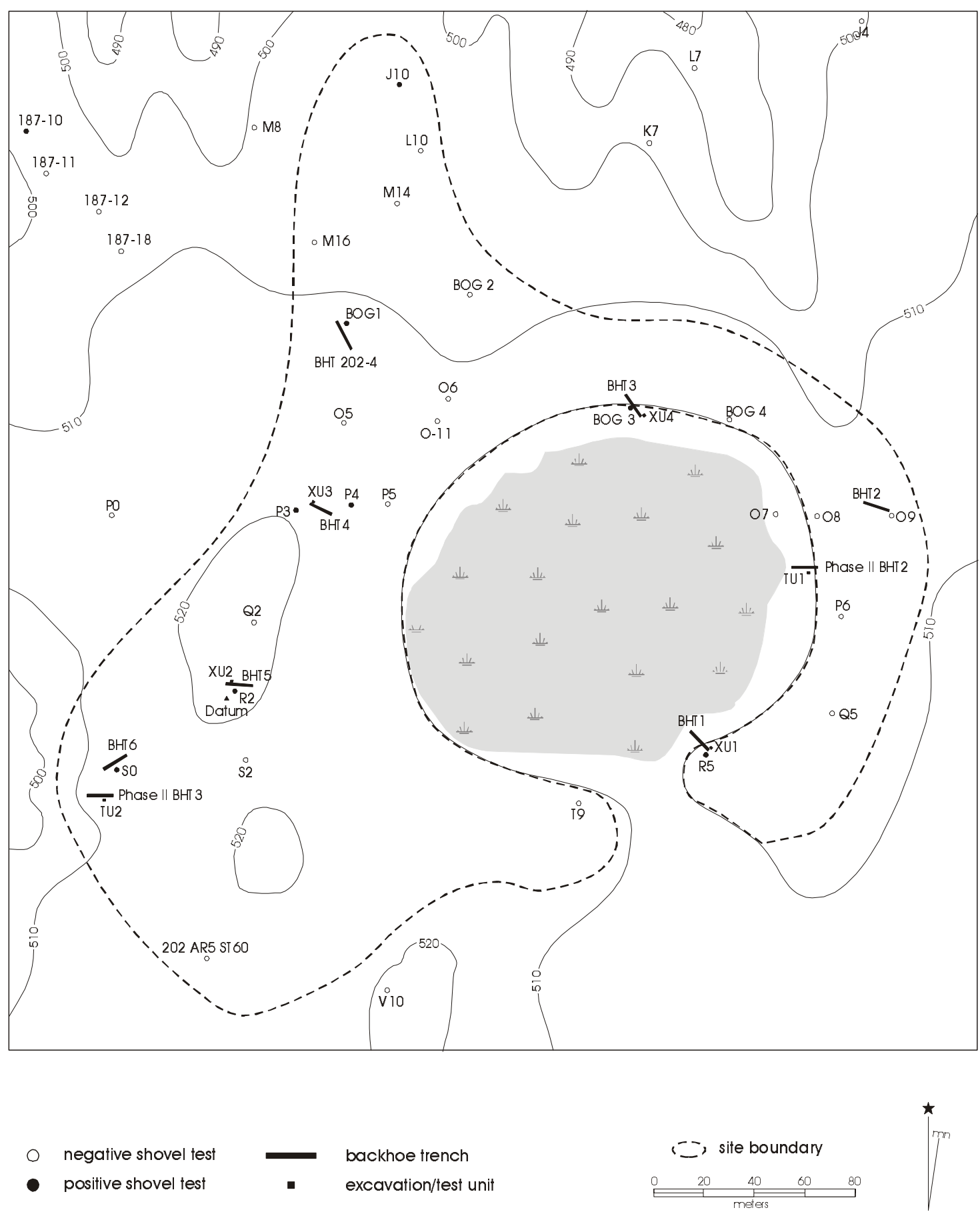

Figure 34. Site map - 41LR202.

\section{Camp Maxey III:}

Archaeological Testing of 23 Prehistoric Sites, Lamar County, Texas ASR No. 314, Center for Archaeological Research, The University of Texas at San Antonio, 2001 